\title{
Egotizam pamćenja
}

\section{Apstrakt}

Autobiografska sećanja često ne predstavljaju veran zapis prošlih događaja, već njihovu rekonstrukciju. U tom procesu, događaji bivaju modifikovani tako da se uklapaju u sliku o sebi; to uglavnom znači da se sistematski pozitivno menjaju. Ovaj fenomen zovemo egotizmom pamćenja. Serija od šest ogleda osmišljena je da se proveri a. da li ljudi sistematski precenjuju sopstvena postignuća i postignuća grupa kojima pripadaju i b. koji faktori podstiču ovu vrstu precenjivanja. Pored toga, istraživali smo da li postoje psihički korelati sklonosti ka precenjivanju prošlih postignuća, pošavši od pretpostavke da su tome skloni bolje adaptirani pojedinci.

U istraživanju je ukupno učestvovalo 558 ispitanika, prosečnog uzrasta 20 godina, slučajnim izborom raspoređenih u eksperimentalne grupe. Ispitanici su izveštavali o svojim prošlim postignućima: o uspehu u srednjoj školi ili na prijemnom ispitu za fakultet (Eksperiment 1), o percentilnom rangu koji im je saopšten nakon što su elektronski popunjavali testove različitog sadržaja (Eksperiment 2 i 3), o ukupnom procentu uspešno rešenih zadataka nakon što su dobijali informaciju o tačnosti nakon svakog pojedinačnog zadatka (Eksperiment $4.1 \mathrm{i}$ 4.2), o atributima i postignućima svoje i tuđe etničke grupe nakon čitanja novinskog članka (Eksperiment 5).

Rezultati ukazuju na to da je većina ljudi sklona precenjivanju sopstvenih postignuća (u proseku između 60\% i 80\% ispitanika), ali skor o kome izveštavaju u proseku nije substancijalno veći od onog koji im je saopšten (novi skor je u proseku 10\%-15\% viši od inicijalnog). Precenjivanje je izraženije ukoliko je a. događaj nedostupniji u memoriji (ako je proteklo više vremena od kada se desio), b. ako se o njemu izveštava u javnoj, a ne u privatnoj situaciji i c. ako je u pitanju neuspeh a ne uspeh. Iako su nekim ogledima utvrđene niske ali značajne povezanosti greške preterivanja i opšteg životnog optimizma, akademskih ambicija i pozitivnosti dominantnog afekta, ove povezanosti nisu bile dovoljno izražene i dosledne da bi se moglo zaključiti da su grešci preterivanja skloniji psihološki bolje adaptirani pojedinci.

Rezultati su diskutovani sa stanovišta odnosa motivacije i kognicije, i ukazano je na njihove praktične implikacije.

Ključne reči: egotizam, pristrasnosti u pamćenju, samoosnaživanje, precenjivanje sopstvenih postignuća, adaptivnost pristrasnosti 


\section{Memory egotism}

\section{Abstract}

Memory is not a verbatim record of past events. In fact, it is usually reconstruction, not reproduction of the past (Bartlet, 1932). Memory distortion is defined as a systematic change of the retrieved content (Bahrick et al., 2008). This change often reflects motive for selfenhancement. Unlike memories of physical objects, beliefs and memories about the self have a tendency to drift upward. Positive biases are evident in various forms of self-reports: academic performance or performance on tests of intelligence, athleticism and driving (Wilard \& Gramzow, 2009). These positive biases in autobiographic memory are often dubbed memory egotism. There are two broad contexts in which people demonstrate memory egotism (Dunning et al., 2004): (a) information deficiency: as information becomes less accessible in memory, people tend to rely on more general beliefs about themselves and reconstruct the specific information based on it (people usually hold positive self views that barring access to their actual score - bias estimates upward) and (b) self-enhancement motivation: when they are more motivated to hold a positive perception of themselves in a particular domain. Can memory egotism in a form of exaggeration of past performances be psychologically adaptive? There are evidence that well-adjusted people tend to be biased and maladjusted are often more accurate in their self-assessments (Taylor \& Brown, 1988; Taylor et al., 2003).

Based on this empirical evidence, we formulated following research hypotheses: (a) People will exaggerate in reporting of their past performances; (b) They will exaggerate more if the information is less accessible in memory (the event they are reporting is older), more in a public than in a private situation, more if the attribute that is measured is central then if it is peripheral to their self-view, more if they scored low (failure) than if they scored high (success) in comparison to a particular referent group, more in case they memorize their own performance and less if they memorize a partner's performance; (c) However, memory egotism will not be reserved solely for personal performances, but for performance of ingroup in comparison to out-group. (d) Exaggeration index will be positively correlated with: self-esteem, positive dominant affect, academic aspirations and global life-optimism.

We conducted one field experiment and five laboratory experiments in order to test these hypotheses. A total of 558 participants (Belgrade University students and students of final year in one Belgrade high school) took part in the survey. They were all randomized across experimental conditions. In the first phase of all experiments, participants provided selfreports on self-esteem, dominant affect, academic aspirations, and life-optimism. Second 
phase differed for all experiments. In a field experiment, we asked 105 freshmen and senior students to report their high school grades (mean grade ranking 2-5) and rank on entry exam for the university, with different instructions (one group "Please report as accurately as possible", other group "If you cannot remember, please provide your best estimate"). Then we matched the reported grades with the real grades from University database. Two laboratory experiments were designed to test the effects of three two-leveled factors $(2 \times 2 \times 2)$ : memory accessibility: immediate or delayed recall (after 7-10 days) and reporting situation: public or private. In one experiment the third factor was ego-involvement (reporting about performance on test that is central or peripheral for their global self-view), whilst in the other experiment, it was performance level (feedback of success or failure in test performing). Participants took computer-based tests and were informed about their performance in form of percentile rank. A total of 137 university students took part in second, and 167 took part in third experiment. Two one factor laboratory experiments were designed to test if people tend to exaggerate more when they are reconstructing their own score or when they are reconstructing the score of another person. Forty university students were respondents in experiment 4.1 and 46 senior high school students were respondents in experiment 4.2. Finally, one experiment was designed to test if people exaggerate more if they reconstruct the attributes and performance of their own group in comparison to out-group. Sixty-three senior high school students were provided with an article describing Serbian and Romanian adolescents and their alleged scores on different intellectual ability tests, and asked to report on the facts from the article.

Results across experiments showed that on average between $60 \%$ and $80 \%$ of all respondents exaggerated their scores. However, the exaggeration margin was on average around $10 \%$ of their initial grade. Respondents exaggerated more if the event was less accessible in memory (senior students more then junior when reporting their high school grades or points at the entry exam; groups tested later more then immediately tested groups). They exaggerated more if their score was low (below 50 percentile rank) then if it was high (above 85 percentile rank). There was no significant difference in exaggeration rate depending on the ego involvement, i.e. importance of attribute measured for self-image (intelligence vs. visual ability). The actors tended to over-report, while the observers tended to under-report scores on visual ability test (in one experiment) and general knowledge test (in another similar experiment). The actors were, however, more accurate in their reports than observers. Memory egotism was observed in reporting not only personal, but for also in-group performances (groups that are ego-marked, such as in-groups and/or referent groups). 
Respondents recalled more positive attributes for in-group in comparison to out-group, and they over-reported the performance score for in-group, but not those for out-group. In some experiments, there were significant, but low correlations between exaggeration score and life optimism, academic aspirations and dominant affect. These correlations, however, were not observed regularly and therefore did not allow us to conclude that better psychologically adjusted persons are more prone to self-enhancement memory biases.

Overall, majority of people tend to over-report their scores, but the exaggeration rate remains in the acceptable margins, probably due to reality constraints (it seems that gist of the event needs to be preserved) (as in Kunda, 1990). People tend to over-report motivated by selfpresentation (more in public then in private situations), but not only by self-presentation (they still significantly over-report in private, anonymous situations). Self-protective motive is stronger then self-affirmation motive (over-reporting is higher in the case of failure then in the case of success) (as in Sedikides \& Green, 2004) Accessibility in memory provokes more over-reporting. Later reports are not only less accurate, but more positively biased. It might be because reconstruction of the specific facts is based on the global self-image, especially in the domain of abilities, which is dominantly positive in majority of people (as in Kruger \& Dunning, 1999). Therefore, two plausible explanations for the observed effects can still be proposed: a. people deliberately exaggerate when reporting their test scores, and even anonymous situation provokes self-presentation motive (deception), or b. people reconstruct their memories of the event so that they fit better in their self-image (self-deception). The results are discussed in fuzzy trace memory theory framework. As a final conclusion, it can be said that memory egotism in form of past performance exaggeration is more a norm then it is a deviation, but its' scope is constrained by reality.

Keywords: egotism, memory biases, self-enhancement, exaggeration of past performances, adaptive biases 


\section{Zahvalnice}

Podršku realizaciji ovog istraživanja dalo je Ministarstvo nauke republike Srbije u okviru projekta "Identifikacija, merenje i razvoj kognitivnih i emocionalnih kompetencija važnih društvu orijentisanom na evropske integracije".

Zahvaljujem se mentoru Draganu Popadiću koji me je ohrabrivao da istražujem nove oblasti i uvek postavljao suštinska pitanja. Zahvaljujem se Gregu Vilardu i Ričardu Gramzovu na korisnim sugestijama u vezi sa dizajnom eksperimenata i analizom rezultata. Studentkinje Anja Ivanović i Marija Branković puno su mi pomogle u dizajniranju materijala za eksperimente i prikupljanju podataka. Zahvalnost dugujem i kolegama i koleginicama Aleksandru Dimitrijeviću, Vasiliju Gvozdenoviću Jasni Milošević, Sofiji Stefanović, Ivani Kovačević i Jeleni Zulević koji su mi pomogli da dođem do potrebnog broja ispitanika za probna i završna ispitivanja. Hvala i sekretarici odeljenja za psihologiju, Kaji Damnjanović, koja mi je pomogla oko organizacije eksperimenata. Zahvaljujem se ostalim članovima komisije koji su svojim sugestijama pomogli da se tekst koji je pred vama značajno unapredi. 


\section{Sadržaj}

I Uvod

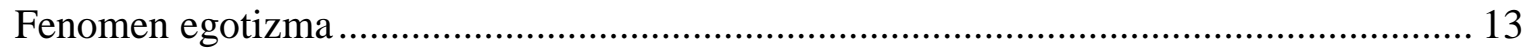

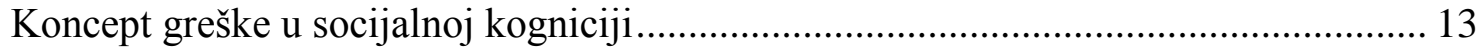

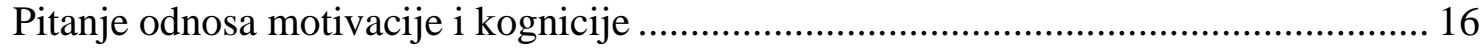

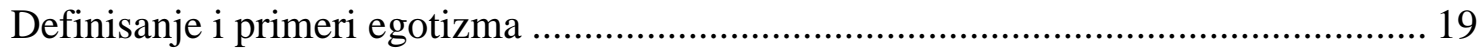

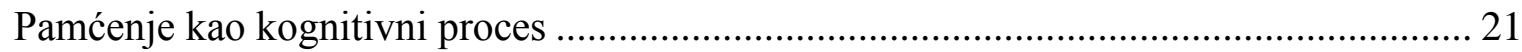

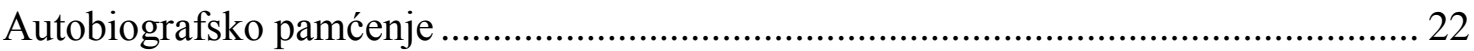

Istorijski pregled istraživanja autobiografskog pamćenja ...................................... 25

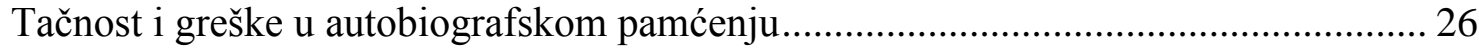

Tehnike za proveravanje tačnosti retrospektivnih izveštaja ..................................... 32

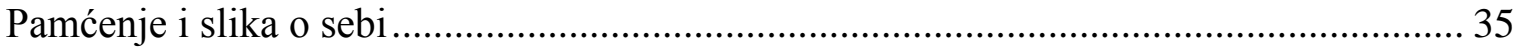

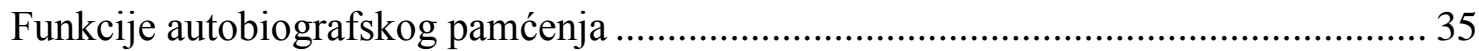

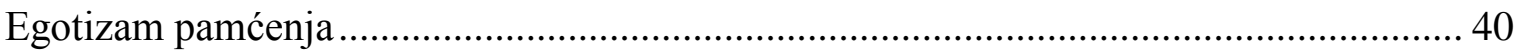

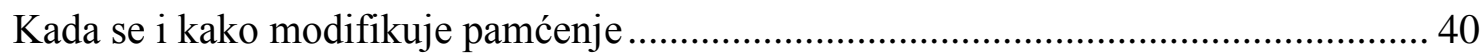

Kako pristrasnosti u pamćenju služe ličnim ciljevima ............................................... 42

Zašto dolazi do pristrasnosti u autobiografskom pamćenju? ....................................... 49

Da li je pristrasno pamćenje vrsta socijalne kognicije? ............................................ 55

Da li je tendencija ka samoprecenjivanju putem prekrajanja sećanja

obmanjivanje ili samoobmanjivanje?

Motivi za samopredstavljanjem/samoprecenjivanjem

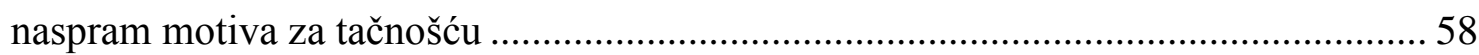

Značaj ispitivanja memorijskih pristrasnosti i uloge motivacije u prisećanju .................... 60

Da li pristrasnosti u samospoznaji mogu biti funkcionalne za pojedinca? ........................ 64

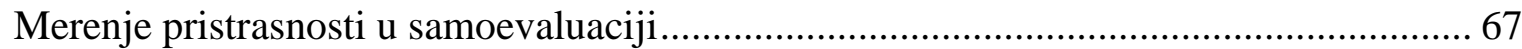

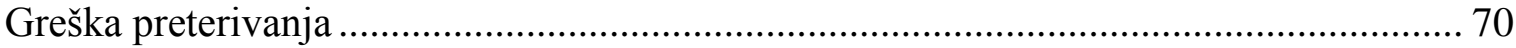

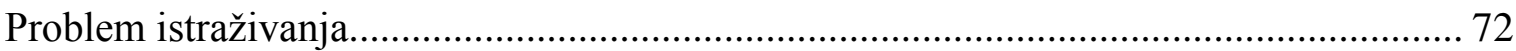

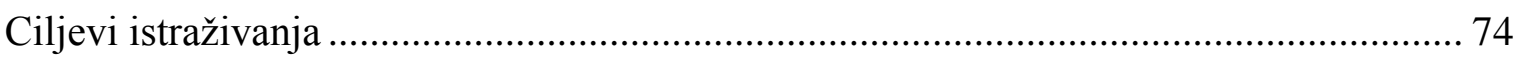

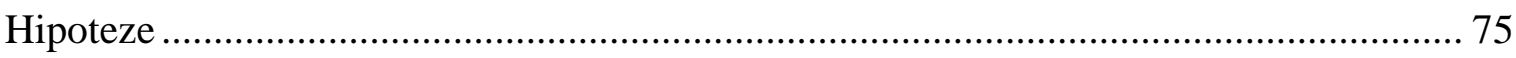

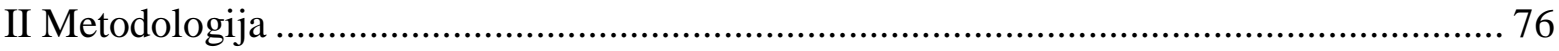

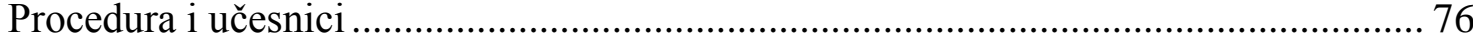

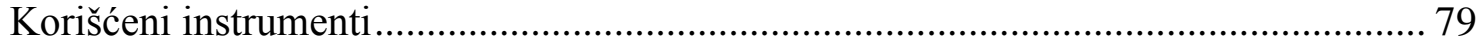




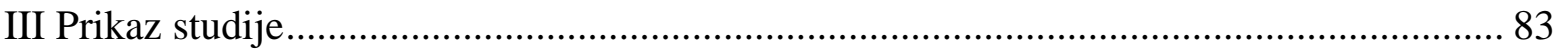

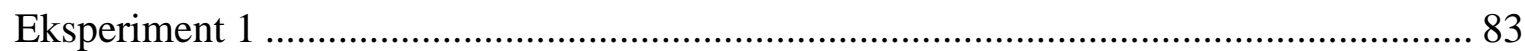

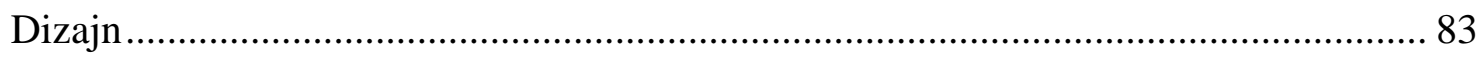

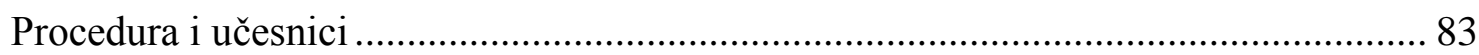

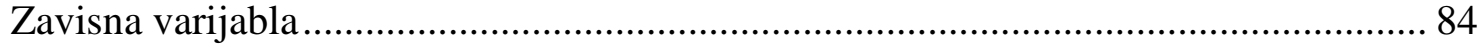

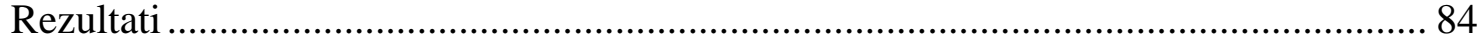

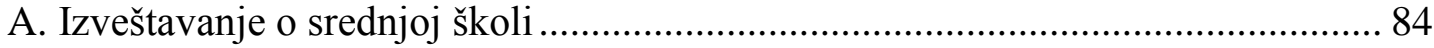

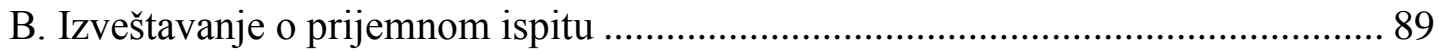

Povezanost sklonosti ka grešci preterivanja

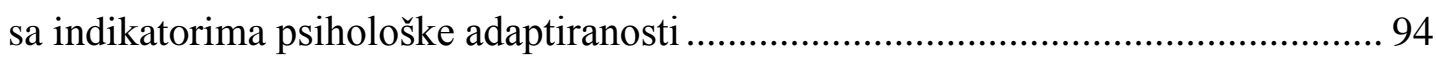

Predviđanje raspona greške preterivanja .......................................................... 95

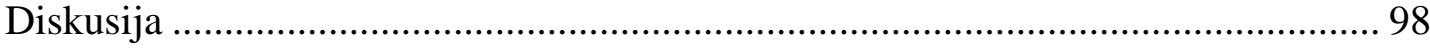

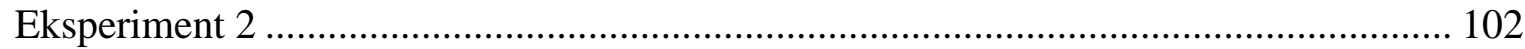

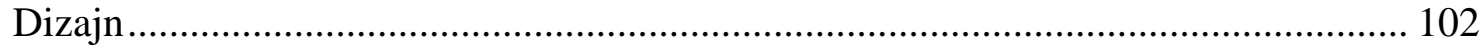

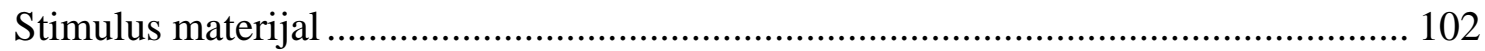

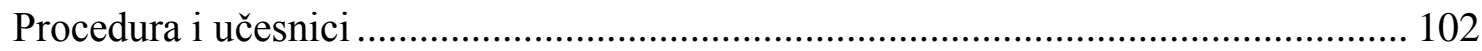

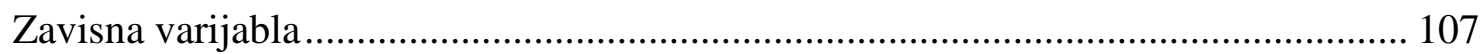

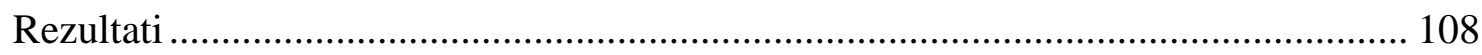

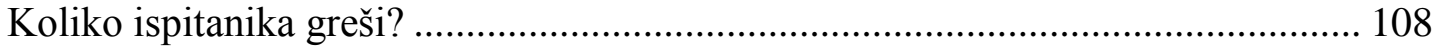

Koliko ispitanici greše? Intenzitet greške preterivanja .......................................... 110

Povezanost sklonosti ka grešci preterivanja

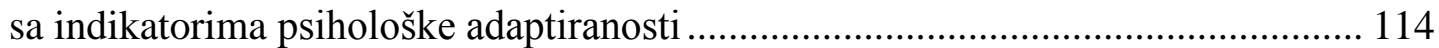

Predviđanje raspona greške preterivanja ........................................................ 115

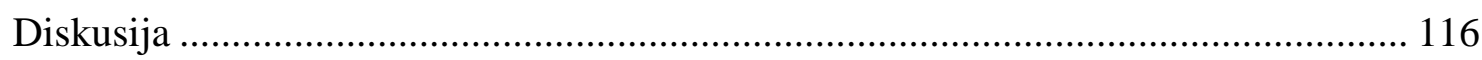

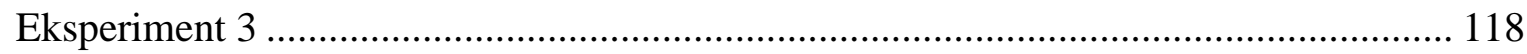

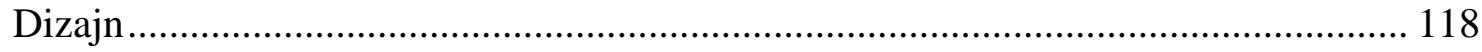

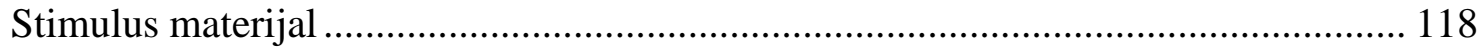

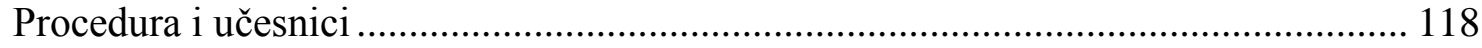

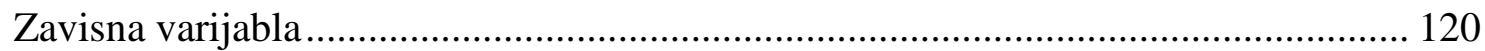

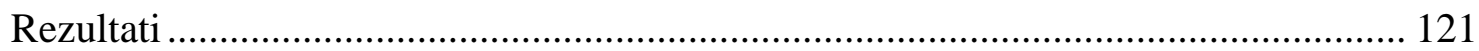

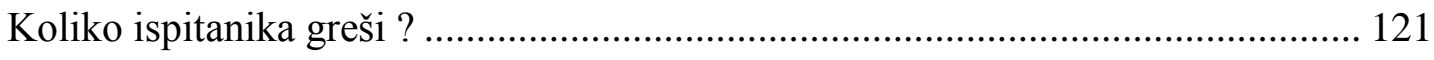

Koliko ispitanici greše? Intenzitet greške preterivanja ....................................... 123

Apsolutna greška u izveštavanju o postignuću na testovima................................. 126 
Povezanost sklonosti ka grešci preterivanja sa indikatorima psihološke adaptiranosti 127

Predviđanje raspona greške preterivanja ........................................................ 128

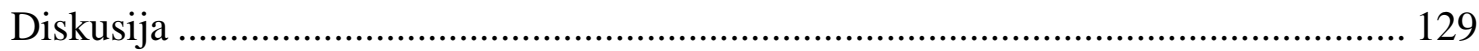

Eksperiment 4.1

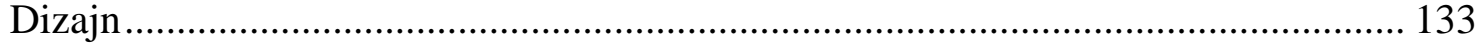

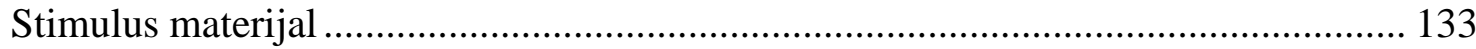

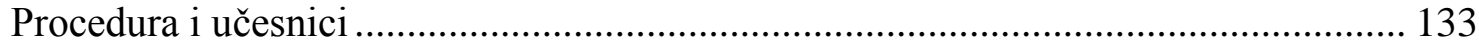

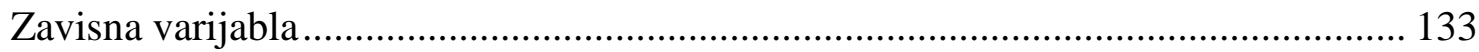

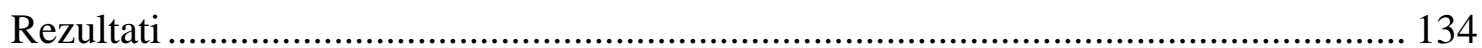

Intenzitet greške u proceni postignuća............................................................ 135

Apsolutna greška u proceni postignuća …......................................................... 137

Predviđanje raspona greške preterivanja (potcenjivanja) ....................................... 138

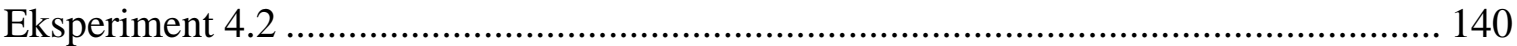

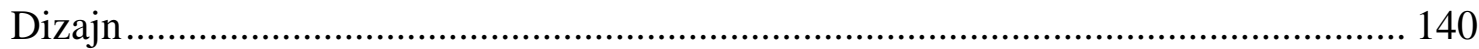

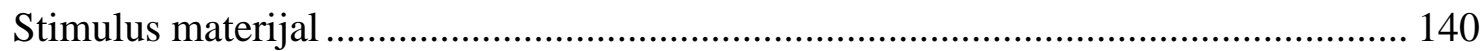

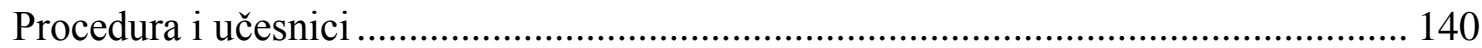

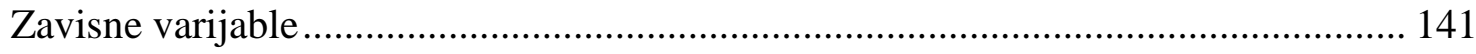

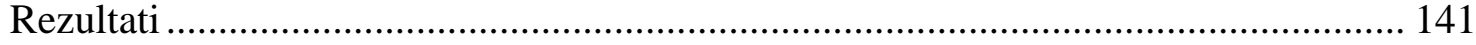

Predviđanje raspona greške preterivanja (potcenjivanja) ...................................... 144

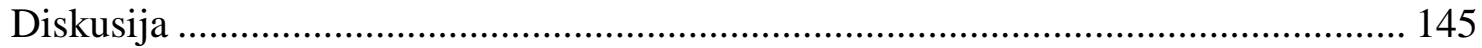

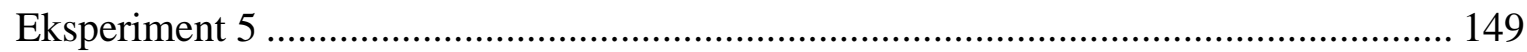

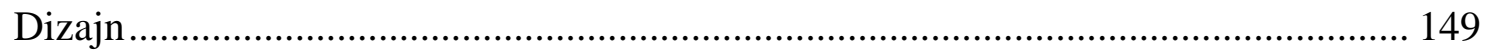

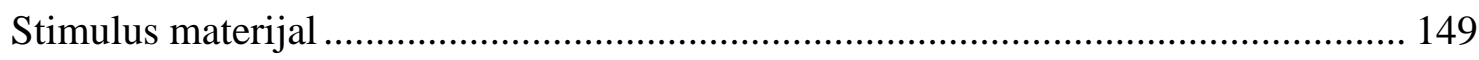

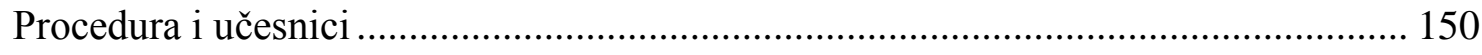

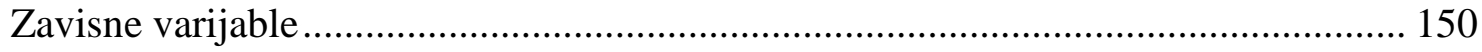

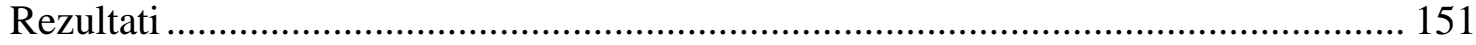

Greška preterivanja u spontanom navođenju atributa svoje i tuđe grupe ................ 151

Greška preterivanja u prisećanju postignuća svoje i tuđe grupe ............................. 152

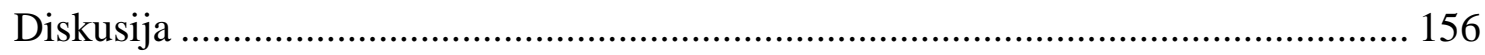

Povezanost greške preterivanja sa merama psihološke adaptiranosti na poduzorcima prema memorijskoj dostupnosti i javnosti situacije ............................. 158

Postoji li sklonost ka pozitivnoj samoevaluaciji? ......................................................... 164

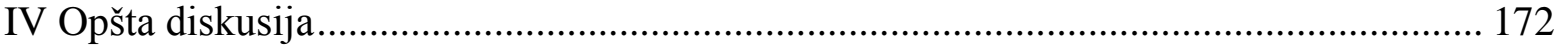


Praktične implikacije rezultata istraživanja ................................................................ 181

Ograničenja istraživanja i predlozi za buduća ............................................................ 183

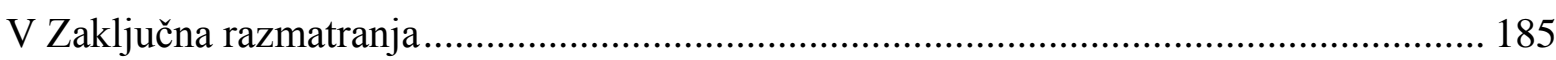

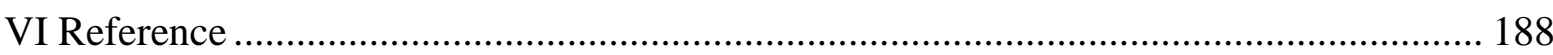

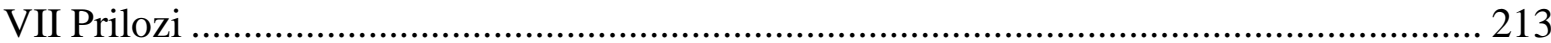


I Uvod

Naučnici i filozofi odavno su prepoznali da između sećanja i slike o sebi postoji bliska veza. Kada bismo bili lišeni mogućnosti učenja i pamćenja, bili bismo samo "prazan, osiromašen izraz sopstvene genetske konstitucije" (Le Doux, 2002, str.9). Iz druge perspektive, Grinvald je tvrdio da se prošlost pamti kao "drama u kojoj je onaj ko se priseća glavni glumac" (Greenwald, 1980, str. 604). Dakle, ne samo da je naša slika o sebi zasnovana na sećanjima na prošla iskustva, već je i prisećanje i rekonstrukcija prošlosti pod uticajem slike o sebi.

U ovom radu pokušaćemo da saznamo nešto o tome kako ljudi opažaju sebe i druge tako što ćemo ispitivati nesavršenosti u njihovom sećanju. Ako su slika o sebi i pamćenje u tako snažnoj interakciji, izučavanje načina na koji se pamćenje menja i motiva pod čijim uticajem se te izmene dešavaju, trebalo bi da doprinese i boljem razumevanju slike koje imaju o sebi i svetu koji ih okružuje.

U razmišljanju polazimo od dve osnovne pretpostavke: (a) ljudi su snažno motivisani da zadrže ili poboljšaju sliku koju imaju o sebi i (b) taj motiv posredno i neposredno utiče na saznajne procese, izazivajući različite vrste grešaka (pristrasnosti). 


\title{
Fenomen egotizma
}

\author{
"Čovek bira da veruje ono što želi da je istinito." \\ F. Bacon
}

\section{Koncept greške u socijalnoj kogniciji}

Pre nego što počnemo diskusiju, kratko ćemo se osvrnuti na naziv discipline iz čije perspektive ćemo interpretirati rezultate. Socijalna psihologija više od pola veka izučava procese kojima ljudi spoznaju druge ljude i sebe. Otprilike isto toliko vremena, socijalni psiholozi se spore oko naziva ove grane discipline. Počelo se, po analogiji sa procesima opažanja, sa terminom socijalna percepcija (Bruner \& Tagiuri, 1954), koji se i u našoj naučnoj sredini ocenjuje adekvatnim (Havelka, 2008), a i danas je u upotrebi (Spencer, Fein, Zanna \& Olson, 2003). Kritičari (Gilbert, 1998), međutim smatraju da je u ovom nazivu objekat neodređeno, a aktivnost netačno opisana: socijalno nam ne govori mnogo o aspektima koji se izučavaju (osobe, njihov temperament, aktivnosti, bračni status?), a percepcija je u ovom slučaju veoma udaljena od percepcije per se - ovde se pod opažanjem podrazumevaju mišljenja, sudovi i uverenja koje ljudi stiču o drugima i sebi. Uvideviši da je kognicija adekvatniji termin za ovu vrstu procesa, naziv ove oblasti izučavanja prekraja se u socijalna kognicija, što je danas institucionalno prihvaćeno, ako je suditi po naslovima vodećih udžbenika (Fiske \& Taylor, 2008; Moskowitz, 2005; Kunda, 1999).

Dotaćićemo se ukratko velikih tema kojima se bavila socijalna kognicija, i to hronološkim redom, da bismo objasnili kako se, od proučavanja "tačnosti" došlo do proučavanja "grešaka" u saznavanju o drugima i sebi. Početne ideje istraživača procesa socijalne kognicije delovale su razumno i jednostavno: trebalo je samo izmeriti objekat (drugo ljudsko biće, u ovom slučaju) u pogledu određene dimenzije, izmeriti opažanje objekta u pogledu te dimenzije, i oduzeti jedno od drugog. Tako se dobijao indeks tačnosti saznavanja osoba, za koji se pretpostavljalo da može varirati u zavisnosti od situacije i ličnih karakteristika opažača. Ovakav, objektivistički pristup, međutim, imao je očiglednih mana. Pre svega, prikupljeni rezultati bili su nedosledni - nisu ukazivali da postoji sposobnost koju bismo nazvali socijalnom senzitivnošću, i koja bi garantovala tačnije saznavanje socijalnog sveta. Zatim, "izmeriti objekat" možda je zvučalo jednostavno, ali psiholozi još uvek nisu raspolagali (i ne raspolažu) dovoljno preciznim instrumentima kojima bi se to učinilo, tim pre što su objekti u 
ovom slučaju veoma složeni, a uz to i skloni promeni. Drugim rečima, "teškoće u razvoju kriterijumske mere pokazale su se najvećom preprekom izučavanja tačnosti socijalne kognicije" (Kenny, 1994, str.136 ). Pored toga, metodolozi (Cronbach, 1955) su ukazivali na neodrživost jednostavnog oduzimanja kao načina izračunavanja indeksa tačnosti.

Vreme je bilo da se pomeri akcenat sa pitanja koliko tačno na pitanje kako, da se pomeri akcenat sa efekata procesa na sam proces. Važno je naglasiti da pritom nije nestao interes za merenje uspešnosti ovakvog procesa. Promenio se način na koji se definiše uspeh i pogreška, i u tom smislu se odustalo od objektivističkog pristupa. Novi talas istraživanja na elegantan način zaobišao je problem merenja objekta: novi istraživači (Aš, Hajder) varirali su informacije dostupne opažaču i pratili promene u opažanju osobe $u$ zavisnosti od tih varijacija. Na primer, ako osobu opisuje niz atributa, hoće li redosled pristizanja tih atributa uticati na utisak koji imamo o njoj? Po logici, utisak o osobi trebalo bi da bude isti ako je u pitanju isti skup atributa. Ogledi su pokazali da se jednostavnim promenom redosleda postiže se velika razlika u ukupnom utisku - starije informacije "boje" nove informacije. Tačnost više nije bila definisana kao razlika između naučno izmerene i naivnim okom opažene osobine - tačnost je definisana preko razlike između načina na koji opažač tretira informacije koje su mu dostupne i logičkog pravila koje nalaže da se informacije tretiraju na određen način. Logički pristup rezultirao je ogromnim brojem istraživanja koja su registrovala raznorodne pristrasnosti ${ }^{1} \mathrm{i}$ odstupanja od logičkih pravila. Osamdesetih godina, akumulirani empirijski nalazi o ovim pristrasnostima dobijaju i svoju teorijsku osnovu, pre svega u radovima Kanemana i Tverskog (Kahneman \& Tversky, 1979; 1984, Tversky \& Kahneman, 1981), a istraživači se još spremnije posvećuju izučavanju grešaka. U osnovi grešaka, tvrdi se, leže četiri bazična fenomena koje možemo nazvati: idealizam (ljudi opažaju stvari onakvima kakve očekuju da budu), egotizam ${ }^{2}$ (ljudi opažaju stvari onakvima kakve bi želeli da budu), realizam (ljudi misle da opažaju stvari onakvima kakve jesu), i cirkumstancijalizam (ljudi razmišljaju samo o stvarima koje opažaju). Ako pođemo od ovakve klasifikacije, prostim prebrojavanjem utvrdićemo da je naučnike najviše okupirala kategorija grešaka koju zovemo egotizam (Gilovich, Griffin \& Kahneman, 2002). Razlog za

\footnotetext{
${ }^{1}$ U tekstu će termini "pristrasnost" i "greška" biti alternativno korišćeni, mada je u anglosaksonskoj literaturi usvojen termin "bias", a termin "error" se ređe sreće (bias se može prevesti i kao iskrivljenje, ali nam se ovaj termin ne čini dovoljno jednoznačnim). U principu, moguće je da pristrasnost ne dovodi do greške u saznavanju socijalnog sveta, ukoliko se ona definiše na klasičan način. Ako, međutim, pod greškom podrazumevamo odstupanje od logičkog pravila, onda ima osnova za ovo terminološko izjednačavanje.

${ }^{2}$ Egotizam ne treba mešati sa egoizmom: prvi pojam se odnosi na grupu kognitivnih pristrasnosti koje pojedincu omogućavaju da se vidi u pozitivnom svetlu, a drugi na na motiv da se maksimalizuje lična dobrobit; egoizam se često posmatra kao suprotnost altruizmu, koji se definiše kao briga o drugim ljudima i njihovoj dobrobiti, mada ih neki autori vide kao nezavisne motive (Krebs, 1991).
} 
to možda leži u zdravorazumskim očekivanjima - ako već u nekim situacijama dolazi do iskrivljavanja onoga što opažamo, verovatno je da će te promene biti u korist opažača. Skloni smo da usvojimo uverenja o sebi koja osnažuju ego i uverenja o svetu koja nam deluju utešno. Možda je u pitanju nastavak tradicije - iste su pretpostavke o odnosu želja i rasuđivanja veoma davno iznosili i rodonačelnici psihološke nauke- Vilijem Džejms i Sigmund Frojd (prema Sedikides \& Gregg, 2008). Pored toga, izučavanje ove vrste grešaka otvara vrlo inspirativnu debatu o odnosu motivacije i kognicije koja može dati važne odgovore o načinu na koji ovi fundamentalni procesi utiču jedan na drugi. Na kraju, još jedan razlog može biti primenljivost šire klase adaptivnih objašnjenja na fenomen egotizma. Pre nego što damo konkretne primere egotizma, pokušaćemo da objasnimo zašto je ova vrsta grešaka idealan primer uticaja motiva na saznajne procese. 


\section{Pitanje odnosa motivacije i kognicije}

"Razum je, i treba da bude, rob strasti."

D. Hume

Tokom pedesetih godina prošlog veka, u psihologiji percepcije javljaju se neke nove ideje, gotovo jeretičke za to doba i tu oblast psihologije. Najkontroverznija tvrdnja ove nove struje (nazvana je "Novi pogled") bila je da opažanje može biti pod uticajem takozvanih "toplih" (motivacionih) konstrukata - vrednosti, potreba i želja (Gilbert, 1998). Oni nisu tvrdili samo da motivi određuju da li ćemo prihvatiti ili odbaciti ono što opažamo, već da motivi određuju šta ćemo i kako opaziti (na primer, fenomen perceptivne akcentacije ili odbrane). U socijalnoj psihologiji ovakve novine nisu izazvale toliko burnu reakciju kao u psihologiji percepcije, kako zbog toga što su motivi kao takvi oduvek primarni predmet proučavanja socijalnih psihologa, tako i zbog toga što se socijalna psihologija ne bavi bazičnim (vizuelna ili auditivna percepcija), već višim procesima poput odlučivanja i vrednovanja u kojima je uticaj motiva teško izgubiti iz vida. Upravo to se, međutim, desilo osamdesetih godina prošlog veka kada se činilo da su motivaciona objašnjenja kognitivnih grešaka stvar prošlosti. Kako su to kognitivna objašnjenja postala jedina prihvatljiva objašnjenja?

Zamislite da je grupi studenata dat test inteligencije. Polovina je dobila lažan rezultat prema kome su briljirali, a druga polovina rezultat prema kome su značajno podbacili. Prva grupa ocenjuje test kao visoko pouzdan, dok ga druga odbacuje kao amaterski. Motivaciono objašnjenje rezultata se samo nameće - prvoj grupi prija ono što je čula, a drugoj grupi ne prija, naprotiv, ugrožava njihovu sliku o sebi. Druga grupa ima potrebu da devalvira vrednost testa. Koliko god delovalo logično, ovo nije i jedino objašnjenje rezultata. Studenti prestižnih univeziteta obično imaju ličnu istoriju akademskih uspeha, pa u skladu s tim i razumno očekivanje da će se takvi uspesi nastaviti. Čak i posmatrači sa strane imali bi isto očekivanje - a oni nemaju nikakav prikriveni interes u ovoj stvari. Isti nalazi, dakle, mogu biti objašnjeni pozivanjem na motivacione, ali i na kognitivne mehanizme (npr. očekivanja ili znanje o tome da je neko uložio napor u izvršavanje zadatka). Neki teoretičari (Tetlock \& Levi, 1982), analizirajući veliki broj studija u kojima se javio ovaj problem (nekada se problem interpretacije javio naknadno, pošto je autor zauzeo jedno, obično motivaciono gledište) čak su tvrdili da nikada neće biti moguće dobiti jednoznačne dokaze o uticaju motivacije na suđenje pošto će uvek biti moguće ponuditi i alternativnu, kognitivnu interpretaciju nalaza. 
U trci ova dva tipa objašnjenja, kognitivistička su, tvrdilo se (Miller \& M. Ross, 1975; Nisbett \& L. Ross, 1980) parsimonična - elegantnije interpretiraju rezultate pozivajući se na manji broj konstrukata.

Ovi argumenti delovali su snažno i ubedljivo tokom čitave dve dekade. Tome je doprinelo i cvetanje eksperimentacije u domenu kognitivne psihologije, koju su onda druge discipline (u mnogome i socijalna psihologija) rado pozajmljivale.

Do početka devedesetih, međutim, nagomilali su se dokazi koje nije tako lako bilo alternativno (nemotivaciono) objasniti. Neki socijalni psiholozi (Kunda, 1990,1999; Kunda \& Sanitioso, 1991) smatrali su da oni nedvosmisleno ukazuju na uticaj motivacije na kogniciju i ne dozvoljavaju mogućnost rezervnog tumačenja.

a. Ogledi koji se ne tiču samoprocene. Ako se ljudima, na primer, daju ste informacije o nekoj nepoznatoj osobi, oceniće je pozitivije ukoliko očekuju da će im to biti partner u u diskusiji ili na sastanku "na slepo" (Berscheid, Graziano, Monson \& Dermer, 1976). Eliminišući self kao objekat procene, eliminiše se i eventualno prethodno o njemu (očekivanja i verovanja).

b. Ogledi koji mere fiziološke parametre tokom kognitivnih aktivnosti za koje se pretpostavlja da su obojene afektom (npr. u situaciji disonance). Motivaciona objašnjenja predvidela bi dodatnu telesnu pobuđenost, a kognitivistička ne. Fiziološke mere su u većini slučajeva govorile o pobuđenosti (pregled ovih nalaza u Pyszczynski \& Greenberg, 1987).

c. Ogledi u kojima se potkrepljuje (insentiv je često novac) brzo donošenje odluka (npr. Buehler, Griffin \& Mac Donald, 1997) dolaze do zaključka da nagrada doprinosi nekim temporalnim pristrasnostima, i to delujući na kognitivne mehanizme: optimističku procenu potrebnog vremena za završetak zadatka, povećanu pažnju za buduće i ignorisanje prošlih događaja.

d. Ogledi u kojima se pruži alternativni način zadovoljenja određenog motiva (npr. Gramzow \& Willard, 2006): ispitanici kojima je data prilika za samoafirmaciju na drugom polju u manjoj meri će pokazivati tendenciju ka grešci preterivanja $u$ poređenju sa grupom kojoj motiv za samoafirmacijom nije zadovoljen (prva grupa izveštavaće realnije o svojim rezultatima na testu sposobnosti od druge).

e. Ogledi u kojima se manipuliše ego-involviranošću, odnosno preferencijom ka donošenju određenih zaključaka, pamćenju određenih prošlih ili predviđanju određenih budućih dešavanja. Uzmimo za primer poznati Vejsonov zadatak u kojem ispitanici treba da okrenu minimalni broj karata da bi proverili izvesno pravilo koje se 
odnosi na pisani sadržaj prikazan na tim kartama (Wason, 1966). Optimalna strategija za rešavanje ovog zadatka je opovrgavanje ${ }^{3}$. Ukoliko su ispitanici motivisani da opovrgnu pravilo (ono na primer glasi "Emotivno nestabilni ljudi kraće žive", a ispitanik je klasifikovan kao emotivno nestabilan; ili "Irci su alkoholičari", a ispitanik je Irac), oni prave značajno manje grešaka nego nemotivisani ispitanici (procenat uspešnosti kod prvih je 40\%, a kod drugih 20\%) (Dawson, Gilovich \& Regan, 2002; Jovanović \& Žeželj, in press).

Akumulacija ovakvih dokaza navela je neke naučnike da zaključe da argument o parsimoničnosti ne ide više u prilog kognitivističkim objašnjenjima. "Naprotiv, sada se čini da jedan konstrukt, motivacija, može da objasni niz različitih fenomena, od ego-zaštićujućih atribucija, iskrivljenih uverenja o drugima do pristrasne interpretacije naučnih dokaza. Mnogi od ovih fenomena ne mogu se objasniti isključivo kognitivnim konceptima... Na kraju, međutim, treba istaći da sa novim uvidima u mehanizme motivisanog rezonovanja, razlika između motivacionih i kognitivnih koncepata postaje sve tanja" (Kunda, 1999, str. 232). Slično rezonuje i Gilovič, koji ukazuje na to da je dilema motivaciono-kognitivno umnogome lažna dilema (Gilovich, 1991). Naša želja da svet i sebe vidimo na određen način može iskriviti viđenje sebe i sveta samo do određenog stepena. Motivacija najčešće deluje posredno, preko načina na koji obrađujemo relevantne informacije: koje ćemo informacije uzeti u obzir, koju težinu ćemo im dati, kako ćemo ih integrisati u celinu.

Na kraju, "topla" kognicija (egotizam) i "hladna" kognicija (idealizam), odnosno želje i očekivanja imaju zajedničke efekte na kognitivne ishode i teško ih je, a nekada i nepotrebno, razlučiti (Kruglanski, 1996).

\footnotetext{
${ }^{3}$ Standardna verzija Vejsonovog zadatka podrazumeva prikazivanje lica četiri karte sa simbolima A, B, 4 i 7, pri čemu je zadatak ispitanika da okretanjem karata, na osnovu sadržaja na naličju, proveri pravilo koje glasi: "Ako je na licu karte ispisan samoglasnik, na njenom naličju piše paran broj". Logički ispravna strategija sastoji se u izboru karata sa slovom A i brojem 7 na licu.
} 


\section{Definisanje i primeri egotizma}

Naziv ove klase kognitivnih pristrasnosti, egotizam, sugeriše da se greške odnose na uverenja o sebi. Iako nije nužno da budemo na ovaj način blagonakloni isključivo prema $\mathrm{sebi}^{4}$, istraživanja pokazuju da je to ipak najčešći slučaj. Veliki broj dokaza ukazuje na to da smo skloni da precenjujemo sopstvene sposobnosti, doprinos u aktivnostima, kao i verovatnoću da će nam se desiti pozitivni događaji. Ljudi, na primer, smatraju da su pametniji, veštiji i pravedniiji od prosečnog predstavnika svoje grupe. Ovaj fenomen je sistematski istraživan i pokazao se veoma robustnim (naziva se "fenomen nadprosečnosti" ili "efekat jezera Vobegon", po priči u kojoj su "muškarci sa jezera Vobegon lepi, žene snažne a deca iznad proseka"): u jednoj studiji na preko milion američkih srednjoškolaca (sproveo univerzitet Prinston 1976, prema Gilovich 1991), 70\% je procenilo da je iznad proseka po pitanju liderskih sposobnosti (samo $2 \%$ sebe je svrstalo ispod proseka), a svih $100 \%$ (!) sebe je svrstalo u nadprosečne po sposobnosti da se prilagode drugim ljudima.

Ljudi takođe aktivno konsturišu teorije po kojima se verovatnijim čini da će im se lepe stvari dogoditi u budućnosti, a da će ih negativne zaobići (takozvani nerealistični optimizam): kada im se saopšti, na primer, prosečan procenat razvedenih brakova, oni očekuju da njihov neće biti u toj kategoriji; kada im se saopšti prosečan broj obolelih od izvesnih ozbiljnih bolesti, oni ne svrstavaju sebe u rizičnu grupu; kada im se, međutim, prezentuje procenat oženjenih ili zaposlenih ljudi, ljudi će očekivati da budu među njima (Kunda, 1999; Sanna \& Chang, 2006). Stepen kontrole nad životnim događajima takođe se sistematski precenjuje (iluzija kontrolabilnosti), kao i stepen kontrole nad događajima koji su određeni slučajem (na primer, kockanje) (Langer, 1975; Gilovich, 1983).

Koriste se i suptilnije strategije koje nam omogućavaju da održimo povoljnu sliku o sebi: ljudi procenjuju, na primer, da su njihove pozitivne osobine centralne, a negativne periferne za ocenu sebe i drugih (Sedikides, 1993), razvijaju teorije po kojima osobe koje imaju njima slične karakteristike imaju više šanse za uspeh (Kunda, 1987), idiosinkratično definišu osobine ličnosti: ukoliko, na primer, sebe smatraju dominantnim, opisivaće ponašanja koja karakterišu ovakve ljude kao većinom pozitivna; ukoliko za sebe smatraju da nisu

\footnotetext{
${ }^{4}$ Može se, na primer, precenjivati i podrška koju stavovi koje lično zastupamo imaju u populaciji ili snaga argumenata koji potkrepljuju naše naspram suprotnih stavova (Lord, Ross \& Lepper, 1979). Precenjuju se, takođe, pozitivne osobine prijatelja ili bliskih rođaka (Moskowitz, 2005). Postoji opravdanje da se i ovakva iskrivljenja svrstaju u egotizam, ako sopstvene stavove i preferencije, kao i ljude koji su nam bliski, posmatramo kao "ego markirane" (lične), naspram onih koji to nisu.
} 
dominantni, navodiće uglavnom negativna ponašanja; ako ih, međutim, eksperimentalna manipulacija navede da za sebe misle da spadaju u drugu grupu (dominantnima kažemo da to nisu i obrnuto), najčešće menjaju sadržaj opisa ponašanja, dodajući ponašanja pozitivne odnosno negativne valence (Dunning \& Mc Elwee, 1995).

Nešto manje suptilno, ali u istu svrhu, ljudi su skloni da precenjuju svoje sposobnosti i postignuća. Tako između 50\% i 60\% ljudi daje pozitivno pristrasne izveštaje o fizičkim karakteristikama, kao što su visina i težina (Hancock, Toma \& Ellison, 2007); većina ispitanika takođe je sklona da precenjuje svoj učinak na testovima inteligencije, atletskih sposobnosti i vožnje (Groeger \& Grande, 1996; Hansford \& Hattie, 1982; Van Yperen, 1992), kao i na testovima ličnosti (Crary, 1966).

Kako je naše autobiografsko sećanje ključan izvor informacija koje imamo o sebi, a proces pamćenja nije puko registrovanje i beleženje događaja, već je podložan različitim greškama, iluzijama, i distorzijama (Schachter, 1999; Schacter et al., 2003), u našem radu bavićemo se upravo egotizmom pamćenja, odnosno uticajem motiva za očuvanjem pozitivne slike o sebi na proces pamćenja informacija o sebi. Na početku ćemo dati kratak pregled istraživanja autobiografskog pamćenja, tačnosti upamćenih sadržaja a onda se detaljnije baviti sistematskim distorzijama u autobiografskom pamćenju koje se mogu svesti pod fenomen egotizma.

Preko 2000 objavljenih studija (prema Pezzo, 2003) bavi se upravo sistemskim greškama u pamćenju, precizirajući uslove u kojima se javljaju odnosno ne javljaju. Greške u pamćenju nazivaju se sistemskim (Sanitioso, Kunda \& Fong, 1990), zato što njihov efekat nije slučajan i nepredvidljiv- naprotiv, efekat ovih grešaka dosledno doprinosi pozitivnijem vidjenju sebe, drugih, i sebe u interakciji sa drugima. 


\section{Pamćenje kao kognitivni proces}

"Bog nam je dao pamćenje da bismo imali ruže u decembru."

J.M. Barrie

Psiholozi obično definišu memoriju kao sistem uskladištenih znanja pojedinca, koji čini kognitivnu bazu učenja. Pamćenje je složen proces koji se odvija u tri faze: kodiranje informacija, skladištenje informacija i pronalaženje informacija u memoriji (Okvir 1). U ovom radu držaćemo se tih terminoloških razgraničenja, pa ćemo proces skladištenja zvati upamćivanjem, a proces pronalaženja sećanjem, dok ćemo pamćenjem zvati nadređen koncept koji obuhvata sva tri procesa.. ${ }^{5}$

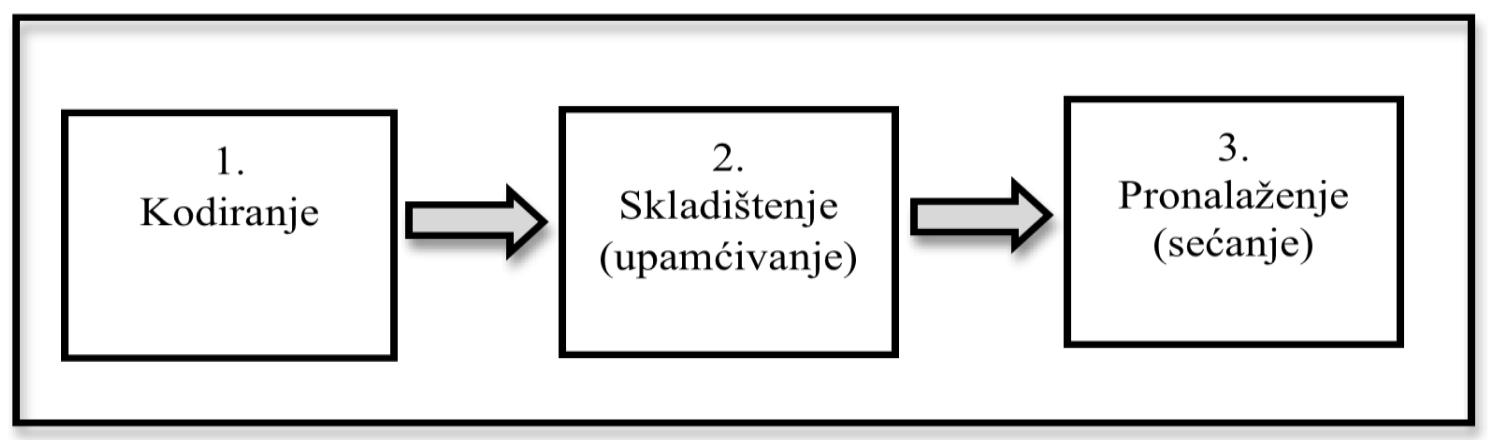

Okvir 1. Faze u procesu pamćenja

Ukoliko ne bismo imali mogućnost da sačuvamo mentalne reprezentacije prošlih događaja, ne bismo ni na koji način profitirali iz iskustva. Pamćenje takođe oslobađa mišljenje i ponašanje diktata trenutnih okolnosti i situacije u kojoj se nalazimo, i dozvoljava i nam da opažamo, razmišljamo i reagujemo na prošle događaje (Kihlstrom, 2002).

Uskladišteno znanje može imati dve osnovne forme: proceduralno znanje podrazumeva apstrahovana pravila koja usmeravaju aktivnosti, a deklarativno znanje je zapravo činjenično znanje o svetu koji nas okružuje (Shachter \& Tulving, 1994). Proceduralno znanje može podrazumevati motoričke i kognitivne veštine, a deklarativno epizodičko i semantičko pamćenje. Epizodičko pamćenje je pamćenje sopstvenih aktivnosti i iskustava, a semantička generičko, apstraktno znanje koje nije vezano za konkretan događaj. Iako su i proceduralno i semantičko pamćenje lišeni konkretnih sadržaja, odnosno nisu vezani za određen događaj, najjednostavnije je razlikovati ih po tome da li skladište pravila o tome Kako nešto raditi (proceduralno) ili Šta predstavlja određen koncept (semantičko).

\footnotetext{
${ }^{5}$ U literaturi na engleskom jeziku, izraz memory koristi se da označi uskladišteno znanje, ali i kao nadređen pojam, koji obuhvata i upamćivanje (eng. memorizing; encoding) i prisećanje (eng. retrieval).
} 
Primer koji sledi je pojednostavljena ilustracija različitih načina skladištenja znanja koja nazivamo razliičitim tipovima memorije:

Epizodičko pamćenje: Prošlog utorka jela sam piletinu sa karijem.

Semantičko pamćenje: Kari je ljuti začin.

Proceduralno pamćenje: Set pravila o rukovanju nožem i viljuškom.

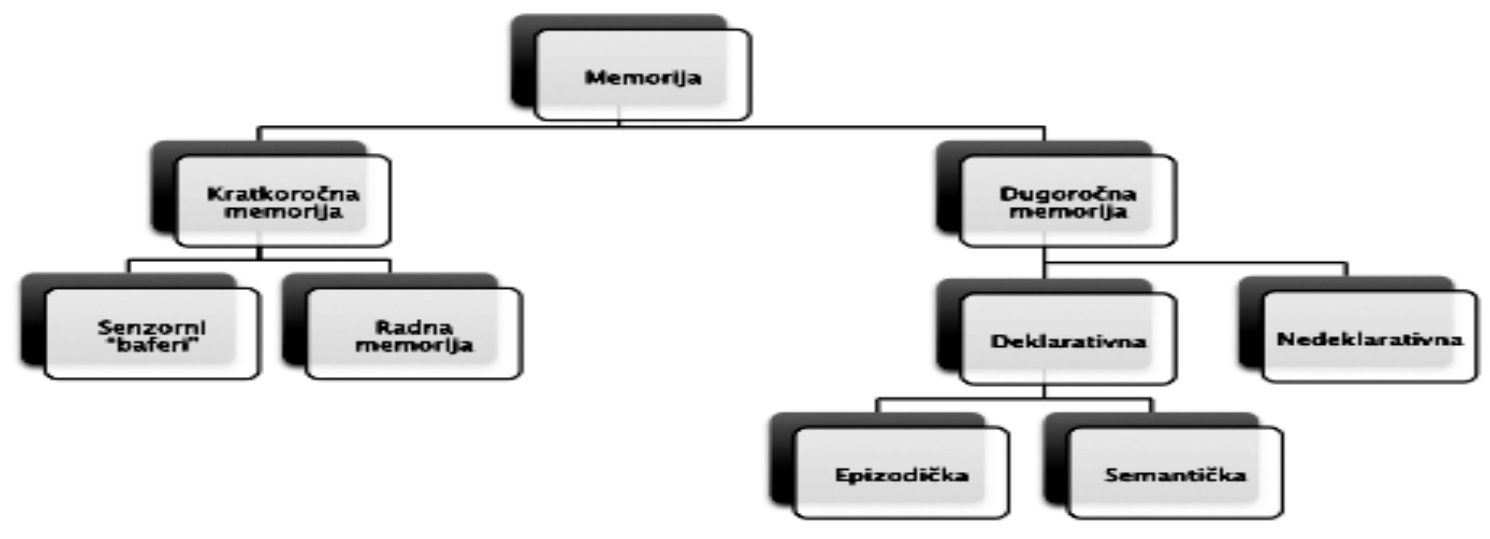

Slika 1 Jednostavna taksonomija memorijskih sistema (Shachter \& Tulving, 1994, str. 8).

S druge strane, laički koncept memorije najčešće ne uključuje ovu vrstu znanja, već podrazumeva isključivo epizodičku memoriju.

\section{Autobiografsko pamćenje}

Pošto ćemo se dalje u radu baviti pristrasnim pamćenjem ličnih iskustava, detaljnije ćemo pokušati da definišemo koncept autobiografskog pamćenja i razgraničimo ga od ostalih tipova pamćenja.

Ukoliko se autobiografsko pamćenje odnosi na sećanja na događaje koje smo lično iskusili, u koje kategorije u navedenoj podeli spada?

Bedli (Baddeley, 1988) odredio je autobiografsko pamćenje kao epizodičko (nasuprot semantičkom- Tulving, 1972, 1983) i kao skladište deklarativnog znanja (nasuprot 
proceduralnom- Anderson, 1976). Autobiografsko pamćenje je po prirodi epizodičko zato što kodira događaje koji imaju jedinstveno mesto u prostoru i vremenu, i deklarativno zato što se odnosi na činjenično znanje, znanje koje se može predstaviti rečeničnim, propozicionim reprezentacijama. Differentia specifica autobiografskog pamćenja je uključenost selfa (Baddeley, 2009).

Primer koji sledi ilustrovaće šta zapravo psiholozi podrazumevaju pod autobiografskim pamćenjem (primer je preuzet iz Kihlstrom, 2002 i prilagođen):

Pođimo od sledećeg događaja:

Mađioničar je vešto dobacio štap pomoćniku

Svaki element ove tvrdnje vezan je za uskladišteno znanje, u ovom slučaju o tome kako izgledaju mađioničari i mađioničarski pomoćnici. Iako opisuje specifičan događaj, ovo još uvek nije epizodičko sećanje: u pitanju je samo zabeležena činjenica. Da bi postao epizodičko sećanje, mora se "ukotviti" u prostorni i vremenski kontekst. Na primer:

Mađioničar je vešto dobacio štap pomoćniku na Marijinom rođendanu u četvrtak.

To je, međutim, sada samo istorijska činjenica. Zapis u autobiografskoj memoriji mora da uključuje mentalnu reprezentaciju sebe kao agensa ili svedoka radnje. Na primer:

Videla sam mađioničara kada je dobacio...

ili

Bila sam impresionirana kada je mađioničar dobacio...

ili čak

Pomagala sam mađioničaru i on mi je dobacio...

Postoje i autori (Nelson, 1993; Nelson \& Fivush, 2004) koji insistiraju na tome da nisu sva epizodička sećanja autobiografska, već su to isključivo ona koja su dugotrajna i uključuju centralne aspekte slike o sebi. Razliku između ovako definisanih "običnih" epizodičkih i autobiografskih sećanja, međutim, nije lako napraviti: ostaje pitanje da li je svako autobiografsko sećanje nužno dugotrajno i da li sećanja na događaje u kojima smo učestvovali, a ne uključuju centralni aspekt slike o sebi po prirodi ne mogu biti dugotrajna. Pored toga, istraživanja ukazuju na to da se obe vrste sećanja oslanjaju na iste neurološke sisteme (Nelson \& Fivush, 2004). Stoga se čini opravdanijim tretirati sve događaje u kojima smo učestvovali kao akteri kao autobiografske, a eventualno praviti razliku između formativnih i onih koji to nisu, pri čemu se razlika može zasnivati na proceni uticaja tog događaja na sliku o sebi (London \& Kulkofsky, 2010).

Može se, međutim, razmišljati i u suprotnom smeru: da li je nužno da autobiografsko pamćenje bude isključivo epizodičko? Ukoliko pod autobiografskom memorijom 
podrazumevamo skladište informacija koje se odnose na život konkretne osobe, onda se tu mogu naći i znanja koja bi pre bila semantička (ne vezuju se za konkretan događaj, nisu ukotvljena u jednoj prostorno-vremenskoj tačci): na primer, Bio sam nemoguć trogodišnjak; Bila sam stidljiva u pubertetu i slično. Ovo posebno napominjemo zbog toga što se i jedna i druga vrsta sećanja ravnopravno tretiraju kao autobiografska, a zapravo među njima postoji razlika $u$ nivou opštosti koju treba imati $u$ vidu prilikom tumačenja istraživanja autobiografskog pamćenja, uključujući i naše istraživanje o kome će kasnije biti reči. 


\section{Istorijski pregled istraživanja autobiografskog pamćenja}

U pregledu literature u vezi sa pamćenjem, Konvej primećuje da je inicijalni interes za autobiografsko pamćenje i pitanje tačnosti upamćenih autobiografskih događaja koji je postojao krajem 19. i početkom 20. veka nekako zamro, i da je usledio jaz u istraživanjima sve do 1970ih godina. Ovakav neobičan prekid u istraživačkim aktivnostima on zove "stotinu godina ćutanja" (za detaljan pregled razvoja oblasti autobiografskog pamćenja vidi Conway, 1990; Conway \& Pleydell-Pearce, 2000). Većina istraživača sklona je da ovu pauzu interpretira kao posledicu dominacije kvantitativne orijentacije $u$ istraživanju procesa pamćenja.

Kako je pamćenje slojevit i veoma složen fenomen, istražuje se u okviru niza psiholoških disciplina (kognitivna psihologija, psihologija ličnosti, socijalna psihologija, klinička psihologija, neuropsihologija). Stoga se čini da je prirodno da postoji pluralizam u teorijskim i empirijskim pristupima. Postoje autori (Koriat, Goldsmith \& Pansky, 2000) koji smatraju da zapravo postoje dve glavne struje u istraživanjima pamćenja.

Kvantitativna struja, koja je dominirala eksperimentalnim istraživanjima procesa pamćenja tokom gotovo sto godina, potiče od Ebinghausovih eksperimenata (Ebbinghaus, 1895) u kojima se bavio uspešnoću u zadacima upamćivanja, za željom da popravi efikasnost u učenju. Memorija se u okviru ove struje posmatra kao skladište diskretnih informacija koje se kasnije mogu preuzeti (Roediger, 1980), a efikasnost upamćivanja evaluira se preko broja ajtema koji su dostupni nakon određenog vremenskog perioda. Standardna tehnika kojom se istraživači služe je tehnika memorisanja lista reči- ovo je i dalje najzastupljeniji način izučavanja pamćenja u većini objavljenih naučnih studija.

Tokom devedesetih godina, međutim, na snazi dobija i drugačiji istraživački pristup pamćenju, inspirisan svedočanstvima iz stvarnog života, najčešće iz psihoterapije i sudske prakse (Loftus, 1997a, 2004). Ovaj pristup orijentisan je na tačnost, a ne na kvantitet upamćenog, a istorijski koreni mogu se pronaći u Bartletovim radovima i njegovom shvatanju sećanja kao rekonstruktivnog a ne reproduktivnog procesa (Bartlett, 1932). Ovde se sećanje evaluira preko korespodencije između izveštaja i stvarnog događaja, sa akcentom na vrsti promena koje se dešavaju, procesom izmene i motivima za takvu promenu.

Zašto je autobiografsko pamćenje bilo zapostavljeno u godinama dominacije kvantitativne paradigme? Za to postoji nekoliko očiglednih razloga. Pre svega, u kvantitativnim istraživanjima najčešće se koristi tehnika memorisanja liste reči, čiji nepovezani stimulusi 
nemaju poseban značaj za subjekta. Nasuprot tome, sadržaj autobiografske memorije je "specifičan, ličan, dugotrajan i obično značajan za self-sistem. Fenomenološki, sadržaj autobiografske memorije je lična istorija pojedinca" (Nelson, 1993, str. 8). Stoga su suštinska pitanja kojima se bave istraživači autobiografskog pamćenja upravo značenje koje pojedinac učitava događajima, distorzije koje pravi pod uticajem različitih motiva i vremenskoprostorni kontekst događaja- sasvim različita pitanja od onih na koje pokušavaju da odgovore istraživači u okviru kvantitativne paradigme, koji se bave efikasnošću pamćenja i mogućnostima poboljšanja efikasnosti, a u svojim ogledima upravo teže da se oslobode lične uključenosti i konteksta kao konfundirajućih varijabli.

\section{Tačnost i greške u autobiografskom pamćenju}

Iako će veći deo teksta koji sledi biti posvećen upravo netačnostima u autobiografskom pamćenju, važno je da to ne proizvede utisak da je ljudsko pamćenje veoma varljivo i u potpunosti nepouzdano. Memorija nipošto nije sasvim proizvoljna rekonstrukcija prošlosti, već njen uglavnom veran zapis. Centriranost psihologa na greške potiče uglavnom iz potrebe da se proučava uticaj motiva na proces pamćenja.

S druge strane, u autobiografskoj memoriji događaji nisu pohranjeni upravo onako kako su se odigrali. To dakle nije snimak našeg života, koji nam stoji na raspolaganju kada želimo da evociramo prošla dešavanja. Neki događaji su delimično ili potpuno zaboravljeni, neki su izmenjeni, a sve je više dokaza da je moguće da su neki i "umetnuti, dodati" (Loftus, 1993; Loftus \& Pickrell, 1995).

Za to je, pre svega, bilo potrebno utvrditi da li i u kom obimu taj veran zapis odgovara događajima, onako kako su se odigrali. Sledi pregled empirijske građe koja se bavila ovim pitanjem, a koju smo pokušali da sistematizujemo po metodologiji koja je u istraživanjima korišćena.

Dnevničke studije. Pitanje tačnosti bilo je pokretačko pitanje u istraživanjima autobiografskog pamćenja, ali je metodološka "začkoljica" uvek bila- kako proveriti tačnost izveštaja o prošlim događajima. U dnevničkim studijama, subjekti prave svakodnevne dnevničke zapise o događajima, a nakon nekog vremenskog perioda proverava se na koji način se istih događaja sećaju. U jednoj takvoj studiji (Barclay \& Wellman, 1986) subjekti su vodili dnevnik tokom četiri meseca, a naknadno testirani posle dve do tri godine. Test je bio koncipiran kao test prepoznavanja: bili su izlagani različitim događajima, a prepoznavali 
su da li su ih imali ili ne u prethodnom iskustvu. Iako je procenat prepoznavanja pravih autobiografskih događaja bio visok (sa 95\% tri meseca nakon događaja pao je na $79 \%$ dve i po godine nakon događaja), i procenat lažnih prepoznavanja (subjekti su fabrikovane događaje prepoznali kao autobiografske) takođe je bio visok: ukoliko su u pitanju bile samo izmene u stvarnim događajima, u proseku 50\% takvih događaja je pogrešno prepoznavano, a ukoliko su bili u pitanju u potpunosti izmišljeni događaji, taj procenat se kretao od $20 \%$ do 25\%. U istraživanjima koja su usledila (Barclay, 1993) utvrđeno je da su ljudi češće prepoznavali kao stvarne one izmišljene događaje koji su bili u skladu sa njihovom opštom slikom o sebi, ali i po afektivnoj valenci usklađeni sa stvarnim događajima u tom periodu. Ovakvi i slični nalazi uzimaju se kao dokazi za rekonstruktivnu prirodu autobiografskog pamćenja, po kojoj "stečeno autobiografsko znanje dovodi do rekonstrukcije plauzibilnih, ali često netačnih, elaboracija prethodnih iskustava. Sećanja na većinu svakodnevnih događaja su stoga transformisana, iskrivljena ili sistematski skraćena" (Barclay, 1986, str. 89). Neki istraživači, međutim, smatraju da je ovakvo gledište suviše ekstremno, i tvrde da "sveža lična sećanja zadržavaju relativno veliki broj specifičnih tačnih informacija...ali da se, tokom vremena i pod uticajem snažnih shematski zasnovanih procesa, originalno iskustvo rekonstruiše i tako stvara novo, manje validno lično sećanje" (Brewer, 1986, str. 44). Ovakvo mišljenje Bruer potkrepljuje nalazima prema kojima se lažna prepoznavanja u veoma malom broju slučajeva (uvek ispod 5\%) odnose na događaje koji su u suprotnosti sa originalnim dnevničkim zapisima; lažna prepoznavanja događaja koji u mnogome podsećaju na stvarne događaje su pre posledica konfundiranja u samom procesu prepoznavanja nego siguran dokaz da je događaj zabeležen u memoriji u izmenjenom obliku.

Tačnost blic sećanja. Blic sećanja (flashbulb memories) su lična sećanja na iznenadne, značajne istorijske događaje (npr. atentat na Kenedija ili eksplozija Čelindžer-šatla). Prve studije ovog fenomena ukazale su na to da ispitanici imaju utisak da se tačno, do najsitnijih detalja, sećaju šta su radili i gde su bili u trenutku kada su čuli vesti o konkretnom događaju (Brown \& Kulik, 1977). Kasnija istraživanja su, međutim, uglavnom osporila ovaj utisak o nepogrešivoj tačnosti: tako su Najser i Harš (Neisser \& Harsch, 1992) prikupili detaljne pismene izveštaje ljudi o tome kako su i gde čuli vest o eksploziji Čelindžera. Kada su ih ponovo za to upitali dve i po godine kasnije, većina je tvrdila da se živo i veoma precizno seća; nijedno sećanje, međutim, nije bilo u potpunosti tačno, a više od polovine sećanja sadržalo je suštinski pogrešne navode. Ni ocena živosti ni sigurnost u konkretno sećanje nisu korelirali sa njegovom tačnošću. Kada bi blic sećanja bila tačna koliko ih pojedinac takvim doživljava, njihov sadržaj bi trebalo da se ne menja ili sasvim malo menja tokom vremena. U jednom 
istraživanju (Schmolck et al., 2000) zabeležena su blic sećanja ispitanika na presudu O.J. Simpsonu ${ }^{6}$ tri dana nakon završetka suđenja i 32 meseca kasnije. Iako je određen procenat ispitanika (29\%) dosledno izveštavao o kontekstu u kome su čuli za događaj, veći je broj ispitanika izmenio prvobitne izjave (40\% ispitanika je unelo substancijalne izmene). Tako je na primer, jedan ispitanik u prvom testiranju tvrdio da je vest video na TV-u u zajedničkoj prostoriji u studentskom domu, da su studenti neprestano ulazili i da su morali do maksimuma da pojačaju zvuk a isti taj ispitanik je 32 meseca kasnije izvestio da je za vest čuo u svojoj kući, u dnevnoj sobi, u društvu roditelja i sestre. Blic sećanja su takođe osetljiva na sadržaj samog pitanja: nakon što se jedan putnički avion zabio u stambenu zgradu u gusto naseljenoj četvrti Amsterdama, istraživači (Cronbag, Wagenaar, \& van Koppen, 1996) su pitali građane Amsterdama da li su videli na TV kako se događaj odigrao. U jednom istraživanju potvrdno je odgovorilo 55\%, a u drugom 66\%; snimak nesreće nije postojao. Jedno od mogućih objašnjenja je da su pojedinci kreirali mentalne predstave događaja na osnovu onoga što su čuli ili pročitali, i da su kasnije to interpretirali kao sećanje na snimak nesreće. Akumulirani dokazi o problematičnoj "tačnosti" blic sećanja, dovela su do toga da ih neki istraživači ne tretiraju kao poseban fenomen u okviru autobiografskog pamćenja. Ne samo sećanja na istorijski značajne ili iznenadne događaje, već da i sećanja na svakodnevne događaje mogu biti doživljena kao tačna i dugo se održavati, ako su događaji izuzetno distinktivni, lično značajni (Weaver, 1993) ili se sećanja na njih često obnavljaju (Neisser, 1982).

Svedočenja na sudu. S obzirom da su iskazi očevidaca često važan ili ključan dokaz u sudskim procesima, mnogo je naučnog truda uloženo $u$ ispitivanje tačnosti takvih iskaza $\mathrm{i}$ uslovima koji podstiču tačnost odnosno memorijske distorzije. Otkriveno je, tako, da procedura ispitivanja može doprineti tačnosti (ako su pitanja otvorenog tipa) ali i netačnim izveštajima (ako su pitanja sugestivna ili ako se ponavljaju) (Hilgard \& Loftus, 1979; Bruck \& Ceci, 1999). Identifikacija počinilaca, bilo preko fotografija ili preko direktnog prepoznavanja takođe je često pogrešna. U analizi 40 slučajeva nepravedno osuđenih počinilaca, za koje je naknadna DNK analiza utvrdila da su nevini (Wells et al., 1998) istraživači su ustanovili da je u 90\% glavni dokaz bio upravo iskaz očevica. Najverovatniji uzrok pogrešne identifikacije je relativističko prosuđivanje očevidaca: oni naime identifikuju kao počinioca onu osobu koja među prezentovanim najviše podseća na njihovu predstavu o počiniocu. Ovoj pretpostavci ide u prilog činjenica da procenat pogrešnih prepoznavanja dramatično raste ako među ponuđenim samo jedna osoba odgovara opštem opisu počinioca

\footnotetext{
${ }^{6}$ Ovo suđenje dobilo je veliki publicitet u SAD. Bivši ragbista O.J. Simpson bio je optužen za ubistvo supruge, i uprkos uverenju javnosti da je kriv, dobio oslobađajuću presudu.
} 
(npr. tamnije boje kože ili istetoviran/a), ali i dramatično opada ako se svedoci obaveste o tome da počinilac možda nije među ponuđenim osobama ili ako se ponuđene osobe prikazuju sukcesivno a ne simultano, što otežava direktno poređenje među njima (Steblay, 1997; Sporer, 1993).

Usađivanje lažnih sećanja. Sve je više dokaza u prilog tome da je, koristeći relativno jednostavne postupke, moguće ljudima usaditi sećanje na događaje koje oni nisu imali u svom iskustvu. "Usađivanje sećanja" podrazumeva da ljudi prepoznaju izmišljene događaje kao autobiografske, a u nekim slučajevima i da navode dodatne detalje u vezi sa izmišljenim događajima i na taj način ih dopunjavaju i prihvataju kao "svoje". Ovaj fenomen potvrđen je i u kvantitativnim istraživanjima asocijativnog pamćenja (Roediger \& Mc Dermott, 1995): utvrđeno je da ljudi prepoznaju reči koje im nisu prezentovane na listi reči ili se sećaju neprikazanih reči. Paralelno sa ovim istraživanjima Elizabet Loftus je sa saradnicima otpočela seriju studija u kojima se bavila ekološki validnijim problemima: svedočenjima na sudu ili u terapijskoj praksi (Loftus, 1997a, 2004; Loftus \& Bernstein, 2005; Loftus \& Pickrell, 1995). Ovi ogledi ukazali su na značaj informacije koja sledi kritični događaj (post event information) na pamćenje događaja: ukoliko su učesnici izloženi nekom dešavanju, a zatim kasnije pogrešno informisani o nekom detalju tog dešavanja (verbalno ili vizuelno, preko neautentične fotografije), u naknadnom testu češće biraju kao tačan detalj koji im je sugerisan nego onaj kome su originalno bili izloženi. Ispitanici češće greše ukoliko detalj: (a) nije od centralnog značaja za događaj; (b) ako je interval između prisećanja i događaja veći; (c) ako treba da prepoznaju među ponuđenim odgovorima a ne da odgovaraju na otvoreno pitanje i (d) ako se podstiču da aktivno rekonstruišu, zamisle događaj pre testiranja (Zaragoza \& Mitchell, 1996; Hyman \& Billings, 1998; Hyman \& Pentland, 1996). Pored efekata naknadne informacije, koja je menjala sadržaj upamćenog događaja koji su subjekti zaista doživeli, još ubedljiviji dokaz fragilnosti ljudskog pamćenja su istraživanja o usađivanju čitavih autobiografskih epizoda: ispitanici su u ovim ogledima prepoznavali kao lična sećanja događaje koji im se nisu nikada dogodili. Tako su tvrdili da su se sa pet godina izgubili u tržnom centru (Loftus \& Pickrell,1995), da su se gađali tortama na proslavi rođendana ili da ih je u zoološkom vrtu olizala kamila (Žeželj et al., 2009), da su prosuli crno vino na kumovu belu košulju ili da su se družili sa maskotom u zabavnom parku (za iscrpan pregled videti u: Reyna et al., 2007). Događaji imaju više šanse da budu uspešno usađeni ako su a. plauzibilni, odnosno ako ispitanici ocenjuju da je verovatno da su takav događaj imali u iskustvu i b. adekvatno uvremenjeni, odnosno ako su smešteni u odgovarajući vremenski interval u ličnoj istoriji (Hyman and Kleinknecht, 1999). 
Mnogo je dokaza da su deca posebno podložna uticaju naknadnih informacija i usađivanju lažnih autobiografskih događaja (Bruck \& Cecci, 1999): u seriji ponovljenih intervjua sa decom, na primer, 30-40\% dece počinje da nakon izvesnog broja ponavljanja sugestivnog pitanja (npr. Da li je gospodin koji je ušao bio nespretan?) odgovara potvrdno, i čak dodaje izmišljene detalje koji potvrđuju događaj u pravcu u kome je bio sugerisan (Ispala mu je knjiga; Bio je tako smešan kada se sapleo).

Što se tiče kvaliteta sećanja na sugerisane događaje u poređenju sa sećanjem na stvarne događaje, nalazi nisu jednoznačni: dok se u nekim ogledima (Payne et al., 1997; Žeželj et al., 2009) lažna sećanja ocenjuju kao manje pouzdana i živa, u drugim su subjekti jednako sigurni u usađene i autentične događaje (Zaragoza \& Mitchell, 1996) ili čak spremni da se opklade u jednaku sumu novca da su se usađeni odnosno autentični detalji zaista desili (Weingardt et al, 1994). Za psihološku nauku, ali i za sudsku i terapijsku praksu, vrlo je značajno pitanje Da li nezavisni posmatrači mogu razlikovati autentične od neautentičnih sećanja na prošle događaje. Kada su u jednom istraživanju (Ceci et al., 1994) kliničkim i dečijim psiholozima prikazana dečija svedočenja o pravim i lažnim događajima, oni nisu uspevali da ih uspešno razvrstaju u dve grupe. Čini se da među ovim sećanjima nema dovoljno kvalitativnih razlika da bi ih čak i iskusni istraživači diferencirali sa dovoljnom sigurnošću.

Retrospektivni izveštaji o ponašanjima $i$ doživljajima. Od ispitanika se u anketama često traži da izveštavaju o prethodnim doživljajima ili ponašanjima, a njihovi izveštaji se uglavnom uzimaju kao činjenice. U poslednje vreme sve je više pokušaja da se metodološkim korekcijama i popravi tačnost retrospektivnih izveštaja, a u tu svrhu se izučava proces transformacije sećanja: koje strategije ispitanici koriste, da li greše i da li to čine sistematski, u jednom smeru, pod kojim uslovima su skloniji greškama i kako se ta sklonost može umanjiti. Dokumentovane su različite memorijske pristrasnosti koje iskrivljavaju retrospektivne izveštaje: efekat "teleskopa" (Neter \& Waksberg, 1964; Schwartz, 2000) odnosi se na tendenciju da se skorašnji događaji datiraju ranije (utisak da su se desili pre više vremena nego što je zaista prošlo), a davni događaji datiraju skorije (utisak da su se desili pre manje vremena nego što je zaista prošlo), selektivno izostavljanje određenih događaja, oslanjanje na heuristike pri proceni intenziteta, dužine i učestalosti događaja.

Ukoliko je zadatak ispitanika da procene neko relativno retko ponašanje (dešava se manje od pet puta $\mathrm{u}$ ispitivanom periodu, recimo večera $\mathrm{u}$ restoranu u proteklih mesec dana), oni u tu svrhu koriste epizodičko prisećanje (sećaju se jednog po jednog događaja i sabiraju ukupnu frekvenciju). Ukoliko je, međutim, događaj češći od pet ili deset puta u ispitivanom periodu, raste verovatnoća da će ispitanici odustati od strategije prisećanja jednog po jednog događaja, 
i da će koristiti ono što se naziva direktnom procenom učestalosti (Burton \& Blair, 1991). Direktna procena učestalosti podložna je različitim vrstama pristrasnosti: najčešće se procene vrše uz oslanjanje na takozvani heuristik dostupnosti (eng. availability heuristic): događaji koji dostupniji u memoriji procenjuju se i kao učestaliji (Menon, 1994).

Zbog svoje direktne primenljivosti u medicini, ekstenzivno je proučavano pamćenje bolnih iskustava, najčešće na hroničnim bolesnicima. Njihovi izveštaji o intenzitetu doživljenog bola na prvi pogled ne daju jednoznačne rezultate. Pored činjenice da se prisećanja ispitanika ne podudaraju sa njihovim direktnim procenama datim u toku samog doživljaja, smer u kome greše nije uvek isti. Naprotiv, intenzitet bola se nekada precenjuje a nekada potcenjuje. Čini se da na to ima uticaja trenutni nivo bola koji subjekti osećaju (ovo se interpretira kao efekat ukotvljavanja (eng. anchoring)): oni koji trenutno trpe veliki bol skloni su da umanje prethodno doživljeni, dok su oni koji trenutno ne trpe bol skloni da ga uvećaju (Salovay, Sieber, Jobe \& Willis, 1994). 


\section{Tehnike za proveravanje tačnosti retrospektivnih izveštaja}

Kada se usvojio pristup orijentisan na tačnost autobiografskog pamćenja, potrebno je bilo razviti i tehnike kojima bi se proveravala tačnost retrospektivnih izveštaja koje dobijamo od ispitanika. U tu svrhu, istraživačima je na raspolaganju nekoliko rešenja.

Dnevnički zapisi. Kao što smo već pominjali, istraživači često porede unose neposredno nakon događaja sa izveštajima koji su vremenski značajno udaljeniji od događaja (mesecima ili čak godinama). Primarni unosi se pri tome tretiraju kao činjenice, kao standard tačnosti sa kojima se porede kasnija sećanja. Drugim rečima, nečija inicijalna, direktna reprezentacija događaja (zabeležena u dnevniku) smatra se istinitom. Iako je ovakvo zaključivanje plauzibilno, nije nužno i validno (Ross \& Buehler, 1994a, 1994b). Na primer, dve reprezentacije mogu da odslikavaju dve različite, ali jednako ubedljive slike stvarnosti (Mead, 1964). Ipak, brojni su dokazi da su memorijske greške češće i intenzivnije što je događaj vremenski udaljeniji, pa stoga ima smisla porediti neposredne i naknadne izveštaje o njemu, uz rezervu da ni prvobitni unos ne mora biti nepristrasna verzija događaja.

Poređenje izveštaja posmatrača $i$ aktera o određenoj aktivnosti. Ukoliko želimo da se oslobodimo samoprecenjujućih pristrasnosti koje možemo očekivati u izveštajima aktera, izgleda razumno da izveštaje posmatrača tretiramo kao standard za utvrđivanje tačnosti. Međutim, postoji veliki broj dokaza $u$ prilog tome da manja uključenost $u$ događaje ne podrazumeva i veću tačnost. Štaviše, izveštaji posmatrača često su manje tačni od izveštaja aktera (Ross \& Buehler, 1994; Schwarz \& Wellens, 1997). Konsenzus u izveštavanju više aktera, ili aktera i više posmatrača se sa nešto više pouzdanosti može uzeti kao mera tačnosti. Ovo pravilo se primenjuje u pravnim procedurama da bi se utvrdila verodostojnost iskaza različitih svedoka. Ni slaganje u ovim izveštajima, međutim nije garancija njihove istinitosti; neslaganje nije dokaz falsifikovanja. Nepodudarni izveštaji mogu biti rezultat različitog opažanja i razumevanja događaja.

Sećanja mogu biti i intrapersonalno konfliktna: ako je sećanje rekonstrukcija delova informacija koji potiču iz različitih izvora u jednu novu celinu, može se desiti da jedna osoba ima sećanja na događaje koji su međusobno isključivi ili protivrečni. U kontekstu izveštaja drugih kao "proksi" mere za tačnost nečijeg sećanja, međutim, nas više zanimaju interpersonalno konfliktna sećanja, odnosno situacije u kojima različiti ljudi imaju svoje verzije događaja. U jednom istraživanju (Karr, 1990) od učesnika je traženo da izveste o 
događajima iz sopstvene prošlosti za koje je utvrđeno da oni i njima bliske osobe imaju različite uspomene. Ispostavilo se da nepodudarna sećanja nisu redak fenomen: samo 15\% učesnika nije bilo u stanju da navede takav događaj. Istraživači su dalje proučavali način na koji akteri transformišu materijal (primer u Okviru 2):

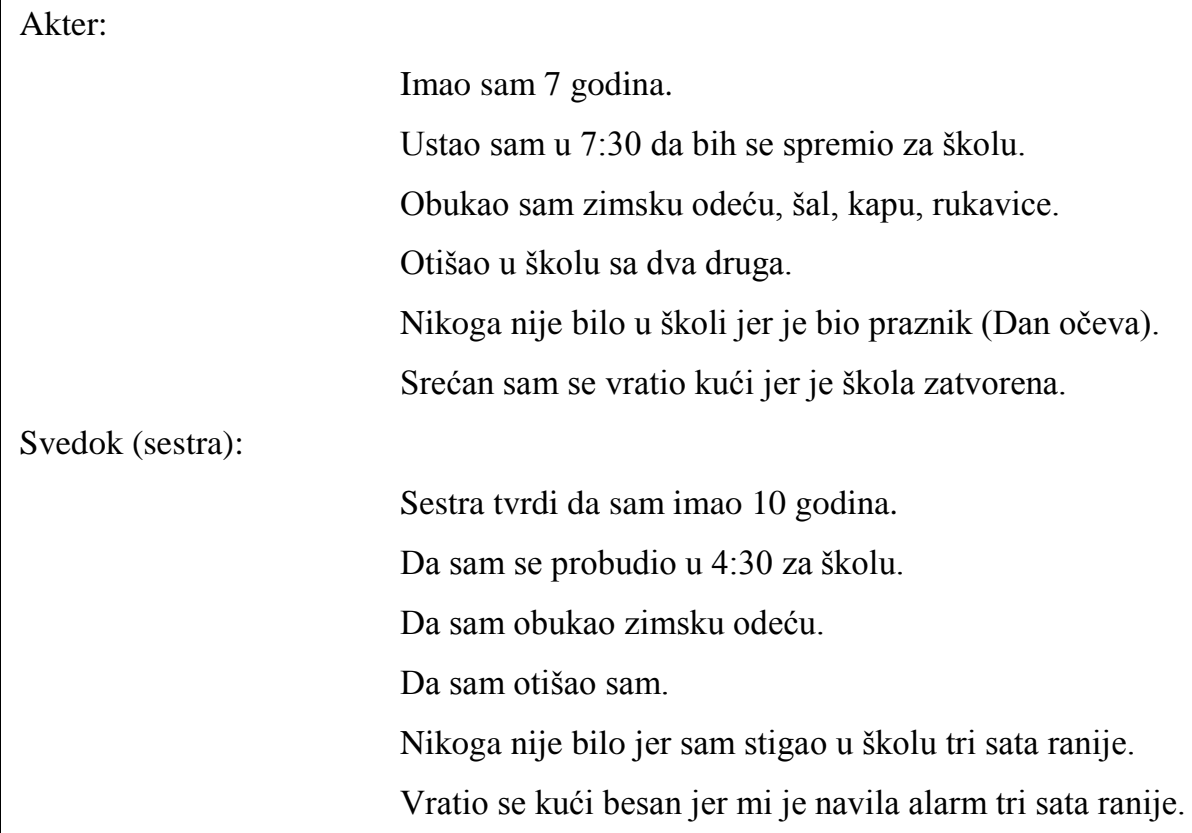

Okvir 2. Primer nepodudarnih sećanja na autobiografske događaje (Preuzeto iz Ross \& Buehler, 1994 a, str 58.)

Sećanja supružnika (parova) na njihov prvi susret takođe često otkrivaju nepodudarne detalje. Na primer, muž se seća ovakvog sleda događaja: "Sedeo sam na aerodromu čekajući da najave moj let, kada je u čekaonicu ušla jedna žena. Sela je pored mene iako je bilo mnogo slobodnih mesta. Počeli smo da razgovaramo, i ostalo je istorija". Sećanje žene na isti događaj je identično izuzev jednog detalja: ona tvrdi da je čekaonica bila sasvim popunjena i da je jedino slobodno mesto bilo pored njenog budućeg muža. Iako su često razgovarali o ovoj nesaglasnosti, i muž i žena čvrsto veruju da se sećaju tačne verzije događaja (Ross \& Buehler, 1994).

Procena "kvaliteta" evociranog događaja. Često nam broj detalja, doslednost, koherentnost i logička zasnovanost evociranog sleda događaja služe kao indikator njegove tačnosti. U tom slučajevu takozvana "narativna istina" služi nam kao proksi mera za utvrđivanje istine. Naravno, može se zamisliti da događaj može biti narativno ali ne i faktički istinit i obrnuto. Ipak, veća je verovatnoća da koherentni i dosledni izveštaji istovremeno budu u tačni. Uz konsenzus, ovo je u interpersonalnoj komunikaciji i sudskoj praksi jedan od najznačajnijih kriterijuma prema kojima procenjujemo nečiju iskrenost. 
Dokumentovani zapisi događaja. Do sada je bilo reči o posrednim kriterijumima validacije retrospektivnih izveštaja. Od toga je, naravno, pouzdanije porediti izveštaje sa objektivnim zapisima događaja. Ni ovaj kriterijum, međutim, nije garant intersubjektivne saglasnosti: $u$ zavisnosti od prirode podataka koje utvrđujemo, može biti lako ili teško utvrditi stepen podudaranja izveštaja o događaju i dokumentovanog događaja. Ako su, na primer, u pitanju objektivni parametri (npr. numerički izraženo postignuće), ova dva podatka direktno su uporediva; ako su u pitanju, na primer, procene uspešnosti, već su obojene pristrasnostima aktera i posmatrača (onih koji naknadno procenjuju dokumentovan materijal).

Kada je u pitanju konačni sud u vezi sa tim da li su autobiografska sećanja tačna ili netačna, ni akademska zajednica u tim procenama nije složna: nalazi istih studija se, naime, navode kao dokaz u prilog iznenađujućoj tačnosti i zabrinjavajućoj netačnosti. Tako se istraživanje uspomena preživelih iz koncentracionih logora (Wagenaar \& Groeneweg, 1990) navodi i kao primer podudanja prvobitnih izveštaja sa izveštajima dobijenim nakon 40 godina (Christianson, 1992), ali i kao primer pristrasnosti i selektivnog zaboravljanja (Kennedy, Mather \& Carstensen, 2004). Ovo nije usamljen primer: često citirano istraživanje u kome su pacijenti izveštavali o intenzitetu glavobolje (Hunter et al., 1979) uzima se za primer tačnosti (Linton \& Melin, 1982), ali i netačnosti (Ross \& Buehler, 1994a). 


\section{Pamćenje i slika o sebi}

\section{Funkcije autobiografskog pamćenja}

Zastupnici funkcionalnog pristupa istraživanju pamćenja (Baddeley, 1987; Bruce, 1989; Neisser, 1978) insistiraju na potrebi da se u istraživanjima uzme u obzir i kontekst u kome se odvija proces upamćivanja i prisećanja i da istraživanja pamćenja budu ekološki validnija. U jednoj često korišćenoj sistematizaciji (Pillemer, 1992) funkcije autobiografskog pamćenja podeljene su u tri kategorije: direktivna, self-usmerena i socijalna.

Direktivna funkcija. Sećanja na prošle događaje pre svega određuju standarde za mišljenja, osećanja i ponašanja u budućnosti; olakšavaju nam rešavanje problema i predviđanje ishoda događaja, ali i afektivnih odnosa kao i evaluaciju spoljne fizičke i socijalne sredine (Pillemer, 2003). U tom smislu, autobiografsko pamćenje, kao i svako drugo pamćenje je izvor znanja koji omogućava anticipaciju budućih događaja, osećanja i potreba; njegova funkcija nije vezana za prošost, već za budućnost (Nelson, 1993, 2003).

Socijalna funkcija. Najmanje očigledna, socijalna funkcija autobiografskog pamćenja je u suštini, facilitacija socijalne interakcije (Bluck, Alea, Habermas \& Rubin, 2005). Saopštavanjem ličnih iskustava daje se ubedljiviji i korisniji doprinos interakciji (Pillemer, 1992), ili iniciraju nove socijalne interakcije (Cohen, 1998). Ako delimo autobiografska sećanja sa ljudima koji u njima nisu učestvovali, dajemo korisne informacije o sebi; ukoliko ih delimo sa ljudima koji su u njima učestvovali, to doprinosi osećaju bliskosti i zajedničke istorije. Istraživanja takođe nedvosmisleno pokazuju da oštećenja epizodičkog pamćenja ozbiljno narušavaju društvene odnose osoba sa oboljenjem (Robinson \& Swanson, 1990).

Funkcija očuvanja identiteta. Lične uspomene su temelj identiteta (Mc Adams, 2003; Thorne, 2000). Doživljaj "sebe" nužno uključuje nečiju ličnu istoriju i akumulirana iskustva. Naučnici već dugo tvrde da autobiografsko pamćenje služi da obezbedi osećaj kontinuiteta i koherentnosti. Već je Viljem Džejms (James 1890/1950) istakao povratnu spregu između pamćenja i identiteta, koja postaje očigledna u slučajevima oštećenja jednog ili drugog sistema: ljudi koji pate od amnezije imaju izmenjenu sliku o sebi; oboleli od Alchajmerove bolesti često gube osećaj ličnog identiteta (Addis \& Tippet, 2004). Sa razvojem medikoterapije koja omogućava korisnicima da ponovo prežive traumatske događaje iz prošlosti i za njih asociraju druga afektivna stanja, javljaju se i etičke bojazni u vezi sa 
nepovratnom promenom njihovog ličnog identiteta, njihove autentične ličnosti i pokušaji da se uvedu normativna ograničenja za tretmane koji uključuju modifikaciju pamćenja (Liao \& Sandberg, 2008). Leon Kas, predsednik saveta za bioetiku, povodom toga je rekao da "uskratiti nekome sećanje - na događaje, ali i na osećanja koja su pratila te događaje zapravo znači uskratiti mu život i identitet" (Kaas, 2003).

Postoji nekoliko razloga zbog kojih pretpostavljamo da autobiografsko pamćenje igra ključnu ulogu u konstrukciji pozitivne slike o sebi. Potreba za stabilnošću, o kojoj je do sada bilo reči, ne implicira nužno i potrebu za pozitivnom pristrasnošću u autobiografskom pamćenju. Za većinu ljudi, međutim, stabilan identitet zapravo znači pozitivan identitet. Argument koji se nadovezuje na ovaj govori o tome da se sadržaj memorije menja u skladu sa trenutnim uverenjima i ciljevima onoga ko se priseća (Bartlett, 1932; Conway \& Pleydell-Pearce, 2000; Gramzow \& Willard, 2006; Ross \& Buehler, 1994; Singer \& Salovey, 1993). Niko, naravno, ne spori da je osnovna uloga autobiografskog pamćenja beleženje prošlih događaja, čini se da način na koji se to dešava i odstupanja u tom procesu služe slici o sebi. Postoji, dakle, potreba, a postoje i mehanizmi koji to omogućavaju.

Najser (Neisser, 1988) je tvrdio da se motivacija za svaki akt prisećanja može smestiti negde na kontinuumu između korisnosti (eng. utility), kada se prošlost koristi da se ostvari nešto u sadašnjosti, i istinitosti (eng. verity), kada se sećanje koristi da se oživi ono što se zaista dogodilo u prošlosti. Iako ne poričemo značaj istinitosti, u radu smo se fokusirali da drugu funkciju, korisnost.

Odnosom selfa i pamćenja bavile su se gotovo sve značajne psihološke škole, koristeći sopstveni konceptualni aparat. Mi ćemo pokušati da ukažemo na sličnosti njihovih zaključaka.

\section{a. Psihoanalitička perspektiva}

Frojd je pretpostavke o prirodi pamćenja i ulozi ličnih motiva u pamćenju i zaboravljanju zasnivao na dramatičnim kliničkim slučajevima koji su često uključivali patološke promene pamćenja. On je zaboravljanje interpretirao kao posledicu konflikta motiva, i uveo koncept potiskivanja. Potiskivanje je definisao kao selektivno zaboravljanje određenih značajnih životnih epizoda koje iz različitih razloga mogu biti ugrožavajuće za našu svesnu sliku o sebi (najčešće su to epizode koje imaju seksualnu konotaciju). Frojdove ideje o psihoseksualnim konfliktima kao uzrocima potiskivanja i o egu kao agensu potiskivanja temeljne su ideje njegove teorije ličnosti. 
Prema Frojdu (1922), traumatski događaj "izlaže um tako snažnoj i iznenadnoj stimulaciji da je nemoguće očekivati da će on biti obrađen i asimilovan na uobičajen način - moraju se, jednostavno, očekivati velike nepravilnosti u zapamćivanju takvih događaja" (str. 232).

Iako se najviše bavio načinom na koji se tretiraju ugrožavajući, snažno emotivno šaržirani događaji, Frojd je uočio i efekat ego-referentnosti, odnosno značajem koji dati događaji ili informacija imaju veze sa onim koji se priseća.

Setio sam se imena jednog pacijenta sa početka moje karijere tek nakon velikog napora i dugog toka asocijacija: setio sam se da se pacijent plašio slepila, onda se setio mladića koji je oslepeo u dvoboju a koji je bio blisko vezan za jednu osobu iz moje bliže okoline. Tek kada me je tok prisećanja doveo do osobe koja mi lično znači mnogo, uspeo sam da se setim tražene informacije.

Ustanovio sam da većinu mojih sećanja povezuje činjenica da su od važnosti za mene, samoreferentne (eng. self referent). Čini mi se kao da sam prinuđen da sa sobom poredim sve što čujem o nepoznatim osobama, kao da se moji kompleksi umešaju u svaku informaciju o drugima. Deluje malo verovatno da je to neka moja lična osobenost; mora biti, nasuprot, da je to način na koji ljudi obično razumevaju i pamte svet koji ih okružuje. (Freud, 1901/1917, str. 41-42).

U navedenom primeru, proces prisećanja je doveo do uspešnog ishoda tek kada je uključio samoreferentne informacije. Frojdova zapažanja o tome kako slika o sebi služi kao parametar za opažanje, vrednovanje i prisećanje događaja dobro se uklapaju u saznanja socijalne psihologije proteklih decenija.

\section{b. Socijalno-kognitivna perspektiva}

U svojoj knjizi "Sećanje: studija eksperimentalne i socijalne psihologije" Bartlet (Bartlett, 1932) je uveo koncept sheme u istraživanje pamćenja i definisao je kao aktivnu arganizaciju prošlih iskustava koja omogućava adaptivno reagovanje. Shema po Bartletu predstavlja zajedničko jezgro serije prošlih iskustava. Iskoristio je ovaj koncept da bi analizirao načine na koji ljudi pamte i dolaze do upamćenih informacija: neki spoljašnji stimulus (recimo uputstvo da se prisetite konkretnog događaja ili neki slučajno opaženi predmet) pobuđuje stav - svesno osećanje u vezi sa stimulusom, a stav aktivira shemu u okviru koje je inicijalni događaj upamćen.

Događaji se pri uklapanju u sheme (upamćivanju) i naknadnom preuzimanju iz shema (prisećanju) menjaju, apstrahuju tako da su izveštaji o događajima shematski, a ne konkretni opisi prošlog iskustva.

Iako je Bartlet priznavao da su sheme hijerarhijski organizovane, i da postoje sheme nižeg i višeg reda, nije koristio termin ego ili self da bi opisao tu hijerarhijsku strukturu. Neki autori (Greenwald, 1981) smatraju da je Bartlet zapravo odbijao da prizna postojanje 
transcedentalnog selfa, ili "čistog ega", baš kao i Viljem Džejms pre njega, a da je prihvatao činenicu da ego služi kao organizator našeg iskustva.

Pozivajući se na sheme i njihovo hijerarhijsko ustrojstvo, Bartlet je objašnjavao da proces pamćenja nikada nije prosta reprodukcija, već uvek rekonstrukcija prošlih događaja koja se odvija na tako da se evocirani događaji uklapaju u sliku o svetu oko nas i sebi.

\section{c. Geštaltistička perspektiva}

U knjizi "Principi geštalt psihologije", Kofka (Koffka, 1935) posvećuje preko 60 stranica diskusiji o ulozi ega u pamćenju. Njegovo je mišljenje da postoje dva sistema preko kojih pamtimo informacije kojima smo izloženi: ego sistem, koji pamti iskustva relevantna za sliku o sebi, i enviromentalistički sistem, koji pamti događaje irelevantne za sliku o sebi. Upamćena iskustva su međusobno povezana tako što dele istu valencu, isti "stav" odnosno dominantno osećanje. Kofkina teorija je po svojim ključnim idejama zapravo razrada Bartletovih ideja o principima pamćenja, s tim što Kofka eksplicitno naglašava da se događaji filtriraju i pamte tako da se uklapaju u sliku o sebi. Pretpostavke oba autora o "stavu" kao atributu prema kome tragovi prošlog iskustva međusobno povezuju veoma je bliska novijim istraživanjima koja se bave afektivnim tonom kao organizatorom memorije.

Zajedničko za sva tri teorijska pravca je da pretpostavljaju da se prošlost pamtimo u egocentričnoj perspektivi, odnosno da se događaja prisećamo na osnovu odnosa koje imamo prema njima.

Moderne teorije autobiografskog pamćenja polaze od veoma sličnih premisa. U okviru teorije o sistemu self-memorija (SMS; Conway \& Pleydall-Pearce, 2000; Conwey \& Holms, 2004) radna slika o sebi (eng. working self), definisana kao skup aktuelnih ciljeva i trenutno aktivnih informacija o sebi, kontroliše način na koji se formiraju, skladište i izvlače iz memorije autobiografska sećanja. Praktično to znači da će najdostupnija sećanja iz svakog životnog perioda biti sećanja u vezi sa glavnim razvojnim zadacima u tom periodu. Tako se sa aspekta formiranja identiteta objašnjava takozvani efekat reminiscencije, odnosno činjenica da većina ljudi najbolje pamti događaje iz ranog zrelog perioda (kasne adolescencije i ranog odraslog doba): to je, naime, period u kome se uobličava identitet osobe i tokom kojeg osobe imaju najviše razvojnih zadataka, pa time i najviše generativnih sećanja. Vilsonova i Ros u svojoj teoriji takođe pretpostavljaju da se autobiografska sećanja evociraju $\mathrm{u}$ odnosu na aktuelnu sliku o sebi (eng. current self), s tim što se u većoj meri bave motivisanim a ne generativnim pamćenjem. Oni, naime smatraju da se sećanja o sebi strateški evociraju i menjaju tako da odgovaraju trenutnoj predstavi koju imamo o sebi; to može biti uslovljeno potrebom za doslednošću, ali i potrebom za opažanjem promene, 
napretka. Ova dva autora pretpostavljaju da strateške intervencije u pamćenju zapravo služe da nam omoguće zadovoljavajuća poređenja sa aktuelnom slikom o sebi i da predstavljaju deo šire strategije samoprecenjivanja. Tome doprinosi i subjektivno lociranje događaja $u$ vremenu, o kome je već bilo reči: naime, neuspehe doživljavamo kao udaljenije, a uspehe kao bliže sadašnjem trenutku, iako se objektivno mogu locirati u isti vremenski period (Wilson \& Ross, 2003). Na taj način se mi distanciramo od prethodnih, neuspešnih ja, sa kojima poredimo aktuelno ja. Ova strategija dakle deluje isključivo ako se događaj koji se evocira opaža kao dovoljno udaljen da omogućava "bezbedno" poređenje. 


\section{Egotizam pamćenja}

\section{Kada se i kako modifikuje pamćenje}

Kada jednom znamo da izveštaji koje smo od subjekata dobili o događajima u njihovoj prošlosti ne odgovaraju realnosti, već su na određen način izmenjeni, možemo postaviti i sledeća dva pitanja: (1) Na koji način je došlo do izmene zapamćenog, i (2) U kojoj fazi procesa se ova modifikacija desila.

Kada govorimo o procesima pristrasnog pamćenja, postoje dve logičke mogućnosti: (a) selektivno upamćivanje odnosno zaboravljanje određenih događaja, i (b) iskrivljavanje-izmena zapamćenog sadržaja. Ova dva procesa nisu međusobno isključiva - naprotiv, često su u sadejstvu. Neki događaji se izostavljaju, a neki modifikuju i to često sa istim ciljem, o kome će biti reči kasnije. Barik (Bahrick, 1985; Bahrick, Hall \& Dunlosky, 1993; Bahrick, Hall \& da Costa, 2008) razlikuje tri tipa obrade upamćenog materijala: replikativni, konstruktivni i rekonstruktivni. Replikativno prisećanje je doslovno sećanje dobro savladanog (eng. overlearned) materijala, na primer jednostavnih aritmetičkih zadataka; konstruktivno prisećanje je organizovanje epizodičkog sadržaja na osnovu semantičkih shema, na primer, sećanje opšteg tona, suštine (eng. gist) nakon čitanja pasusa u knjizi; dok rekonstruktivno prisećanje podrazumeva sistematsku distorziju zapamćenog sadržaja, na primer u svedočenju o saobraćajnoj nesreći konkretni događaji bivaju izmenjeni, i to na različite načine u zavisnosti uloge koju je konkretan učesnik imao u njima. Razlika između konstruktivnog i rekonstruktivnog prisećanja je u tome što rekonstruktivno podrazumeva sistematsku izmenu sadržaja, koja je najčešće motivisana. Drugi autori koji se bave istom tematikom (Gramzow \& Willard, 2007), pod rekonstruktivnim prisećanjem podrazumevaju proces koji Barik zove konstruktivnim, a Barikovo rekonstruktivno prisećanje nazivaju motivisanim prisećanjem. U ovom tekstu se pod rekonstrukcijom podrazumeva svaka vrsta prisećanja koje nije doslovna reprodukcija (u skladu sa osnovnim Bartletovim terminom), a motivisane izmene nazivaju se egotizmom pamćenja ili motivisanim/sistematskim distorzijama.

U odgovoru na drugo pitanje moguće je pretpostaviti da se modifikacija desila (a) pri kodiranju informacija, odnosno u fazi zapamćivanja- u tom slučaju, selektivno i pristrasno opažanje situacije dovodi do zapamćivanja jednih, a ignorisanja drugih informacija, odnosno do pojačavanja jednih a umanjivanja drugih. Moguće je, međutim, i (b) da pristrasna 
pretraga memorije dovodo do selektivnog prisećanja (izveštava se, na primer, samo o događajima koji potvrđuju pozitivnu sliku o sebi, ali ne i o onima koji je osporavaju) ili modifikacije zapamćenog. Ukoliko se eksperiment dizajnira tako da se ispitanicima informacija za koju očekujemo da će izazvati pristrasnost plasira nakon što se događaj odigrao, onda se sa većom sigurnošću može govoriti o pristrasnoj pretrazi. Na primer, nakon što saslušaju listu atributa izvesne imaginarne grupe adolescenata, jednoj grupi ispitanika kaže se da je u pitanju navijačka grupacija a drugoj da je u pitanju grupa mladih izviđača. Prva grupa setiće se značajno više atributa koji ukazuju na agresivnost nego druga. Ili, nakon što saslušaju uopšten opis izvesne ženske osobe po imenu Beti, jednoj grupi ispitanika se kaže da je Beti sada srećno udata, a drugoj da je Beti postala lezbejka. Prva grupa ispitanika setiće se da je Beti u srednjoj školi izlazila sa momcima, a druga da Beti nije pokazivala te vrste sklonosti (Snyder \& Uranowitz, 1978). U oba ova slučaja, naknadno aktivirani stereotipi utiču na selektivnu pretragu memorije, koja rezultira selektivnim prisećanjem. Ukoliko, međutim, postoji incijalna preferencija za jednu vrstu informacija, kao što je to čest slučaj ukoliko su informacije ego-referentne, onda je nemoguće naknadnom intervencijom izazvati selektivnu pretragu, i u takvim situacijama je teže eksperimentalno razdvojiti ova dva procesa. Pored toga, u ovom istraživanju nas upravo i zanimaju distorzije sui generis, odnosno one koje se dešavaju spontano, bez naknadnih eksperimentalnih intervencija.

Precenjivanje prošlih postignuća je posebno zanimljiva forma memorijske pristrasnosti, zato što se ne može jednostavno objasniti selektivnim pohranjivanjem ili selektivnim pristupom pozitivnim informacijama u memoriji. Ako ljudi, na primer, sistematski navode veći skor na testu nego što su ga dobili, kako to objasniti? Tu se ne radi o sudu formiranom na osnovu selektivnih informacija (npr. mislim da sam odlično uradio test jer se sećam samo pogodaka). Ako neki skor teži da bude precenjen, mora biti negde zabeleženo, zapamćeno, koji je tačan skor. Kada dolazi do izmene upamćenog? Da li je jedino moguće objašnjenje za ovu vrstu greške zapravo svesno obmanjivanje?

Teorija nejasnog traga (eng. fuzzy trace theory, Brainerd \& Reyna 1990; 2001) nudi moguće alternativno objašnjenje ovog fenomena. Ova teorija predstavlja takozvani dualni model pamćenja i rezonovanja, i polazi od nekoliko osnovnih premisa: a. u memoriji postoji doslovni (lat. verbatim) i sržni, suštinski (eng. gist) zapis (trag) događaja; oba ova traga postoje istovremeno, b. doslovni i suštinski trag se paralelno, a ne serijalno pohranjuju pri zapamćivanju (dakle, nije u pitanju akumuliranje doslovnih tragova u kratkoročnoj memoriji iz kojih se apstrahuje nadređeni, suštinski trag) i (c) moguće je nezavisno se prisetiti doslovnog i suštinskog traga događaja. U skladu sa pretpostavkom o kognitivnoj štednji, očekuje se da 
ljudi preferiraju nejasnu, kvalitativnu obradu informacija. Drugim rečima, ako nisu motivisani da se ponašaju drugačije, oslanjaće se na upamćene sržne informacije (Brainerd \& Reyna, 2002; 2004). U slučaju greške preterivanja, to bi značilo da postoji doslovan trag o postignuću, ali i sržni trag koji bi postignuće interpretirao kao npr. uspeh odnosno neuspeh i dodelio mu određen raspon, kao odgovor na pitanje: Gde se moj skor nalazi na distribuciji postignuća u odnosu na ostale (pri vrhu, iznad proseka, ispod proseka i slično). Pamćenje raspona skorova svakako je fleksibilnije nego pamćenje konkretnog skora, odnosno ima veću marginu greške i dozvoljava više pozitivnog odstupanja. Pored toga, što je događaj vremenski udaljeniji, više je kognitivne energije potrebno utrošiti na pristup doslovnom tragu, odnosno veće su šanse da se oslonimo na suštinski memorijski trag događaja. Ova teorija ne objašnjava zbog čega je pristrasnost u sećanju pozitivna, već postulira mogući mehanizam prisećanja koji "drži" reprodukovani sadržaj u očekivanim marginama. Dalje u tekstu biće reči o tome zbog čega su odstupanja obično u sopstvenu korist.

\section{Kako pristrasnosti u pamćenju služe ličnim ciljevima}

"Sećanje ima svoju posebnu istinu. Ono odabira, izbacuje, menja, uvećava, umanjuje, hvali i kudi i na kraju stvara svoju sopstvenu stvarnost, svoju raznovrsnu ali obično doslednu verziju događaja, i nijedno razborito ljudsko biće ne veruje u nečiju drugu verziju više nego u sopstvenu."

S. Rushdie

Najser smatra da pamćenje treba posmatrati kao vrstu cilju usmerene aktivnosti: "Pamćenje je vrsta delanja. Kao i druge vrste delanja, cilju je usmereno, lično i posebno: (1) cilju usmereno zato što zadovoljava određene ciljeve onoga koji se priseća; često je taj cilj da se kaže istina o nekom prošlom događaju, ali u drugim slučajevima to može biti da se zabavi, impresionira ili ohrabri (2) lično je zato što nosi lični pečat, odgovara načinu na koji osoba koja se priseća radi, opaža i razgovara. (3) Posebno je zato što se dešava u specifičnom kontekstu, i odražava specifične prilike i zahteve koji taj kontekst nameće" (Neisser, 1996, str.204).

Za nas je u ovoj diskusiji od značaja konstatacija da je prisećanje je zavisno od motiva onoga ko se seća, i od zahteva situacije u kojoj se prisećanje odvija. Motiv može biti što tačnija rekonstrukcija događaja u cilju što tačnije samospoznaje, ali i zaštita ega od nekih ugrožavajućih 
saznanja, ili pak sticanje ili održavanje ugleda pred drugima. Na koji način se čovek služi sećanjem da bi svoj ego osnažio ili zaštitio? Neki autori (Greenwald 1981; Sedikides \& Green, 2004) smatraju da je pristrasnosti u pamćenju moguće grupisati u tri kategorije:

a. egocentrizam (ego i sve što je u vezi sa njim ima primarni status u organizaciji sećanja)

b. blagonaklonost prema sebi (odgovornost za uspehe ali ne i za neuspehe, selektivno pamćenje uspeha, poboljšavanje rezultata...)

c. kognitivni konzervativizam (neprihvatanje promene, izuzev ako nije pozitivna promena).

Da ne bi bilo terminološke zabune, sva ova tri mehanizma dovode do greške koju smo nazvali egotizam: egotizam u oblasti sećanja bi bila greška tipa:"ljudi se sećaju sebe onakvim kakvim bi želeli da su bili".

Grinvald (Greenwald, 1980) uočava sličnost između ovih pristrasnosti i mehanizama pomoću kojih totalitarne države kontrolišu protok informacija. U svom opisu idealne totalitarne države, na primer, Hana Arent zaključuje: "Kada bi se kreirao idealan svet prema totalitarnim merilima, neuspesi se ne bi beležili, priznavali i pamtili" (Arendt, 1951/1998, str 388). I u Orvelovoj "1984", objašnjava se da je trening pamćenja način kontrole prošlosti: "Neophodno je zapamtiti da su se događaji desili na željeni način. I ako je neophodno preurediti nečije sećanje ili malo doterati pisane izveštaje, onda to treba uraditi i zaboraviti da je urađeno. Ovaj trik je moguće naučiti kao bilo koju mentalnu tehniku... Zove se duplomišljenje" (Orwell, 1949/1964, str. 176). Čitav niz eksperimenata sprovedenih 50 i više godina kasnije osmišljen je tako da proveri ove pretpostavke; najčešće se u ovim eksperimentima poredilo pamćenje materijala koji je bio od značaja ili nije bio od značaja za sliku o sebi (Grinvald (Greenwald 1981;1999) to naziva "egocentričnom perspektivom").

Pristrasno pamćenje učestalosti i sadržaja prošlih ponašanja i doživljaja. Već je bilo reči o tome koliko su pouzdani izveštaji ovog tipa, a sada treba videti da li se sistematski greši u jednom pravcu, koji nam donosi pozitivne informacije o sebi. Ego-osnažujuće pristrasnosti ispoljavaju se i u ovom domenu: ljudi su skloni da potcenjuju učestalost socijalno nepoželjnih ponašanja (konzumacija alkohola i cigareta), a precenjuju učestalost socijalno poželjnih (čitanje knjiga, održavanje higijene - tuširanje ili pranje zuba). Pri tome, pristrasnosti ove vrste su izraženije ukoliko su događaji (a) vremenski udaljeniji (za retka ponašanja, za koje važi strategija epizodičkog prisećanja) i (b) učestaliji (za česta ponašanja, čije se "prisećanje" u stvari svodi na procenu i bliže je shematskoj nego epizodičkoj memoriji). Ispitanici navedeni da veruju da su pranje zuba (Ross, McFarland, \& Fletcher, 1981 ) ili konzumacija 
kofeina ( Sherman \& Kunda, 1989 ) loši za zdravlje izveštavaju o manjoj učestalosti pranja zuba i pijenja kafe u poređenju sa ispitanicima koji su navedeni da veruju da su ista ponašanja dobra za zdravlje. Ispitanici navedeni da veruju da je introverzija poželjna osobina generisali su više autobiografskih događaja koji su ih prikazivali kao introvertne, dok su oni navedeni da veruju da je ekstraverzija poželjna generisali događaje koji ih prikazuju kao ekstravertne osobe (Sanitioso et al., 1990).

Prisećanja na doživljeni bol, takođe se često transformišu upravo u smeru koji odgovara aktuelnoj slici o sebi i potrebi za samoprecenjivanjem: u jednom često citiranom istraživanju (Norvell, Gaston-Johansson \& Fridh, 1987) žene su procenjivale bol koje su osećale tokom tri faze porođaja. Nakon nekoliko dana, od njih je traženo da se prisete intenziteta bola. Utvrđeno je značajno potcenjivanje. Iako autori ovaj efekat prvenstveno objašnjavaju nekongruencijom raspoloženja u toku i nakon porođaja (strah i anksioznost naspram olakšanja i sreće), čini se da postoje i dodatni faktori koji ga mogu objasniti. Naime, ovakvo umanjenje istovremeno i adaptivno: pre svega, olakšava ponovno preuzimanje rizika, odnosno odluku o novoj trudnoći porođaju. Bedli duhovito napominje "Svakako se može pretpostaviti da vrste koje zaboravljaju kako je porođaj zaista bolan imaju više šanse da procvetaju nego vrste kod kojih je sećanje na bol izuzetno živo i dugotrajno" (Baddley, 1999, str.120). Pored toga, čini se da je u našem društvu socijalno neprihvatljivo žaliti se na proces donošenja deteta na svet, a izveštaji o sopstvenom bolu mog da ukazuju na centriranost na sebe umesto na dete. U prilog ovom gledištu o tome da trenutno raspoloženje nije jedini faktor koji doprinosi ovakvoj "ružičastoj proceni" idu i nalazi o tome da se fenomen potcenjivanja porođajnog bola pokazao robustnim: iako je osetljiv na trenutno raspoloženje ispitanica, ipak se javlja i kod onih koji su u pozitivnom i kod onih koji su u negativnom raspoloženju.

Pristrasno lociranje događaja u vremenu. Lični narativi ljudi, njihova autobiografska sećanja slični su po tome što su uređeni prema hronološkom principu. Hronološki red daje koherentnost i značenje nečijoj životnoj priči (Landau, Greenberg, \& Sullivan, 2009). Naš aktuelni identitet uključuje uverenja o tome kako smo se razvijali vremenom, kakvi smo bili i kako smo postali ovakvi kakvi smo danas. Značaj događaja za sliku o sebi, živost sećanja i njegova valenca mogu uticati na subjektivnu procenu vremena (Ross \& Wilson, 2002). Kada od ispitanika tražimo da se navedu tačne datume, poređaju događaje u sekvencijalni poredak (Skowronski, Walker, \& Betz, 2003) ili ih smeste u autobiografske odeljke (rano detinjstvo, osnovna škola, fakultet), oni u tom procesu često greše. Za sliku o sebi je još relevantnija psihička udaljenost događaja, operacionalizovana kao odgovor na pitanje: Koliko vam se događaj X čini bliskim ili dalekim (Wilson, Gunn \& Ross, 2009). Odstupanja ove procene 
od objektivne vremenske udaljenosti nekog događaja govore nam zapravo o tome koliko ljudi žele da im je određen događaj blizak ili dalek, odnosno koliko se ono što taj događaj govori o njima uklapa u aktuelnu predstavu sebe. Niz eksperimenata (Ross \& Wilson, 2002; Wilson, Gunn \& Ross, 2009) potvrdio je pretpostavku da će ljudi procenjivati pozitivne događaje kao subjektivno bliske, a negativne kao subjektivno udaljene, bilo da su to prave autobiografske epizode (npr. proslava mature, koju su oni koji su sa ponosom govorili o svom socijalnom statusu u srednjoj školi doživljavali mnogo bližom nego oni koji su se sećali sebe kao usamljenog i neprihvaćenog), ili eksperimentalno izazvani pozitivni odnosno negativni događaji, kao što je uspeh ili neuspeh na testu (Sanna, Chang, \& Carter, 2004). Uz to, istraživanja pokazuju da se grupe koje se inicijalno ne razlikuju prema nivou samopoštovanja, razlikuju nakon što se jednostavnom eksperimentalnom manipulacijom ${ }^{7}$ navedu da se osećaju blisko odnosno udaljeno od uspomene na prošle uspehe (Gebauer, Broemer, Haddock, \& von Hecker, 2008). Sličan mehanizam pristrasnog lociranja događaja u vremenu registrovan je i kada su u pitanju grupe kojima pripadamo, posebno ukoliko čine važne odrednice socijalnog identiiteta. Tako, na primer, današnje generacije Nemaca, otprilike dve ili tri generacije udaljene od počinilaca Holokausta, doživljavaju Holokaust kao subjektivno udaljeniji ako ih u eksperimentu podsete na sve njegove strahote, a kao subjektivno bliži ukoliko su u eksperimentu obavešteni o naporima koje je nemačka država ulagala da ispravi nepravde i oduži se žrtvama (Peetz, Gunn, \& Wilson, 2010). S druge strane, kada je zadatak ispitanika da oceni subjektivnu udaljenost "tuđih" autobiografskih događaja (poznanika ili grupe kojoj ne pripadamo), ova pristrasnost se ne ispoljava: valenca događaja ne utiče na njihovo lociranje u vremenu (Ross \& Wilson, 2002). Čini se da ljudi vrlo kreativno manipulišu doživljajem udaljenosti događaja koji su od značaja za sliku o sebi ili značajnim grupama. Ovaj mehanizam, za razliku od manipulacije sadržajem događaja, nije osetljiv na "korekciju objektivne stvarnosti", pošto je u pitanju doživljaj udaljenosti koji niko ne može da ospori.

Pristrasne atribucije: viđenje prošlih događaja kao očekivanih a neuspeha kao neizbežnih. Iako ova grupa pristrasnosti ne spada direktno u pristrasnosti pamćenja, odlučili smo se da je prikažemo zato što je važna za organizaciju događaja u autobiografskoj memorijit i pripisivanje opšteg tona tim događajima. U reinterpretaciji prošlosti, važno je objasniti uzroke za prošla dešavanja. U tom procesu ljudi često greše u svoju korist. Tako je, na primer, dobro dokumentovana iluzija neizbežnosti (eng. hindsight bias, Fishoff \& Beyth,

\footnotetext{
${ }^{7}$ Obeležavanjem krajeva vremenske ose: u jednom slučaju ona počinje rođenjem, a u drugom sa 16 godina.
} 
1975; Fishoff, 1982) - sklonost ljudi da precenjuju verovatnoće prošlih događaja - veruju da je ono što se desilo bilo neizbežno, a uz to veruju i da su takav ishod i sami očekivali. Ova je pojava registrovana u različitim domenima, od medicinskih dijagnoza (Arkes, Wortmann, Saville, \& Harkness, 1981) i sudskih presuda (Kamin \& Rachlinski, 1995) do rezultata izbora (Leary, 1982; Sanna, Schwarz \& Small, 2002; Sanna \& Schwarz, 2003) i sportskih događaja (detaljnije u Hawkins \& Hastie,1990). Dobiti od ovakve reinterpretacije prošlosti su očigledne: ljudi se osećaju kompetentnije, sredina se doživljava kao podložna kontroli, a neizvesnost od budućnosti umanjuje (Campbell \& Tesser, 1983; Hawkins \& Hastie, 1990). Ova sklonost, međutim, zavisi od poželjnosti ishoda događaja za onoga ko se priseća: nekoliko ogleda (Louie, 1999; Louie, Curren, \& Harich, 2000) potvrdilo je da su učesnici koji su obavešteni o pozitivnim ishodima događaja ispoljili iluziju neizbežnosti i pripisali sebi zasluge za uspešan ishod ("znali su sve vreme da će se desiti dobre stvari"), dok učesnici obavešteni o negativnim ishodima nisu ispoljili iluziju neizbežnosti i odbijali da preuzmu odgovornost za neuspešan ishod ("nismo mogli da predvidimo pa stoga nismo ni odgovorni"). Učesnici u virtuelnoj igri berze koji su odlučili da ne kupe neke akcije, a njihova cena je porasla nisu zaključili da je ishod bio predvidiv, dok su oni koji su kupili iste akcije došli do takvog zaključka (Louie, 1999). Radnici koji su otpušteni kao tehnološki višak iz jedne fabrike procenili su da je taj događaj bio znatno manje predvidljiv nego što su to procenili radnici koji nisu otpušteni i sugrađani koji nisu imali direktne veze sa događajem (Mark \& Mellor, 1991.). U nekim istraživanjima utvrđena je i naizgled suprotna sklonost, nazvana "retroaktivnim pesimizmom" (Tykocinski, 2001; Tykocinski et al., 2002): u određenim okolnostima ljudi su upravo neuspehe videli kao neizbežne. Autori je, međutim, interpretiraju kao još jednu od strategija koja služi očuvanju pozitivne slike o sebi: ne misleći o boljim alternativama, ljudi se oslobađaju odgovornosti za neuspeh ("šta god da sam uradio, nisam mogao da promenim ishod"). Ovakvom tumačenju ide u prilog i činjenica da su optimisti znatno skloniji korišćenju ove strategije nego pesimisti (Aspinwall \& Brunhart, 1996; Sanna \& Chang. 2003; Scheier et al., 1989). U kojim slučajevima, dakle, nepovoljan ishod biva interpretiran kao predvidiv, a u kojim kao nepredvidiv? Prema jednom integrativnom tumačenju (Pezzo, 2007), pošto je negativan ishod ugrožavajući za onoga ko se priseća, on je motivisan da ga pripiše spoljnim razlozima. Ukoliko je u tome uspešan, doći će do izražene iluzije neizbežnosti (takozvanog retroaktivnog pesimizma); ako je, međutim, teško naći spoljne razloge za neuspeh, on će se opaziti kao nekontrolabilan (neće doći do iluzije neizbežnosti). 
Bolje pamćenje ličnih pozitivnih atributa naspram tuđih pozitivnih atributa. Rezultati brojnih eksperimenata (D'Argembeau, Comblain \& Van der Linden, 2005; Rogers, Kuiper \& Kirker, 1977; Sedikides \& Green, 2000, 2004; Sedikides, Green \& Pinter, 2004) upućuju na to da su ljudi skloniji da upamte pozitivne atribute u opisu sopstvene ličnosti, dok su kod opisa drugog naprotiv pristrasni u drugom smeru i bolje pamte negativne atribute, iako je $\mathrm{u}$ ovom smeru razlika manje izražena. Ovaj efekat ostaje robustan čak i kada se kod ispitanika formira pozitivno očekivanje od imaginarnog drugog (na osnovu inicijalnog pozitivnog opisa njegove ličnosti, ispitanici procenjuju kako bi se imaginarna osoba ponašala u različitim situacijama). Isto tako, efekat je repliciran i kada se uzela u obzir slika o sebi koju imaju ispitanici: i oni sa pozitivnim i negativnim samopoimanjem lošije su pamtili negativni od pozitivnog fidbeka. Ovo autori uzimaju kao potkrepljenje za ideju o motivisanom pamćenju. Preciznije, registrovana pozitivna pristrasnost $\mathrm{u}$ pamćenju ličnih atributa nije rezultat pozitivnijih očekivanja koje imamo o sebi (racionalnog, nemotivisanog kognitivnog procesa), niti rezultat izloženosti neusklađenom fidbeku, nego rezultat potrebe da se zaštitimo od ugrožavajućih informacija odnosno očuvamo pozitivnu sliku o sebi (motivisanog pamćenja).

Bolje pamćenje sopstvenih doprinosa grupnim aktivnostima. U jednom ogledu (Brenner, 1973 ) ispitanici su naglas, jedan po jedan, čitali pojmove koji su im izlagani. Iako su znali da će u naknadnom testu biti proveravana upamćenost svih reči, mnogo bolje su pamtili reči koje su sami čitali nego koje su čitali drugi, a lošije od proseka reči koje su čitali njihovi prethodnici ili naslednici u nizu. Ros i Sikoli (Ross \& Sicoly, 1979) utvrdili su da su ljudi u stanju da navedu više aktivnosti kojima su lično doprineli radu u grupi nego aktivnosti kojima su drugi doprinosili, i da se značajno brže prisećaju svojih doprinosa. U jednom prirodnom eksperimentu, svaki od supružnika bio je u stanju da navede više svojih "domaćinskih" aktivnosti tokom proteklih nedelju dana; u laboratorijskim uslovima, ljudi su bolje pamtili sopstvene izjave u diskusijama i precenjivali procenat sopstvenog učešća u njima. Autori ove nalaze objašnjavaju većom pažnjom koju akteri poklanjaju sopstvenim u poređenju sa tuđim aktivnostima, a koja dovodi do i do njihovog boljeg upamćivanja, pa time i precenjivanja sopstvenih doprinosa. Ne isključuju, međutim, ni uticaj favorizovanja sećanja koja im idu u prilog, odnosno doprinose boljem viđenju sebe.

Bolje pamćenje informacija koje potkrepljuju naše stavove. U klasičnom eksperimentu Levina i Marfija (Levine \& Murphy, 1943) utvrđeno je da su ispitanici sa prosovjetskim stavovima bolje upamtili informacije koje prikazuju Sovjete u pozitivnom svetlu, dok su ispitanici sa antisovjetskim stavovima bolje upamtili informacije koje Sovjete prikazuju negativno. Autori smatraju da njihovi nalazi potvrđuju takozvanu hipotezu usklađivanja (eng. 
congeniality hypothesis): pristižuće informacije obrađujemo, pamtimo i prisećamo ih se tako da odgovaraju našim postojećim uverenjima i stavovima. Ovaj ogled poslužio je kao inspiracija nizu sličnih, od kojih su neki potvrdili (Jones \& Aneshansel, 1953) hipotezu usklađivanja, dok su neki rezultati upravo govorili suprotno (Kulesa, 1999; Eagly et al., 2000). U svojoj metaanalizi, Iglijeva je sa saradnicima (Eagly, Kulesa, Chen \& Chaiken, 2001) utvrdila da je efekat usklađivanja po pravilu dobijan u starijim eksperimentima, sa manje rigoroznom metodologijom i slabijim merama prisećanja. Ona, međutim, nije zaključila da stavovi nemaju uticaja na proces pamćenja: naprotiv, smatra da je u slučaju izlaganja prostavskom i kontrastavskom materijalu moguće koristiti alternativne kognitivne odbrambene strategije: moguće se, s jedne strane, izbegavati ili lošije pamtiti kontrastavske informacije, ali je moguće i pažljivo obrađivati upravo kontrastavske informacije i aktivno im kontraargumentovati, pripremajući se tako za eventualnu odbranu sopstvenih stavova- ovo bi se moglo nazvati strategijom spontane inokulacije (Eagly, Chen, Chaiken \& Shaw-Barnes, 1999). Čak i ako prihvatimo ovo tumačenje, iako nalazi o pamćenju kontrastavskog materijala još uvek nisu jednoznačni, još uvek ostaje validna pretpostavka o uticaju potrebe da zadržimo koherentnu sliku sveta (potvrdimo postojeće stavove) na pamćenje i prisećanje.

Greška usklađivanja (eng. bias in recall). Ispoljava se kao tendencija da se o prošlim stavovima i ponašanju izveštava kao da su usklađeni sa aktuelnim stavovima i ponašanjem. Ovo je fenomen prvi put uočen u političkom ponašanju, kada je $u$ anketama primećeno da nakon izbora veći procenat ljudi od registrovanog izveštava a. da je izašao na izbore $i b$. da je glasao za vladajuću stranku. Da bi se ovaj fenomen rasvetlio, osmišljeno je longitudinalno istraživanje $\mathrm{u}$ kome je registrovano glasačko ponašanje ljudi u tri izborna ciklusa (Himmelweit, Biberian \& Stockdale, 1978). Ustanovljene greške u prisećanju nisu bile slučajne: ljudi su većinom usklađivali svoje prethodno ponašanje sa aktuelnim (izveštavali su o tome da su i na prethodnim izborima glasali za stranku za koju su glasali na aktuelnim). U eksperimentalnim studijama takođe je primećeno da se ljudi sećaju svojih stavova kao doslednih, odnosno da ih usklađuju sa trenutnim stavovima. U jednoj takvoj studiji, Šerman je sa saradnicima (Sherman et al., 2008) testirao i retestirao stavove ljudi prema različitim medicinskim tretmanima (presađivanje organa, korišćenje stome za hranjenje, korišćenje veštačkih pluća) u razmaku od godinu dana. Ispitanici su promenili otprilike četvrtinu stavova. Od ukupnog broja ljudi koji su promenili stavove, njih $75 \%$ se pogrešno sećalo prvobitnih stavova, i to tako da odgovaraju aktuelnim. 


\section{Zašto dolazi do pristrasnosti u autobiografskom pamćenju?}

Načelno, greške u autobiografskom pamćenju mogu doprinositi: a. regulaciji afekta, b. očuvanju pozitivne slike o sebi i c. očuvanju pozitivne slike o grupama kojima pripadamo. Pokušaćemo da ilustrujemo na koji način one doprinose ostvarivanju ova tri cilja.

Regulacija afekta. Rukovođeni principom prijatnosti, pravimo selekciju između pozitivnih i negativnih životnih događaja. Istraživači koji se bave proučavanjem afektivnog tona autobiografskih sećanja zaključuju da ljudi generalno teže da evociraju veći broj prijatnih nego neprijatnih sećanja, da se prisećaju događaja pozitivnije nego što su ih iskusili i da je intenzitet pozitivnih afekata pripisanih sećanjima snažniji nego negativnih (Levine, Lench \& Safer, 2009). Rezimirajući studije koje su se bavile afektivnim tonom autobiografskih sećanja, u svojoj studiji nazvanoj "Život je prijatan- i sećanja pomažu da ostane takav! ", Volker, Skovronski i Tompson (Walker, Skowronski \& Thompson, 2003) navode da se između 50 i 60\% životnih događaja procenjuje kao pozitivno, a 25 do 30\% kao negativno (Grafikon 1) daje sumarni pregled niza studija). Ovaj efekat dobija se i kada se prisećanje odvija u situaciji senzorne deprivacije (Suedfeld \& Eich, 1995), čime se isključuje alternativno objašnjenje da je posledica suptilnih sredinskih znakova koji služe kao "okidači" prijatnih sećanja; takođe se dobija i u situaciji "nevoljnog" prisećanja, kada ispitanici nemaju direkciju da pretražuju po autobiografskoj memoriji, već tokom dužeg vremenskog perioda unose dnevničke beleške o sećanjima koja se spontano javljaju (Berntsen, 1996). Pored brojnosti jednih i drugih sećanja, utvrđeno je da afektnivni ton pozitivnih sećanja mnogo sporije opada u intenzitetu nego afektivni ton negativnih sećanja. Drugim rečima, krivulja slabljenja afekata u memoriji (eng. fading affect bias) strmija je za neprijatne događaje (Walker, Skowronski \& Thompson, 2003; Walker \& Skowronski, 2009). 


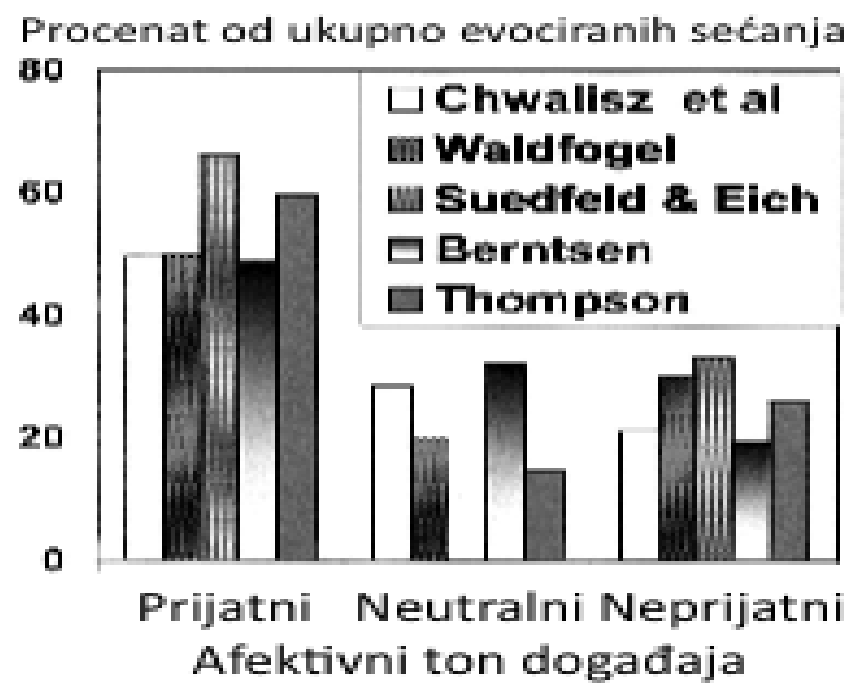

Grafikon 1. Učestalost autobiografskih sećanja prema afektivnom tonu (preuzeto iz Walker, Skowronski \& Thompson, 2003).

S obzirom da negativni imaju potencijal da izazovu nelagodnost, da uznemire ili zastraše, da bi se održalo osećanje opšte dobrobiti, verovatnoća njihovog reevociranja treba da bude manja nego verovatnoća prisećanja pozitivnih događaja. Ljudi tragaju za pozitivnim, a izbegavaju negativna iskustva. Ovo je bazična premisa mnogih psiholoških teorija: pamćenja (Taylor, 1991), ličnosti (Freud, 1920/1952) i rezonovanja (Festinger, 1997). Higgins (1997) opisuje ovu bazičnu motivaciju pozivajući se na dva jednostavna hedonistička principa: promocije i prevencije (užitak u prijatnim i izbegavanje neprijatnih doživljaja).

Da je regulacija afekta u osnovi ove vrste pristrasnosti, govore istraživanja u kojima se ispitanici instruirani da se usredsrede na svoje emotivno stanje prisećaju prošlih događaja kao pozitivnijih nego što su ih sami zabeležili u trenutku dešavanja, dok je kod onih koji su instruirani da se što tačnije prisete prošlosti, ovaj efekat značajno manje izražen (Kennedy, Mather \& Carstensen, 2004). Istraživanja takođe ukazuju da su stariji ljudi skloniji pozitivnoj selekciji sećanja (Mather, 2004). Autori smatraju da su ove uzrasne razlike posledica usavršenijih strategija za kontrolu afekata kod starijih ispitanika.

Hipoteza o mobilizaciji- minimizaciji koju je predložila Šeli Tejlor (Taylor, 1991) u interpretaciji reagovanja na pozitivne odnosno negativne događaje polazi od potrebe za ravnotežom: suočen sa negativnim događajem, organizam mobiliše resurse za odgovor (mobilizacija ovog intenziteta najčešće nije potrebna za pozitivne događaje). Da bi se vratio $\mathrm{u}$ homeostazu, organizam zatim aktivira suprotne procese. Tejlorova to naziva minimizacijom. Minimizacija se dešava na biološkom, kognitivnom i socijalnom planu, i 
obično je intenzivnija za negativne nego za pozitivne događaje. Drugim rečima, negativni događaji izazivaju snažnije afektivne reakcije, ali i snažniji napor organizma da neutrališe njihove posledice, što se u pamćenju ispoljava kao brže slabljenje negativnih nego pozitivnih afekata. Mehanizam potiskivanja negativnih afekata u ovom kontekstu viđen je kao pozitivna, adaptivna reakcija kojom se održava stanje ravnoteže i ublažavaju efekti intenzivnih emocija.

Očuvanje pozitivne slike o sebi. Pored potrebe za regulacijom emocija, prisećanje prošlih događaja često je pod uticajem motiva da se očuva ili poboljša slika o sebi.

Sedikides i Grin (Sedikides \& Green, 2004; 2008) analizirajući ovu ulogu memorijskih grešaka, razlikuju samozaštitnu i samoafirmišuću motivaciju. Prva je usmerena na zaštitu slike o sebi od neprijatnih, potencijalno ugrožavajućih saznanja, dok je druga usmerena na afirmisanje sopstvenih prednosti i dobrih osobina. Posledica dejstva samozaštitne motivacije su selektivno zaboravljanje, umanjivanje značaja i izmena sadržaja negativnih događaja tako da budu prihvatljiviji za sliku o sebi; posledice dejstva samoafirmišuće su selektivno pamćenje, davanje na značaju i izmena sadržaja pozitivnih događaja tako da ulepšavaju sliku o sebi.

Ros i Vilsonova (Ross \& Wilson, 2003; Wilson \& Ross, 2003) pokazali su kako sistematske promene u autobiografskom sećanju mogu služiti slici o sebi koju trenutno imamo. Prema ovim autorima, osoba vođena trenutnim viđenjem sebe, sistematski pretražuje pamćenje u želji da potkrepi tu sliku, a u nekim slučajevima i da stekne utisak o sopstvenom napretku. U osnovi ove strategije je očekivanje doslednosti ili pozitivne promene, pa u krajnjem ishodu, pozitivne i koherentne slike o sebi. Slično razmišlja i Džonson sa kolegama (Johnson 2006; Johnson \& Sherman, 1990) kada tvrdi da naša uverenja utiču na način na koji interpretiramo upamćene događaje. Još se snažnije pristrasnost tog tipa može očekivati ako su uverenja o sebi, a događaji autobiografski.

Očuvanje pozitivne slike o grupi kojoj pripadamo. Motiv samoprecenjivanja ne odnosi se isključivo na lična postignuća i lične atribute, već i na postignuća i atribute grupa kojima pripadamo (najčešće), sa kojima se identifikujemo i koje visoko vrednujemo (Fiske, 2004). Prema teoriji socijalnog identiteta (Tajfel \& Turner, 1986) naš identitet je značajnim delom određen pripadnošću različitim socijalnim grupama. Odnos prema sopstvenoj grupi je dakle istovremeno i odnos prema sebi.

Može se, stoga, pretpostaviti da će se iste pristrasnosti u pamćenju kao i u slučaju lične ego uključenosti javiti i u slučaju grupne (Baumeister \& Hastings, 1997): 
- po istom principu po kome se u pamćenju favorizuju ego relevantne informacije, favorizuju se i informacije relevantne za grupu

- selektivno se pamte informacije u vezi sa grupom: pozitivne imaju više šanse da budu upamćene i reprodukovane u poređenju sa negativnim

- uspesi grupe se uvećavaju, a neuspesi umanjuju.

U istraživanjima pamćenja sadržaja u vezi sa sopstvenim i tuđim grupama dobijen je snažan efekat valence: nakon izlaganja jednakom broju pozitivnih i negativnih ponašanja pripisanih članovima svoje i tuđe grupe pamti se značajno više pozitivnih informacija o svojoj, a negativnih o tuđoj grupi (Howard \& Rothbart, 1980). U jednom istraživanju koje se bavilo sećanjem na rat u Iraku (Lewandowsky, Stritzke, Oberauer \& Morales, 2005) istraživači su utvrdili da se u američkom uzorku znatno veći procenat ispitanika netačno sećao da je pronađeno oružje za masovno uništenje, dok je u australijskom i nemačkom uzorku takvih ispitanika bilo zanemarljivo malo. Pretpostavka istraživača bila je da je ovakvo sećanje dozvoljavalo ispitanicima da lakše konstruišu uverenja kojima opravdavaju vojnu intervenciju u Iraku. Ako su naša uverenja o zajedničkoj prošlosti u skladu sa perspektivom socijalne grupe kojoj pripadamo, to može dovesti do povećanja socijalne bliskosti i koherencije i stvaranja osećaja zajedničke stvarnosti (eng. shared reality, Hyman, 1994, 1999).

Značajni događaji iz prošlosti se preoblikuju tako da pružaju opomenu, ali i inspiraciju daljem razvoju zajednice: glavni zadatak društvenog pamćenja postaje unutrašnje povezivanje zajednice i stvaranje opštih vrednosti i slike sveta (Halbwachs, 1992). Države obično prepoznaju značaj formiranja jedinstvenog kolektivnog pamćenja, pa se u taj proces uključuju institucije, mediji, školski programi, a na suptilniji način i jezičke konstrukcije koje se favorizuju i smatraju prihvatljivim (na primer, korišćenje zamenice mi ili naš kada se govori o nacionalnoj grupi). Istraživači kolektivnog pamćenja u bivšoj SFRJ (Đerić, 2009) ukazuju na selektivno pamćenje i zaboravljanje u okviru dominantnog narativa "narodnooslobodilačke borbe". Jednostavna podela osnovnih uloga u njemu ("narod" i "narodni neprijatelj"), uprkos kasnijim osporavanjima, čini se da je još uvek na snazi. Tako, kao odgovor na pitanje "Ko je zaslužan za pobedu u drugom svetskom ratu u Jugoslaviji?", 28\% populacije odgovara "Partizani", 7\% navodi sopstvenu nacionalnu grupu ("Srbi"), a 5\% poseže za neodređenim, kolektivnim akterom ("Narod") (Manojlović-Pintar, 2011). Centriranost na sopstveni grupni okvir vidljiva je i iz datiranja događaja: tako $41 \%$ populacije 
tvrdi da je Drugi svetski rat trajao od 1941. do 1945., a manji broj navodi 1939. kao godinu početka rata. Isti fenomeni, samo na nivou pojedinačnih država nastalih iz SFRJ, zabeleženi su u interpretaciji ratova iz 90tih godina. Tako je u populaciji Srbije i dalje najviše onih koji misle da je "Srbija uvek vodila samo oslobodilačke ratove" (70\%) i da je "Srbija u svim ratovima koje je vodila u poslednjih 200 godina bila na pobedničkoj strani" (51\%). Iako kao pojedinačnu ličnost koja je najodgovornija za rat navode Slobodana Miloševića (50\%), narod koji smatraju najodgovornijim je "drugi": Hrvati (70\%) i Slovenci (33\%) (Stojanović, 2011). Koliko je državama značajno da nametnu jedinstveno viđenje događaja iz prošlosti, govori i činjenica da većina evropskih država ima Zakone o pamćenju, koji se najčešće odnose na zabranu negiranja holokausta ili zabranu poređenja holokausta sa drugim zločinima, priznavanje ropstva kao zločina protiv čovečnosti, ali i definisanje uloge sopstvene države u kolonijalizmu, na primer (fr. Loi Rapatries, zakon o kolonijalizmu, tražio je da školski programi priznaju "pozitivnu ulogu" Francuske u afričkim kolonijama, ali je posle protesta imigrantskih grupa i akademskih krugova istoričara i nastavnika istorije morao biti izmenjen). U zemljama nastalim iz bivše Jugoslavije, većina parlamenata donela je deklaracije o ratovima devedesetih kojim je želela da reguliše interpretaciju prošlosti i kolektivno sećanje (Koren, 2011). Te deklaracije postaju istorijski izvor, i u javnom diskursu često se tretiraju kao objektivna zabeleška dešavanja: kao što se dnevničke beleške u istraživanjima individualnih sećanja porede sa naknadno evociranim sećanjima na iste događaje, tako se ove deklaracije uzimaju kao standard za evaluaciju sećanja pojedinca na određene istorijske događaje.

Pored favorizovanja sopstvene grupe, u percepciji grupa javlja se još jedna specifična pristrasnost koji se naziva homogenizacija (eng. homogeneity bias): tuđe grupe opažaju se kao homogenije, odnosno njihovi članovi kao međusobno sličniji (Judd \& Park, 1988; Ostrom \& Sedikides, 1992). Ovaj fenomen javlja se i u procesu pamćenja i prisećanja informacija u vezi sa tim grupama. Za grupe kojima pripadamo pamte se subordinirani atributi, a za grupe kojima ne pripadamo superordinirani atributi, kao posledica grublje kategorizacije (Park \& Rothbart, 1982): tako će, na primer, žene češće pamtiti pozitivne događaje u kojima su učestvovale žene, ali i profesiju, godine i opis fizičkog izgleda drugih žena, dok će ređe pamtiti pozitivne događaje čiji su akteri muškarci, i za njih će pamtiti manje dodatnih atributa (isto, naravno, važi i za muškarce - u pamćenju favorizuju sopstvenu grupu, i pamte je uključivši veći broj kategorija). Kada se pamte stavovi koje navodno poseduju članovi grupa kojima pripadamo, pamte se i stavovi koje delimo i po kojima se razlikujemo; kod članova tuđih grupa pamtimo 
samo stavove po kojima se razlikujemo (Harring \& Gaertner, 1992). Dalje, pri opisivanju događaja u kojima su akteri članovi tuđih grupa javlja se fenomen nazvan mizantropsko sećanje (eng. misantropic memory, Ybarra \& Stephan, 1996): neprihvatljiva ponašanja se opisuju apstraktnim terminima, dispozicijama, a pozitivno vrednovana ponašanja se opisuju konkretnim terminima (ukazuje na atribuciju- dispozicionu u prvom, a situacionu u drugom slučaju). Drugim rečima, pripadnici tuđih grupa imaju manju šansu da im se pripiše zasluga za pozitivna ponašanja i ova ponašanja imaju manju šansu da budu zapamćena nego negativna ponašanja. Ono što je zanimljivo je da ovaj fenomen, međutim, nestaje ako su u pitanju članovi grupa kojima pripadamo ${ }^{8}$ ! (Ybarra, Stephan \& Schaberg, 2000).

Nalazi o favorizovanju sopstvene grupe u pamćenju potvrđeni su čak i u paradigmi minimalnih grupa (Howard \& Rothbart, 1980; Gramzow, Gaertner \& Seidikides, 2001). Minimalnim grupama nazivaju se grupe eksperimentalno formirane na osnovu nekog irelevantnog obeležja (boje očiju ili kose, sposobnosti pamćenja besmislenih slogova ili apstraktnih vizuelnih simbola) ili čak isključivo slučajnosti (bacanjem novčića).

Zakonitosti o kojima je reč, a koje predviđaju pristrasnosti u pamćenju informacija u vezi sa sopstvenom grupom potvrđuju se i ako je pamćenje isključivo na nivou prepoznavanja: brže i tačnije identifikujemo lica pripadnika sopstvene nego tuđih grupa (Corenblum \& Meissner, 2006).

Gramzov i saradnici (Gramzow, Gaertner \& Sedikides, 2001) smatraju da je logično očekivati da se zapamćene informacije o grupama kojima pripadamo podvrgavaju istom pristrasnom tretmanu kao i informacije o sebi, s obzirom na tesnu povezanost slike o sebi i slike o grupama kojima pripadamo, na činjenicu da je samovrednovanje delimično izvedeno iz vrednovanja grupa kojima pripadamo (Tajfel \& Turner, 1986; Luhtanen \& Crocker, 1992): tako su negativne informacije o sopstvenim grupama ugrožavajuće, a pozitivne osnažujuće za lično samopoštovanje.

\footnotetext{
${ }^{8}$ Kako je ovaj fenomen blizak korespodentnoj pristrasnosti (bivšoj fundamentalnoj grešci atribucije), s obzirom da je u pitanju tuđe, a ne sopstveno ponašanje, očekivalo bi se da mizantropsko sećanje opstane u tim uslovima.
} 


\section{Da li je pristrasno pamćenje vrsta socijalne kognicije?}

Da li je proučavanje uticaja motivacije na pamćenje, konkretno uticaja ego uključenosti na pozitivno iskrivljavanje autobiografskih sećanja još uvek u domenu socijalne kognicije?

Činjenica je da se u poslednje vreme granice između istraživačkih predmeta različitih grana psihologije zamagljuju, ako ne i gube. Sve je više zajedničkih metodoloških oruđa, ali i teorijskih koncepata koji bivaju pozajmljeni i izučavani u okviru druge, do skora sasvim nezavisne paradigme. Ovako formulisan, problem našeg istraživanja može se posmatrati kao zajednički problem psihologije ličnosti, kognitivne psihologije i socijalne psihologije.

Pamćenje, kao fundamentalni kognitivni proces, jedna je od centralnih tema kognitivne psihologije; slika o sebi i autobiografska sećanja kao centar stabilnog identiteta proučavaju se u psihologiji ličnosti; odnos kognitivnih procesa i motiva, kognitivne pristrasnosti u opažanju sebe i drugih uglavnom je u domenu socijalno-kognitivnih istraživanja. Predmet proučavanja socijalne kognicije definiše se pomoću polova: od selfa do kulture (Fiske \& Taylor, 2008). Samosaznavanje se posmatra kao prvi i osnovni oblik socijalnog saznanja. Mentalne reprezentacije selfa, samoregulacija, motivi i samoregulacija - to su tačke preklapanja između psihologije ličnosti i socijalne kognicije. Pored toga, pristrasnosti koje ispoljavamo u odnosu na sebe vrlo često ispoljavamo i u odnosu na grupe kojima pripadamo ili želimo da im pripadamo.

Dalje, motivi koji utiču na modifikaciju pamćenja mogu biti lični, ali i socijalni (ugled, status), a način na koji se eksperimentalno izazivaju najčešće je direktno preuzet iz relevantnih socijalno-psiholoških eksperimenata. Na kraju, pored tehnika izučavanja pamćenja i prisećanja, preuzetih velikim delom iz kognitivne psihologije, veliki broj tehnika preuzima se iz oblasti socijalne percepcije - istraživanja opažanja drugih i pamćenja aktivnosti drugih, i primenjuju na opažanje sebe i pamćenja sopstvenih aktivnosti. 


\section{Da li je tendencija ka samoprecenjivanju putem prekrajanja sećanja obmanjivanje ili samoobmanjivanje?}

"Učinio sam to", tvrdi moje sećanje. "Nije moguće da sam to učinio" - kaže moj ponos, i ostaje nepopustljiv. Na kraju, sećanje popušta.

F. Nietzsche

Odgovor koji psihološka nauka daje na pitanje "Da li su pojedinci svesni da na ovaj način manipulišu svojim sećanjem", odnosno "Da li imaju kontrolu nad tim procesima", najčešće je negativan, ili barem delimično negativan.

S jedne strane, postoji nekoliko solidno utemeljenih empirijskih nalaza koji ukazuju na to da nije u pitanju svesna strategija prekrajanja zapamćenog:

a. Pristrasnosti se javljaju u privatnom kao $i$ u javnom kontekstu. Dve značajne pregledne studije (Weary, 1978; Sedikides \& Gregg, 2008) bavile su se (a) tendencijom za preuzimanje odgovornosti za povoljne, a izbegavanjem odgovornosti za nepovoljne događaje (eng. self serving bias) i (b) tendencijom ka samoprecenjivanju (eng. self enhancement bias): pamćenje sopstvenih uspeha kao značajnijih i izrazitijih nego što su bili i umanjivanje neuspeha kao neznačajnih i minornih. Iako su se u većini eksperimenata ove pristrasnosti mogle objasniti tendencijom da se ostavi povoljan utisak na druge, u nemalom broju eksperimenata nedvosmisleno su dokumentovane pristrasnosti i u privatnom okruženju (ispitanicima obezbeđena potpuna anonimnost ili se podaci o kojima izveštavaju ne čuvaju).

b. Pristrasnosti se javljaju i uz jak pritisak ka iskrenosti. Kada se u ogledima koriste instrumenti (poligraf, lažni cevovod i slično) za koje subjekti veruju da registruju neiskrene odgovore, pristrasnosti se i dalje javljaju. $\mathrm{U}$ jednom od takvih eksperimenata (Riess, Rosenberg, Melburg \& Tedeschi, 1981), polovina subjekata navedena je da poveruje da je dobila odlične rezultate na navodnom testu socijalne inteligencije. Drugi su obavešteni da su im rezultati daleko ispod proseka. Zatim su u jednoj eksperimentalnoj grupi učesnici uvereni da aparat bez greške detektuje netačne odgovore, u drugoj im je rečeno da je aparat prilično nepouzdan, a u trećoj im nije ništa rečeno o aparatu. U sve tri grupe ispitanika, javila se atribuciona pristrasnost (pripisivanje odgovornosti za uspeh sebi - sopstvenoj socijalnoj kompetenciji, a za neuspeh lošem testu); u sve tri grupe, takođe, ispitanici su izveštavali o značajno višem skoru na testu nego što im je saopšten, a ova tendencija bila je izraženija u neuspešnoj nego u uspešnoj grupi. 
c. Vreme odgovaranja u slučaju pristrasnih odgovora isto je ili kraće nego u slučaju nepristrasnih. Ako bi u pitanju bila svesna strategija prekrajanja odgovora, ona bi zahtevala dodatni mentalni napor i produžavala vreme reakcije. Studije (npr. Brecker \& Greenwald, 1981), međutim, pokazuju, da je vreme reakcije isto ili kraće kod pristrasnih odgovora u poređenju sa onim odgovorima kod kojih se pristrasnost ne registruje.

d. Ljudi se ponašaju u skladu sa pristrasnim procenama. Ukoliko sebi pripišu odgovornost za uspešno izvedene zadatke, ljudi će biti uporniji u njihovom rešavanju. Ako pamte prošle uspehe u nekoj aktivnosti, radije će se u nju upuštati u budućnosti (Greenwald, 1997).

S druge strane, postoje dokazi o tome da su pristrasnosti u pamćenju izraženije u određenim situacijama:

(a) Veliki broj istraživanja pokazuje da su sve tri grupe pristrasnosti u pamćenju u vezi sa egom pojačane u slučaju ego uključujućeg (involvirajućeg) konteksta. Uključenost (eng. involvement) pojačava egocentrizam u pamćenju i blagonaklonost prema sebi u pamćenju' : bolje se pamte sadržaji kojima se pripisuje veći lični značaj (Greenwald,1981); što su događaji značajniji, veće su šanse da budu modifikovani.

(b) Što je sadržaj koga se prisećaju manje dostupan u pamćenju, veća je šansa da se ispolje sve tri vrste pristrasnosti (Willard \& Gramzow, 2008).

(c) Što je situacija koje se prisećaju nejasnija, veća je šansa da se ispolje sve tri vrste pristrasnosti (Kunda, 1990).

Čini se se za sada može govoriti o sadejstvu motiva (za tačnošću i samoprecenjivanjem pred sobom ili pred drugima) u pojavi pristrasnog prekrajanja prošlosti - i da se mogu donekle specifikovati situacije u kojima se očekuje veća izraženost ovih pristrasnosti. Korekcije koje ljudi čine nad zapamćenim materijalom, međutim, ostaju u granicama koje situacija dozvoljava: ako ljudi imaju opravdanja za izmene, oni su spremniji i da ih čine. Što je događaj koga se prisećamo udaljeniji, slabije dostupan, lakše je i prilagoditi ga sopstvenim ciljevima. Slično rezonuje i Kunda koja tvrdi da "kada osoba izvodi određeni zaključak koji

\footnotetext{
${ }^{9}$ Konzervativizam, odnosno opiranje promeni, takođe je izraženiji u situacijama od većeg ličnog značaja. Ovaj nalaz uglavnom potiče iz eksperimenata sa promenom stavova a ne iz eksperimenata sa proverom pamćenja (Kunda, 1990). Jedna struja persuazivnih ogleda, međutim, ukazuje na upravo suprotan efekat uključenosti a ova nedoslednost je, u stvari, posledica načina na koji je operacionalizovana uključenost (vidi Johnson \& Eagly, 1989; 1990, opsežnu metastudiju o uticaju uključenosti na promenu stava; za operacionalizaciju tipova uključenosti vidi Žeželj, 2006).
} 
joj ide u prilog, istovremeno se oseća obaveznom da konstruiše i opravdanje za njega koje bi se činilo smisleno i potencijalnom nepristrasnom posmatraču" (Kunda, 1990, str. 492 ). I naše istraživanje će pokušati da eksperimentalno izazove ove motive u različitom odnosu (pretpostavićemo da u nekim situacijama dominira motiv za tačnošću, a u drugim za samoprecenjivanjem), a zatim će registrovati da li se pristrasnosti javljaju i da li se ponašaju na očekivan način. Ukratko ćemo prikazati kako se uobičajeno provociraju motiv za samoprecenjivanjem (samopredstavljanjem) i motiv za tačnošću u sličnim eksperimentalnim nacrtima.

\section{Motivi za samopredstavljanjem/samoprecenjivanjem naspram motiva za tačnošću}

Takvi nacrti obično uključuju dve situacije koje se razlikuju po tome što je jedna u većoj meri privatna, a druga javna. U njima se polazi od pretpostavke da prisustvo publike, odnosno svest o tome da smo predmet posmatranja, utiče na potrebu za emitovanjem pozitivne slike o sebi. Uopšteno se može reći da što je neko ponašanje više izloženo javnosti, važnije je za sliku o sebi i verovatnije je da će se javiti intenzivnije samopredstavljanje (Baumeister, 1986;1998; Havelka, 2008). Pored stepena javnosti (broja ljudi koji mogu prisustvovati, videti ili čuti o nečijem ponašanju), na samopredstavljanje utiče i vrsta publike pred kojom se predstavljamo: publika koja je višeg statusa, atraktivnija i akteru sličnija provocira i snažniju potrebu da joj se dopadnemo (Schlenker \& Pontari, 2000; Schlenker, 2009). Uz to, što je socijalna situacija značajnija za pojedinca, što su značajnije posledice neuspešnog ili dobiti od uspešnog samopredstavljanja, ova potreba je snažnija (Beck, 2003; Leary \& Kowalski, 1990).

S druge strane, rezultati eksperimentalnih studija upućuju i na to da postoje situacije u kojima želja za samopredstavljanjem gotovo i da ne postoji (Burušić, 2007). To su: a. situacije u kojima je primarni cilj obaviti posao, izvršiti zadatak, b. situacije u kojima je nemoguće kontrolisati ekspresiju emocija (intenzivan bes, tuga i slično), c. rutinske socijalne interakcije i d. okolnosti u kojima je akteru od interesa da suzbije samopredstavljanje (terapijske seanse, iskreni prijateljski razgovori).

U poslednje vreme se sve više proučava i u kojoj meri samopredstavljanje zahteva ulaganje kognitivne energije, a time, posredno, i koliko je proces samopredstavljanja kontrolisan od strane aktera (Baumeister, 2003; Pontari \& Schlenker, 2001). Ovo se najčešće ispituje 
uvođenjem nekog zadatka koji ima za cilj da angažuje kognitivne resurse (pamćenje višecifrenog broja ili nekog drugog podatka; rad pod strogim vremenskim ograničenjem) i ispitivanjem razlika između ovako opterećene eksperimentalne grupe, i kontrolne grupe koja se neopterećeno samopredstavlja. Razlika među grupama ukazuje na potrebu za angažovanjem kognitivnih resursa u samopredstavljanje, odnosno svesnu manipulaciju slikom o sebi; ukoliko razlika među grupama ne postoji, moglo bi se zaključiti da je samopredstavljanje delimično ili potpuno automatizovano, odnosno da ne zahteva svesni napor pojedinca.

Ako govorimo o procesu prisećanja, kontekst u kome se prisećanje odvija može uticati na javljanje pristrasnosti i intenzitet pristrasnosti: ako je (a) situacija javnija, (b) publika značajnija, i (c) sadržaj u većoj meri involvirajući za ispitanika, motiv za samopredstavljanjem je snažniji i veće su šanse da do pristrasnosti dođe. 


\section{Značaj ispitivanja memorijskih pristrasnosti i uloge motivacije u prisećanju}

Retrospektivni izveštaji se često koriste kao izvori podataka o različitim psihičkim procesima, iako je njihova validnost osporavana u početnim fazama razvoja metodologije (James, 1890/1950; Freud, 1922). Verbalni retrospektivni samoizveštaji služili su i služe kao oruđe za razumevanje vrednosti, uverenja, stavova, atribucija, emocija, pamćenja, motiva i kao osnova za predviđanje budućeg ponašanja. Iz perspektive količine informacija, sećanje na sopstvena ponašanja ili stanja trebalo bi da bude najtačnije: akter, za razliku od posmatrača, raspolaže većom količinom informacija i ima dužu vremensku perspektivu. S druge strane, akteru je teško da sebe sagleda objektivno, odnosno da odvoji motivaciju od kognicije u ovom slučaju.

U pregledu koji sledi nemamo ambiciju da predstavimo potpunu listu oblasti u kojima se psiholozi oslanjaju na retrospektivne izveštaje, već samo nekoliko oblasti koje su u tom domenu posebno "osetljive". S druge strane, nećemo se ograničiti na izveštaje o sopstvenim postignućima, odnosno na procene sopstvenih sposobnosti, iako je to domen u kome smo eksperimentalno proučavali pojavu motivisanih memorijskih distorzija.

Sećanje na traumatske događaje. Većina istraživanja koja se bavi posledicama zlostavljanja u ranom detinjstvu ili izloženosti snažnoj traumi kasnije tokom života (boravak u zatvoru, logoru, zlostavljanje od strane supružnika) sled događaja rekonstruiše na osnovu sećanja samih aktera. Ne čudi, stoga, što se tačnost ovih podataka često dovodi u pitanje (Briere \& Conte, 1993; Delia Femina, Yeager, \& Lewis, 1990; Herman \& Schatzow, 1987; Kruttschnitt \& Dornfeld, 1992; Loftus, 1993; Williams. 1994; Wildom, Spatz \& Robin, 1996). Nedostatak dokumentacije koja bi omogućila objektivnu kvalifikaciju stepena zlostavljanja, na primer, onemogućava proveru ove hipoteze u ekološki validnijoj situaciji, a istovremeno i predstavlja razlog zbog koga se istraživači oslanjaju na retrospektivne izveštaje. U jednoj od retkih studija u kojoj su registrovane žrtve zlostavljanja (71 štićenik Sigurne kuće, žrtve "okrutnog i nasilnog oca"), 30 godina nakon toga samo 31\% izveštava o tim događajima u intervjuu. Ostali negiraju takvo iskustvo. U jednom relativno novijem istraživanju (Delia Femina, Yeager \& Lewis, 1990) praćena je grupa delikvenata koji su sa otprilike 15 godina proveli godinu ili više dana u zatvoru u Konektikatu. Više od polovine (53\%) intervjua sprovedenih 10 godina kasnije, sadržalo je suštinski različite navode od onih zabeleženih u 
njihovim dosijeima. Većina izmena išla je u pravcu umanjivanja traumatičnosti događaja. U ranije pomenutom istraživanju koje se bavilo sećanjima na zlostavljanje u koncentracionim logorima (Wagenaar and Groeneweg, 1990), ispitanici su se nakon 40 godina začuđujuće dobro sećali nekih situacija, konteksta, pravila života u logoru, ali su neki od njih zaboravili čitave traumatične epizode $\mathrm{u}$ kojima su bili žrtve, umanjivali njihov intenzitet, nisu prepoznavali svoje mučitelje na fotografijama iz tog perioda ili njihova imena (njihova detaljna svedočanstva data su u Okviru 3).

Svedok P.C 1947 izvestio je o tome kako je čovek umro u njegovoj baraci. Sledeći dan, zapovednik logora De Rijke ušao je i izneo telo bez i malo poštovanja, kao da je reč o uginuloj životinji. Godine 1984 zaboravio je čitav događaj i ne prepoznaje ni ime ni fotografiju De Rijke-a.

Stražar Daahluizen fizički je zlostavljao svedoka J. D. i to toliko da ovaj nije mogao da obavlja bilo kakav posao narednih godinu dana. U intervjuu 1984 J.D. se nije sećao imena Daahluizen.

Svedok L van der M. 1947 detaljno opisuje kako ga je De Rijke brutalno tukao duže vremenske periode i tokom nekoliko dana, u toj meri da nije mogao da stane na noge danima posle. U intervjuu 1984 seća se da ga je samo povremeno «gurkao». Isti svedok je prisustvovao ubistvu logoraša jevrejskog porekla, i o tome precizno svedočio 1947. 1984. godine ovaj događaj je u potpunosti zaboravio.

Svedok G.S. u inicijalnom intervjuu izveštavao je o tome kako su stražari Diepgrond i Booxmeer udavili jednog zatvorenika u buretu sa vodom. Toga se nije sećao 1984, i čak je porekao da je tako nešto ikada izjavio.

Okvir 3. Neslaganja retrospektivnih izveštaja o zlostavljanju u logoru (preuzeto iz Wagenaar and Groeneweg, 1990)

Izveštaji o konzumaciji alkohola, psihoaktivnih supstanci ili lekova. U terapiji zavisnika, često se u nedostatku objektivnijih mera, kao kriterijum evaluacije uzimaju samoizveštaji ispitanika o konzumaciji alkohola, droga ili vremenu i novcu utrošenom na kockanje. U poređenju sa izveštajima bliskih srodnika, izveštaji pacijenata o konzumaciji alkohola u nekom defiinisanom vremenskom periodu najčešće govore o manjoj učestalosti i obimu ovog ponašanja (Del Boca \& Darkes, 2003). Ovo ne mora biti samo svesno obmanjivanje 
terapeuta; naprotiv, i ovaj nalaz se ponavlja, iako manje izražen, i u slučaju da se pacijenti anonimno izjašnjavaju. Moguće je da je posledica greške u rekonstrukciji (oslanjanje na utisak i njegovu naknadnu kvantifikaciju). ali činjenica da se disproporcija utvrđuje u istom smeru (pacijenti dosledno izveštavaju da piju ređe i manje nego što to tvrde ljudi iz njihove neposredne okoline), može da ukaže da je u pitanju motivisana distorzija. U slučaju korišćenja psihoaktivnih supstanci, krvne analize mogu dati objektivne podatke. Ovi su podaci, međutim, ograničeni na određen vremenski period, a i ova vrsta praćenja zahteva značajne finansijske resurse. Posmatranje u prirodnom okruženju takođe je teško izvodljivo. Stoga samoizveštaj ostaje najčešće korišćena mera. Istraživanja u kojima je proveravana tačnost izveštaja ispitanika o korišćenju narkotika ne daju dosledne rezultate: neka ukazuju na precenjivanje (Skog, 1992) a druga na potcenjivanje (Poikolainen \& Karkkainen, 1983). U slučaju patoloških kockara, objektivni testovi uopšte nisu dostupni, pa je samoizveštaj zapravo jedina mera na raspolaganju, koju eventualno možemo validirati izveštajima ljudi iz neposredne okoline (Hodgins \& Makarchuk, 2003). Iako samoprocene količine izgubljenog novca i vremena provedenog u kockanju značajno koreliraju sa procenama drugih, ipak je utvrđeno da se u samoizveštajima dosledno umanjuje i jedno i drugo.

Medicinski profesionalci se u proceni efikasnosti propisane terapije takođe oslanjaju na izveštaje pacijenata. Nekada je moguće objektivno registrovati unos lekova i uporediti sa tako dobijenim podacima. U jednom istraživanju (Milgrom et al., 1996), deca hronično obolela od astme izveštavala su o korišćenju inhalatora sa kortikosteroidima u periodu od 13 nedelja. $\mathrm{Na}$ inhalatorima je postojao elektronski merač koji je takođe beležio učestalost korišćenja. Iako su bili svesni da će njihovi izveštaji biti kontrolisani, pacijenti su konstantno precenjivali učestalost inhalacije. Istraživači to tumače motivisanom distorzijom u pamćenju koja je posledica konflikta uverenja: da su lekovi opasni s jedne strane, i da su neophodni, s druge.

Izveštaji o interpersonalnim odnosima i ličnim doživljajima. U mnogim istraživanjima, od ispitanika se traži da procene kakav su odnos imali sa značajnim osobama u detinjstvu. Ispitanici u velikom procentu (on se kreće oko 90\%), svoje roditelje opisuju kao tople i prihvatajuće (Rohner, 1975; 2004). Rade to u anonimnim uslovima, bez dodatne motivacije za samopredstavljanjem. Procene kliničkih psihologa su, međutim, da je ovaj procenat svakako niži, i da je u pitanju hedonistička memorijska distorzija. U evaluaciji ovih podataka javlja se isti problem kao sa efektom nadprosečnosti: ne mogu svi ispitanici biti u pravu, ali je retroaktivno nemoguće utvrditi ko tačno izveštava a ko ne, i u kom stepenu su događaji izmenjeni. Prethodno smo spominjali studije u kojima, suočeni sa svojim starim dnevnicima, 
ispitanici ustanovljavaju da su zaboravili da su bili monarhisti, imali depresivne epizode, da su bili lečeni lekovima ili čak elektrošokovima! (Lindsay \& Read, 2006).

Pogrešni zaključci o povezanosti različitih psiholoških konstrukata. Posledice pristrasnosti u samoizveštajima pojedinaca nisu ograničene samo na netačnu evaluaciju terapije ili pogrešne zaključke o klijentima, posledice mogu biti i različiti zaključci o povezanosti psiholoških varijabli u studijama koje se oslanjaju na aktuelne podatke i studijama koje se oslanjaju na retrospektivne izveštaje pojedinaca. Tako je, na primer, snažnija povezanost između fizičkog zlostavljanja u porodici i delikventnog ponašanja utvrđena u studijama koje su koristile retrospektivni dizajn, dok je u studijama koje su koristile prospektivni dizajn ova veza slabija (Kruttschnitt \& Dornfield, 1992). U interpretaciji rezultata istraživanja treba uzeti u obzir vrstu podataka na koje se oslanja, i svakako uzeti u obzir mogućnost da je u retrospektivnim izveštajima došlo do motivisanih distorzija. 


\section{Da li pristrasnosti u samospoznaji mogu biti funkcionalne za pojedinca?}

"Životna snaga jednog čoveka meri se, pored ostalog, i njegovom sposobnošću zaboravljanja."

Ivo Andrić

Pitanje koje je za nas od posebnog značaja je upravo Šta ljudi ŽELE da saznaju o sebi? Koje će informacije verovatno prihvatiti, a koje odbaciti? Neki epistemički i pragmatički razlozi ukazuju na to da ljudi teže, ili bi barem trebalo da teže, saznanju o sebi koje je tačno, uravnoteženo i istinito. Ovo stanovište potiče još od starogrčkih filozofa: Sokrat je, na primer, tvrdio da je spremnost za suočavanje sa istinom o sebi među najvećim ljudskim vrlinama. Uočivši sklonost ljudi da nekritički prihvataju poželjne informacije o sebi, zalagao se za nepristrasnost i sistematičnost u saznavanju o sebi. Istinita samospoznaja nema samo epistemičku,već i pragmatičnu vrednost: čovek koji je svestan svojih mogućnosti i ograničenja izabraće okolinu koja mu odgovara, razviće realne ambicije, uključiće se u grupe u koje se može uklopiti, ulagaće napore u ostvarive zadatke. Ovo gledište deli i čitav niz savremenih teoretičara (Strube, Yost \& Bailey, 1992; Trope, 1986). S druge strane, moguće je da ljudi pokušavaju da održe pozitivnu sliku o sebe i štite se od informacija koje bi je ugrozile upravo iz epistemičkih razloga. Već smo ukazali na to da većina ljudi vidi sebe u pozitivnom svetlu (npr. Schwartz, 1986). Stoga pozitivan fidbek doprinosi stabilnosti i unutrašnjoj konzistentnosti slike o sebi (Swan, 1987).

Istraživanja nude dokaze za neočekivanu tezu - dobro adaptirani ljudi imaju pozitivno pristrasnu sliku o sebi, kod njih se u velikom broju sreću takozvane pozitivne iluzije. Štaviše, ove iluzije povezane su sa drugim kriterijumima adaptiranosti na socijalnu sredinu uključujući i sposobnost za brigu o drugima, sposobnost da se bude zadovoljan ili srećan, emotivnu stabilnost i radnu produktivnost (Taylor \& Brown 1988;1994; Taylor et al., 2003; Updegraff \& Taylor, 2000). Ovo viđenje postalo je poznato kao Tejlor-Braunova hipoteza, a psiholozi Šeli Tejlor i Džonatan Braun proveli su dobar deo svog istraživačkog veka braneći je i nalazeći nove dokaze koji joj idu u prilog. Tejlorova i Braun tvrde da trijada međusobno povezanih pozitivnih iluzija: (a) nerealistično pozitivna samoevaluacija, (b) precenjivanje kontrole nad događajima, i (c) nerealistični optimizam, može doprineti boljem kognitivnom, afektivnom i socijalnom funkcionisanju. Potreba za samoprecenjivanjem (self enhancement), koja stoji u osnovi ovih iluzija (za diskusiju o razgraničavanju potrebe, ponašanja i njegovih efekata vidi Sedikides \& Gregg, 2008) nije patološki fenomen - izučavanjem kliničkih subpopulacija ustanovljeno je da ne postoji kod depresivne, a postoji kod kontrolne grupe 
ispitanika. Sama činjenica da su pozitivne iluzije većinski prisutne u zdravoj populaciji ${ }^{10} \mathrm{i}$ da se uporno održavaju nije direktan dokaz njihove adaptivnosti, ali je svakako signal naučnicima da istraže razloge za to.

Pre svega, pozitivno viđenje sebe direktno doprinosi opštem osećanju dobrobiti i sreće (Taylor et al. 2003a, 2003b). Pored ove očigledne dobiti, pozitivne iluzije suptilnije deluju i na motivacionom i na kognitivnom planu: pokreću na aktivnost, obezbeđuju istrajnost i pored inicijalnih neuspeha (Armor \& Taylor, 2002); pozitivno viđenje sebe deluje na pozitivnije viđenje drugih (Ybarra, 1999), a manje opažanje rizika omogućava proaktivan pristup životu. I pozitivne iluzije o drugima mogu takođe biti adaptivne. Jedna studija o partnerskim odnosima (Murray, Holmes \& Griffin, 1996) ukazala je na činjenicu da u funkcionalnim vezama partneri idealizuju jedan drugog pa su procene partnera po nizu atributa bile pozitivnije i od samoprocena.

Postoji li, međutim, i gornja granica samoprecenjivanja, posle koje ono prestaje da bude adaptivno? Postoji priličan broj argumenata (Baumeister, 1989; McAllister et al., 2002) u prilog hipoteze o "optimalnoj margini iluzija". Prema ovoj pretpostavci, za zdravo psihološko funkcionisanje optimalna je mala do umerena pozitivna distorzija. Kod ljudi koji nemaju ovu vrstu pozitivnog otklona, realističan pogled na sebe i druge dovodi do depresivnih simptoma: u domenu ponašanja, oni oklevaju da preduzmu rizične akcije koje bi mogle da donesu uspeh; kod onih koji preteruju u optimističkom precenjivanju, slika o sebi postaje previše pozitivna (narcistički poremećaj), a procena rizika takva da se upuštaju u neostvarive poduhvate.

Čini se da su pozitivne iluzije funkcionalnije kada se tiču nekih opštijih uverenja i procena i kada ne služe kao jedina osnova za odluku o ponašanju (Armor \& Taylor, 1998). U situacijama koje imaju opštije ishode, nejasne norme ili se tiču dalje budućnosti, veća je i šansa da dođe do pozitivnih distorzija (Trope \& Liberman, 2003). Ovo možda upravo zbog toga što su ljudi na nekom nivou svesni da se njihova nerealistična očekivanja neće direktno osporiti. Pristrasnosti u pamćenju nisu direktno uvrštene u trijadu pozitivnih iluzija, ali se čini da bi je autori svrstali u prvu grupu (Sedikides \& Green, 2003; Sedikides, Green \& Pinter, 2004), jer se može pretpostaviti da precenjivanje prošlih postignuća doprinosi opažanju sebe kao kompetentnije i uspešnije osobe, odnosno nerealistično pozitivnom viđenju sebe.

\footnotetext{
${ }^{10}$ Ironično, većina ljudi smatra za sebe da je manje sklona ovakvim iluzijama, čak i kada im se direktno saopšti mehanizam njihovog delovanja ((Pronin, Gilovich, \& Ross, 2004). Ovaj bi se fenomen ubrojao u prvu klasu iluzija iz trijade.
} 
Kod ljudi koji pate od kliničke depresije i imaju izmenjenu sliku o sebi nisu utvrđene pozitivne pristrasnosti u pamćenju. Oni se, naprotiv, češće i jasnije sećaju negativnih autobiografskih događaja (Mineka \& Nugent, 1995). Depresivni pacijenti (za razliku od kontrolne grupe), sporije reaguju na pozitivne u odnosu na negativne znakove za navođenje (eng. retrieval cues) i manje su specifični u opisu pozitivnih u poređenju sa negativnim sećanjima (Williams \& Scott, 1988); potcenjuju učestalost pozitivnih, a precenjuju učestalost negativnih događaja u svojoj ličnoj istoriji (Lyubomirsky et al., 1998).

$\mathrm{S}$ druge strane, sama činjenica da je veća sklonost pristrasnostima u pamćenju pozitivno povezana sa merama na testovima ličnosti koje ukazuju na bolju adaptiranost, ne znači da je u pitanju jednosmerna kauzalna veza. Može se naime pretpostaviti i da je na delu tendencija potvrđivanja- osoba potvrđuje atribute za koje smatra da ga trenutno opisuju- bilo ponašajući se na određen način (neka vrsta samoispunjujućeg proročanstva primenjena na sopstveno ponašanje), bilo prisećajući se prošlih situacija u kojima su se određeni atributi ispoljili (Ross, 1989; Wheeler et al., 2007). Ne može se čak odbaciti ni pretpostavka da je izvor greške u oba slučaja isti, odnosno da isti mehanizmi samoprecenjivanja deluju i u samoizveštajima (na testovima ličnosti, na primer) i u zadacima prisećanja.

Zbog svega navedenog se čini da je ispravnije reći da istražujemo da li postoji opšta sklonost ka većoj pozitivnosti u viđenju sebe, sećanju na sebe i očekivanjima od sebe u budućnosti, za koju pretpostavljamo da se prenosi i na grupe kojima pripadamo. 


\section{Merenje pristrasnosti u samoevaluaciji}

U prethodnom tekstu spominjali smo da u psihološkoj literaturi postoje oprečna mišljenja $u$ vezi sa posledicama pristrasnosti u samoevaluaciji. Klinički psiholozi su tradicionalno povezivali mentalno zdravlje sa tačnim opažanjem sebe i okoline (Jahoda, 1958; Rogers, 1951). Tejlorova i Braun izneli su, međutim, drugačije gledište: samoprecenjujuće distorzije su normativne i generalno pozitivne za osobu (Taylor \& Brown, 1988, 1994).

Veliki deo ove kontroverze je, međutim, posledica razlika u kriterijumima koje istraživači koriste da bi nešto označili kao pristrasnost u samoevaluaciji (Gramzow, Eliot, Asher \& McGregor, 2002). Postoji nekoliko načina na osnovu kojih se može utvrditi da li je nečija procena sebe tačna ili pristrasna.

a. Normativni modeli. Od ispitanika se u ovoj proceduri traži da prema određenoj dimenziji uporedi sebe sa prosečnom drugom osobom. Većina ispitanika ocenjuje da su bolji od drugih, i to na čitavom nizu pozitivnih atributa. O "efektu nadprosečnosti" je već bilo reči kada smo govorili o egotizmu. Pozitivna odstupanja registrovana na ovaj način pozitivno koreliraju sa samopoštovanjem (Brown, 1986) i dominantnim pozitivnim raspoloženjem (Gibbons, 1986). Kolvin i Blok, argumentujući protiv ovakvog registrovanja samoprecenjivanja ukazuju na to da se na ovaj način ne razlikuju osobe koje istinito prepoznaju sebe kao bolje od proseka od onih koje greše u toj proceni (Colvin \& Block, 1994). Efekat nadprosečnosti ukazuje na fenomen na grupnom nivou: nemoguće je, dakle, da većina ljudi bude bolja od proseka; s druge strane, ukoliko nam je potrebna individualna mera da bismo je povezali sa drugim adaptivnim odlikama pojedinca, verovatno je da u grupu "precenjivača" svrstavamo i one koji to nisu.

Koristeći normativne modele, nemoguće je zaključiti da li su pozitivne iluzije o sebi adaptivne, zato što u grupi precenjivača postoje ljudi koji uživaju psihološke blagodeti koje su posledica povoljnih socijalnih poređenja, u kojima oni realno procenjuju sebe kao bolje od većine osoba sa kojima se porede. Drugim rečima, bez eksternog kriterijuma nemoguće je oceniti istinitost nečijeg samoopisa.

b. Socijalni konsenzus. U potrazi za eksternim kriterijumom koji bi ukazao na samoprecenjivanje, istraživači su brzo stigli do socijalnog konsenzusa: samoprecenjivanje se može definisati kao nepodudaranje između načina na koji vidimo sebe i načina na koji nas vide drugi. U jednom je istraživanju (Colvin, Block \& Funder, 1995) poređena samoprocena ispitanika na 100 ličnosnih atributa sa rejtinzima posmatrača na istim atributima. U ulozi 
posmatrača bili su psiholozi i studenti psihologije koji su bili u interakciji sa ispitanicima "u velikom broju situacija tokom nekoliko dana". Grupa koja je sebe procenjivala bolje nego što su ih procenjivali drugi nazvana je "precenjivačima". Nakon 5 godina, posmatrači su ponovo procenjivali sve učesnike $u$ istraživanju. Grupa precenjivača procenjena je negativnije od druge grupe. U sličnoj studiji (Paulhus, 1998), poređene su samoprocene studenata sa procenama njihovih bliskih prijatelja. Kao precenjivači označeni su oni koji su sebe pozitivnije ocenjivali nego što su ih ocenjivali prijatelji. Svi procenjeni studenti su u narednih osam nedelja učestvovali u seriji grupnih diskusija sa kolegama koji ih nisu poznavali od ranije. "Precenjivači" su nakon prvih diskusija bili pozitivno procenjeni od strane nepoznatih kolega, ali je njihov rejting bivao sve lošiji što je vreme prolazilo. Čini se da su ovako definisani "precenjivači" uspevali da ostave dobar prvi utisak, ali da je taj utisak bledeo vremenom.

U ovakvoj paradigmi, pristrasnosti u samoevaluaciji mere se preko podudaranja sa procenama treće strane, a njihova adaptivnost procenjuje na osnovu utisaka drugih. Upravo se ovde krije izvesna cirkularnost: moguće je da povezanost samoprecenjivanja i loše psihološke prilagođenosti posledica činjenice da su obe grupe posmatrača formirale slične sudove o pojedinim učesnicima. Pored toga, činjenica da su "precenjivači" manje uspešni u socijalnim interakcijama, ne znači da nisu efikasniji u izvođenju određenih aktivnosti i da se ne osećaju bolje od drugih. Paulus je u zaključku svojih ogleda ustvrdio da je sklonost ka samoprecenjivanju "mešani blagoslov": pozitivno povezan sa samopoštovanjem i rezilijentnošću, a negativno sa evaluacijama drugih (Paulhus, 1988).

Na kraju, u oba ova pristupa, istraživači su koristili atribute koji su opšti i nedovoljno precizno definisani (na primer "inteligentan/na", "dobro prilagođen/a", "nadaren/a"). Na taj način ispitanicima je dozvoljeno da u atribute učitaju idiosinkratična značenja, i da ih definišu onako kako im odgovara, što kasnije čini njihove procene teško uporedivim. Na primer, jedna osoba može tvrditi za sebe da je talentovana zbog nadprosečnih muzičkih sposobnosti, a druga zbog akademskog uspeha (Dunning, Heath \& Suls, 2004). Interpersonalno slaganje u vezi sa opštom pozitivnošću odnosno negativnošću atributa takođe je upitno: osobine kao što su "dominantan" ili "ponosan" mogu se proceniti kao pozitivne ili negativne, zavisno od konteksta.

Operacionalni kriterijum. Da bi se izbegli ovi problemi u definisanju, istraživači predlažu da se procenjuju atributi koji su specifični, objektivni i proverljivi (Robins \& John, 1997).

To mogu biti rezultati na testovima sposobnosti, na prijemnim ispitima, prosečne ocene, pozicije na rang-listama. Razlika između saopštenog i pravog postignuća predstavlja meru 
precenjivanja koja je izdvaja prave precenjivače (kod kojih postoji stvarna razlika) od uspešnih (oni koji sebe vide pozitivno zahvaljujući pravom pozitivnom fidbeku). Pored toga, ne postoji opasnost od različitog tumačenja atributa, s obzirom da je reč o konkretnom postignuću a ne opštoj sposobnosti.

Ukoliko prihvatimo operacionalni kriterijum, otvara se novo metodološko pitanje: kako izračunati pristrasnost u samoevaluaciji? Moguće je jednostavno od mere samoizveštaja oduzeti kriterijumsku procenu i razliku tretirati kao meru pristrasnosti. U odeljku o pristrasnostima je već bilo reči o razlozima zbog kojih ovaj pristup nije uvek preporučljiv (Cronbach \& Furby, 1970). Apsolutni iznos postignuća limitira moguć opseg greške u samoproceni (ukoliko neko, na primer, ima skor 90 na skali gde je 100 maksimum, ima na raspolaganju dodatnih 10 bodova koje može sebi pripisati, dok je onome ko ima niži skor na raspolaganju veći broj potencijalnih bodova). Jedan od načina na koji se može prevazići ovaj problem je korišćenje reziduala umesto apsolutne razlike (Paulhus \& John, 1998). Ako se mera samoizveštaja uzme kao prediktor, a operacionalni kriterijum kao kriterijumska varijabla, reziduali ove predikcije tretiraju se kao indeksi pristrasnosti. Neki autori, međutim tvrde da se ovom merom statističke kontrole zapravo brišu individualne razlike koje su psihološki relevantne i koje realnije opisuju polaznu situaciju pojedinca (Colvin, Block \& Funder, 1996) . 


\section{Greška preterivanja}

Ova greška odnosi se na sklonost ljudi da precenjuju sopstvena postignuća, odnosno da izveštavaju o višim postignućima na testovima iz različitih domena nego što je to zaista slučaj. Nekoliko je razloga za detaljnije eksperimentalno proučavanje ove pojave. Pre svega, pošto je u pitanju izveštavanje o sopstvenom postignuću, spada istovremeno i $\mathrm{u}$ autobiografsku memoriju, a i u samoevaluaciju, tako da otvara mogućnosti da se fenomen sagleda iz više perspektiva. Pored toga, s obzirom da je u pitanju motivisana distorzija, zanimljivo je koji motivi je zapravo facilitiraju, a koji inhibiraju. Pošto je kriterijum greške lako operacionalizovati (predstavlja razliku između skora koji je saopšten ispitanicima i skora o kome oni naknadno izveštavaju, statistički korigovanu za visinu skora), rešava se složen problem operacionalizacije tačnosti prisećanja, i kvantifikacije stepena tačnosti izveštaja.

Greška preterivanja prvo je ustanovljena u domenu akademskih postignuća, gde su ispitanici imali tendenciju da izveštavaju o višoj prosečnoj oceni tokom studija (Gramzow, Elliot, Asher \& Mc Gregor, 2002) ili o većem broju visokih ocena (Bahrick et al., 1993; Bahrick et al., 2008), a zatim i u izveštavanju o rezultatima različitih testova sposobnosti i ličnosti (Willard \& Gramzow, 2007). U tipičnom eksperimentu u kome se meri greška preterivanja, od ispitanika se traži da izveste o nekom svom prošlom postignuću u kvantitativnoj formi (izraženom preko broja poena, prosečne ocene, percentilnog ranga i slično). Pri tom, istraživači imaju istinit podatak o individualnim postignućima ispitanika (bilo registrovan $\mathrm{u}$ nekoj bazi podataka, bilo kao informaciju koja je deo eksperimentalne manipulacije), tako da je moguće kvantifikovati odstupanje. U nekim ogledima ispitanicima se saopštava njihovo stvarno postignuće (Gramzow \& Wilard, 2006), a $\mathrm{u}$ drugim se fidbek o postignuću uniformiše (Willard \& Gramzow, 2008). U prvom slučaju, ogled je ekološki validniji, s obzirom da povratna informacija o uspehu deluje uverljivo; u drugom slučaju može se kontrolisati uspešnost ispitanika i eventualna margina greške. Obično se kao zavisna varijabla uzima intenzitet greške preterivanja (razlika stvarnog skora i onog koji ispitanik saopštava), mada se često saopštava i proporcija onih koji tačno izveštavaju, precenjuju ili potcenjuju svoja postignuća. Većina ispitanika najčešće spada u grupu precenjivača, a uobičajen obim odstupanja je 5\% do 10\% inicijalnog skora (Bahrick et al., 2008; Gramzow et al., 2002; Willard \& Gramzow, 2008).

Istraživači ovog fenomena pažljivo su razgraničili efekat preterivanja od eventualnog zaboravljanja: dok grupa ispitanika motivisana da se tačno seti svojih skorova to i uspeva da 
učini, u kontrolnoj se registruje uobičajeno pozitivno odstupanje. Pored toga, ako ispitanici veruju da se njihovi iskazi neće proveravati, pokazuju snažniju tendenciju preterivanja (Gramzow \& Wilard, 2006; Willard \& Gramzow, 2008, 2009). O tome kako bi se ovaj naizgled paradoks ("da bi se netačno setili, moramo se prethodno tačno setiti") može rešiti, bilo je reči u odeljku koji se bavio procesima motivisanog zaboravljanja.

$\mathrm{S}$ druge strane, postoje nalazi koji govore da nije u pitanju jednostavno obmanjivanje (pri kome su ispitanici sasvim svesni da netačno izveštavaju): fenomen je izraženiji ako je moguće pogrešku pripisati nekim spoljnim faktorima (protoku vremena, zadatku distraktoru i slično), a javlja se i u situaciji kada su skorovi anonimni i dostupni jedino samom ispitaniku (Willard \& Gramzow, 2009).

Ova tendencija korelira sa izvesnim dispozicionim karakteristikama koje ukazuju na snažniji motiv samoosnaživanja - izraženijim samomotrenjem i jačom tendencijom ka davanju socijalno poželjnih odgovora (Willard \& Gramzow, 2006). Pored toga, veću sklonost ka grešci preterivanja ispoljavaju akademski uspešniji pojedinci, sa snažnijim motivom postignuća i višim samopoštovanjem (Willard \& Gramzow, 2006). 


\section{Problem istraživanja}

Istraživanje koje smo osmislili imalo je za cilj da odgovori na nekoliko međusobno uslovljenih pitanja: (a) da li su ljudi skloni grešci preterivanja, odnosno da li preuveličavaju svoja prošla postignuća u različitim domenima; (b) koji faktori doprinose ovoj grešci, i (c) ima li individualnih razlika u sklonosti ka grešci preterivanja i da li su pojedinci koji su joj skloniji, istovremeno i bolje psihološki adaptirani pojedinci.

Ukoliko je tačna pretpostavka da je u osnovi ove memorijske distorzije potreba za zaštitom ili pojačavanjem pozitivne slike o sebi, greška preterivanja trebalo bi da bude izraženija u situacijama koje su u većoj meri ego-involvirajuće (Greenwald, 1980; Hyman \& Loftus, 1998). Znajući da lični uspesi i neuspesi imaju specijalan status u pamćenju, moglo bi se postaviti i pitanje da li bi ovaj efekat bio izraženiji u slučaju ličnog uspeha ili neuspeha. Smisleno bi bilo pretpostaviti da će uspesi biti prenaglašeni, ali i da će neuspesi biti ublaženi: prva strategija bi se mogla nazvati samoafirmišućom, a druga samozaštitnom.

Pored toga, ukoliko eksperiment dizajniramo tako da isključuje motiv samoprecenjivanja kao uzrok sistematskog iskrivljavanja $\mathrm{i}$ onda proverimo da li će se registrovati greška preterivanja, potvrdan odgovor ukazivao bi na to da postoji isključivo kognitivni mehanizam koji pravi selekciju po pozitivnosti, koji deluje i nezavisno od ličnih motiva (Boucher \& Osgood, 1969).

Takođe, ukoliko je tačno da je veća šansa da se pristrasnosti ispolje ukoliko su informacije nejasnije, dvosmislenije i manje distinktivne u sećanju ispitanika, greška preterivanja trebalo bi da se pojačava sa vremenom (Bahrick et al., 2008; Gramzow \& Willard, 2006; Willard \& Gramzow, 2008).

Polazeći od činjenice da su grupe kojima pripadamo važne za sliku o sebi, možemo pretpostaviti i da se isti procesi pristrasnog pamćenja koriste za pamćenje informacija o sopstvenim nasuprot tuđim grupama (Ybarra, Stephan \& Schaberg, 2000),

Na kraju, ako očekujemo da postoji opšta tendencija ka pozitivnosti u viđenju sebe i grupa kojima pripadamo, pristrasno pamćenje bi trebalo da bude pozitivno povezano sa nekim indikatorima dobre psihološke adaptiranosti. Drugim rečima, očekivalo bi se da pojedinci koji su skloni određenom tipu grešaka u pamćenju budu i (a) pozitivnijeg opšteg raspoloženja, (b) višeg samopoštovanja, (c) optimističniji u odnosu na budućnost i (d) izraženijeg motiva postignuća (ako su u pitanju studenti, akademskog postignuća). 
Ukoliko bi se očekivanja potvrdila, to bi pre svega bio još jedan doprinos korpusu empirijskih nalaza o različitim greškama kojima su ljudi skloni prilikom opažanja i pamćenja socijalnog sveta. Pored toga, povezanost fenomena u laboratorijskim i prirodnim uslovima, ukazala bi na postojanje izvesne strategije (pri čemu, naravno, ne smatramo da je u pitanju svestan i unapred osmišljen plan) pamćenja informacija. Praktične implikacije nalaza bile bi višestruke: pre svega predstavljale bi jasan signal da događaje u izveštajima pojedinca iz prošlosti ne bi trebalo tretirati kao činjenice, već kao uverenja o činjenicama (važno imati na umu prilikom intervjuisanja ili u psihoterapijskom radu (vidi Hyman \& Loftus, 1998), a što su podaci za kojima tragamo značajniji za samoevaluaciju osobe, veće su šanse da budu pristrasno zapamćeni. Nalazi bi takođe ukazivali na to na koji je način moguće motivisati pojedinca da iskreno izveštava, a koje situacije ga ohrabruju da pravi ovu vrstu grešaka. Dalje, ako bi se i hipoteza o pozitivnoj povezanosti ovakvih grešaka i nekih indikatora adaptiranosti pokazala tačnom, to bi ukazivalo na potrebu da se revidira intuitivno uverenje o tome da je tačno samoopažanje i pamćenje podataka o sebi i drugima odlika dobro prilagođenih i stabilnih pojedinaca. Bio bi to još jedan nalaz u prilog ideji da su greške u socijalnoj kogniciji ne samo neizbežne, već i potrebne - kako zbog toga što u većini slučajeva štede kognitivnu energiju (ukoliko se događaji uklapaju u opštu pozitivnu sliku o sebi, nema potrebe da je revidiramo, menjamo), tako i zbog toga što često predstavljaju deo šire strategije ego zaštite (omogućavaju nam da se dobro osećamo i imamo aktivan pristup životu). 


\section{Ciljevi istraživanja}

Istraživanje ima nekoliko osnovnih ciljeva:

1. Proveriti da li je moguće replicirati dokumentovan fenomen greške preterivanja $u$ prirodnom i laboratorijskom okruženju;

2. Utvrditi da li je ovaj fenomen izraženiji u situacijama koje su više ego-involvirajuće, odnosno u slučaju uspeha ili neuspeha, da li je izraženiji u slučaju pamćenja informacija o sebi ili drugima, kao i da li važi i za pamćenje informacija o grupi kojoj pripadamo nasuprot grupi kojoj ne pripadamo.

3. Utvrditi da li postoji razlika u izraženosti fenomena u zavisnosti od dostupnosti sadržaja memorije, operacionalizovane preko vremenske udaljenosti događaja od momenta ispitivanja;

4. Utvrditi da li je ovaj tip greške pamćenja pozitivno povezan sa nekim indikatorima dobre adaptiranosti, odnosno sa "psihološkim resursima", kako ih naziva Tejlorova (Taylor et al., 2003). 


\section{Hipoteze}

Oslanjajući se na prethodno navedene empirijske i teorijske argumente, postavili smo sledeće hipoteze:

1. Javiće se precenjivanje sopstvenih postignuća prilikom saopštavanja skorova na prijemnom ispitu, kao i laboratorijskim testovima; javiće se u slučaju informacija o pojedincu ali i u slučaju informacija o grupi kojoj pojedinac pripada.

2. Greška preterivanja biće izraženija u slučaju:

a. veće uključenosti ispitanika (izbor predmeta "merenja" biće rezultat pretestiranja- meriće se osobine koje su u proseku značajne, odnosno manje značajne za sliku o sebi- npr. opšta inteligencija naspram sposobnosti rešavanja anagrama), za sebe u poređenju sa drugima (Greenwald, 1981);

b. postoje argumenti i za pretpostavku da će biti izraženija u situaciji uspeha u poredjenju sa neuspehom (Louie, 1999; Willard \& Gramzow, 2009), ali i suprotni argumenti, na osnovu kojih bi se mogla formulisati konkurentska hipoteza, da će biti izraženija u situaciji neuspeha u poređenju sa uspehom (Sedikides \& Green 2000; 2004);

c. u situacijama koje provociraju motiv za samoprikazivanjem (javno naspram privatnog saopštavanja rezultata);

d. i kada je realni dogadjaj manje dostupan u memoriji (vremenski udaljeniji od momenta ispitivanja) (Willard \& Gramzow, 2008; Bahrick, Hall \& Dunloski, 1993; Bahrick, Hall \& da Costa, 2008).

3. Sklonost ka grešci preterivanja biće pozitivno povezana sa indikatorima dobre adaptiranosti (psihološkim resursima):

a. Dominantnim pozitivnim afektom (Willard \& Gramzow, 2008),

b. Samopoštovanjem (Baumeister et al., 2003),

c. Generalnim životnim optimizmom (Chang \& Sanna, 2003),

d. Akademskim ambicijama kao predstavnikom motiva za postignućem. 


\section{Metodologija}

Da bi se utvrdila sklonost grešci preterivanja u različitim domenima, utvrdili faktori koji na nju utiču i eventualne individualne razlike, istraživanje je osmišljeno kao serija od šest međusobno povezanih ogleda. Ispitanici su izveštavali o svojim prošlim postignućima: o uspehu u srednjoj školi ili na prijemnom ispitu za fakultet (Eksperiment 1), o percentilnom rangu koji im je saopšten nakon što su elektronski popunjavali testove različitog sadržaja (Eksperiment 2 i 3), o ukupnom procentu uspešno rešenih zadataka nakon što su dobijali informaciju o tačnosti nakon svakog pojedinačnog zadatka (Eksperiment 4.1 i 4.2), o atributima i postignućima svoje i tuđe etničke grupe nakon čitanja novinskog članka (Eksperiment 5). Radi bolje preglednosti, prvo ćemo prikazati zajednički metodološki koncept svih ogleda, a zatim metodologiju svakog pojedinačnog ogleda, rezultate i diskusiju rezultata tog ogleda. Na kraju ćemo pokušati da dobijene rezultate objedinimo i zajednički diskutujemo njihove implikacije.

\section{Procedura i učesnici}

Istraživanje smo osmislili i sproveli u nekoliko stadijuma. Prvo je bilo potrebno razviti instrumente koji su zajednički za sve oglede. To je podrazumevalo:

1. Pripremu baterije testova koja meri psihološku adaptiranost. Izrada i preliminarno testiranje Skale dominantnog raspoloženja i Skale akademskih ambicija, prevod i prilagođavanje drugih instrumenata.

2. Pripremu testova za merenje postignuća u različitim domenima.

3. Pripremu instrumenta za registrovanje prethodno saopštenih postignuća.

Svaki eksperiment imao je svoju specifičnu proceduru.

Eksperiment 1: studenti prve ili treće godine su saopštavali informaciju o broju bodova i rangu na prijemnom, i uz različite instrukcije za eksperimentalne grupe, a ta se informacija poredila sa pravim postignućem sačuvanim u fakultetskoj bazi podataka. 
Eksperiment 2 sproveli smo u nekoliko faza:

a. Elektronsko popunjavanje testa (visoko ili nisko involvirajućeg sadržaja)

b. Saopštavanje netačnih informacija o rezultatu u formi percentilnog ranga (četiri skora koja su slučajnim izborom dodeljena subjektima)

c. Pauza od 7 do 10 dana samo za jednu grupu

d. Registrovanje odgovora ispitanika na pitanje o postignućima (skorovima) na testu .

Eksperiment 3 takođe je sproveden u nekoliko faza:

a. Elektronsko popunjavanje testa

b. Saopštavanje netačnih informacija o rezultatu u formi percentilnog ranga (uspeh ili neuspeh)

c. Pauza od 7 do 10 dana samo za jednu grupu

d. Registrovanje odgovora ispitanika na pitanje o postignućima (skorovima) na testu .

Eksperiment 4.1 podrazumevao je

a. Elektronsko popunjavanje testa, odnosno posmatranje laboratorijskog partnera uz fidbek o tačnosti nakon svakog pojedinačnog zadatka.

b. Procena uspešnosti (procenta tačno rešenih zadataka) na oba subtesta od strane aktera i posmatrača.

Eksperiment 4.2

a. Rešavanje testa opšte kulture, odnosno čitanje testa koji je rešen od strane nekog drugog,

b. Ocenjivanje testa pomoću ključa, bez sumiranja skora,

c. Procena broja tačno rešenih zadataka i prisećanje sadržaja zadataka od strane aktera i posmatrača.

Eksperiment 5

a. Procena poželjnosti određenih personalnih karakteristika (ili ponašanja)

b. Izbor najčešće navođenih poželjnih i nepoželjnih personalnih karakteristika (ili ponašanja), formiranje grupe poželjnih i nepoželjnih

c. Pripisivanje niza jednako poželjnih (nepoželjnih) atributa sopstvenoj i tuđoj grupi, na osnovu čega su kreirana po 2 uravnotežena profila (postojale su dve verzije stimulus materijala dobijene kontrabalansiranjem, u polovini slučajeva grupi A pripisane su verzije P1 (lista poželjnih atributa 1) i N1 (lista nepoželjnih atributa 1), a u drugoj polovini, grupi A su pripisane verzije P2 i N2; suprotno važi za grupu B). Redosled prikazivanja profila takođe je bio balansiran (jedna grupa prvo čita profil za grupu A pa za grupu B, druga obrnuto). 
d. Zadatak memorisanja, koji je uključivao: (a) slobodno prisećanje atributa za obe grupe (b) reprodukciju skorova na bateriji testova sposobnosti za obe grupe, na osnovu čega bi se računala greška u reprodukovanim skorovima za obe grupe (na svakoj skali iz baterije i ukupno).

Istraživanje se sprovodilo u grupama od pet do osam ispitanika. Testirani su elektronski, na prenosivim računarima, u za to određenoj prostoriji na fakultetu (školi). Lažni fidbek o rezultatima dat je elektronski, a dodatna uputstva usmeno, od strane ispitivača. Ispitivači su bili studenti psihologije koji nisu bili upoznati sa ciljevima i hipotezama u eksperimentima. Učešće je bilo dobrovoljno, a u nekim slučajevima su ispitanici zauzvrat dobijali bodove iz predispitnih aktivnosti. Svima je jasno predočen razlog istraživanja i rečeno im je da je moguće u svakom trenutku odustati od daljeg učešća. Ispitanicima je data mogućnost da se umesto imena, evidencija o njima vodi preko broja indeksa ili preko šifre koju su sami smišljali (zbog "uparivanja" podataka sa testa i retesta). Na kraju svakog ogleda istraživači su ispitanicima objasnili svrhu istraživanja, ili je to učinio školski psiholog prema pismenom uputstvu od strane istraživača.

Uzorak su činili studenti prve i četvrte godine na odeljenju za sociologiju Filozofskog fakulteta, druge i treće godine na odeljenju za psihologiju Filozofskog fakulteta, treće godine na odeljenju za psihologiju Fakulteta za medije i komunikaciju, prve i druge godine Fakulteta za specijalnu edukaciju i rehabilitiaciju i treće godine Fakulteta organizacionih nauka u Beogradu. Ispitanici su slučajnim izborom bili svrstani u jednu od eksperimentalnih grupa (u drugom ogledu, u grupu visoko ili nisko involviranih, i u grupu koja javno ili privatno saopštava rezultate; u trećem ogledu, u grupu uspešnih ili neuspešnih, i u grupu koja javno ili privatno saopštava rezultate odnosno saopštava ih neposredno ili odloženo). Minimalan broj subjekata po eksperimentalnoj grupi bio je 20. Raspored ispitanika po ogledima dat je u Tabeli 1, a po eksperimentalnim grupama za prva tri ogleda ${ }^{11}$ u Tabelama 4.1, 4.2 i 4.3 u Prilogu 4.

\footnotetext{
${ }^{11}$ Termini ogled i eksperiment u tekstu su tretirani kao sinonimi i ravnopravno korišćeni.
} 
Tabela 1

Broj učesnika po eksperimentima

\begin{tabular}{lc}
\hline \multicolumn{1}{c}{ Naziv ogleda } & Broj \\
& ispitanika \\
\hline Eksp. 1 Pamćenje školskog uspeha i postignuća na prijemnom ispitu & 105 \\
Eksp. 2 Pamćenje rezultata na testu vizuelne percepcije ili inteligencije & 137 \\
Eksp. 3 Pamćenje rezultata na testu socijalno-kognitivnih sposobnosti & 167 \\
Eksp. 4.1 Akter-posmatrač, test vizuelne percepcije & 40 \\
Eksp. 4.2 Akter-posmatrač, test opšte kulture & 46 \\
Eksp. 5 Pamćenje postignuća sopstvene i tuđe grupe & 63 \\
Ukupno ispitanika & 558 \\
\hline
\end{tabular}

Iako bi nacrt ponovljen po ispitanicima omogućio koreliranje nekoliko individualnih mera preterivanja, odnosno grešaka u pamćenju, opredelili smo se neponovljen nacrt, pre svega zbog očuvanja verodostojnosti eksperimentalne manipulacije. Verujemo da bi izlaganje jedne osobe sličnoj situaciji tri puta, makar i pod različitim izgovorima ( $A$ sada pokušajte da se prisetite svog rezultata ili rezultata laboratorijskog partnera) povećalo verovatnoću da će naslutiti cilj ogleda. Pored toga, različiti subjekti obezbedili su nam veći uzorak a time i veću pouzdanost zaključaka.

\section{Korišćeni instrumenti}

Za merenje opšteg odnosa prema sebi, očekivanja od budućnosti i dominantnog afekta, koristili smo nekoliko instrumenata:

1. Skala dominantnog raspoloženja koja se sastoji iz 10 sedmostepenih skala bipolarnih atributa kojima se opisuje raspoloženje ispitanika (srećno/nesrećno; zaštićeno/nezaštićeno, moćno/nemoćno itd.). S obzirom da je utvrđena zadovoljavajuća unutrašnja pouzdanost instrumenta (Tabela 3), kreiran je i indeks ukupne pozitivnosti kao zbir odgovora na svim atributima, koji je mogao uzeti vrednosti od 10 do 70; veće vrednosti ukazivale su na pozitivnije dominantno raspoloženje.

2. Za merenje samopoštovanja korišćena je Rozenbergova skala (Rozenberg, 1966) kao najbolje validiran i empirijski načešće proveravan istrument. Sastoji se od 10 tvrdnji Likertovog tipa koji opisuju ispitanikov odnos prema sebi i svojim sposobnostima 
(npr. "Mislim da vredim barem koliko i drugi ljudi" ili "Osećam da posedujem niz vrednih osobina"). Ukupan skor varira od 10-100, pri čemu viši skorovi uukazuju na veće samopoštovanje. Skala je u našem, kao i mnogim drugim istraživanjima, pokazala zadovoljavajuću pouzdanost (Tabela 3).

3. Revidirana skala opšte životne orijentacije (Life orientation scale, LOT, Scheier et al., 1994). U pitanju je skala sa šest tvrdnji (plus četiri takozvane "filer" tvrdnje) koja meri individualne razlike u optimizmu (npr. "U nesigurna vremena, obično očekujem najbolje") odnosno pesimizmu (npr. "Ako postoji mogućnost da mi se nešto loše desi, sigurno će se i desiti."). Ispitanici ocenjuju u kojoj meri se slažu sa datim tvrdnjama na četvorostepenoj skali Likertovog tipa. LOT-R je kratka modifikovana verzija originalne LOT skale (LOT;Scheier \& Carver, 1985) za koju je utvrđeno da korelira sa prvobitnom skalom .95 i koja je kros kulturalno validirana (Chang, Sanna \& Yang, 2003). Ovakva skraćena verzija je u našem istraživanju pokazala dobre metrijske karakteristike (Tabela 3)

4. Skala akademskih ambicija, konstruisana je za potrebe istraživanja da bi se utvrdile individualne razlike u želji za uspehom na studijama (u srednjoj školi) i sastojala se od četiri tvrdnje tipa "Dajem sve od sebe da budem dobar učenik/student", pri čemu je jedna tvrdnja bila inverzno formulisana. Ispitanici ocenjuju slaganje sa svakom od tvrdnji na petostepenoj skali Likertovog tipa. Ukupan skor može da varira od 4 do 20; veći skorovi ukazuju na više akademske ambicije. Ova skala pokazala se kao najmanje pouzdana (Tabela 3). S obzirom na mali broj tvrdnji koji je sačinjavaju i činjenicu da je pouzdanost na granici prihvatljive za skale stavova, odlučili smo da je, uz izvesne rezerve, ipak uključimo u dalje analize.

5. Spontano evocirana autobiografska sećanja. Zadatak ispitanika bio je da bez slekcije navede pet sećanja iz ličnog života. Kako ispitanici ne bi usvojili određenu strategiju pretraživanja sećanja (na primer, pretraživanje u skladu sa opaženim očekivanjem istraživača) dobili su neutralnu instrukciju da opišu događaje koji im prvi padnu napamet (Conway \& Holmes, 2004; Mihić, Krstić \& Ignjatović, 2009). Naglašeno im je i da ne treba da navode sećanja na značajne, formativne događaje, već one kojih se prvih sete i da treba da ih opišu ukratko, u nekoliko reči. Nakon toga, ispitanici su dobijali uputstvo da uz svaki događaj upišu +, - ili 0 u zavisnosti od toga da li ga pamte kao pozitivan (uz njega vezuju lepa osećanja), neutralan ili negativan (uz njega vezuju loša, neprijatna osećanja). Na osnovu njihovih odgovora kreiran je i indeks pozitivnosti autobiografskih sećanja, kao odnos broja događaja sa pozitivnim 
afektivnim tonom i ukupnog broja evociranih događaja. Slična tehnika merenja korišćena je u mnogim istraživanjima autobiografske memorije (Waldfogel 1948; Suedfeld \& Euch, 1995; Walker, Skowronski \& Thompson, 2003).

Skorovi na svim skalama bili su normalno distribuirani (Tabela 2), a pošto svaki od instrumenata ima ambiciju da bude relativno homogen, odnosno da meri jedinstven fenomen, izračunali smo pouzdanost i ispitali faktorsku strukturu svakog instrumenta pojedinačno. Faktorska analiza utvrdila je da je prvim faktorom objašnjeno između 37\% i 50\% varijanse $(\text { Tabela } 3)^{12}$

Tabela 2

Testiranje normalnosti distribucija dispozicionih mera

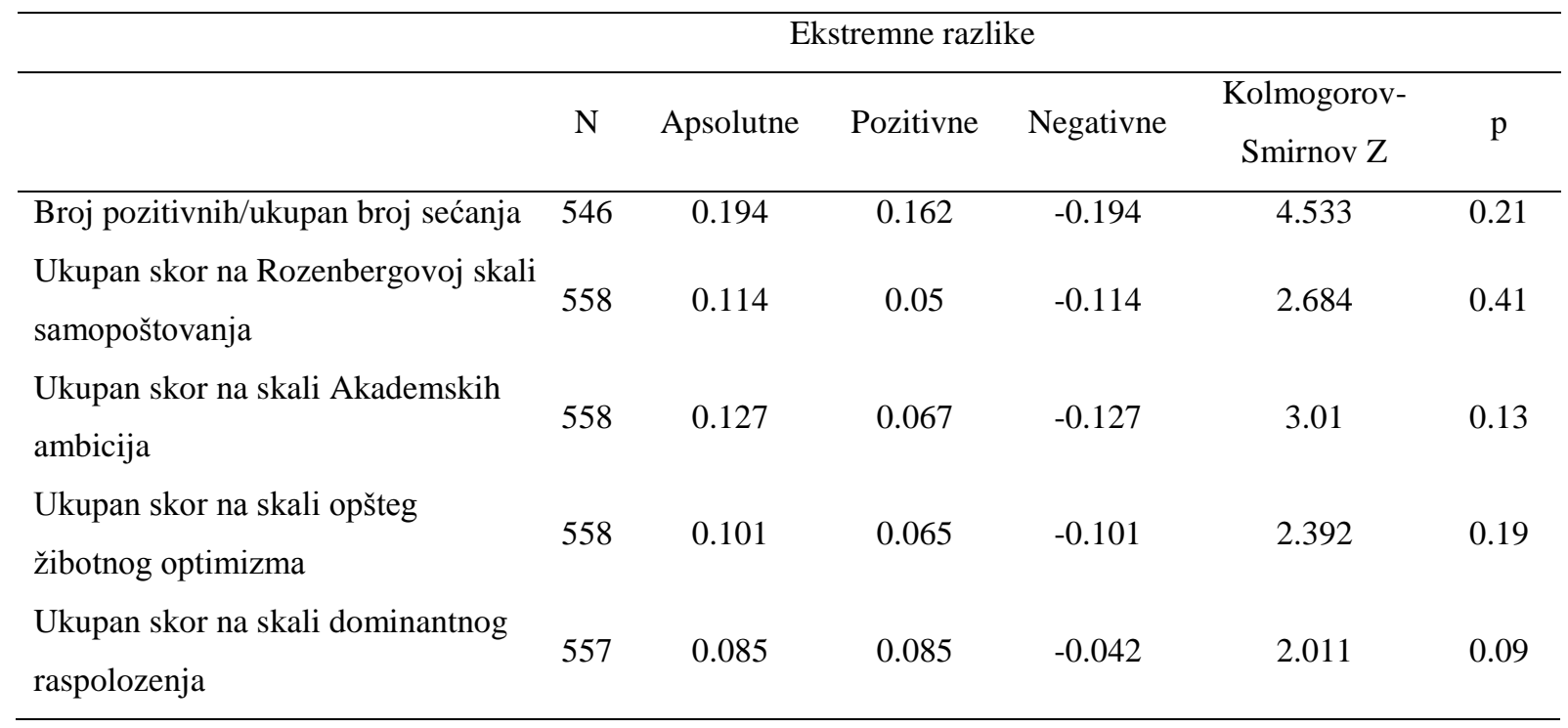

\footnotetext{
${ }^{12}$ Detaljni rezultati faktorske analize za sve instrumente nalaze se u Prilogu 4
} 
Tabela 3

Metrijske karakteristike skala

\begin{tabular}{|c|c|c|c|c|c|}
\hline & $\begin{array}{c}\text { Broj } \\
\text { tvrdnji }\end{array}$ & $\begin{array}{l}\text { Pouzdanost } \\
(\dot{\alpha})\end{array}$ & $\begin{array}{l}\text { Broj ekstrahovanih } \\
\text { faktora } \\
\text { (eksploratorna FA) }\end{array}$ & $\begin{array}{l}\text { Procenat } \\
\text { varijanse } \\
\text { objašnjen } \\
\text { prvim } \\
\text { faktorom }\end{array}$ & $\begin{array}{c}\text { Procenat } \\
\text { varijanse } \\
\text { objašnjen } \\
\text { drugim } \\
\text { faktorom }\end{array}$ \\
\hline Skala dominantnog raspoloženja & 10 & .884 & 2 & 50.1 & 10.8 \\
\hline Skala samopoštovanja & 10 & .802 & 2 & 37.1 & 13 \\
\hline Skala akademskih ambicija & 4 & .563 & 1 & 44 & -- \\
\hline Skala životnog optimizma (LOT) & 6 & .750 & 2 & 41.9 & 19 \\
\hline
\end{tabular}

Greška preterivanja operacionalizovana je na više načina. Pre svega, utvrđene su frekvencije precenjivača, tačnih izveštača i potcenjivača kako bi se stekla slika o zastupljenosti različitih strategija. Zatim je proveravano da li se registrovana greška preterivanja značajno razlikuje od nule, odnosno da li skorovi o kojima ispitanici izveštavaju statistički značajno odstupaju od skorova koji su im saopšteni. Nakon toga su rađene analize sa intenzitetom greške preterivanja kao zavisnom varijablom. Ova dva pokazatelja (frekvencija onih koji prave grešku i raspon greške) ne moraju nužno da daju saglasne rezultate: moguće je, na primer, da postoji mali broj precenjivača sa velikim rasponom greške ili da je raspon greške veći kod podcenjivača nego kod precenjivača i slično. Uopšte uzev, o sistemskoj grešci imali bismo prava da govorimo ukoliko utvrdimo da većina ljudi greši u istom smeru, ali ne i ako utvrdimo da mali broj ljudi pravi grešku velikog opsega. Pored toga, da bismo govorili o motivisanom pamćenju, moramo proveriti da li sa protokom vremena dolazi do sve većeg odstupanja u izveštavanju u oba smera (precenjivanje i potcenjivanje) ili se javlja asimetrija (sve veće precenjivanje). Zbog toga smo računali i apsolutno odstupanje od saopštenih skorova i to tretirali kao zavisnu varijablu. $\mathrm{Na}$ kraju, da bi se eliminisao "efekat plafona" u eksperimentima u kojima je bilo potrebno, rađene su analize sa rezidualima kao zavisnom varijablom. 


\section{Prikaz studije}

\section{Eksperiment 1}

\section{Dizajn}

U prvom ogledu proveravalo se postojanje greške preterivanja u prirodnim uslovima. Cilj ovog ogleda bio je da se utvrdi da li studenti preuveličavaju (a) srednjoškolski uspeh i (b) broj bodova sa prijemnog ispita i prilikom upisa na fakultet. Podatke o broju bodova i srednjoškolskom uspehu administracija fakulteta arhivira u elektronskoj formi za svakog studenta, što je omogućilo povezivanje realnih i memorisanih skorova ${ }^{13}$. Dizajn ogleda bio je 2 (memorijska dostupnost informacija, sa dva nivoa: visoka i niska) x 2 (motivisanost za prisećanje, sa dva nivoa: motivacija za tačnošću, bez motivacione intervencije ${ }^{14}$ ). Godina studija služila je kao mera dostupnosti informacija.

\section{Procedura i učesnici}

U ogledu je uzelo učešće 105 studenata prve i treće godine Filozofskog fakulteta, odseka za sociologiju. Objašnjeno im je da je ogled deo istraživanja u okviru doktorske teze i garantovana im je anonimnost. Od njih je zatraženo da popune upitnik koji se sastojao iz skala za merenje adaptiranosti, testa spontanog autobiografskog pamćenja i bloka u kome se od njih traži da navedu prosečne ocene u četiri razreda srednje škole i ukupan broj poena na prijemnom ispitu za fakultet. Studenti su slučajnim izborom svrstani u jednu od tri eksperimentalne grupe (raspored ispitanika po eksperimentalnim grupama u Tabeli $4.1 \mathrm{u}$ Prilogu 4) koje su dobile različitu instrukciju: jedna grupa dobila je instrukciju čiji je cilj bio da provocira motivaciju za tačnošću:

\footnotetext{
${ }^{13}$ Autorka se zahvaljuje upravi Filozofskog fakulteta u Beogradu na pristupu ovim podacima.

${ }^{14}$ Prvobitnim nacrtom bila je predviđena i treća grupa koja bi javno saopštavala svoje rezultate. Od te ideje se odustalo nakon nekoliko usmenih intervjua u kojima je registrovan veliki otpor ispitanika i veliki broj odbijanja da se da odgovor ("Ne znam, ne sećam se, bilo je davno"), pogotovo kod ispitanika kod kojih su evidentirana lošija postignuća.
} 
Sprovodimo istraživanje u kojem se ispituje veza između uspeha na prijemnom ispitu i kasnijeg uspeha na studijama. Za sada nam je potrebno da se što tačnije prisetite broja bodova koji ste imali na prijemnom.

Druga grupa studenata radila je bez motivacione instrukcije - od njih je samo bilo traženo da upišu broj bodova i rang na prijemnom ispitu.

Podaci dobijeni od ispitanika upareni su sa fakultetskom evidencijom i svakom ispitaniku dodeljena je numerička šifra. Zatim je drugi istraživač radio dalju obradu podataka i analizu tako dobijene baze. Na taj način sačuvana je poverljivost podataka koje smo dobili od ispitanika.

\section{Zavisna varijabla}

Zavisna varijabla računata je kao razlika između saopštenih i realnih skorova. Ova razlika računala se jednostavnim oduzimanjem, ali s obzirom na nepouzdanost skorova razlike (Cronbach, 1957), sprovedena je i regresiona analiza sa saopštenim skorom kao prediktorom, a realnim kao kriterijumom, pa su reziduali sačuvani kao posebna promenljiva, koja je imala ulogu zavisne varijable. Na taj način izračunata razlika bi trebalo da u manjoj meri bude osetljiva na veličinu skorova.

\section{Rezultati}

\section{A. Izveštavanje o srednjoj školi}

\section{Koliko ispitanika greši ?}

Prvi korak u analizi rezultata bio je identifikovati potcenjivače, tačne izveštače i precenjivače i utvrditi njihov relativni odnos. Najstrože gledano, ovo je i osnovna provera naših hipoteza. Nezavisno od toga koliko ispitanici greše u proceni, trebalo je prvo utvrditi koliko njih to uopšte čini i da li je više onih koji su u tom procesu blagonakloni prema sebi. Tako smo formirali tri grupe ispitanika: u izveštavanju o prijemnom ispitu postojao je jedan stvarni rezultat (broj bodova) i jedan o kome ispitanici izveštavaju ${ }^{15}$ : potcenjivačima smo označili one koji su izvestili o manjem broju poena nego što su zaista imali, nezavisno od raspona greške, tačnim izveštačima smo označili one kod kojih su se ova dva parametra podudarila, a precenjivačima one koji su izvestili o većem broju poena nego što su imali. U izveštaju o

\footnotetext{
${ }^{15}$ Od ranga na listi smo odustali kada smo saznali da se rang liste nekoliko puta menjaju, dopunjavaju nakon dodatnih rokova za prijem i slično, pa se zabeleženi rang u junu kojim smo raspolagali ne može tretirati i kao definitivni rang.
} 
srednjoj školi, međutim, postojala su četiri parametra izveštavanja (uspeh u sve četiri godine školovanja), pa smo kao tačne izveštače označili one koji su sva četiri puta dali tačne izveštaje, kao potcenjivače one kod kojih je ukupna greška u izveštavanju bila na sopstvenu štetu, a kao precenjivače one kod kojih je greška bila u sopstvenu korist. U analizi podataka treba imati u vidu da je za svrstavanje u grupu tačnih izveštača bio postavljen vrlo strog uslov.

\section{Tabela 4}

Odnos potcenjivača, tačnih izveštača i precenjivača u izveštavanju o prijemnom ispitu $i$ proseku u srednjoj školi

\begin{tabular}{lcccc}
\hline & \multicolumn{2}{c}{ Prijemni ispit } & \multicolumn{2}{c}{ Prosek u četiri godine srednje škole* } \\
\cline { 2 - 5 } & Frekvencije & Procenat & Frekvencije & Procenat \\
\cline { 2 - 5 } Potcenjivači & 5 & 4.8 & 8 & 7.6 \\
Tačni izveštači & 20 & 23.8 & 5 & 4.8 \\
Precenjivači & 80 & 71.4 & 92 & 87.6 \\
\hline
\end{tabular}

Napomena. Ukupna greška u izveštavanju o prosečnoj oceni u sve četiri godine srednje škole. Tačni izveštači su oni koji su dali tačan izveštaj u sve četiri situacije

Uticaj memorijske dostupnosti. Iako je u trećoj godini ubedljivo najbrojnija kategorija precenjivača (Grafikon 2), ova razlika nije dostigla statističku značajnost.

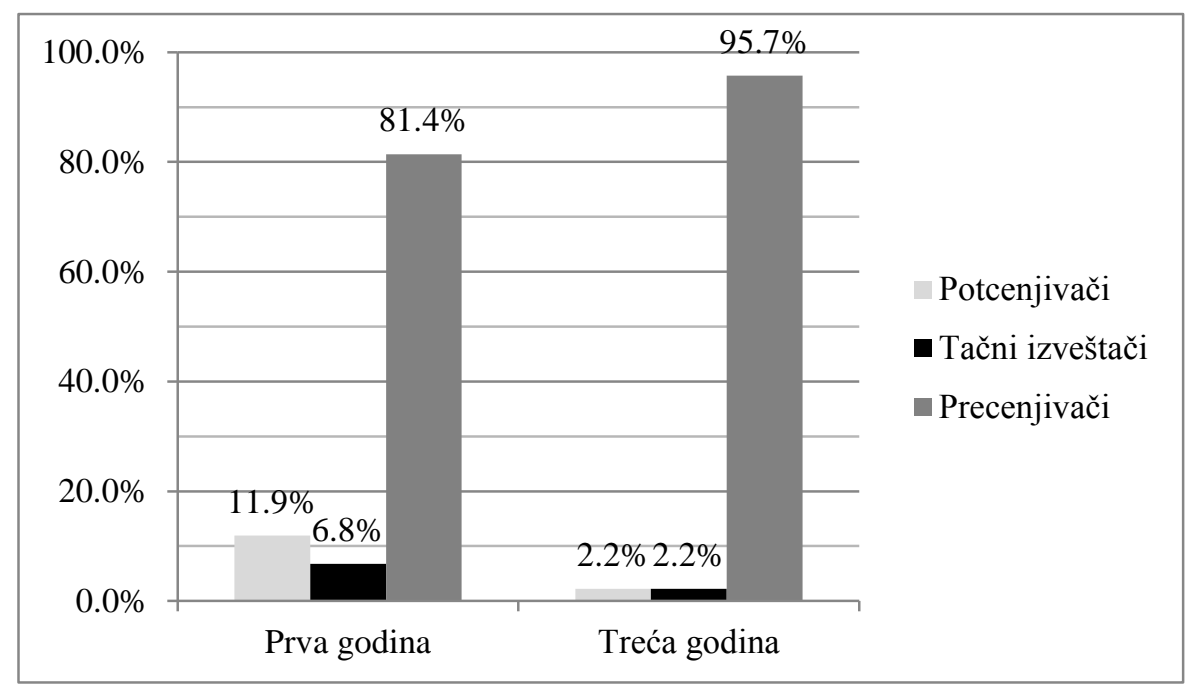

Grafikon 2. Zastupljenost potcenjivača, tačnih izveštača i precenjivača o uspehu iz srednje škole u zavisnosti od memorijske dostupnosti događaja. 
Uticaj instrukcije. Proporcionalna zastupljenost sve tri kategorije izveštača različita je u grupi koja je radila bez instrukcije, i u grupi kojoj je sugerisano da se događaja prisete što tačnije $\left(\chi^{2}(2)=11.687, p=.003\right)$. Efekat instrukcije bio je u očekivanom smeru: u obe grupe među netačnim izveštačima ima znatno više precenjivača, ali je ova disproporcija značajno veća u slučaju neometanog prisećanja nego u slučaju instrukcije "tačno" (Grafikon 3).

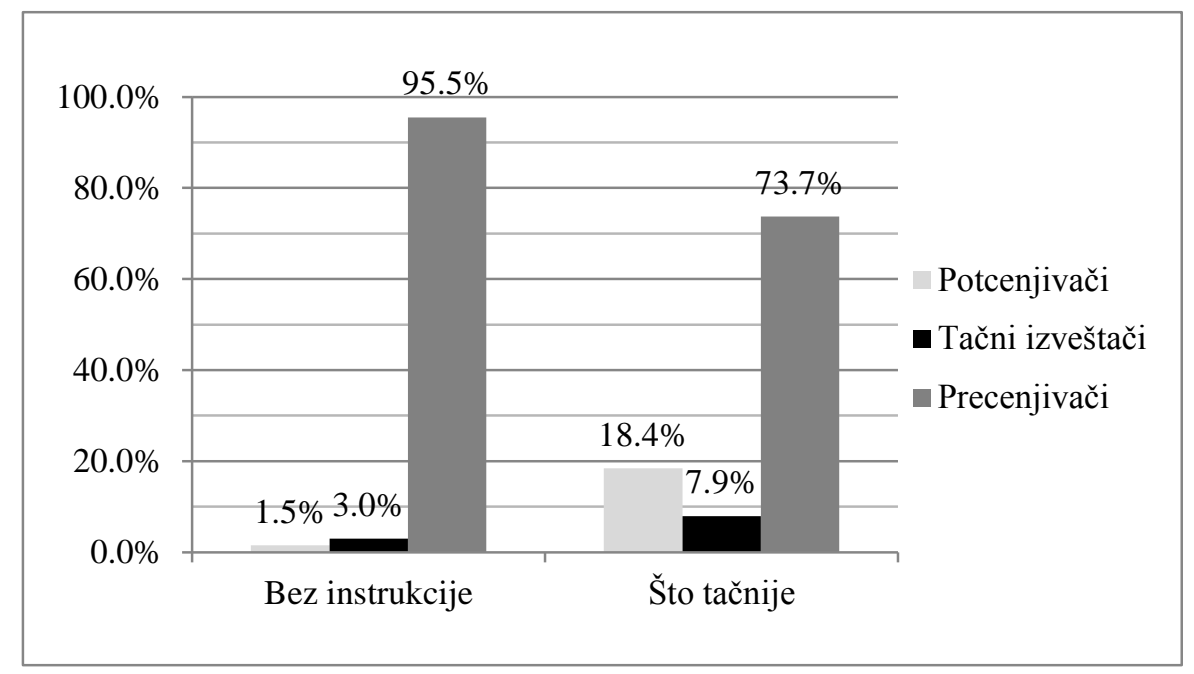

Grafikon 3. Zastupljenost potcenjivača, tačnih izveštača i precenjivača o uspehu iz srednje škole u zavisnosti od instrukcije.

\section{Koliko ispitanici greše? Intenzitet greške preterivanja}

Da bismo utvrdili da li se registrovana greška u izveštavanju značajno razlikuje od nule, uradili smo t-test za iste uzorke. U ukupnom izveštavanju o ocenama iz srednje škole $(t=7.62 ; p<.000)$, greška je bila značajno različita od nule, $\mathrm{i}$ to u očekivanom smeru (ispitanici su izveštavali o višim skorovima nego što su registrovani).

Intenzitet greške u zavisnosti od memorijske dostupnosti događaja i instrukcije za prisećanje. Da bismo utvrdili da li memorijska dostupnost događaja i instrukcija utiču na raspon greške u izveštavanju o ocenama iz srednje škole, uradili smo dvofaktorsku analizu varijanse. Instrukcija je dala značajan efekat: ispitanici koji su upućeni da se što tačnije prisete srednjoškolskog proseka, i kojima je u uputstvu naglašeno da je to veoma važno, davali su značajno tačnije izveštaje od onih kojima to nije naglašeno $(F(1,103)=6.33, p=.013)$ (Grafikon 4). Nasuprot očekivanjima, nije registrovana značajna razlika u izveštavanju studenata prve i treće godine (Grafikon 5), kao ni značajna interakcija među faktorima. 


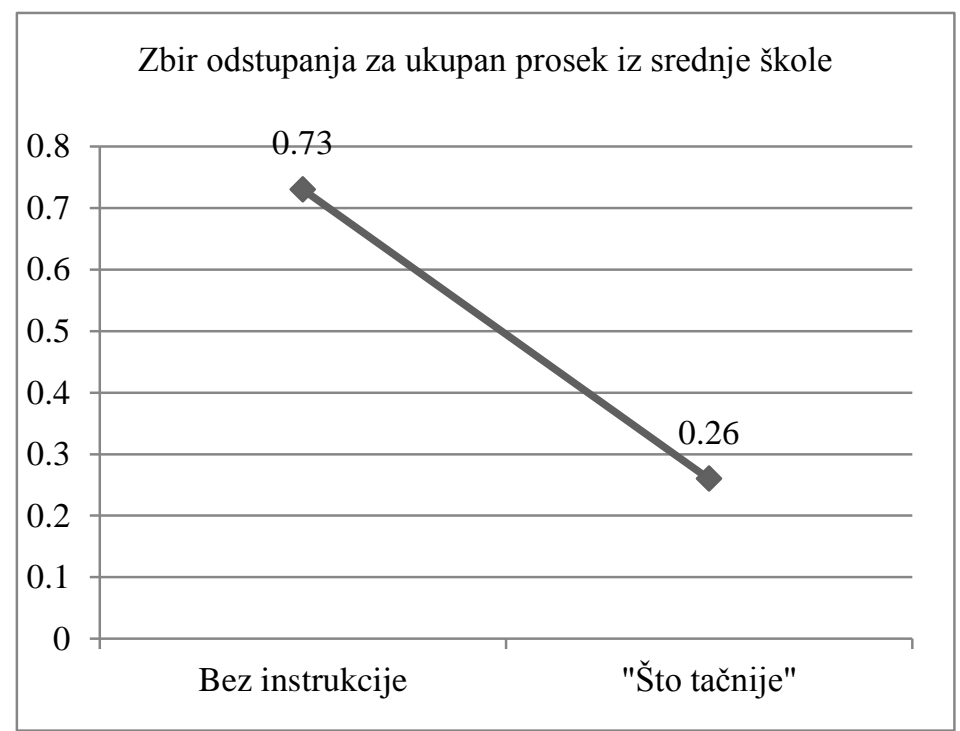

Grafikon 4. Greška preterivanja u izveštavanju o srednjoj školi u zavisnosti od instrukcije.

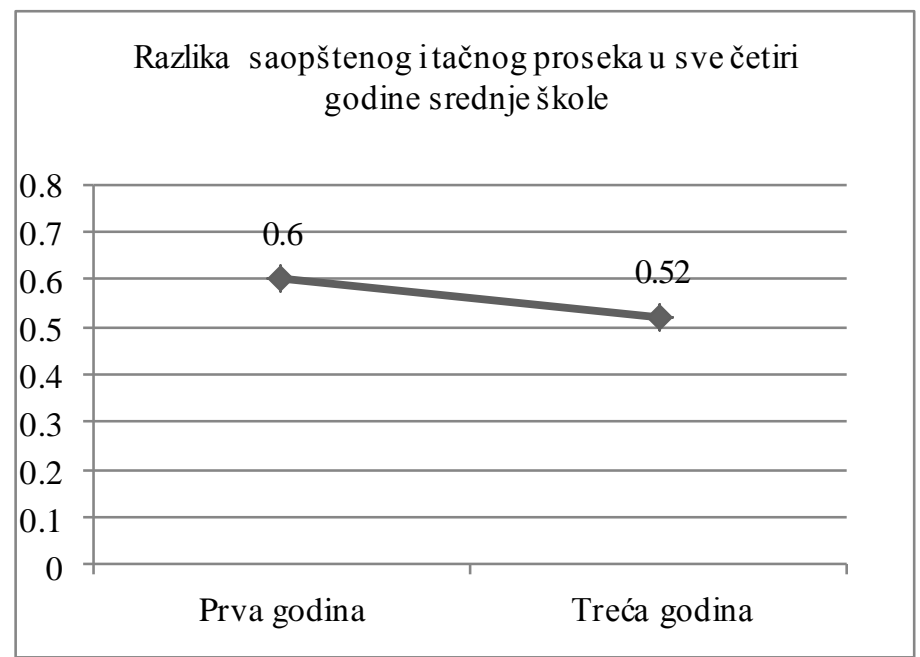

Grafikon 5. Greška preterivanja u izveštavanju o srednjoj školi u zavisnosti od memorijske dostupnosti.

\section{Apsolutna greška u izveštavanju o ocenama iz srednje škole}

Da bismo utvrdili kako nezavisne varijable utiču na grešku u izveštavanju nezavisno od njenog predznaka, odnosno da li se eksperimentalne grupe značajno razlikuju u tačnosti svog izveštaja, izračunali smo apsolutno odstupanje u izveštavanju o ocenama iz srednje škole. Kada se posmatra ovaj parametar ne može se zaključiti o tome da li ispitanici precenjuju ili potcenjuju svoj učinak, već koliko greše u svojim izveštajima. Pri tome treba uzeti o obzir činjenicu da je greška prve vrste (precenjivanje) značajno češća nego greška druge 
(potcenjivanje), pa zbog toga ne treba očekivati da ova analiza da značajno drugačije rezultate od analize relativnih grešaka.

Uticaj memorijske dostupnosti i instrukcije. Dvofaktorska analiza varijanse pokazala je da je grupa sa instrukcijom "što tačnije" zaista i davala tačnije izveštaje $(F(1,103)=5.03 ; p=.027)$, dok se studenti prve i treće godine nisu značajno razlikovali u apsolutnom odstupanju svojih izveštaja od tačnih podataka, niti je interakcija među faktorima bila značajna.

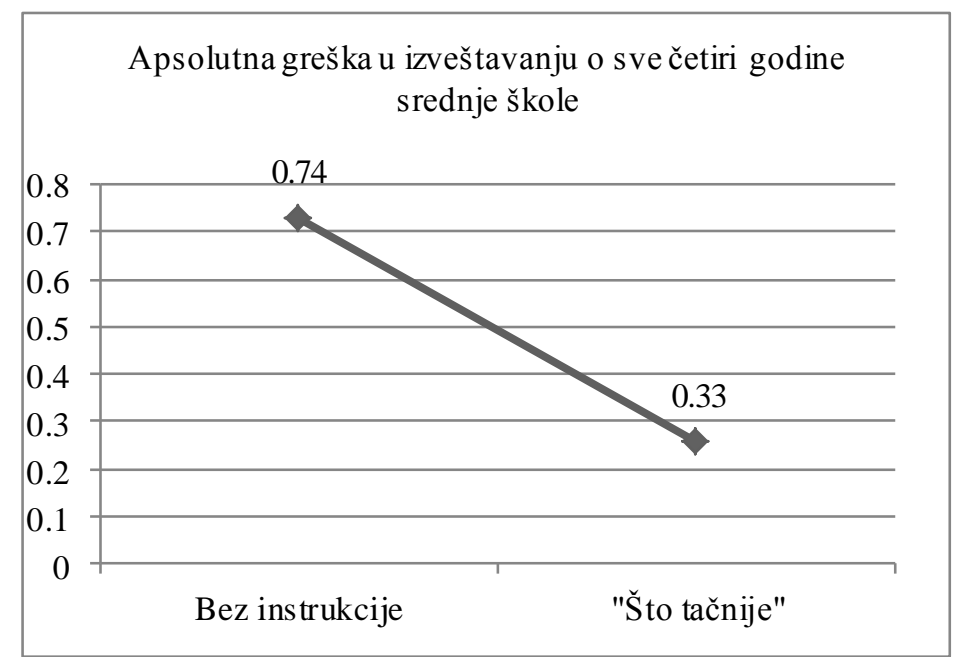

Grafikon 6. Apsolutna greška u izveštavanju ocenama iz srednje škole u zavisnosti od instrukcije.

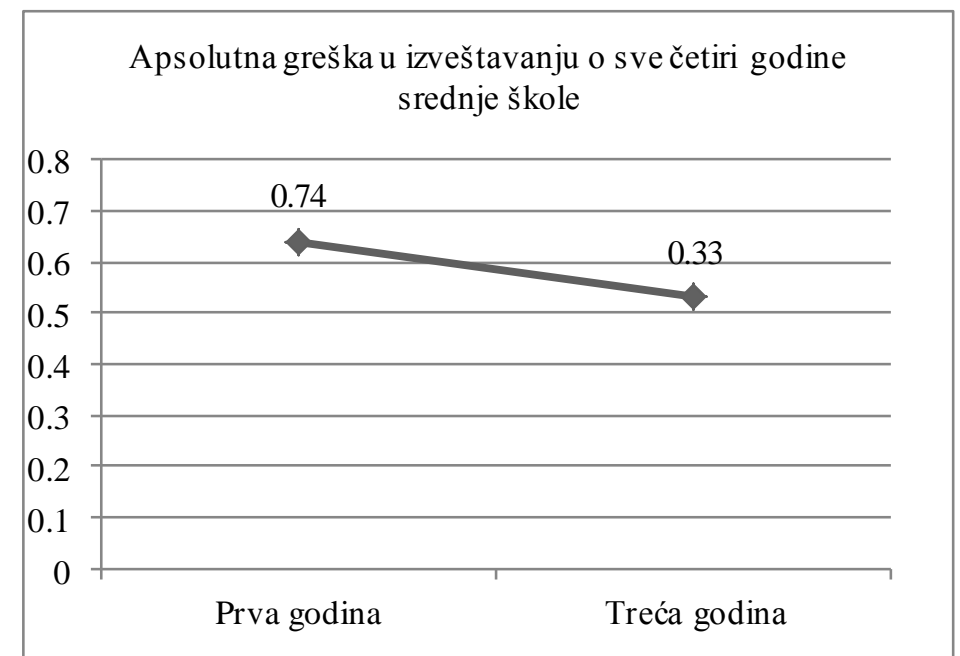

Grafikon 7. Apsolutna greška u izveštavanju o srednjoj školi u zavisnosti od memorijske dostupnosti. 


\section{B. Izveštavanje o prijemnom ispitu}

\section{Koliko ispitanika greši ?}

Uticaj memorijske dostupnosti. Kada je u pitanju izveštavanje o prijemnom ispitu, struktura izveštača nije se statistički značajno razlikovala u zavisnosti od memorijske dostupnosti događaja $\left(\chi^{2}(2)=3.69 ; p=.15\right)$, mada je među studentima treće godine bilo više precenjivača nego među studentima prve (85\% naspram $69 \%$, Grafikon 8 ).

Tabela 5

Odnos potcenjivača, tačnih izveštača i precenjivača u izveštavanju o prijemnom ispitu

\begin{tabular}{lcc}
\hline & \multicolumn{2}{c}{ Prijemni ispit } \\
\cline { 2 - 3 } & Frekvencije & Procenat \\
\cline { 2 - 3 } Potcenjivači & 5 & 4.8 \\
Tačni izveštači & 20 & 23.8 \\
Precenjivači & 80 & 71.4
\end{tabular}

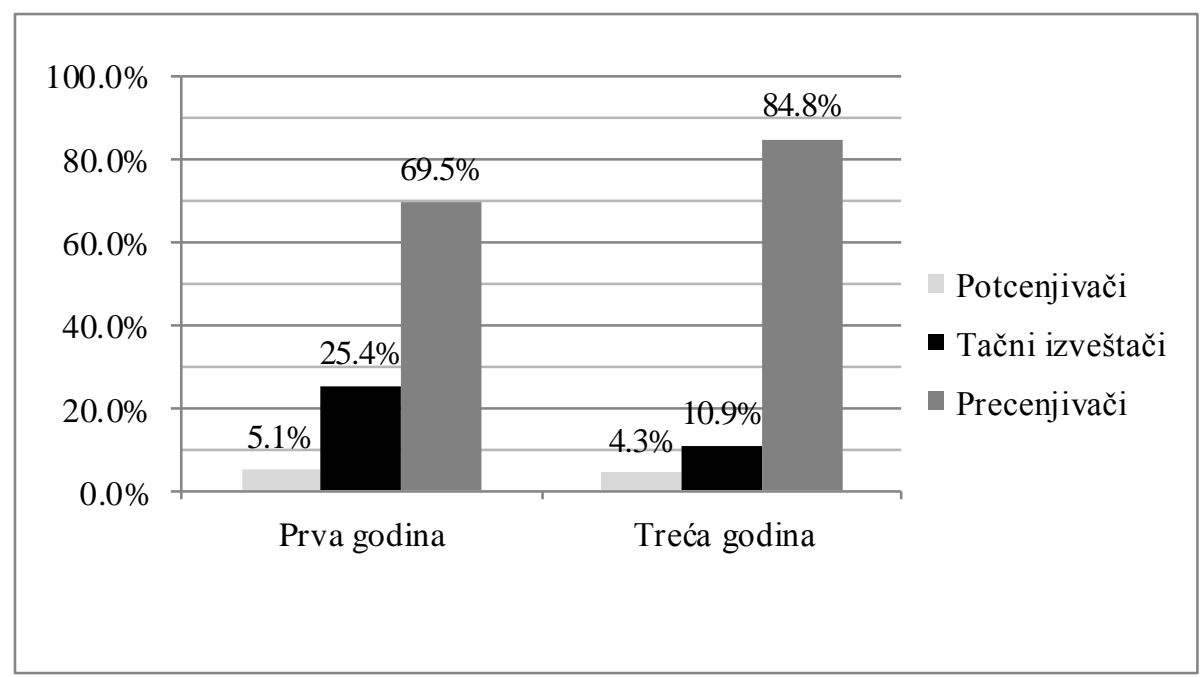

Grafikon 8. Zastupljenost potcenjivača, tačnih izveštača i precenjivača o uspehu iz srednje škole u zavisnosti od memorijske dostupnosti događaja. 
Uticaj instrukcije za prisećanje. Proporcija onih koji potcenjuju, precenjuju ili tačno izveštavaju o svom uspehu na prijemnom nije se razlikovala u zavisnosti od instrukcije koja im je data $\left(\chi^{2}(2)=1.55 ; p=.459\right)$ (Grafikon 9$)$.

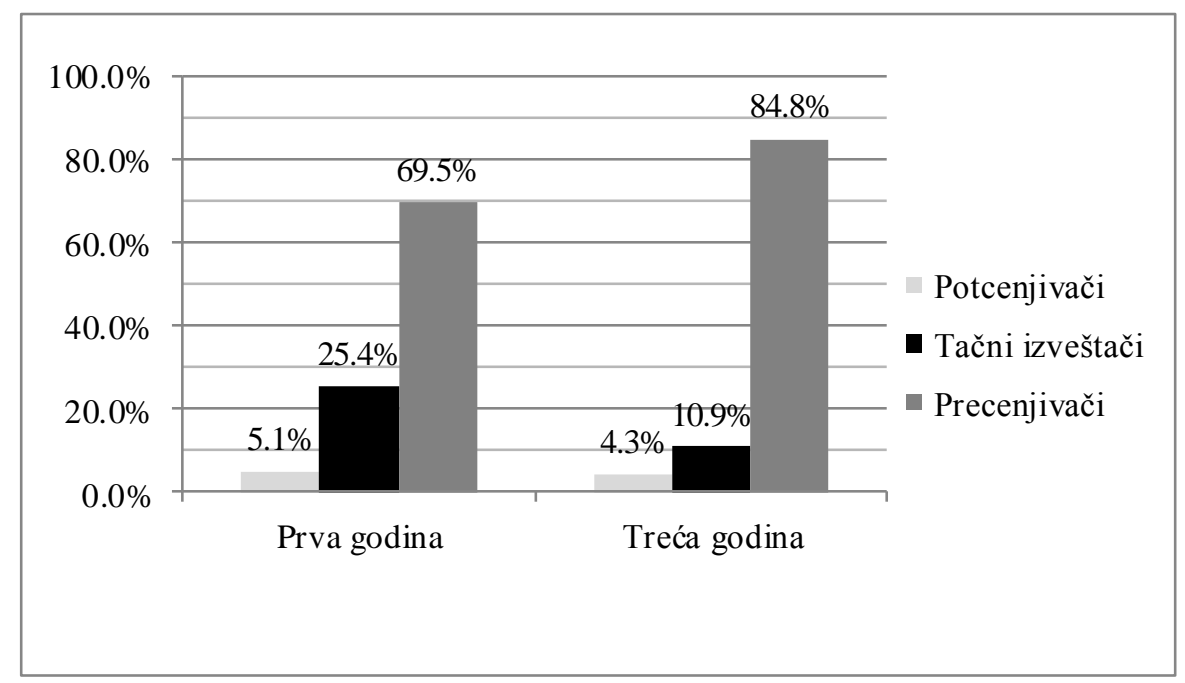

Grafikon 9. Zastupljenost potcenjivača, tačnih izveštača i precenjivača o uspehu iz srednje škole u zavisnosti od instrukcije za prisećanje.

\section{Koliko ispitanici greše? Intenzitet greške preterivanja}

Prvi korak u analizi ponovo je bio utvrditi da li se greška u izveštavanju značajno razlikuje od nule. T-test za iste uzorke pokazao je da je u ukupnom izveštavanju o ocenama sa prijemnog $(t=6.47 ; p=.000)$, greška bila značajno različita od nule, $\mathrm{i}$ to $\mathrm{u}$ očekivanom smeru (ispitanici su izveštavali o višim skorovima nego što su registrovani).

Intenzitet greške u zavisnosti od memorijske dostupnosti događaja i instrukcije za prisećanje. Dvofaktorska analiza varijanse pokazala je značajan efekat faktora memorijske dostupnosti $(F(1,103)=6.147, p=.015)$ (Grafikon 11): studenti treće godine izveštavali su o značajno većim postignućima na prijemnom nego studenti prve, dok instrukcija nije imala značajnog efekta. U ovoj analizi, međutim, dobijena je značajna interakcija među faktorima memorijske dostupnosti i instrukcije $(F(1,103)=4.533, p=.036)$ : u grupi studenata prve godine instrukcija nije imala efekta (jednako tačno su izveštavali sa i bez instrukcije), dok su studenti treće godine davali značajno tačnije izveštaje ukoliko im je instrukcija naglašavala da budu tačniji. 


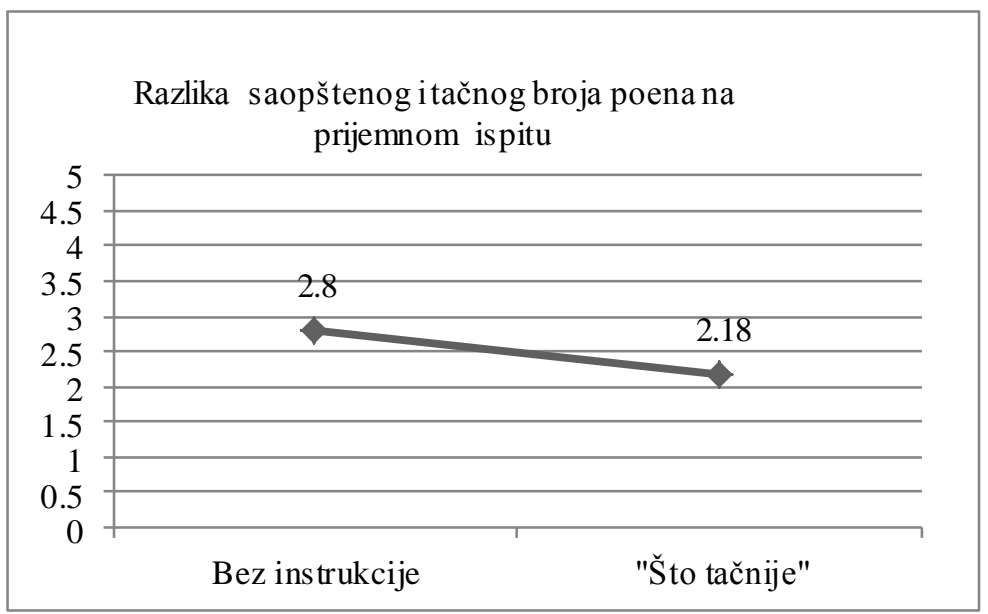

Grafikon 10. Greška preterivanja u izveštavanju o prijemnom u zavisnosti od instrukcije.

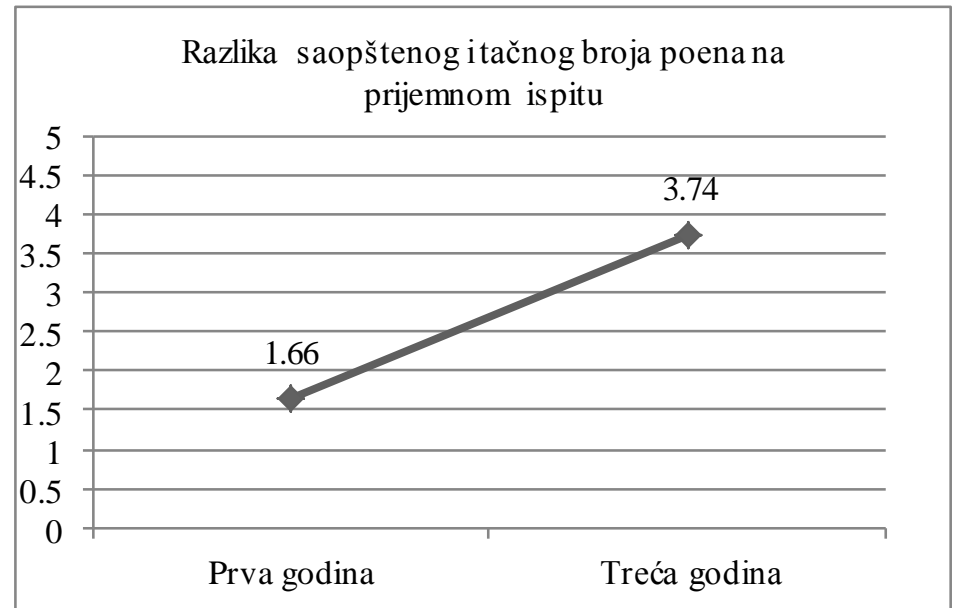

Grafikon 11. Greška preterivanja u izveštavanju o prijemnom u zavisnosti od memorijske dostupnosti.

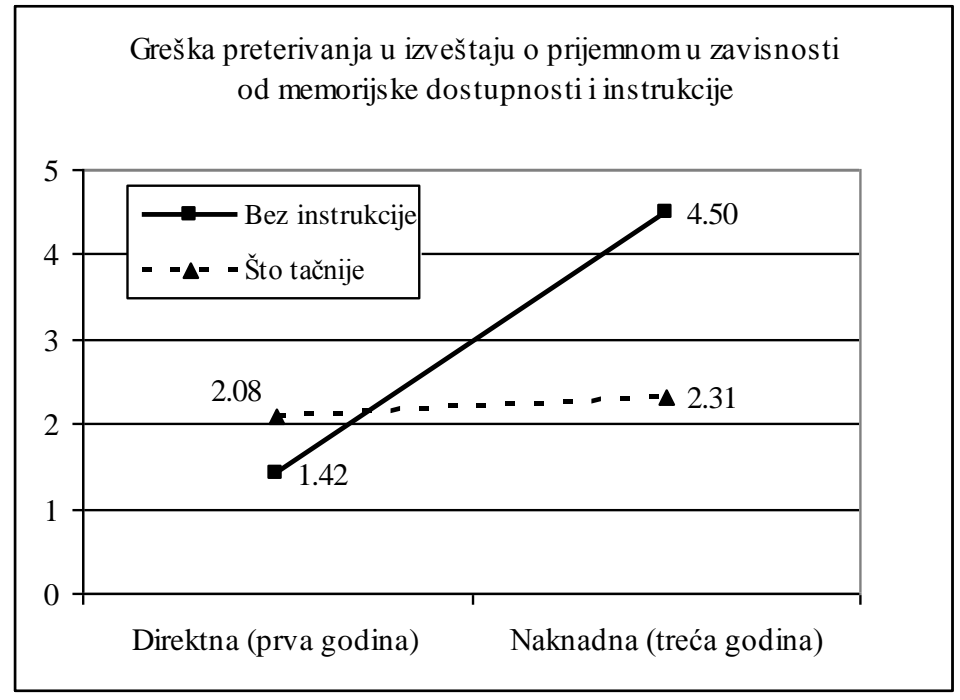

Grafikon 12. Greška preterivanja u izveštavanju o prijemnom u zavisnosti od memorijske dostupnosti događaja i instrukcije date za prisećanje. 
Greška preterivanja u zavisnosti od stvarnog uspeha $u$ aktivnosti. Iako je postojala restrikcija ranga, pre svega za uspeh na prijemnom, ali donekle i za srednjoškolski uspeh, činilo nam se smislenim da proverimo da li postoje razlike $u$ grešci preterivanja $u$ zavisnosti od uspešnosti u određenoj aktivnosti. Tako smo, koristeći tercilnu podelu (prema empirijskoj distribuciji stvarnih postignuća, podelili smo ispitanike u tri grupe jednake veličine) formirali grupe za poređenje, koje smo uslovno nazvali "lošim", "umereno dobrim" i "dobrim"16. Razlika između ove tri grupe pokazala se statistički značajnom kada je u pitanju srednjoškolski uspeh $(F(2,104)=4.898 ; p=.009)$, a nije dostigla značajnost, iako je registrovan očekivan trend, kada je u pitanju izveštavanje o prijemnom ispitu (Grafikoni 13 i 14); ni parcijalna poređenja u post hoc testovima nisu dostigla značajnost.

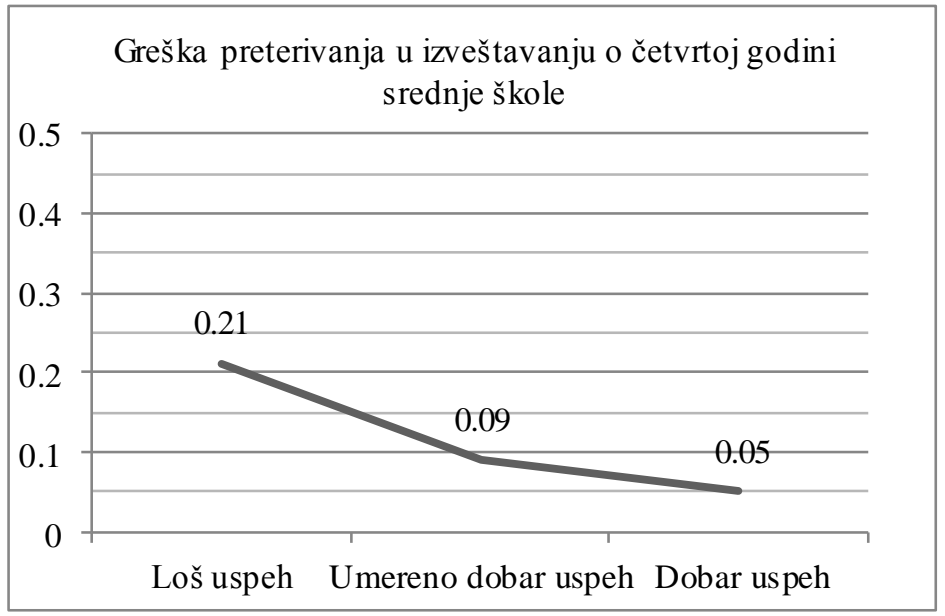

Grafikon 13. Greška preterivanja u izveštavanju o srednjoj školi u zavisnosti od uspeha.

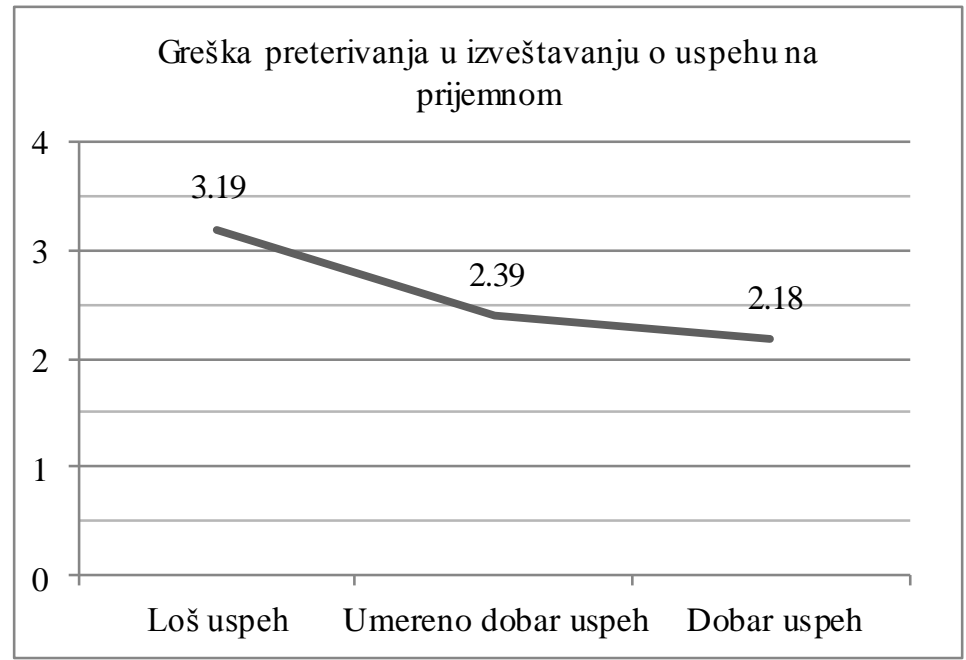

Grafikon 14. Greška preterivanja u izveštavanju o prijemnom ispitu u zavisnosti od uspeha.

\footnotetext{
${ }^{16}$ U grupu "loših" prema uspehu iz srednje škole spadaju svi koji su imali prosek ispod 4, između 4.01 i 4.5 "umereno dobri", a iznad 4.5 "dobri"; prema postignuću na prijemnom ispitu u grupi "loših" su svi koji su imali ispod 76 poena, "umereno dobri", između 76.1 i 86 poena, a "dobri" svi iznad 86.
} 


\section{Apsolutna greška u izveštavanju o postignuću na prijemnom ispitu}

$\mathrm{Na}$ isti način na koji smo izračunali apsolutno odstupanje u izveštavanju ocenama iz srednje škole, izračunali smo i apsolutno odstupanje u izveštavanju o postignuću na prijemnom ispitu.

Uticaj memorijske dostupnosti $i$ instrukcije za prisećanje. Studenti prve godine bili su značajno tačniji od studenata treće $(F(1,103)=5.567 ; p=.019)$; iako je instrukcija delovala u očekivanom smeru njen efekat nije dostigao značajnost. Interakcija ova dva faktora bila je marginalno značajna $(F(1.103)=2.908 ; p=.091)$

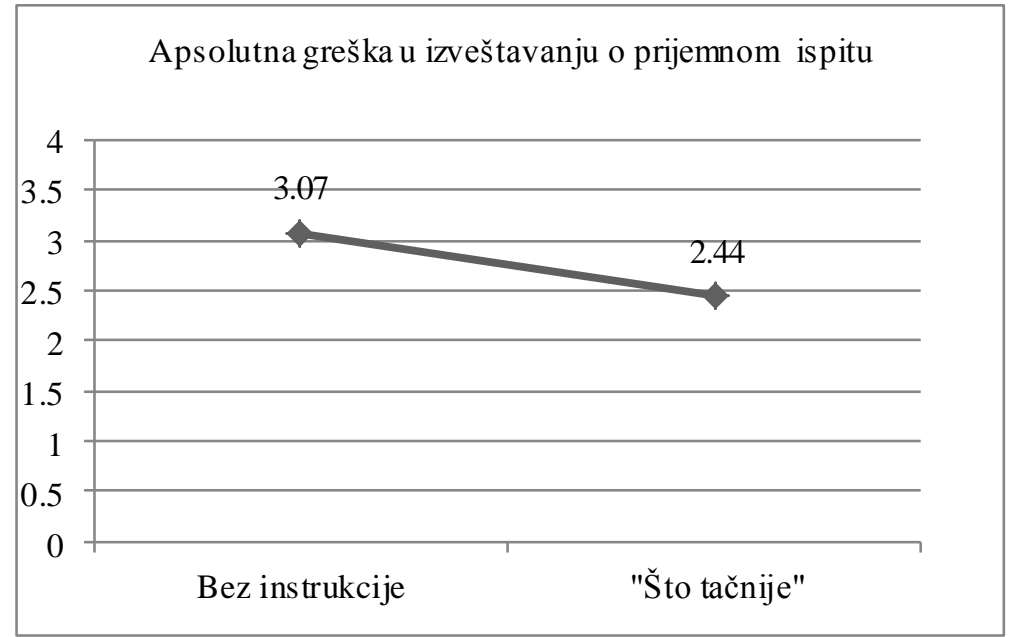

Grafikon 15. Apsolutna greška u izveštavanju o prijemnom ispitu u zavisnosti od instrukcije.

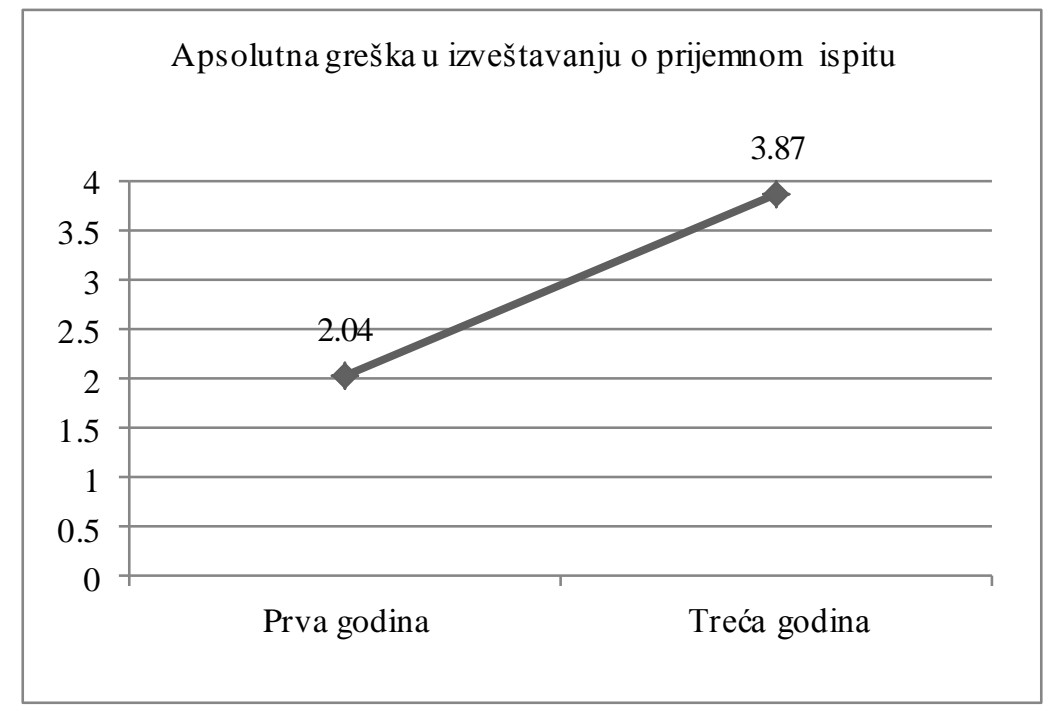

Grafikon 16. Apsolutna greška u izveštavanju o prijemnom ispitu u zavisnosti memorijske dostupnosti. 


\section{Analiza sa rezidualima kao promenljivim.}

Smatrali smo da je u ovom ogledu, pošto je zadatak ispitanika bio da izveštavaju o realnim postignućima, potrebno analizirati podatke uzveši u obzir i raspon moguće greške koju je određivala visina njihovog inicijalnog postignuća. Zbog toga smo kao zavisne promenljive uključili reziduale iz regresione analize u kojoj su pravi skorovi služili kao prediktori, a saopšteni kao kriterijumi. Analiza varijanse, međutim, dala je rezultate koji su u potpunosti podudarni sa analizom u kojima je relativni iznos greške bio zavisna promenljiva (Tabela 4.4, Prilog 4).

\section{Povezanost sklonosti ka grešci preterivanja sa indikatorima psihološke adaptiranosti}

Odstupanja u izveštavanju o dve vrste postignuća (srednjoškolski uspeh i uspeh na prijemnom ispitu) međusobno su značajno povezana (Tabela 6); takođe su izrazito i značajno povezana sa drugim indeksom pristrasnosti sećanja (udelom pozitivnih autobiografskih epizoda u ukupnom korpusu spontano navedenih autobiografskih sećanja).

Precenjivanje srednjoškolskog uspeha je značajno povezano sa većim akademskim ambicijama, ukupnim životnim optimizmom i dominantnim raspoloženjem (marginalno značajno). Precenjivanje uspeha na prijemnom ispitu značajno je povezano sa većim akademskim ambicijama. 
Tabela 6

Matrica korelacija: povezanost indikatora memorijskih pristrasnosti u izveštavanju o uspehu na prijemnom ispitu i srednjoj školi sa indikatorima psihološke adaptiranosti

\begin{tabular}{|c|c|c|c|c|c|c|}
\hline & $\begin{array}{c}\text { Skor na } \\
\text { skali } \\
\text { Akademskih } \\
\text { ambicija }\end{array}$ & $\begin{array}{c}\text { Skor na } \\
\text { Rozenbergo-voj } \\
\text { skali } \\
\text { samopoštovanja }\end{array}$ & $\begin{array}{l}\text { Skor na skali } \\
\text { LOT (životnog } \\
\text { optimizma) }\end{array}$ & $\begin{array}{l}\text { Skor na skali } \\
\text { dominantnog } \\
\text { raspoloženja }\end{array}$ & $\begin{array}{c}\text { Broj pozitivnih/ } \\
\text { ukupan broj } \\
\text { spontano } \\
\text { navedenih } \\
\text { sećanja }\end{array}$ & $\begin{array}{c}\text { Razlika } \\
\text { saopštenog i } \\
\text { tačnog broja } \\
\text { poena na } \\
\text { prijemnom }\end{array}$ \\
\hline $\begin{array}{l}\text { Zbir odstupanja za } \\
\text { ukupan prosek iz } \\
\text { srednje škole }\end{array}$ & $.35(* *)$ & -.05 & $.33(* *)$ & $.17\left(^{-}\right)$ & $.58(* *)$ & $.33(* *)$ \\
\hline $\begin{array}{l}\text { Razlika saopštenog i } \\
\text { tačnog broja poena } \\
\text { na prijemnom }\end{array}$ & $.17\left(^{-}\right)$ & .01 & .06 & .01 & $.48(* *)$ & \\
\hline
\end{tabular}

\section{Predviđanje raspona greške preterivanja}

Gotovo 30\% varijanse greške u izveštavanju o srednjoškolskom uspehu objašnjeno je skupom prediktorskih varijabli $\left(R^{2}=.284, F(7,103)=5.44, p=.000\right)$, od kojih su značajan doprinos dale dve: indeks pozitivnosti spontano navedenih autobiografskih sećanja $(\beta=.46$, $p=.000)$ i instrukcija data za prisećanje $(\beta=.19, p=.038)$. 


\section{Tabela 7}

Regresiona analiza sa greškom preterivanja u izveštaju o srednjoj školi kao zavisnom varijablom

\begin{tabular}{ccccc}
$\begin{array}{c}\text { Nestandardizovani } \\
\text { koeficijenti }\end{array}$ & $\begin{array}{c}\text { Standardizovani } \\
\text { koeficijenti }\end{array}$ & & \\
\hline B & SE (B) & $ß$ & $\mathrm{t}$ & $\mathrm{p}$ \\
\hline-.47 & .93 & & -.50 & .62
\end{tabular}

Godina studija (memorijska dostupnost dogadjaja)

$-.17$

.16

$-.09$

$-1.05 \quad .30$

Instrukcija data za prisećanje

$-.34$

.16

$-.19$

$-2.10$

.04

Skor na skali LOT (životnog optimizma)

$-.03$

.03

$-.11$

$-.96$

Broj pozitivnih/ukupan broj spontano navedenih sećanja

Skor na skali dominantnog

raspoloženja

$.00 \quad .01$

.03

$.29 \quad .78$

Skor na Rozenbergovoj skali

samopoštovanja

Skor na skali Akademskih ambicija

Polovina varijanse greške u izveštavanju o broju bodova na prijemnom ispitu objašnjeno skupom prediktorskih varijabli $\left(R^{2}=.49, F(7,103)=13.64, p=.000\right)$, od kojih su značajan doprinos dali: pozitivnost spontano evociranih autobiografskih sećanja, opšti životni optimizam, memorijska dostupnost događaja i nivo samopoštovanja (Tabela 8). 
Tabela 8

Regresiona analiza sa greškom preterivanja u izveštaju o prijemnom ispitu kao zavisnom varijablom

\begin{tabular}{|c|c|c|c|c|c|}
\hline & $\begin{array}{r}\text { Nesta } \\
\text { kc }\end{array}$ & $\begin{array}{l}\text { ardizovani } \\
\text { cijenti }\end{array}$ & $\begin{array}{c}\text { Standardizovan } \\
\text { i koeficijenti }\end{array}$ & & \\
\hline & B & SE (B) & B & $\mathrm{t}$ & $\mathrm{p}$ \\
\hline & -7.11 & 3.01 & & -2.36 & .02 \\
\hline $\begin{array}{l}\text { Godina studija (memorijska } \\
\text { dostupnost dogadjaja) }\end{array}$ & 1.55 & .51 & .22 & 3.05 & .00 \\
\hline Instrukcija data za prisećanje & .33 & .53 & .05 & .62 & .54 \\
\hline $\begin{array}{l}\text { Skor na skali LOT (životnog } \\
\text { optimizma) }\end{array}$ & .26 & .11 & .23 & 2.44 & .02 \\
\hline $\begin{array}{l}\text { Broj pozitivnih/ukupan broj spontano } \\
\text { navedenih sećanja }\end{array}$ & 7.66 & 1.24 & .48 & 6.20 & .00 \\
\hline $\begin{array}{l}\text { Skor na skali dominantnog } \\
\text { raspoloženja }\end{array}$ & -.03 & .03 & -.09 & -1.07 & .30 \\
\hline $\begin{array}{l}\text { Skor na Rozenbergovoj skali } \\
\text { samopoštovanja }\end{array}$ & -.15 & .06 & -.23 & -2.59 & .01 \\
\hline Skor na skali Akademskih ambicija & .20 & .11 & .14 & 1.80 & .08 \\
\hline
\end{tabular}




\section{Diskusija}

Merenje pristrasnosti u samoevaluaciji. Za merenje pristrasnosti u samoevaluaciji odabrali smo broj bodova sa prijemnog ispita i prosečan uspeh u srednjoj školi. S obzirom da su u pitanju objektivni, specifični i proverljivi parametri, to nam je omogućilo da rešimo nekoliko problema koji su karakteristični za drugačije pristupe merenju tačnosti samoevaluacije. Na ovaj način mogli smo da razlikujemo studente koji precenjuju sopstveni uspeh od onih koji tačno izveštavaju o svojim visokim postignućima (individualne mere preterivanja nisu nam dostupne ako merimo "efekat nadprosečnosti", na primer - ovakvi parametri ukazuju na to da većina populacije sebe vidi kao nadprosečne, ali ne i na to ko je u toj proceni u pravu a ko nije). Drugim rečima, neutralisali smo problem tačnosti koji je prisutan u normativnom modelu. Pored toga, sa više sigurnosti smo mogli da tvrdimo da su studenti zapravo izveštavali o istom atributu i da je njihova percepcija tog atributa odgovarala eksternom kriterijumu na osnovu kog smo utvrđivali postoji li greška u izveštavanju (ovakvo poklapanje nije garantovano ako poredimo samoprocene ispitanika na dimenziji "društvenost", na primer, sa procenama nezavisnih posmatrača). Na taj način, prevaziđen je problem nepodudarnosti u predmetu merenja, karakterističan za model socijalnog konsenzusa.

S druge strane, ovako precizno operacionalno definisanje kriterijuma ima i svojih ograničenja. Pre svega, značajno sužava predmet merenja: umesto širokih dispozicija, prediktivnih za ponašanje, ispitanici izveštavaju o konkretnim postignućima. Pored toga, ne postoje prihvatljivi objektivni kriterijumi za mnoge značajne psihološke fenomene (fizičku atraktivnost ili smisao za humor, na primer). Imajući to na umu, međutim, treba naglasiti da je cilj istraživanja bio upravo da pokaže da su ljudi skloni preterivanju čak i na ovako jasno operacionalizovanim kriterijumima; ta činjenica nam dozvoljava da pretpostavimo da bi ova tendencija bila još izraženija ukoliko su kriterijumi manje jasno definisani, a procena postignuća proizvoljnija.

Pošto u ovom ogledu nismo manipulisali skorovima ispitanika, već smo koristili njihova stvarna postignuća, bilo je najviše smisla kontrolisati visinu postignuća kao limitirajući faktor opsega greške; analiza na rezidualima kao zavisnim promenljivim dala je iste rezultate kao i analiza na diferencijalnom skoru kao zavisnoj.

Naši nalazi vrlo ubedljivo govore $u$ prilog postojanju tendencije ka pristrasnom pamćenju prošlih postignuća: broj ispitanika koji izveštavaju o većim rezultatima nego što su zaista postigli višestruko premašuje broj ispitanika koji tačno izveštavaju ili potcenjuju svoje rezultate (procenat precenjivača kretao se od 71 do 87 ). Ovakav odnos odgovara odnosima 
dobijenim u sličnim istraživanjima: tako na primer Barik sa saradnicima (Bahrick t al., 1996) izveštava da je u testiranju koje se odvijalo nekoliko godina nakon završetka srednje škole, 79 od 99 učesnika povećalo svoje školske ocene, šest je umanjilo ocene a 13 ih je tačno reprodukovalo; u drugom istraživanju (Willard \& Gramzow, 2008) 55\% studenata je precenilo, $24 \%$ tačno izvestilo a $21 \%$ potcenilo svoj SAT skor ${ }^{17}$. Iako je u pitanju gruba mera, upravo je proporcija precenjivača mera koja dozvoljava smislena poređenja sa rezultatima drugih istraživanja, izvedenim u drugim kulturama i na drugačijim parametrima. Ukoliko je, naime, analiza rađena sa ciljem da se utvrdi intenzitet precenjivanja, onda je takva analiza osetljiva na sistem merenja: u SAD se školske ocene izražavaju u alfabetskom sistemu, sa četiri grube kategorije (A,B,C,D) i u nekim slučajevima međukategorijama (dodavanje + ili -)- verovatnoća greške i njen raspon svakako su manji u poređenju sa našim metričkim ocenjivanjem, u kome se prosek računa sa tačnošću od dve decimale. Toga su svesni i istraživači (Bahrick et al., 1996) kada prave poređenja između tačnosti prisećanja američkih i nemačkih studenata: procenat tačno reprodukovanih ocena značajno je niži u nemačkim istraživanjima (Schmela, 1993), ali autori to pripisuju većoj varijabilnosti ocena u nemačkom školstvu, dok je odnos među precenjivačima i potcenjivačima relativno stabilan i u većini slučajeva ubedljivo na strani precenjivača.

Ukoliko analiziramo raspon memorijskih distorzija, međutim, slika postaje unekoliko drugačija: u izveštavanju o uspehu na prijemnom ispitu, prosečan skor koji navode ispitanici razlikuje se za dva boda od stvarnog skora, dok je u izveštavanju o srednjoj školi ukupna greška 0.58 (otprilike za 0.15 po godini). Treba uzeti u obzir restrikcije u rasponu izveštavanja: ispitanici su znali da je minimum mogućih bodova bio preko 60 , u slučaju prijemnog, a da je srednjoškolski prosek takođe morao da prelazi minimum od 12 za sve četiri godine. Uprkos tome, nalazi sugerišu da se pamćenje modifikuje diskretno, tako da opšti ton ostane nepromenjen. Drugim rečima, ne treba žuriti sa zaključkom da je pamćenje strahovito nepouzdano- utvrđene sistematske distorzije zapravo ne odstupaju previše od realnih skorova.

Faktori koji utiču na grešku preterivanja. Što se tiče uticaja motivacije za tačnošću i memorijske dostupnosti događaja na grešku preterivanja, registrovali smo relativno neočekivan obrazac: u izveštavanju o srednjoškolskom uspehu, delovala je instrukcija, pa su ispitanici tačnije izveštavali kada im je to sugerisano, a nije bilo razlike u tačnosti izveštaja studenata prve i treće godine. U izveštavanju o broju bodova na prijemnom, međutim, bilo je

\footnotetext{
${ }^{17}$ Rezultat nacionalnog testiranja znanja iz matematike i engleskog kao i sposobnosti logičkog mišljenja. Odvija se u SAD nakon završetka srednje škole i predstavlja jedan od glavnih parametara selekcije za upis na fakultet.
} 
značajne razlike prema memorijskoj dostupnosti (više su grešili stariji studenti) i utvrđena je značajna interakcija: kod starijih studenata delovala je instrukcija, a kod mlađih ne. Moguće je da je ovakva slika posledica razlika u stvarnoj vremenskoj udaljenosti događaja iz srednje škole i prijemnog ispita: mi smo u nacrtu rešili da tretiramo ove događaje kao jednako uvremenjene, zato što su studenti dužni da pri aplikaciji za fakultet navedu srednjoškolski prosek $\mathrm{i}$ to je jedna od komponenti konačnog broja poena. Možda ta odluka nije bila $\mathrm{u}$ potpunosti ispravna, pa je zapravo srednja škola dovoljno udaljena u pamćenju i jedne i druge grupe studenata, toliko da među njima ne treba očekivati razlike, dok je prijemni ispit kao životni događaj (a ne izveštavanje o njemu) zaista bliži studentima prve godine. S druge strane, moguće je i da je uspeh na prijemnom ispitu značajnija komponenta slike o sebi starijih studenata, pa je ova grupa i više motivisana da ispolji pristrasnost u samoizveštavanju kada je u pitanju ovo postignuće. Ovo bi donekle objasnilo i efekat instrukcije u ovoj grupi i njegov izostanak u grupi mlađih studenata. Na kraju, sve registrovane razlike su bile u očekivanom smeru, pa je moguće i da nisu dostigle značajnost samo zbog ograničenja u veličini uzorka.

Kada je u pitanju predviđanje raspona greške preterivanja, prediktorski skup koji su pored nezavisnih varijabli kojima smo manipulisali u ogledima (memorijska dostupnost i instrukcija), činile i dispozicione varijable odabrane tako da predstavljaju pokazatelje dobre psihološke adaptiranosti, ili strože posmatrano, opšteg pozitivnog odnosa prema sebi, objasnio je značajan procenat varijanse: $30 \%$ greške u izveštavanju o srednjoškolskom uspehu i čak 50\% greške u izveštavanju o bodovima na prijemnom. Kao najznačajniji "dispozicioni" prediktor pokazao se indeks pozitivnosti spontanih autobiografskih sećanja. Uzimajući u obzir koliko su dva pokazatelja greške u pamćenju različito operacionalizovana: jedan kao razlika stvarnog i saopštenog skora, a drugi kao udeo sećanja pozitivne valence u skupu spontano evociranih autobiografskih događaja, ovaj nalaz ukazuje na postojanje jedinstvene tendencije ka "ulepšavanju" prošlosti, koja se ispoljava u sasvim različitim domenima. Drugi značajan prediktor je opšti životni optimizam, što može ukazivati na to da pristrasno prekrajanje prošlosti utiče na pozitivnija očekivanja od budućnosti (ovo je ujedno i srž Tejlor Braunove hipoteze - pozitivne iluzije o sebi omogućavaju nam proaktivni pristup u životu), mada postoje nalazi o kojima je bilo reči, da optimisti u izvesnim slučajevima, posežu za "retroaktivnim pesimizmom" (Sanna \& Chang, 2003) da bi održali sliku o sebi kao osobama koje se stalno usavršavaju, umanjili nelagodnost izazvanu neuspehom ili da bi imali niže standarde za poređenje budućih postignuća. U našem eksperimentalnom dizajnu nije kreirana situacija koja bi provocirala ovakve reakcije, pa je dobijena jednoznačna povezanost 
između dve vrste temporalnih pristrasnosti. Akademske ambicije nisu dale specifičan doprinos predviđanju opsega greške preterivanja, ali je utvrđena značajna korelacija nivoa akademskih ambicija sa greškom preterivanja izmerenom u oba domena (školski uspeh i prijemni ispit). Nivo samopoštovanja i pozitivnost dominantnog raspoloženja su marginalno značajno korelirali sa greškom preterivanja; ovo može biti rezultat nedovoljne diskriminativnosti instrumenata, o ćemu će biti više reči kasnije. U istraživanjima koja su po metodologiji najsličnija našem, dobijena je značajna, iako ne velika korelacija između preterivanja u izveštavanju o prosečnoj oceni na studijama i motiva za postignućem $(r=.19$, $p=.000)$, kao i negativna korelacija sa negativnošću dominantnog $\operatorname{afekta}^{18}(r=-.32, p=.000)$ (Gramzow \& Willard, 2008); korelacija između pozitivne distorzije u izveštavanju o srednjoškolskom uspehu takođe je pozitivno korelirala sa zadovoljstvom sopstvenim uspehom na studijama ( $r=.38, p=.000)$ (Bahrick et al., 2008).

\footnotetext{
${ }^{18}$ Ovo naglašavamo jer je postojao i indeks pozitivnosti dominantnog afekta kao nezavisna mera.
} 


\section{Eksperiment 2}

\section{Dizajn}

U drugom ogledu eksperimentalno se provocirala greška preterivanja. Dizajn je bio 2 (skor se saopštava javno ili privatno) x 2 (visoko i nisko involvirana grupa) x 2 (dostupnost: jednoj grupi se podaci uzimaju neposredno nakon testiranja, a drugoj nedelju do dve nakon testiranja). Da bi se grupe razlikovale u pogledu motivacije za samoprikazivanjem, jedna grupa je saopštavala svoj skor privatno (u okviru pismenog retesta), a druga javno (u okviru intervjua sa eksperimentatorom prilikom retesta).

\section{Stimulus materijal}

Involviranošću smo manipulisali preko izbora sadržaja testa. U pilot testiranju četrdeset šest apsolvenata psihologije procenjivali su na 10-stepenoj skali sa polovima "uopšte nije značajna" $i$ "veoma je značajna" koje su sposobnosti značajne, a koje manje značajne za sliku o sebi. Na osnovu njihovih procena kreirali smo dva testa: opšte intelektualne sposobnosti, kao mere visoko značajne sposobnosti $(M=8.7, S D=1.2)$ i vizuelno perceptivne sposobnosti, kao umereno značajne $(M=5.2, S D=2.6)$. Izbor sposobnosti koja je manje značajna za sliku o sebi pokazao se kao prilično izazovan posao, s obzirom da je ta sposobnost morala ipak biti dovoljno značajna da neko razvije test za njeno merenje i da taj test deluje ubedljivo. Stoga se nismo opredelili za sposobnosti sa dna liste, koje su ispitanici markirali kao malo ili nimalo značajne za sliku o sebi.

Uz pomoć istraživača saradnika za potrebe ovog istraživanja u programu Superlab 4.0 kreirana su oba testa.

\section{Procedura i učesnici}

U ovom ogledu učestvovalo je 137 studenata treće godine psihologije, sa Fakulteta za medije i komunikaciju i Filozofskog fakulteta u Beogradu, koji su slučajnim izborom raspoređeni u jednu od eksperimentalnih grupa (broj ispitanika po grupi dat je u Tabeli 4.2 u Prilogu 4).

Test opšte intelektualne sposobnosti počinjao je sledećim usmenim uputstvom:

U okviru ovog istraživanja mi koristimo kratku verziju testa opšte kognitivne sposobnosti, koja se pokazala kao dobar prediktor akademskog uspeha u zemljama 
engleskog govornog područja. Prilikom adaptacije, testiramo opštu populaciju, pa to uključuje i studente.

Na kraju svakog bloka zadataka i na kraju celog testa dobićete povratnu informaciju o uspehu. Ona neće biti izražena kao skor ili procenat tačnih zadataka, već kao Vaš položaj u ispitanoj populaciji (percentil). Dakle, ispis na ekranu ce vam reći na kom percentilu se nalazi Vaš rezultat, odnosno od koliko procenata populacije ste uspešnije uradili test. S obzirom da ste vi pozitivno selekcionisana grupa, možete ocekivati da ćete biti uspešniji od proseka i da će vam neki zadaci biti relativno jednostavni.

Možete se potpisati imenom i prezimenom, ali možete koristiti i šifru. Važno je da zapamtite šifru jer ćete raditi još nekoliko kratkih testova koje treba da povežemo.

Treba da odgovarate što brže i što tačnije. Odgovori koje date za duže od 10 sekundi neće ući u Vaš konačni skor. Na tastaturi su markirani tasteri za odgovaranje. Možete se pripremiti i početi kad Vam bude odgovaralo. Ukoliko imate bilo kakvo pitanje, molimo Vas da se obratite eksperimentatoru.

Prvi ekran koji su ispitanici videli nakon upisivanja imena ili šifre sadržao je uputstvo:

Test koji je pred vama sastoji se od tri bloka zadataka.

Vi treba da od ponuđenih odgovora odaberete tačan pritiskom na taster $a, b, c, d$ ili $e$. Kada jednom date odgovor, prelazite na sledeći zadatak.

Ukoliko vam za odgovor bude potrebno više od 10 sekundi, taj odgovor neće ući u vaš konačni skor.

Prvi blok u ovom testu bio je subtest numeričnosti, koji je sadržao 9 aritmetičkih zadataka sa ponuđenim odgovorima (Slika 2).

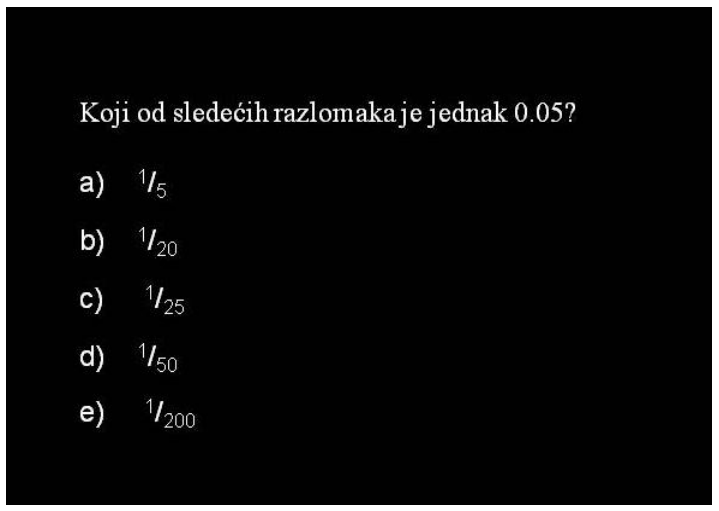

Slika 2. Primer zadatka iz subtesta Numeričnosti, izgled ekrana.

Drugi blok se sastojao 12 zadataka u kojima se od ispitanika zahtevalo da nastavi numerički niz ili proceni šta od navedenog najbolje simbolizuje skup reči (deo zadataka preuzet je magistarskog rada Bodroža, 2009) (Slika3). 
a) 8

b) 9

c) 11

d) 13

Slika 3. Primer zadatka iz subtesta Nizovi, izgled ekrana.

Treći blok se sastojao od 9 zadataka u kojima su ispitanici nastavljali figuralni niz birajući simbol koji nedostaje (Slika 4).

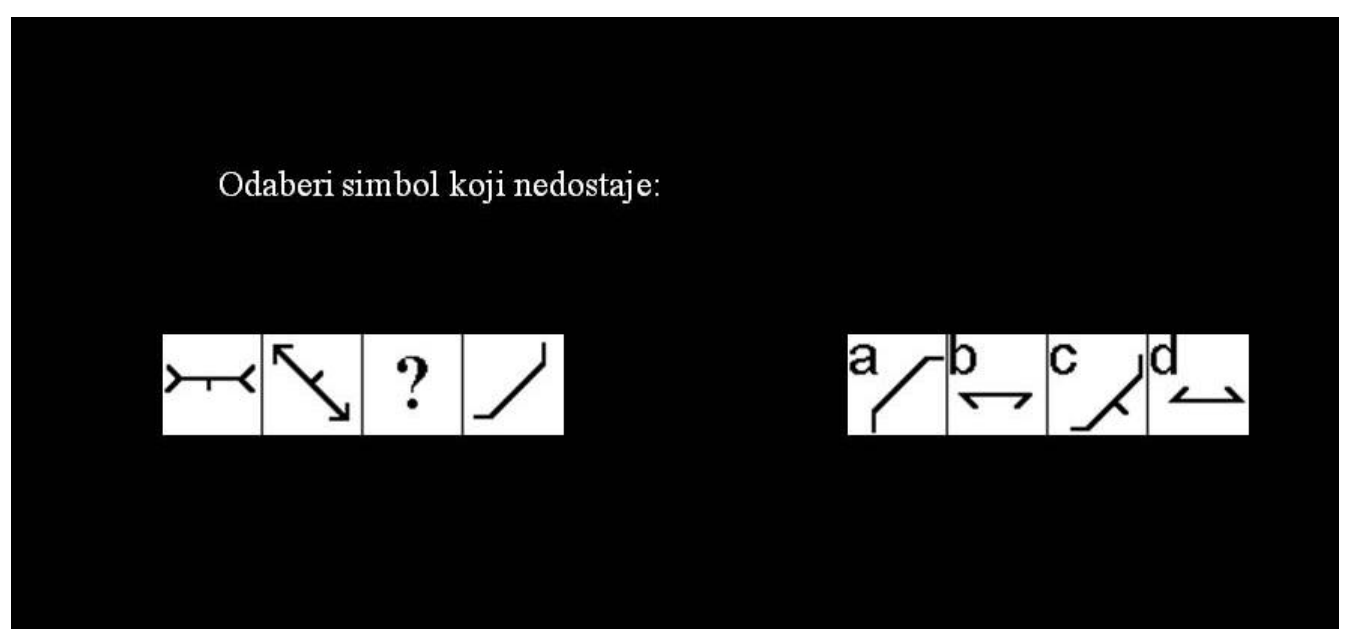

Slika 4. Primer zadatka iz subtesta Figuralno, izgled ekrana.

Na kraju svakog bloka i na kraju čitavog testa, ispitanici su dobijali povratnu informaciju o svom uspehu izraženu u percentilima i o prosečnom vremenu reakcije. Ovi ekrani su se pojavljivali nakon 5 sekundi tokom kojih je navodno kalkulisan skor, a njihov izgled je bio takav da uveri ispitanike da je u pitanju individualizovani fidbek (Slika 5). 


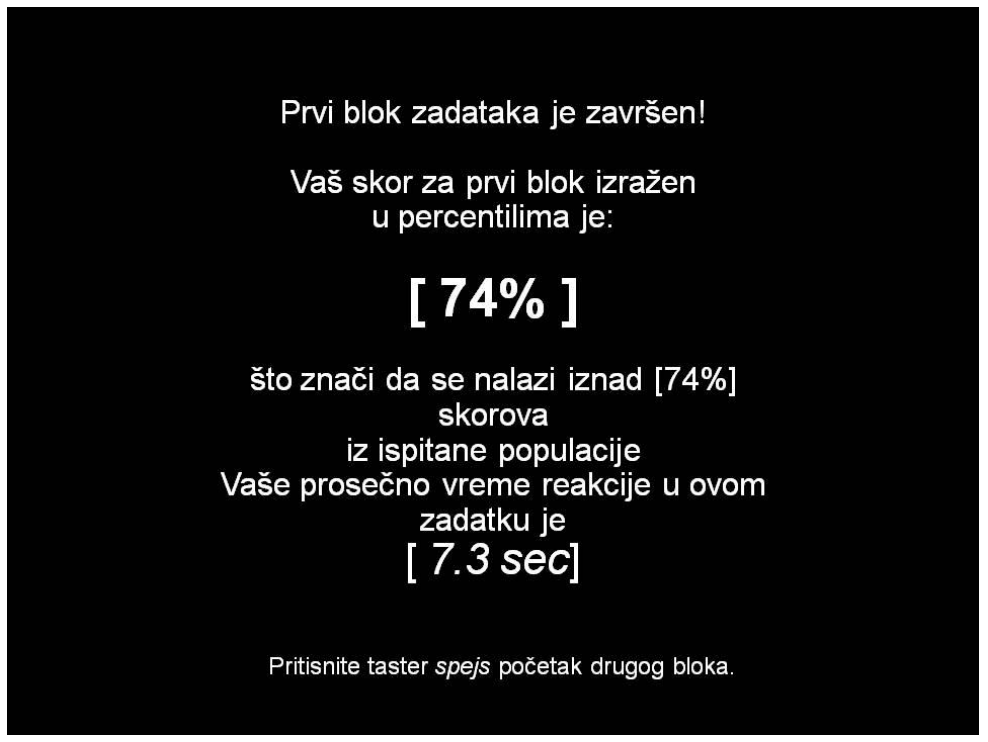

Slika 5. Primer povratne informacije o postignuću na testu, izgled ekrana.

Povratna informacija izražena je u percentilima, kako bi delovala validnije: istraživačka pretpostavka (Gilovich, Kerr \& Husted-Medvec, 1993; Plaks \& Stecher, 2007) bila je da ispitanici neće moći da dovedu u pitanje svoj položaj na nekoj zamišljenoj distribuciji skorova upravo zbog toga što su im nepoznata postignuća drugih iz grupe. Raspon percentila bio je 70 do 78, kako bi bili u istoj kategoriji po uspehu, a ipak delovali kao individualizovan fidbek. Iako su ispitanici imali neograničeno vreme za odgovaranje, u početnom uputstvu rečeno im je da odgovori dati za duže od 10 sekundi neće ući u konačan skor. Ovo zbog toga da bi informacija o vremenu reakcije delovala verodostojno, a i da bi se ispitanici trudili da završe test u nekom ograničenom vremenu. Raspon prosečne brzine bio je 6.8 do 8.2 sekunde. Nijedan ispitanik nije izrazio sumnju u dobijenu povratnu informaciju.

Test vizuelne percepcije počinjao je sličnim usmenim uputstvom:

U okviru ovog istraživanja testiramo kraću verziju testa vizuelne percepcije na opštoj populaciji. Na kraju svakog bloka zadataka i na kraju celog testa dobićete povratnu informaciju o uspehu.

$\mathrm{Na}$ kraju svakog bloka zadataka i na kraju celog testa dobićete povratnu informaciju o uspehu. Ona neće biti izrazena kao skor ili procenat tačnih zadataka, već kao Vaš položaj u ispitanoj populaciji (percentil). Dakle, ispis na ekranu ce vam reći na kom percentilu se nalazi Vaš rezultat, odnosno od koliko procenata populacije ste uspešnije uradili test.

Možete se potpisati imenom i prezimenom, ali možete koristiti i šifru. Važno je da zapamtite šifru jer ćete raditi još nekoliko kratkih testova koje treba da povežemo. 
Treba da odgovarate što brže i što tačnije. Odgovori koje date za duže od 10 sekundi neće ući u Vaš konačni skor. Na tastaturi su markirani tasteri za odgovaranje. Možete se pripremiti i početi kad Vam bude odgovaralo. Ukoliko imate bilo kakvo pitanje, molimo Vas da se obratite eksperimentatoru.

Ovaj test se takođe sastojao iz tri bloka: u prvom je zadatak ispitanika bio da procene koja od ponuđenih duži po dužini odgovara onoj sa leve strane ekrana (Slika 6).

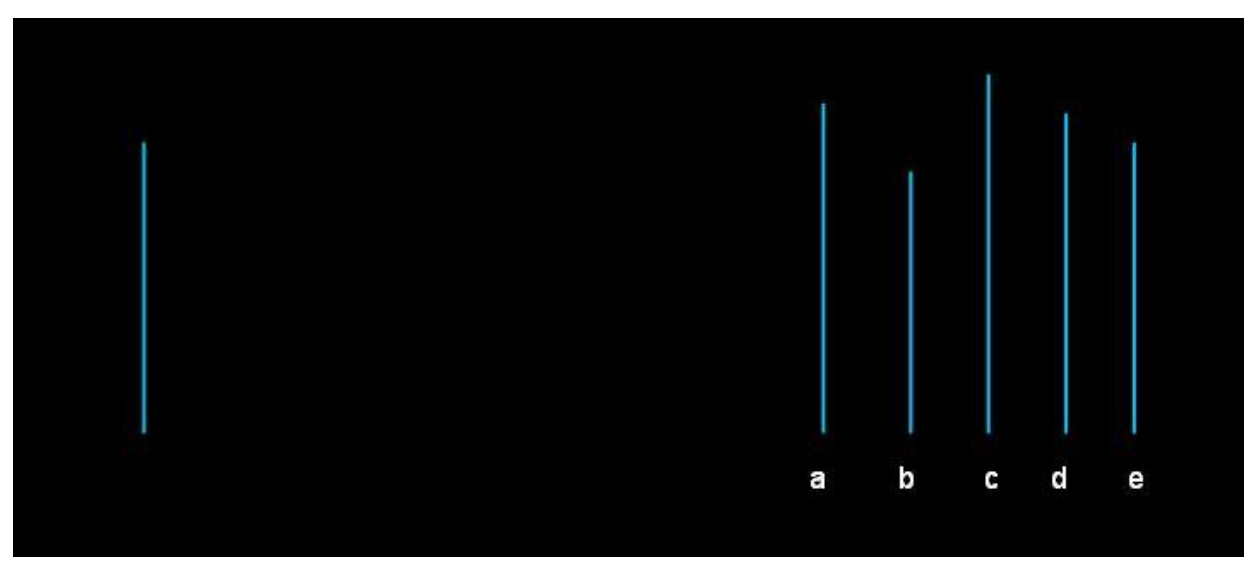

Slika 6. Primer zadatka iz subtesta Procena dužine, izgled ekrana.

U drugom bloku, ispitanici su procenjivali koja od ponuđenih boja odgovara boji figure sa desne strane ekrana (Slika 7).

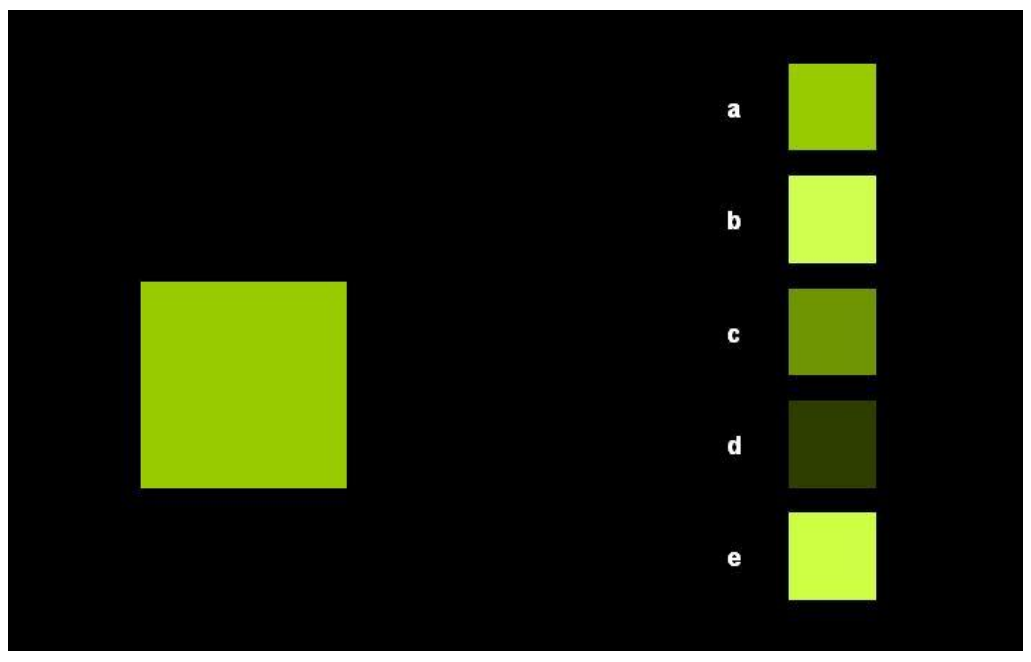

Slika 7. Primer zadatka iz subtesta Uparivanje boja, izgled ekrana.

U trećem bloku, ispitanici su nakon kratke ekspozicije (700 ms) procenjivali koliko je tačaka bilo u skupu (Slika 8). 

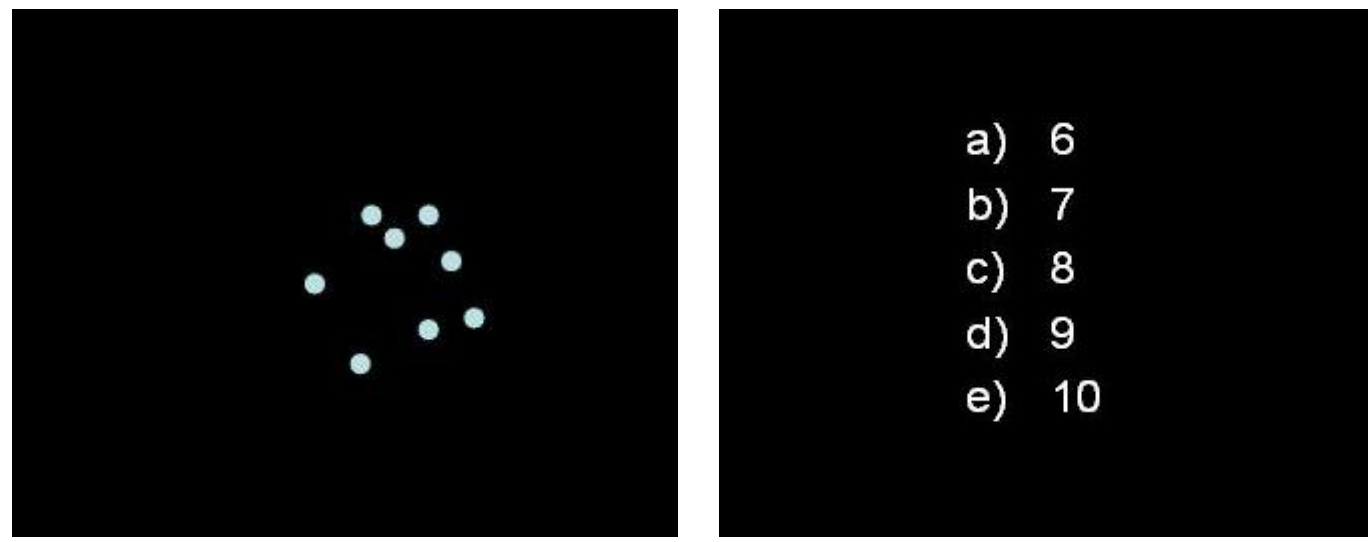

Slika 8. Primer zadatka iz subtesta Procena broja tačaka, izgled ekrana.

Informacija o rezultatu saopštavana im je na isti način kao i u testu sposobnosti. Sadržaj testa i fidbek u stvari su zavisili od verzije ogleda koja je bila instalirana na određenom računaru, a ispitanici su slučajno raspoređivani da rade test na nekom od računara.

Nakon elektronskog popunjavanja testa, ispitanicima smo se obraćali sledećim uputstvom:

Sada vas molimo da popunite ovaj kratak upitnik. Na označenom mestu upišite istu šifru koju ste koristili u elektronskom testiranju. Kada zavrsite sa upitnikom, okrenite drugu stranu. Molimo vas da ostavite svoje testove ispod računara na kojima ste popunjavali testove.

Po završetku ove faze, ispitanike smo ili direktno retestirali ili najavljivali retest za nedelju dana. Ispitanici su debrifirani u grupama od pet do dvadeset. U slucaju naknadnog retesta, upozoravali smo ih da je veoma vazno da do tada ne razgovaraju o ogledu, jer bi to moglo da ugrozi validnost procedure, a ukoliko se ogled kompromituje i njihovo učešće neće biti registrovano.

\section{Zavisna varijabla}

Zavisna varijabla (stepen izraženosti greške preterivanja) izražavana je kao razlika između skora o kome ispitanici izveštavaju i skora koji im je saopšten na sva tri subtesta i testu u celini $^{19}$.

\footnotetext{
${ }^{19}$ Izračunata po istom principu kao u prvom ogledu.
} 


\section{Rezultati}

\section{Koliko ispitanika greši?}

$\mathrm{Na}$ isti način na koji i u prethodnom ogledu, formirali smo tri grupe subjekata u odnosu na to da li i u kom pravcu su grešili u izveštavanju o ukupnom skoru na testu. Odlučili smo se da ukupni skor bude glavna zavisna varijabla, iako su ispitanici davali izveštaje i o skorovima na tri odvojena bloka zadataka, zato što smo pretpostavili da je ukupan skor najvažnija povratna informacija o ukupnoj sposobnosti koju je test trebalo da meri, pa samim tim i informacija za koju je najvažnije utvrditi eventualna memorijska odstupanja i pravilnosti u tim odstupanjima.

Preko 70\% ispitanika saopštava da su postigli veći ukupni skor na testu (izraženom u percentilima), nego što im je inicijalno rečeno da su postigli. (Tabela 9)

Tabela 9

Odnos potcenjivača, tačnih izveštača i precenjivača u izveštavanju o ukupnom skoru na testu

\begin{tabular}{lcc}
\hline & \multicolumn{2}{c}{ Ukupan skor na testu } \\
\cline { 2 - 3 } & Frekvencije & Procenat \\
\cline { 2 - 3 } Potcenjivači & 6 & 4.8 \\
Tačni izveštači & 32 & 23.4 \\
Precenjivači & 97 & 71.8 \\
\hline
\end{tabular}

Uticaj javnosti situacije. Proporcionalna zastupljenost sve tri kategorije izveštača zavisi od situacije u kojoj se izveštava $\left(\chi^{2}(2)=5.68, p=.058\right)$. Iako je u obe grupe znatno više precenjivača, ovaj odnos je izraženiji među onima koji usmeno saopštavaju svoj rezultat, nego među onima koji to čine pismeno (Grafikon 17). Ova pravilnost je očekivana, s obzirom na pretpostavku da je u situaciji usmenog saopštavanja u većoj meri aktiviran motiv za samopredstavljanjem. 


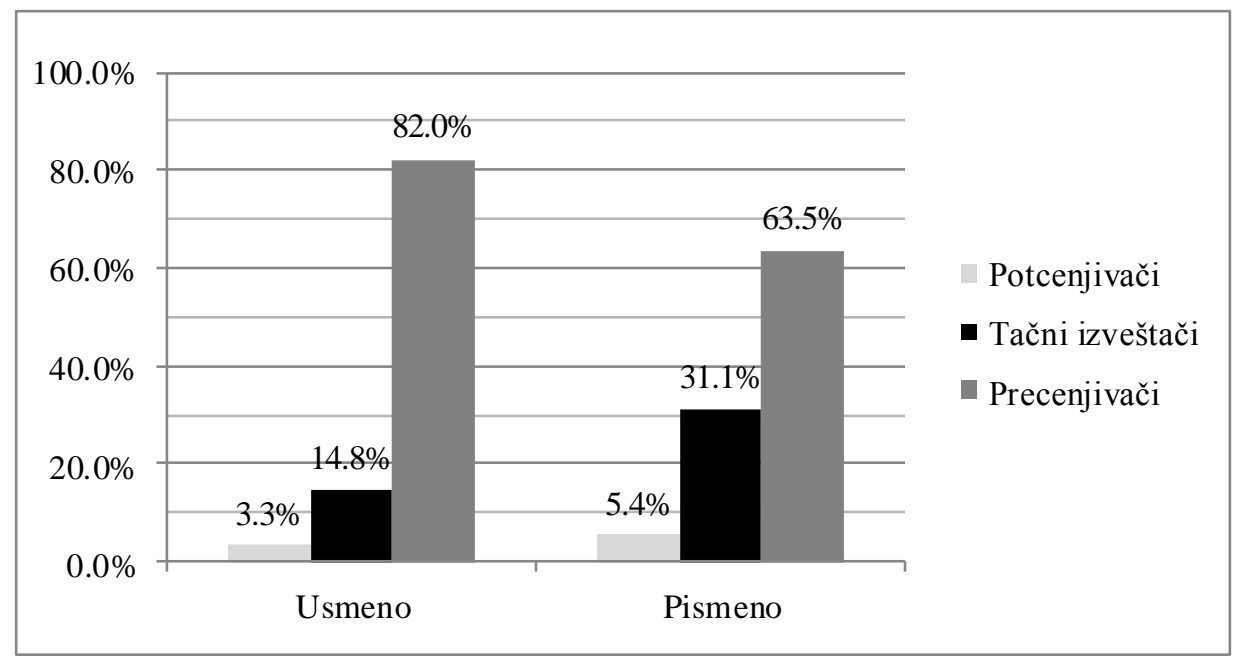

Grafikon 17. Zastupljenost potcenjivača, tačnih izveštača i precenjivača u izveštavanju o ukupnom skoru na testu u zavisnosti od situacije u kojoj se izveštava (usmeno ili pismeno).

Uticaj memorijske dostupnosti. U skladu sa očekivanjima, više je ispitanika saopštavalo uvećane ukupne skorove na testu kada su bili retestirani nakon nedelju i više dana, nego kada su bili retestirani neposredno nakon eksperimentalnog zadatka $\left(\chi^{2}(2)=5.79, p=.055\right)$. U obe grupe je ponovo bilo značajno više precenjivača u poređenju sa druge dve kategorije, ali među neposredno retestiranim bilo znatno više tačnih izveštača nego među naknadno retestiranim.

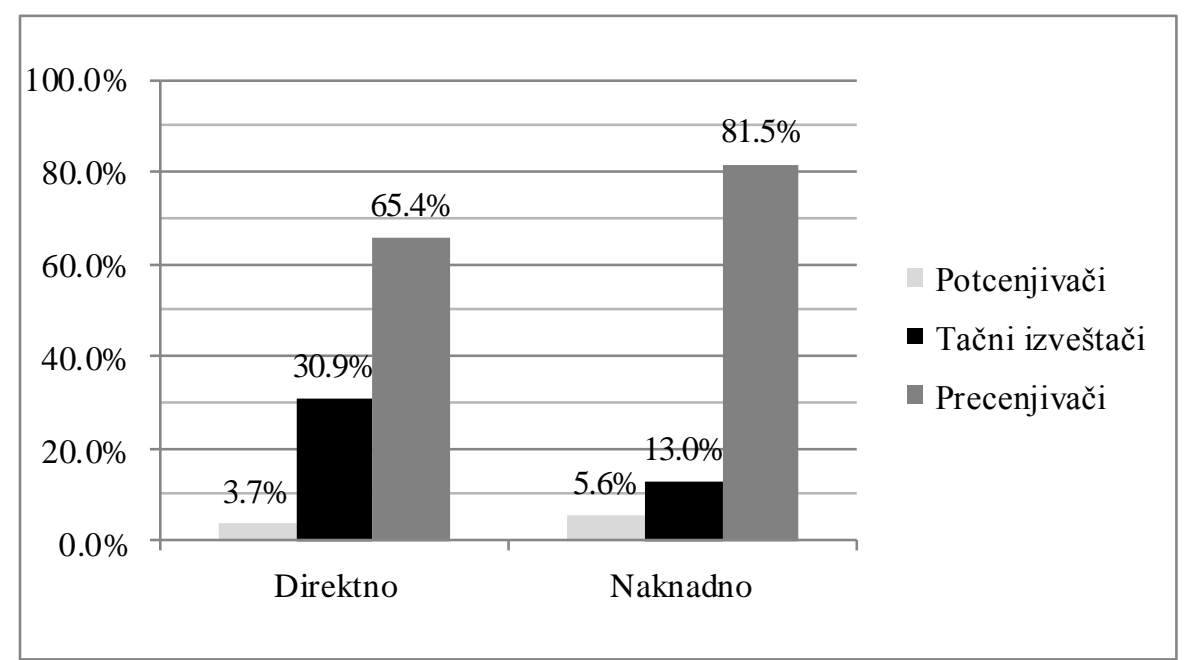

Grafikon 18. Zastupljenost potcenjivača, tačnih izveštača i precenjivača u izveštavanju o ukupnom skoru na testu u zavisnosti od memorijske dostupnosti događaja (da li se izveštava direktno nakon ogleda ili naknadno). 
Grafikon 19. Zastupljenost potcenjivača, tačnih izveštača i precenjivača u izveštavanju o ukupnom skoru na testu u zavisnosti od značaja merene sposobnosti ( test vizuelne percepcije ili test opšte intelektualne sposobnosti).

Uticaj uključenosti (značaja merene sposobnosti). Odnos među tri kategorije izveštača nije se, međutim, razlikovao u zavisnosti od toga da li su radili test koji im je bio predstavljen kao test opšte intelektualne sposobnosti, ili test vizuelne percepcije $\left(\chi^{2}(2)=1.204, p=.55\right)$ (Grafikon 19).

\section{Koliko ispitanici greše? Intenzitet greške preterivanja}

Nakon što smo utvrdili broj ispitanika koji precenjuju sopstvena postignuća trebalo je ispitati da li se stepen odstupanja njihovog izveštaja od realnog skora zaista može nazvati preterivanjem, zbog toga smo proverili da li se greška preterivanja značajno razlikuje od nule i to u sve četiri registrovane situacije: izveštavanje o postignuću na blokovima u okviru testa, i izveštavanje o ukupnom skoru na testu. T test za iste uzorke utvrdio je da se u sve četiri situacije greši u očekivanom smeru (izveštava o većem skoru), i da je greška u sve četiri situacije značajno različita od nule (Tabela 10). 
Tabela 10

Značajnost odstupanja greške preterivanja od nule u izveštavanju o tri bloka u testu $i$ ukupnom skoru na testu

\begin{tabular}{lcccc}
\hline & $\mathrm{t}$ & $\mathrm{df}$ & $\begin{array}{c}\text { Nivo } \\
\text { značajnosti }\end{array}$ & $\begin{array}{c}\text { Prosečna } \\
\text { razlika }\end{array}$ \\
\hline $\begin{array}{l}\text { Razlika saopštenog i tačnog skora na prvom } \\
\text { delu testa }\end{array}$ & 4.627 & 134 & .000 & .69 \\
$\begin{array}{l}\text { Razlika saopštenog i tačnog skora na drugom } \\
\text { delu testa }\end{array}$ & 4.604 & 134 & .000 & 1.08 \\
$\begin{array}{l}\text { Razlika saopštenog i tačnog skora na trecem } \\
\text { delu testa }\end{array}$ & 2.877 & 134 & .005 & .68 \\
$\begin{array}{l}\text { Razlika saopštenog i tačnog ukupnog skora na } \\
\text { testu }\end{array}$ & 8.796 & 134 & .000 & 1.34 \\
\hline
\end{tabular}

Da bismo analizu i prikaz podataka učinili sistematičnijim, konstruisali smo i jedinstven indeks preterivanja - zbir odstupanja u izveštavanju u sve četiri situacije, i dalje analize uradili koristeći dve osnovne zavisne varijable: tako konstruisan indeks preterivanja i grešku preterivanja u izveštavanju o ukupnom skoru na testu.

Intenzitet greške u zavisnosti od javnosti situacije retestiranja. Analiza varijanse na ponovljenim merama pokazala je da se zbir odstupanja za sve testove kao i odstupanje u izveštaju o ukupnom skoru značajno razlikuju u zavisnosti od toga da li se izveštava u privatnoj ili javnoj situaciji. U skladu sa očekivanjima, greške su bile izraženije u usmenom intervjuu nego u pismenom upitničkom retestiranju $(F(1,135)=5.563, p=.02 ; F(1$, $135)=2.91, p=.091)^{20}(\operatorname{Graf} 20)$.

\footnotetext{
${ }^{20}$ Prvi efekat značajnosti odnosi se na zbir odstupanja za sve oglede a drugi na odstupanje u izveštavanju o ukupnom skoru
} 


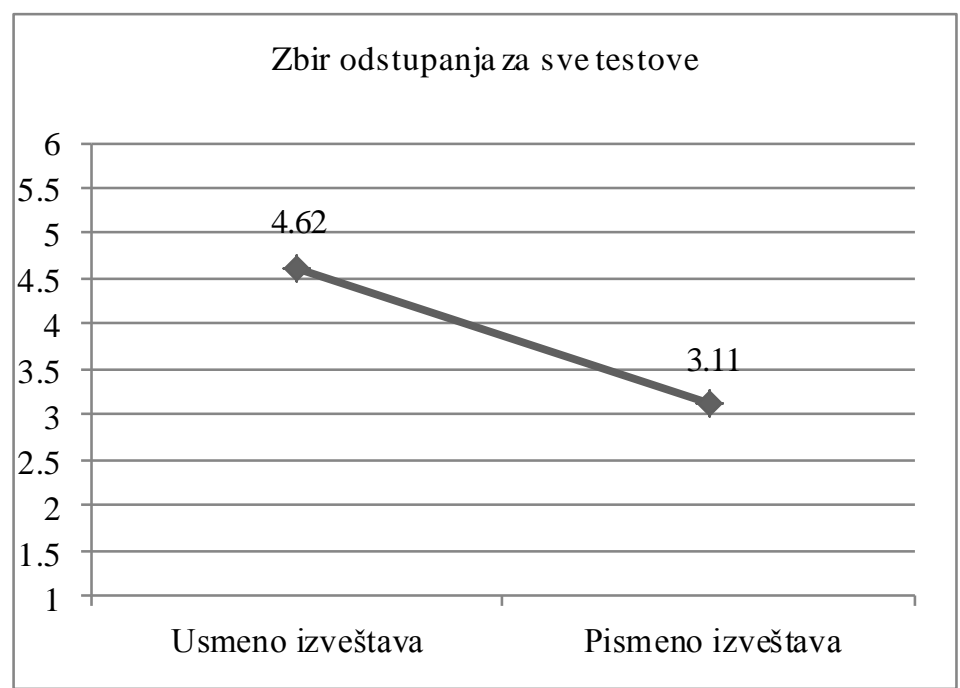

Grafikon 20. Zbirno odstupanje u izveštavanju u zavisnosti od javnosti situacije.

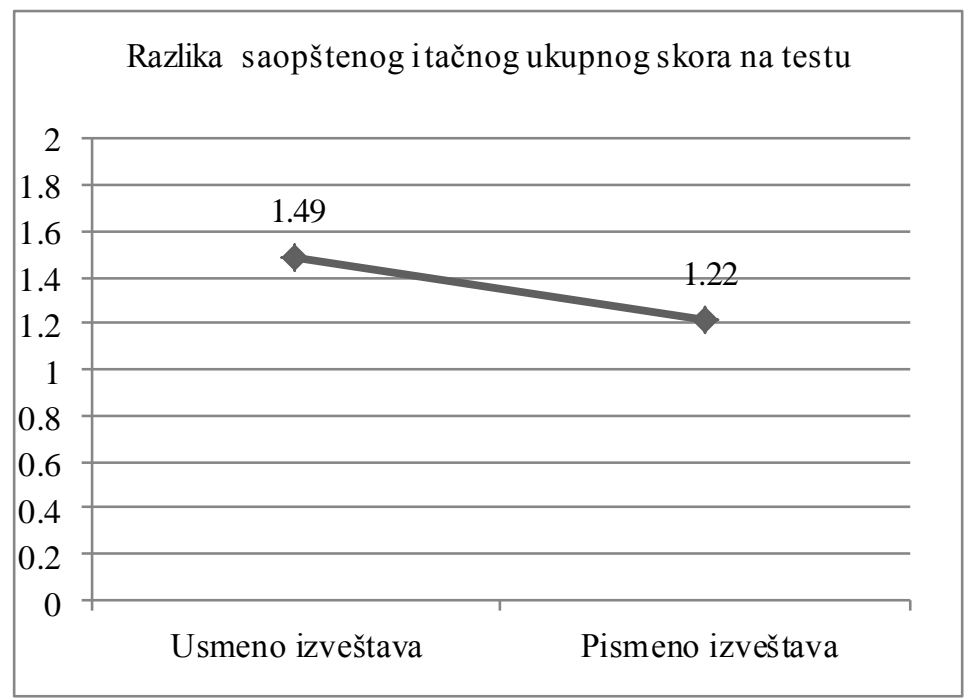

Grafikon 21. Odstupanje u izveštavanju o ukupnom skoru u zavisnosti od javnosti situacije.

Uticaj memorijske dostupnosti. Dalje, analizirali smo da li se intenzitet greške menja u zavisnosti od memorijske dostupnosti događaja: kao što je i očekivano, greška je bila značajno veća kada su ispitanici retestirani sa nedelju i više dana razmaka u odnosu na primarno testiranje; ovo se potvrđuje i u slučaju zbirnog odstupanja $(F(1,135)=9.60, p=.002$, i odstupanja u ukupnom skoru $(F(1,135)=14.284, p=.000)$.

Uticaj uključenosti (značaja merene sposobnosti). Na kraju, analizirali smo efekat faktora "značaj merene sposobnosti". Intenzitet zbirne greške i greške u izveštavanju u ukupnom skoru nije se značajno razlikovao u zavisnosti od toga da li je u pitanju bio test inteligencije 
ili test vizuelnih sposobnosti, iako su razlike bile u očekivanom smeru: više se precenjivalo u izveštavanju o značajnijoj sposobnosti (Grafikon 22).

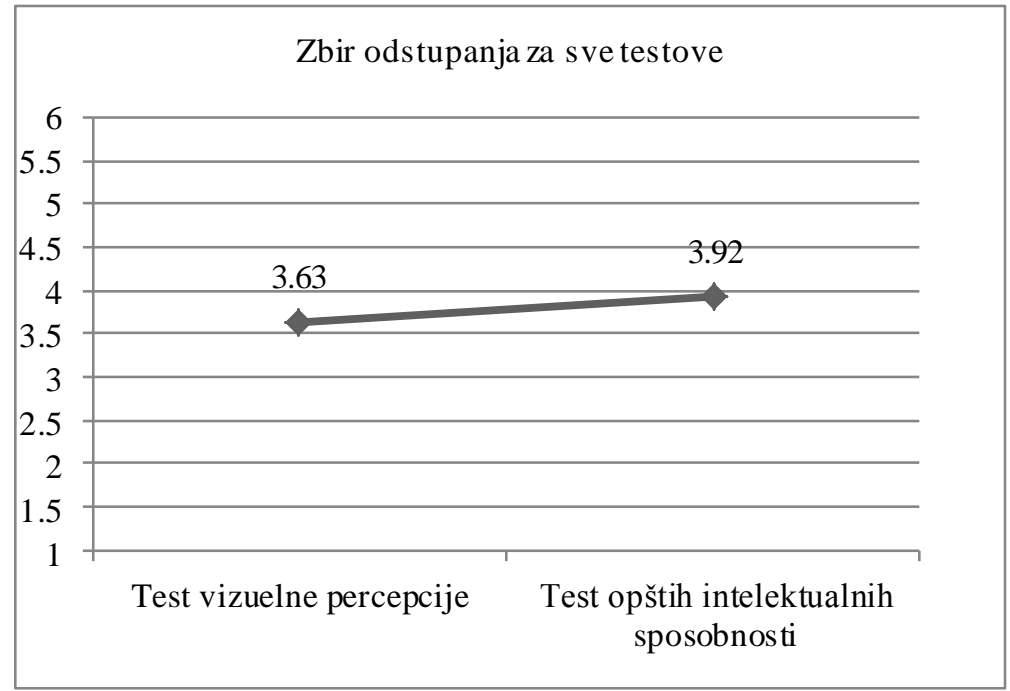

Grafikon 22. Zbirno odstupanje u izveštavanju u zavisnosti od značaja merene sposobnosti (uključenosti).

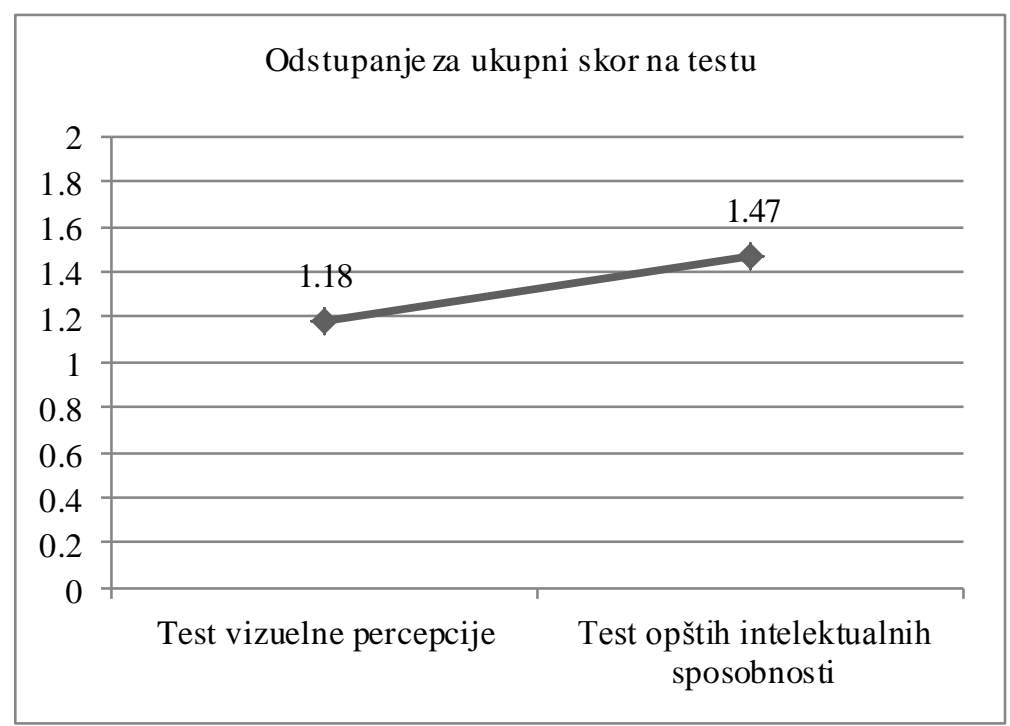

Grafikon 23. Odstupanje u izveštavanju o ukupnom skoru u zavisnosti od značaja merene sposobnosti (uključenosti).

Nije zabeležena nijedna značajna dvostruka ni značajna trostruka interakcija među faktorima. 


\section{Apsolutna greška u izveštavanju o postignuću na testovima}

Kao i u prethodnom ogledu, zanimalo nas je da li postoji razlika u tačnosti izveštavanja, nezavisno od predznaka greške, kada se posmatraju iste nezavisne varijable.

Uticaj javnosti situacije, memorijske dostupnosti $i$ uključenosti. Apsolutna greška u izveštavanju bila je značajno veća kada je situacija retestiranja bila javna, nego privatna ( $F$ $(1,135)=5.987, p=.016 ; F(1,135)=3.119, p=.080)$; kada je retest bio naknadan a ne direktan $(F(1,135)=22.244, p=.000 ; F(1,135)=21.243, p=.000)$ i veća, ali marginalno značajno kada je u pitanju bio test intelektualnih sposobnosti nasuprot vizuelno-perceptivnim ( $F$ (1, $135)=2.919, p=.090 ; F(1,135)=2.926, p=.090)$.

\section{Povezanost sklonosti ka grešci preterivanja sa indikatorima psihološke adaptiranosti}

Zbirno i pojedinačno odstupanje u izveštavanju o skorovima sa testa značajno su povezani sa drugim indeksom pristrasnosti sećanja (spontano evociranim pozitivnim autobiografskim sećanjima). Od indikatora psihološke adaptiranosti, značajno su povezani samo sa optimističnim odnosom prema budućnosti.

Tabela 11

Matrica korelacija: povezanost indikatora memorijskih pristrasnosti u izveštavanju o uspehu na testovima sposobnosti sa indikatorima psihološke adaptiranosti

\begin{tabular}{|c|c|c|c|c|c|c|}
\hline & $\begin{array}{c}\text { Skor na } \\
\text { skali } \\
\text { Akademskih } \\
\text { ambicija }\end{array}$ & $\begin{array}{c}\text { Skor na } \\
\text { Rozenbergovoj } \\
\text { skali } \\
\text { samopoštovanja }\end{array}$ & $\begin{array}{c}\text { Skor na } \\
\text { skali LOT } \\
\text { (životnog } \\
\text { optimizma) }\end{array}$ & $\begin{array}{l}\text { Skor na skali } \\
\text { dominantnog } \\
\text { raspoloženja }\end{array}$ & $\begin{array}{l}\text { Broj pozitivnih/ } \\
\text { ukupan broj } \\
\text { spontano } \\
\text { navedenih } \\
\text { sećanja }\end{array}$ & $\begin{array}{c}\text { Zbir odstupanja } \\
\text { za sve testove }\end{array}$ \\
\hline $\begin{array}{l}\text { Odstupanje u } \\
\text { izveštaju o } \\
\text { ukupnom skoru }\end{array}$ & .04 & .04 & $.20(*)$ & .01 & $.58(* *)$ & $.88(* *)$ \\
\hline $\begin{array}{l}\text { Zbir odstupanja } \\
\text { za sve testove }\end{array}$ & .11 & .03 & $.16\left(^{-}\right)$ & .03 & $.23(* *)$ & \\
\hline
\end{tabular}




\section{Predviđanje raspona greške preterivanja}

Kada smo u okviru multiple regresione analize kao kriterijum uzeli grešku preterivanja u izveštavanju o ukupnom skoru na testu, pokazalo se da prediktorski skup objašnjava 19\% varijanse kriterijuma $\left(R^{2}=.19, F(7,135)=3.57, p=.001\right)$. U okviru prediktora, kao značajni su se pokazali memorijska dostupnost događaja $(\beta=.32, p=.000)$, javnost situacije odnosno motiv za samopredstavljanjem $(\beta=.18, p=.032)$, i indeks pozitivnosti autobiografskih sećanja, kao indikator sklonosti kao memorijskim pristrasnostima $(\beta=.17, p=.05)$ (Tabela 12).

Tabela 12

Regresiona analiza sa greškom preterivanja kao zavisnom varijablom

\begin{tabular}{|c|c|c|c|c|c|}
\hline & $\begin{array}{r}\text { Nestanc } \\
\text { koe }\end{array}$ & $\begin{array}{l}\text { izovani } \\
\text { enti }\end{array}$ & $\begin{array}{c}\text { Standardizovani } \\
\text { koeficijenti }\end{array}$ & & \\
\hline & B & SE (B) & $B$ & $\mathrm{t}$ & $\mathrm{p}$ \\
\hline & -2.00 & 1.56 & & -1.28 & .203 \\
\hline $\begin{array}{l}\text { Skor na skali LOT } \\
\text { (životnog optimizma) }\end{array}$ & .09 & .05 & .18 & 1.94 & .055 \\
\hline $\begin{array}{l}\text { Broj pozitivnih/ukupan broj } \\
\text { spontano navedenih sećanja }\end{array}$ & 1.40 & .71 & .17 & 1.98 & .050 \\
\hline $\begin{array}{l}\text { Skor na skali dominantnog } \\
\text { raspoloženja }\end{array}$ & .02 & .02 & .12 & 1.36 & .177 \\
\hline $\begin{array}{l}\text { Skor na Rozenbergovoj } \\
\text { skali samopoštovanja }\end{array}$ & -.02 & .03 & -.06 & -.64 & .525 \\
\hline $\begin{array}{l}\text { Skor na skali Akademskih } \\
\text { ambicija }\end{array}$ & -.03 & .07 & -.04 & -.48 & .630 \\
\hline $\begin{array}{l}\text { Usmeni ili pismeni retest } \\
\text { (samopredstavljanje) }\end{array}$ & -.64 & .29 & -.18 & -2.16 & .032 \\
\hline $\begin{array}{l}\text { Direktni ili naknadni retest } \\
\text { (memorijska dostupnost } \\
\text { događaja) }\end{array}$ & 1.15 & .30 & .32 & 3.78 & .000 \\
\hline
\end{tabular}




\section{Diskusija}

U prethodnom ogledu ispitanici su izveštavali o svojim postignućima koja bi trebalo da budu sistematski ugrađena u sliku o sebi i koja su imala realne životne posledice (mogućnost upisa na fakultet). Uprkos ekološkoj validnosti ovakvih ogleda, njihov dizajn podrazumevao je izvesna ograničenja: (a) glavne nezavisne varijable su u ovom slučaju bile samo registrovane, i nisu bile podložne manipulaciji; (b) postojala je unapred definisana restrikcija ranga (bili su nam dostupni samo upisani studenti, dakle oni koji su sa manjim ili većim uspehom položili prijemni ispit i bili konačno primljeni na fakultet). Zbog toga smo osmislili oglede u kojima smo manipulisali nezavisnim promenljivim da bismo izmerili efekte ovih manipulacija na memorijske distorzije i da bismo stekli bolji uvid u motive koji im leže u osnovi. Pored toga, eksperimentalni nacrt u kome ispitanici rade pod istim uslovima i u kome je moguće registrovati i njihove neposredne reakcije na postignuće pružao je mogućnost bolje kontrole uslova ispitivanja.

Kako je u prvom ogledu nedvosmisleno utvrđeno da su ljudi skloni grešci preterivanja ukoliko izveštavaju o značajnim životnim događajima, drugi je ogled dizajniran tako da proveri da li se ova sklonost javlja i kada su u pitanju manje značajna postignuća koja nemaju jasno definisane posledice i mere periferne osobine.

Tako smo, pored memorijske dostupnosti događaja i javnosti situacije retestiranja, varirali sadržaj samog testa sa idejom da će postignuće na testu koji meri sposobnost značajniju za sliku o sebi biti u većoj meri pozitivno preinačeno nego postignuće na testu koji meri relativno nevažnu sposobnost. Rezultati su ubedljivo potvrdili efekat prva dva faktora: u naknadnom retestu ispitanici su bili manje tačni i više pozitivno pristrasni nego u direktnom retestu, i u javnoj situaciji bili su manje tačni i više pozitivno pristrasni nego u privatnoj ${ }^{21}$. Iako su ispitanici bili nešto više pristrasni i manje tačni u izveštavanju o značajnijoj sposobnosti, ova razlika nije bila značajna, odnosno bila je marginalno značajna. Jedini ogled koji nam je poznat $u$ kome je na sličan način manipulisano značajem merene sposobnosti (Leszczynska, 2011) takođe nije uspeo da provocira očekivanu razliku: iako je registrovana greška preterivanja, ona nije bila veća u testu značajnije sposobnosti (u toj studiji, samo je sadržaj instrukcije upućivao na značaj merene osobine). Iz ove perspektive čini se verovatnim da test situacija nije uspela da izazove dovoljno velike razlike u uključenosti, odnosno da je bila visoko involvirajuća za obe grupe učesnika. Tome je

\footnotetext{
${ }^{21}$ Za kasniju diskusiju je od značaja napomenuti da je pozitivna pristrasnost ipak registrovana i u privatnoj situaciji, kada su ispitanici retestirani pod šifrovanim imenom.
} 
doprinelo nekoliko metodoloških odluka: pre svega, obe grupe su bile testirane i dobijale direktan fidbek o određenoj svojoj sposobnosti. Bilo kakva evaluacija čiji je rezultat numerički izražena mera sposobnosti, izgleda da uključuje učesnike. Dalje, rezultat je bio izražen u percentilima, i to u odnosu na referentnu grupu, što je kod ispitanika moglo da provocira kompetitivnost i tendenciju ka socijalnom poređenju. U nekom od sledećih ogleda trebalo bi još više kontrastirati merene osobine, i razliku osnažiti uputstvom u kome bi se naglasilo na primer, da jedna osobina predviđa uspeh na studijama i visinu zarade, a druga nije prediktivna ili je prediktivna za neke irelevantne životne događaje. U ovom procesu "udaljavanja" osobina po njihovom značaju za subjekte, mora se voditi računa o tome da i nisko involvirajuća osobina još uvek mora da deluje kao značajna, za koju je smisleno sprovoditi testiranja i porediti učinak ispitanika. Ovo ograničenje je važno kako bi i ispitanici u nisko involviranoj grupi još uvek ipak bili motivisani da urade test što bolje mogu. Alternativno objašnjenje izostanka razlika bilo bi da je sklonost ka grešci preterivanja nezavisna od značaja merene osobine, odnosno da se podjednako javlja i za periferne i za centralne osobine. S obzirom da su razlike u očekivanom smeru ipak registrovane, i da nam je ponašanje ispitanika na samom testu ukazivalo da pridaju značaj povratnoj informaciji o sposobnosti, ovo se objašnjenje čini manje verovatnim.

Zanimljivo je što je procenat precenjivača identičan kao u prethodnom ogledu (71\%), a kao i u prethodnom ogledu, prosečna greška preterivanja nije velika: korekcija se u proseku kreće između jednog i dva percentila (ukupna greška na sva četiri merenja je 3.86). Većina ljudi dakle, pristrasno izveštava o svom postignuću, ali to čini tako da ostaje u domenu uverljivog (za sebe i za drugog).

Što se tiče veze greške preterivanja sa drugim merama odnosa prema sebi, dobijena je značajna pozitivna povezanost sa indeksom pozitivnosti autobiografskih sećanja, kao i u prethodnom ogledu, kao i sa ukupnim životnim optimizmom. U sličnom istraživanju (Wheeler, Brunson \& Walker, 2009) dovedena je u vezu sklonost ka ublažavanju negativnih afekata $\mathrm{u}$ procesu pamćenja (fading affect bias) sa orijentacijom u vremenu, merenom Inventarom vremenske perspektive (Zimbardo \& Boyd, 1999). Zimbardov instrument ispituje kako se ljudi odnose prema vremenu, da li su okupirani prošlošću, žive u sadašnjosti ili su orijentisani na budućnost. Grupa ljudi koja je pokazala najsnažniji efekat neutralizacije negativnih događaja bila je grupa orijentisana na budućnost. Ovi podaci svakako sugerišu da postoji smislena veza između načina na koji ljudi pamte i kako transformišu upamćene događaje i načina na koji opažaju sadašnjost i budućnost (Walker \& Skowronski, 2009). 


\section{Eksperiment 3}

\section{Dizajn}

Iako je u prvom ogledu postignuće ispitanika bilo dovoljnog raspona da se može govoriti o razlikama prema uspešnosti, ipak je raspon bio ograničen samo na studente koji su se zaista upisali na fakultet. Pored toga, uprkos činjenici da su, na primer bili gori od većine upisanih studenata, pojedinci na dnu liste su ipak mogli da taj događaj interpretiraju kao lični uspeh: imao je pozitivnu posledicu, a mnogi su prošli lošije od njih i našli se u drugoj grupi (neupisanih). Zbog toga smo u ovom ogledu, pored standardne manipulacije memorijskom dostupnošću i javnošću situacije, uključili i manipulaciju uspešnošću u situaciji testiranja.

I u ovom ogledu merila se greška preterivanja u laboratorijskom okruženju. Dizajn je bio 2 (skor se saopštavao javno ili privatno) x 2 (povratna informacija o uspehu ili neuspehu ) x 2 (memorijska dostupnost: jednoj grupi podaci su se uzimali neposredno nakon testiranja, a drugoj nedelju do dve nakon testiranja). Da bi se grupe razlikovale po motivaciji za samoprikazivanjem, jedna grupa je saopštavala svoj skor privatno, a druga javno (u individualnom intervjuu sa eksperimentatorom).

\section{Stimulus materijal}

Za potrebe ovog ogleda kreiran je poseban test, nazvan test Socijalno-kognitivnih sposobnosti. Ispitanicima je najavljen kao test socijalne kognicije, kojim se procenjuje osetljivost na socijalni kontekst, procene interpersonalnih odnosa i sposobnost snalaženja u socijalnoj sredini, sačinjen iz tri bloka pitanja.

\section{Procedura i učesnici}

U ovom ogledu učestvovalo je 167 studenata druge godine psihologije na Filozofskom fakultetu u Beogradu, slučajnim izborom raspoređenih u jednu od osam eksperimentalnih grupa (Tabela 4.3 u Prilogu 4).

Test koji su elektronski popunjavali se sastojao iz tri bloka pitanja: u prvom i trećem bloku bilo je po 10 zadataka u kojima se od ispitanika tražilo da procene koji su od statističkih nalaza kojima se opisuju određene društvene pojave tačni. Ovaj deo testa konstruisan je za potrebe istraživanja i uključivao je pitanja u vezi sa: prosečnim uzrastom u kome se stupa $u$ seksualne odnose, verovatnoćom razvoda u slučaju brakova različite veroispovesti, procentualnom zastupljenošću fobija u opštoj populaciji, brojem partnera u LGBT zajednici u 
poređenju sa heteroseksualnom itd. Ispitanicima je nakon svakog pitanja prikazano 3-5 ponuđenih odgovora, a njihov zadatak bio je da odaberu onaj za koji im se čini da je tačan (slika 9). U uputstvu im je naglašeno da se od njih ne očekuje da znaju tačne odgovore, već se upravo ispituje tačnost njihovih pretpostavki o socijalnom okruženju u kome žive.

Koliko adolescenata u Srbiji tvrdi da je ozbiljno razmišljalo o samoubistvu?

a. Manje od $10 \%$

b. $10 \%-20 \%$

c. $21-30 \%$

d. Preko $30 \%$

Slika 9. Primer zadatka iz subtestova 1 i 3 u testu Socijalno kognitivnih sposobnosti, izgled ekrana.

U drugom bloku ispitanicima je prikazan kratak opis 10 različitih parova i od njih je traženo da procene da li će njihove partnerske veze opstati duže od godinu dana ili ne. U opisima su navođene informacije o poreklu, sposobnostima, navikama i osobinama ličnosti mladića i devojaka u partnerskim vezama (slika 10). U uvodnom uputstvu ispitanicima je rečeno da se opisi baziraju na pravim studijama slučajeva, preuzetim iz psihoterapijske prakse. Za potrebe ovog istraživanja adaptirali smo Social-Cognitive Aptitude Test (SCAT, Crooker, Thompson \& McGraw, 1987 ) inicijalno konstruisan upravo za davanje lažne povratne informacije o uspehu odnosno neuspehu. Situacije u testu su prilagođene našoj kulturi i društvenoj sredini.

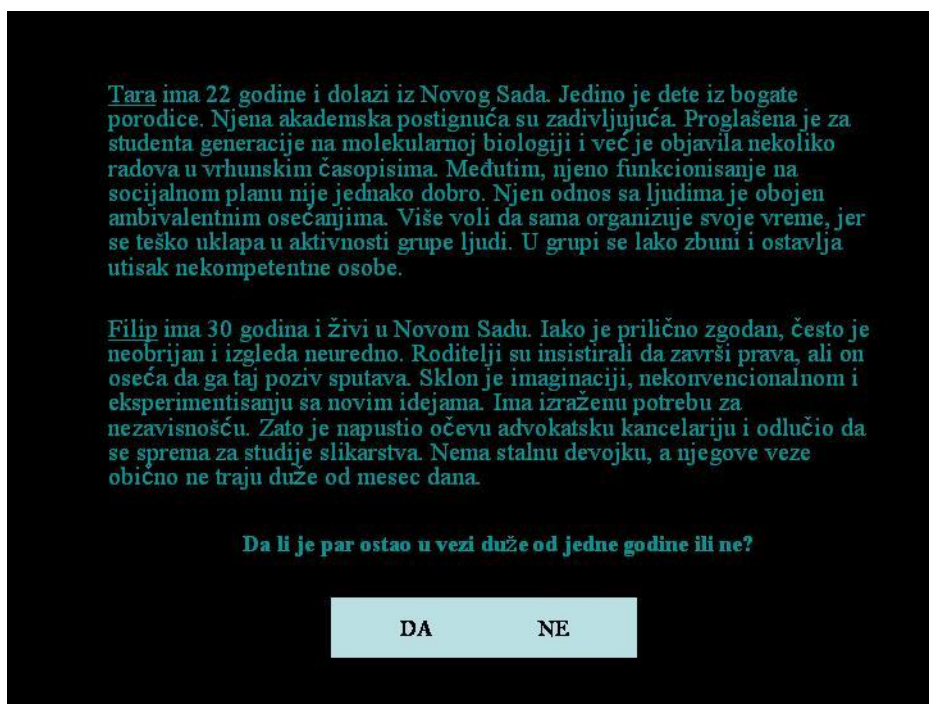

Slika 10. Primer zadatka iz subtesta 2 u testu Socijalno kognitivnih sposobnosti, izgled ekrana. 
U velikom broju ogleda u kojima je kod ispitanika provociran osećaj uspeha odnosno neuspeha istraživači su koristili testove sposobnosti. Najčešće je to serija anagrama, od kojih su neki veoma jednostavni a neki nerešivi, pa ispitanici u uspešnoj grupi dobijaju lakše a u neuspešnoj teže ili nerešive zadatke (Dunning, Leuenberger, \& Sherman, 1995; Dutton \& Brown, 1997; McGregor\&Eliot, 2005). Mi smo se opredelili za drugačiji sadržaj testa verujući da će biti zanimljiviji za ispitanike i da će zbog toga biti više motivisani, a pored toga da će biti značajan za njihovu sliku o sebi, s obzirom da im je predstavljen kao test koji meri sposobnosti značajne za profesije kojima će se verovatno baviti.

Nakon svakog bloka zadataka i testa u celini, ispitanicima je data informacija o percentilu na kome se nalazi njihov skor, pri čemu je u slučaju simulacije neuspeha, taj percentil varirao je od 35 do 48 a u slučaju simulacije uspeha od 80 do 95 . Pri određivanju opsega variranja skorova oslonili smo se na istraživanja koja pokazuju da je dovoljno da skor bude ispod proseka da bi se opazio kao neuspeh, a da se tek plasman u gornjih $20 \%$ ili čak $10 \%$ sigurno opaža kao uspeh (Dunning, Leuenberger \& Sherman, 1995; McGregor \& Elliot, 2005; Sagar \& Stoeber, 2009). Ispitanici su slučajnim izborom svrstani u "uspešnu" odnosno "neuspešnu" grupu (na računarima označenim parnim brojevima instalirane su verzije sa povratnom informacijom o uspehu, a na računarima označenim neparnim brojevima o neuspehu).

Nakon elektronskog popunjavanja testa, ispitanicima smo se obraćali istim uputstvom za popunjavanje upitnika kao u drugom ogledu.

Po završetku ove faze, ispitanike smo ili direktno retestirali ili najavljivali retest za nedelju dana. U slučaju naknadnog retesta naglašeno im je da ne komuniciraju između sebe da ne bi ugrozili validnost procedure i na isti način ih upozorili da im se bodovi za učešće u slučaju nevalidnog ogleda neće registrovati. Nakon što su svi retestirani, ispitanici su debrifirani u grupama od deset do četrdeset (jedno masovnije predavanje).

\section{Zavisna varijabla}

Zavisna varijabla (stepen izraženosti greške preterivanja) izražavana je kao razlika između skora o kome ispitanici izveštavaju i saopštenog skora na sva tri subtesta i testu u celini. 


\section{Rezultati}

\section{Koliko ispitanika greši ?}

I u ovom ogledu više od dve trećine ispitanika izvestilo je o višem ukupnom skoru na testu, a odnos među tri kategorije izveštača sličan je onom u drugom ogledu (Tabela 13).

Tabela 13

Odnos potcenjivača, tačnih izveštača i precenjivača u izveštavanju o ukupnom skoru na testu

\begin{tabular}{lcc}
\hline & \multicolumn{2}{c}{ Ukupan skor na testu } \\
\cline { 2 - 3 } & Frekvencije & Procenat \\
\cline { 2 - 3 } Potcenjivači & 3 & 1.9 \\
Tačni izveštači & 48 & 32.5 \\
Precenjivači & 106 & 65.6 \\
\hline
\end{tabular}

Iako je u situaciji usmenog izveštavanja bilo više precenjivača nego u situaciji pismenog, ova razlika nije dostigla statističku značajnost $\left(\chi^{2}(2)=2.604, p=.272\right)$.

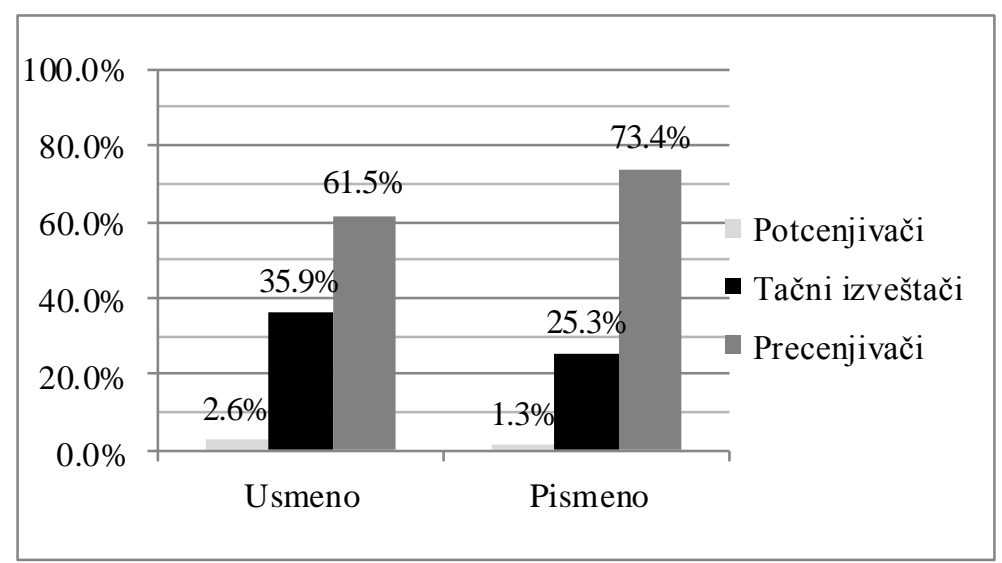

Grafikon 24. Zastupljenost potcenjivača, tačnih izveštača i precenjivača u izveštavanju o ukupnom skoru na testu u zavisnosti od situacije u kojoj se izveštava (usmeno ili pismeno). Kada je u pitanju memorijska dostupnost događaja, u grupi onih koji su naknadno izveštavali bilo je više precenjivača, a manje tačnih izveštača nego u grupi onih koji su izveštavali direktno $\left(\chi^{2}(2)=9.402, p=.009\right)$ (Grafikon 25). 


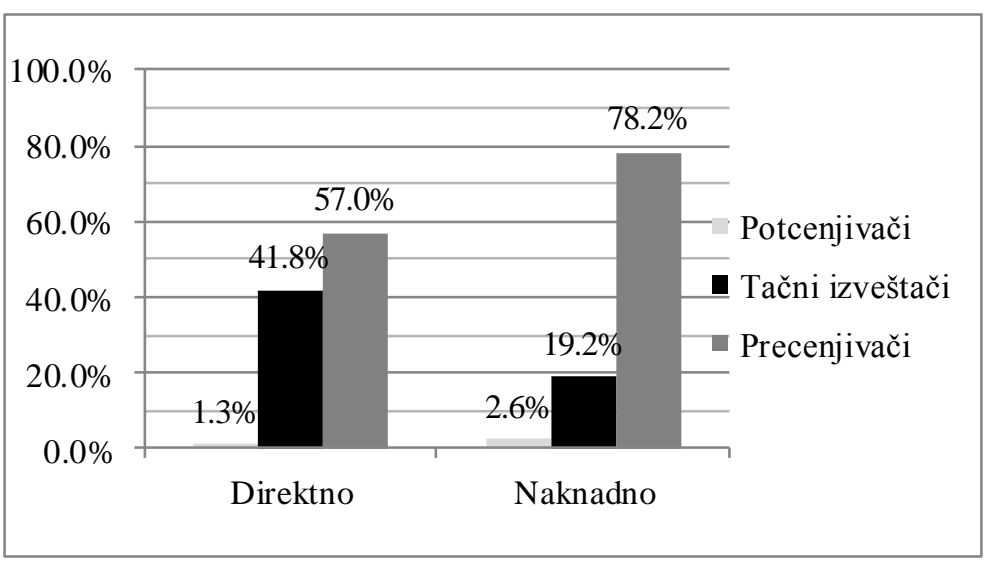

Grafikon 25. Zastupljenost potcenjivača, tačnih izveštača i precenjivača u izveštavanju o ukupnom skoru na testu u zavisnosti od memorijske dostupnosti događaja.

Na kraju, u grupi ispitanika koji su označeni kao neuspešni bilo je više precenjivača nego u uspešnoj grupi $\left(\chi^{2}(2)=6.508, p=.037\right)$ (Grafikon 26).

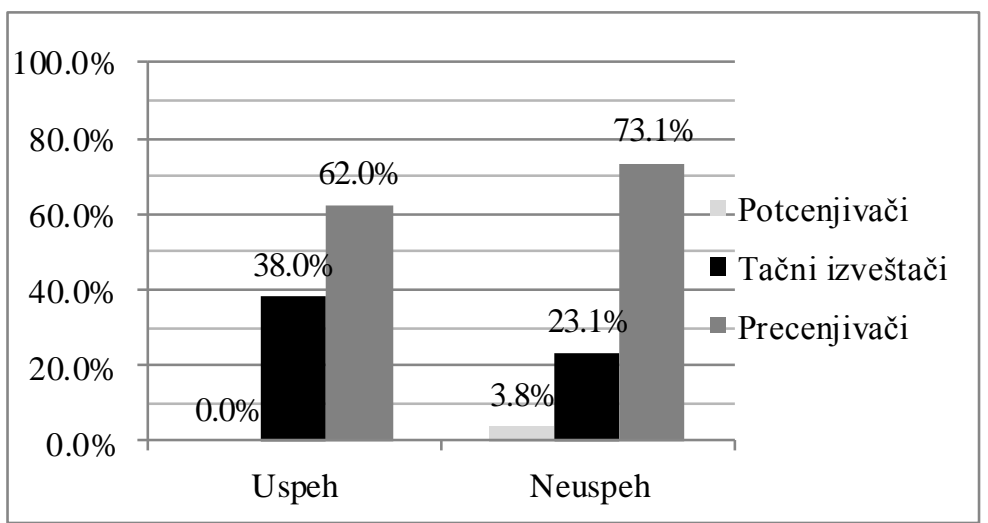

Grafikon 26. Zastupljenost potcenjivača, tačnih izveštača i precenjivača u izveštavanju o ukupnom skoru na testu u zavisnosti od fidbeka (o uspehu ili neuspehu). 


\section{Koliko ispitanici greše? Intenzitet greške preterivanja}

Kako su ispitanici i u ovom ogledu imali prilike da izveštavaju o postignućima na tri bloka u testu i ukupnom postignuću, ponovo smo proveravali da li se izmerena greška statistički značajno razlikuje od nule. U tri od četiri situacije, registrovana greška je značajno različita od nule i u očekivanom smeru (Tabela 14).

Tabela 14

Značajnost odstupanja greške preterivanja od nule u izveštavanju o tri bloka u testu $i$ ukupnom skoru na testu

\begin{tabular}{lcccc}
\hline & & & $\begin{array}{c}\text { Nivo } \\
\text { značajnosti }\end{array}$ & $\begin{array}{c}\text { Prosečna } \\
\text { razlika }\end{array}$ \\
\hline $\begin{array}{l}\text { Razlika saopštenog i tačnog skora na prvom } \\
\text { delu testa }\end{array}$ & 4.59 & 156 & .000 & 1.08 \\
$\begin{array}{l}\text { Razlika saopštenog i tačnog skora na drugom } \\
\text { delu testa }\end{array}$ & .19 & 156 & .850 & .04 \\
$\begin{array}{l}\text { Razlika saopštenog i tačnog skora na trecem } \\
\text { delu testa }\end{array}$ & 3.62 & 156 & .000 & .67 \\
$\begin{array}{l}\text { Razlika saopštenog i tačnog ukupnog skora } \\
\text { na testu }\end{array}$ & 11.09 & 156 & .000 & 1.56 \\
\hline
\end{tabular}

$\mathrm{Na}$ isti način kao u prethodnom ogledu, konstruisali smo zbir odstupanja u izveštavanju u sve četiri situacije, i dalje analize radili sa ovom zavisnom varijablom, kao i odstupanjem u izveštavanju o ukupnom skoru kao drugom zavisnom.

Intenzitet greške u zavisnosti od memorijske dostupnosti događaja. Analiza varijanse sa ponovljenim merenjima ukazala je na značajnu razliku u veličini zbirnog i odstupanja $u$ ukupnom skoru u zavisnosti od memorijske dostupnosti: kao i u prethodnim ogledima, ovaj nalaz se pokazuje robustnim, a efekti najsnažnijim $(F(1,157)=6.808, p=.01 ; F(1$, $157)=15.072, p=.000)$ : što je događaj koga se ispitanici prisećaju udaljeniji, veća je šansa da o njemu pristrasno izveštavaju (Grafikon 28). 


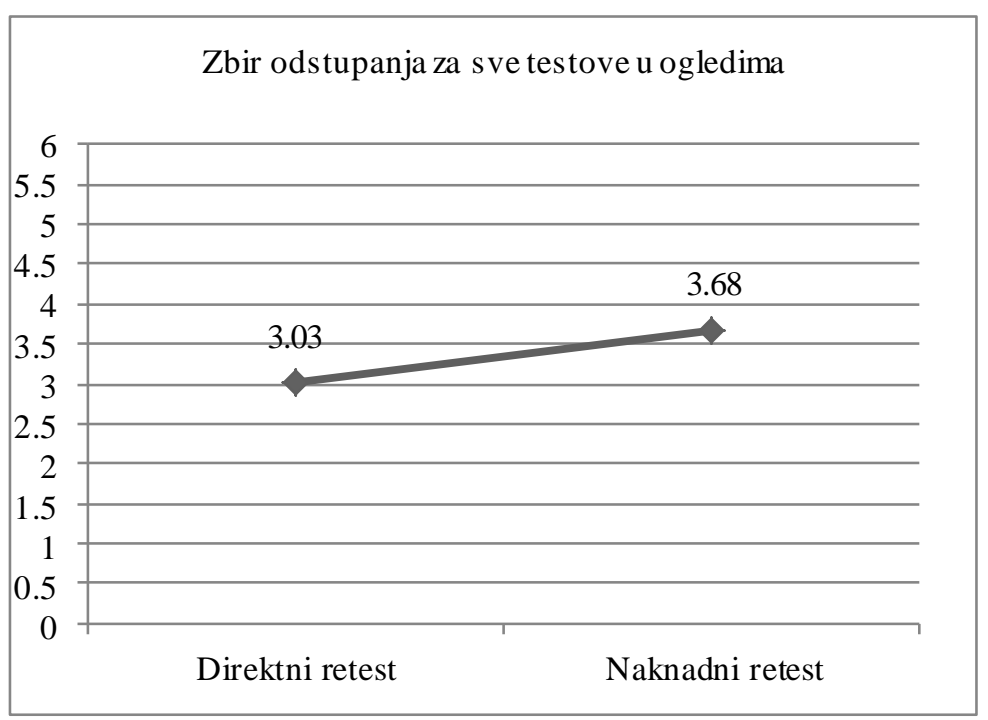

Grafikon 27. Zbirno odstupanje u izveštavanju u zavisnosti od memorijske dostupnosti.

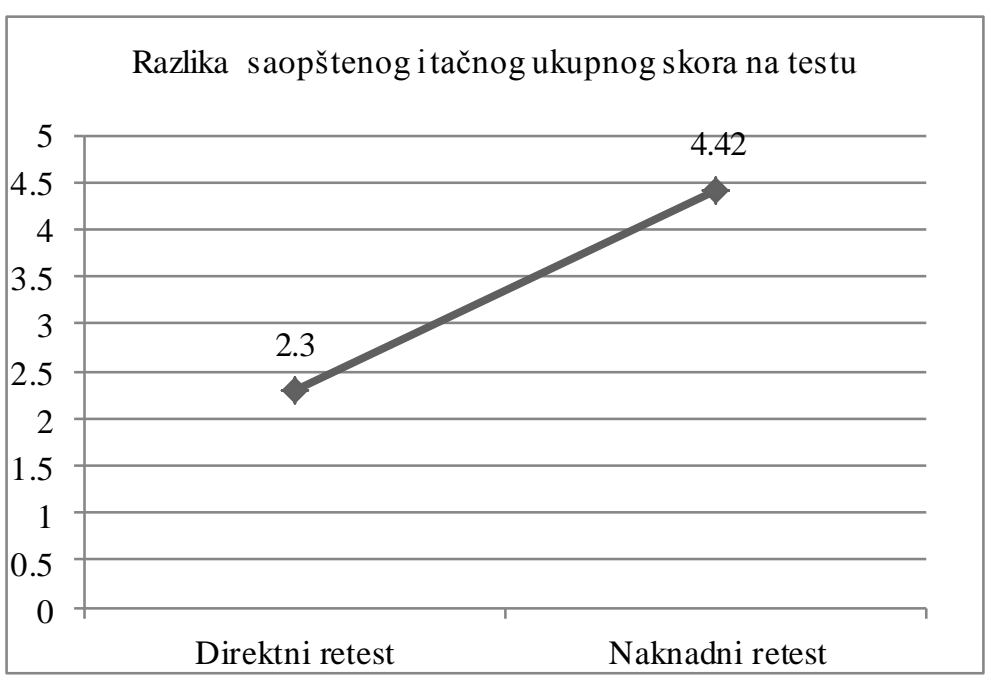

Grafikon 28. Odstupanje u izveštavanju o ukupnom skoru u zavisnosti od memorijske dostupnosti.

Intenzitet greške u zavisnosti od fidbeka o uspehu i javnosti situacije. Druga dva faktora imala su značajne efekte na po jednu od dve registrovane zavisne varijable: zbirna greška u izveštavanju bila je veća u "neuspešnoj" u poređenju sa "uspešnom" grupom ( $F$ (1, 157)=5.33, $p=.022$ ) (Grafikon 29), a nije bilo razlike u izveštavanju o ukupnom skoru (Grafikon 30); javnost situacije nije uticala na zbirno odstupanje (Grafikon 31), ali je grupa javno retestiranih značajno više grešila u izveštavanju o ukupnom skoru nego grupa privatno retestiranih $F(1,157)=3.704, p=.056)($ Grafikon 32). 


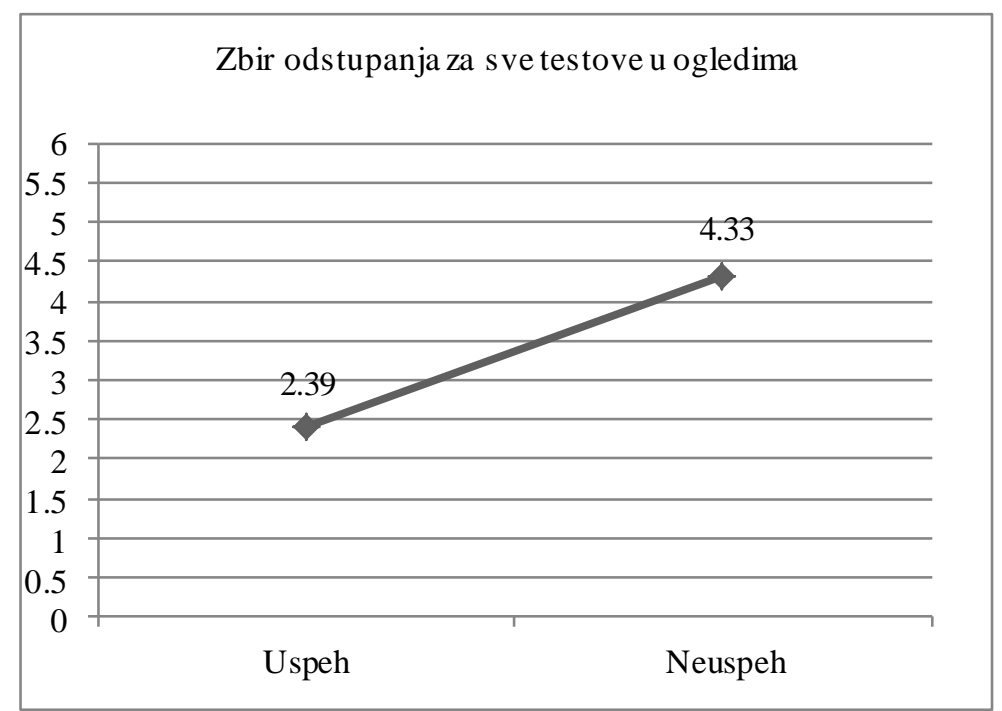

Grafikon 29. Zbirno odstupanje u izveštavanju u zavisnosti od uspeha odnosno neuspeha.

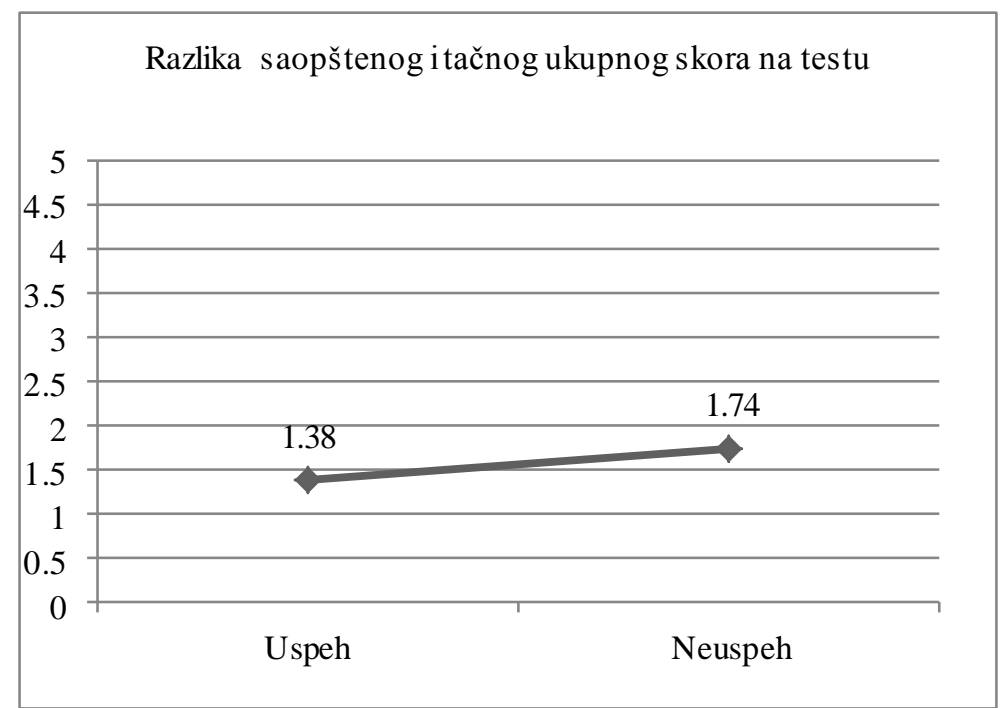

Grafikon 30. Odstupanje u izveštavanju o ukupnom skoru u zavisnosti od uspeha odnosno neuspeha.

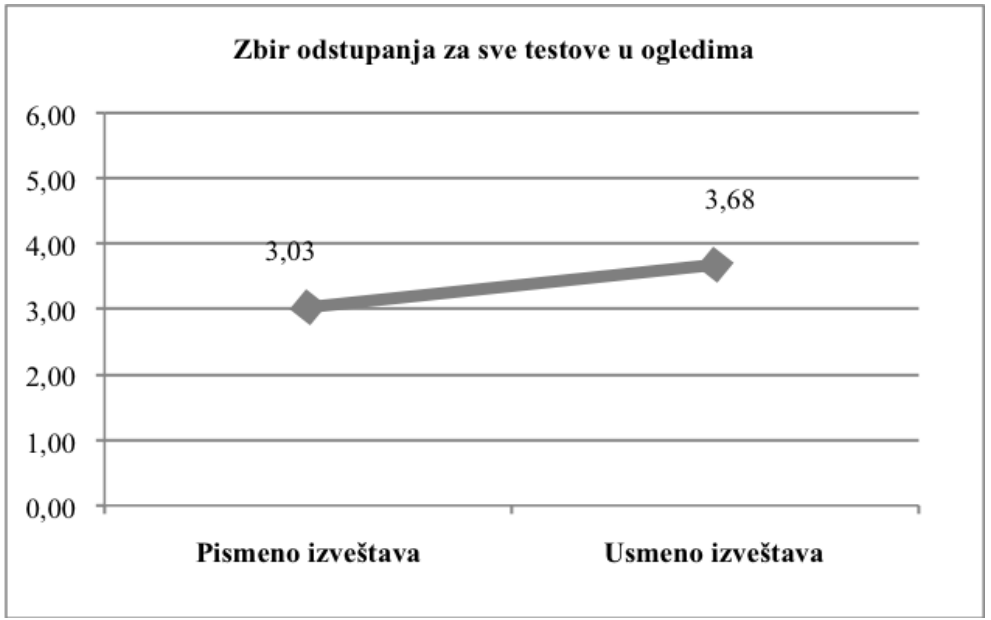

Grafikon 31. Zbirno odstupanje u izveštavanju u zavisnosti od javnosti situacije. 


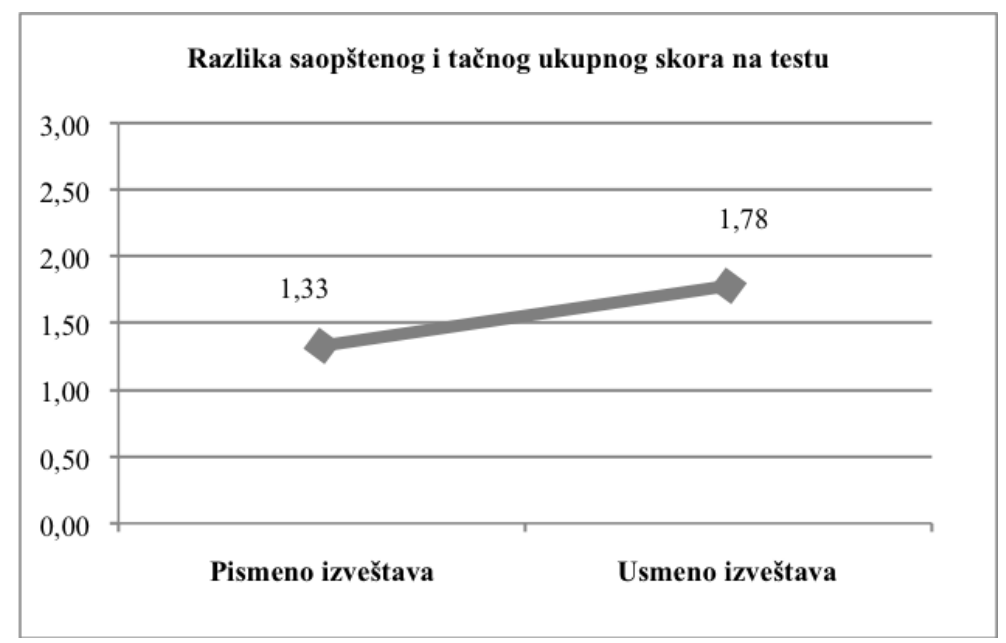

Grafikon 32. Odstupanje u izveštavanju o ukupnom skoru u zavisnosti od javnosti situacije.

Interakcije među faktorima. Jedina značajna interakcija registrovana je između javnosti situacije retestiranja i fidbeka o uspehu odnosno neuspehu $(F(1,157)=4.861, p=.029)$ : zbirno odstupanje u izveštavanju bilo je veće u usmenom nego u pismenom izveštavanju, ako je ispitanik dobijao povratnu informaciju o uspehu, a veće u pismenom nego u usmenom, ako je dobijao povratnu informaciju o neuspehu (Grafikon 33).

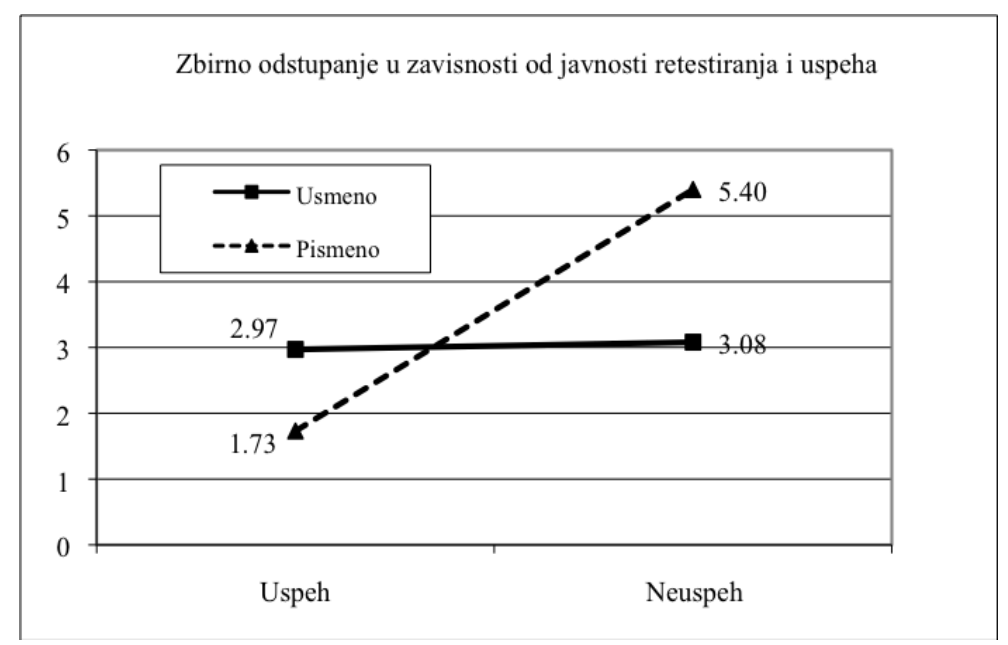

Grafikon 33. Zbirno odstupanje u izveštavanju u zavisnosti od javnosti retestiranja i fidbeka o uspehu odnosno neuspehu.

\section{Apsolutna greška u izveštavanju o postignuću na testovima}

Konačno, da bismo utvrdili postoje li razlike i u tačnosti izveštavanja nezavisno od toga da li je greška pozitivno ili negativno usmerena (da li je u pitanju precenjivanje ili potcenjivanje sopstvenih rezultata), analizirali smo podatke sa apsolutnim odstupanjem kao zavisnom 
varijablom. Sabiranjem apsolutnih grešaka u sve četiri situacije izveštavanja konstruisana je nova promenljiva nazvana zbirno apsolutno odstupanje, i u analizi varijanse sa ponovljenim merenjima ona je, uz apsolutno odstupanje u izveštavanju o ukupnom skoru, imala ulogu zavisne varijable.

Uticaj memorijske dostupnosti, fidbeka o uspehu i javnosti situacije. Naknadno retestirane grupe značajno su više grešile u izveštavanju nego direktno retestirane, kako u zbirnom apsolutnom odstupanju tako i u izveštaju o ukupnom skoru $(F(1,157)=16.634, p=.000 ; F(1$, $157)=17.88, p=.000)$. Pored toga, apsolutna greška bila je veća u izveštavanju o neuspehu nego o uspehu, i zbirno i u ukupnom skoru $(F(1,157)=5.875, p=.017 ; F(1,157)=3.081$, $p=.081$ ). Nije bilo razlike $\mathrm{u}$ apsolutnom odstupanju $\mathrm{u}$ zavisnosti od javnosti situacije retestiranja. U ovim analizama treba, međutim, uzeti u obzir da dve trećine ispitanika spada u precenjivače, odnosno da greška u izveštavanju u većini slučajeva ima pozitivan predznak, pa se ne može očekivati da se analiza apsolutne greške u mnogome razlikuje od analize odstupanja uključujući predznak.

\section{Povezanost sklonosti ka grešci preterivanja sa indikatorima psihološke adaptiranosti}

Sa rasponom greške preterivanja registrovanom u izveštavanju o postignuću na testu "socijalno-kognitivnih sposobnosti" značajno je povezana samo sklonost ka spontanom evociranju pozitivnih autobiografskih epizoda. Iako je bilo smisleno pretpostaviti da se u osnovi ublažavanja neuspeha i precenjivanja uspeha nalaze drugačije dispozicije, analize povezanosti na poduzorcima "uspešnih" i "neuspešnih" nisu dale drugačiju sliku (Tabele 4.5 i 4.6, Prilog 4). 
Tabela 15

Povezanost indikatora memorijskih pristrasnosti u izveštavanju o uspehu na testu "socijalnokognitivnih sposobnosti" sa indikatorima psihološke adaptiranosti

\begin{tabular}{|c|c|c|c|c|c|c|}
\hline & $\begin{array}{c}\text { Skor na skali } \\
\text { Akademskih } \\
\text { ambicija }\end{array}$ & $\begin{array}{c}\text { Skor na } \\
\text { Rozenbergovoj } \\
\text { skali } \\
\text { samopoštovanja }\end{array}$ & $\begin{array}{c}\text { Skor na } \\
\text { skali LOT } \\
\text { (životnog } \\
\text { optimizma) }\end{array}$ & $\begin{array}{l}\text { Skor na skali } \\
\text { dominantnog } \\
\text { raspoloženja }\end{array}$ & $\begin{array}{c}\text { Broj pozitivnih/ } \\
\text { ukupan broj } \\
\text { spontano } \\
\text { navedenih } \\
\text { sećanja }\end{array}$ & $\begin{array}{c}\text { Zbir } \\
\text { odstupanja } \\
\text { za sve } \\
\text { testove }\end{array}$ \\
\hline $\begin{array}{l}\text { Razlika saopstenog } \\
\text { i tacnog ukupnog } \\
\text { skora na testu }\end{array}$ & .10 & .10 & .09 & .01 & $.12\left(^{(}\right)$ & $.73(* *)$ \\
\hline $\begin{array}{l}\text { Zbir odstupanja za } \\
\text { sve testove }\end{array}$ & .09 & .08 & .00 & .01 & $.22(*)$ & \\
\hline
\end{tabular}

\section{Predviđanje raspona greške preterivanja}

U setu prediktora kao neznačajne pokazale su se sve dispozicione varijable, kao i samopredstavljanje i povratna informacija o uspehu (Tabela 16). Jedini značajan doprinos objašnjenju greške preterivanja daje memorijska dostupnost, a prediktori objašnjavaju 13\% varijanse u grešci u izveštavanju o ukupnom skoru $\left(R^{2}=.129, F(1,157)=2.65, p=.01\right)$. 
Tabela 16

Regresiona analiza sa greškom preterivanja kao zavisnom varijablom

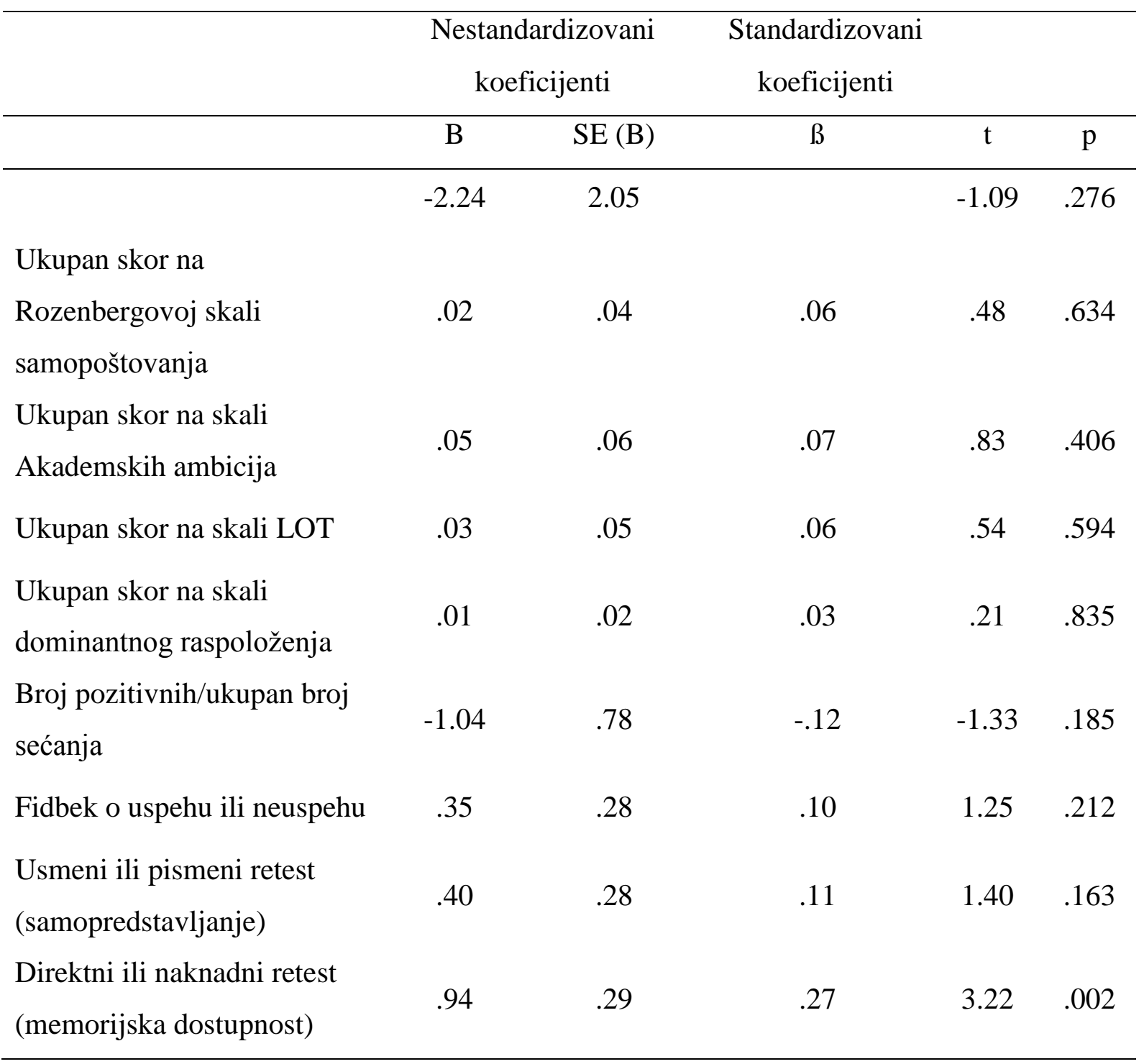

\section{Diskusija}

U ovom ogledu uveli smo još jedan značajan eksperimentalni faktor za koji smo očekivali da će uticati na izraženost greške preterivanja: uspeh odnosno neuspeh na konkretnom zadatku. Testovi koje smo kreirali bili su takvi da ispitanici nisu sa sigurnošću mogli da predvide da li su ih uradili dobro ili ne (u pitanju je bio takozvani "lažni test znanja", u kome se polazi od pretpostavke da ispitanici ne znaju tačan odgovor niti ga mogu znati, i da će odgovarati u 
skladu sa sopstvenim stavovima i slikom sveta). Pored toga, rezultat je bio saopštavan u formi percentilnog ranga, što je dodatno otežavalo njegovo potencijalno osporavanje (ne može se znati kako je isti test uradila referentna grupa u okviru koje se rangira pojedinačno postignuće). U razgovoru koji je sledio testiranje, nijedan ispitanik nije izrazio sumnju u verodostojnost dobijenog rezultata. Na osnovu rezultata prethodnih istraživanja, formulisali smo konkurentske hipoteze o tome da li će greška preterivanja biti izraženija u situaciji pozitivnog ili negativnog fidbeka. Većina istraživanja koja se bave načinom na koji ljudi interpretiraju sopstveni uspeh i neuspeh bave se atribucijama uzroka postignuća. Standardni nalaz ovih istraživanja je tendencija da se uspeh pripisuje unutrašnjim, a neuspeh spoljnim faktorima (Heider, 1958; Jones \& Nisbett, 1972) što se tumači kao "odbrambena atribucija". Ova istraživanja nisu direktno relevantna za formulisanje hipoteza u našem ogledu, pre svega zbog toga što ne izučavaju memorijske distorzije, već interpretaciju prošlih događaja, ali i zato što reakcije na uspeh i neuspeh porede pre svega u pogledu kvaliteta, ali ne i prema intenzitetu. U našem ogledu, rezultat samoafirmišuće strategije bio bi naglašavanje prošlih uspeha, a rezultat samozaštitne ublažavanje neuspeha. Više je istraživanja koja ukazuju na to da je snažnija potreba da anuliramo negativan fidbek (vidi npr. Alicke \& Sedikides, 2009), bilo zbog toga što se ne uklapa u postojeću sliku o sebi ili zbog toga što je evociranje takvih događaja jednostavno neprijatno. U istraživanjima koja su metodološki najsličnija našem, greška preterivanja bila je većinom izraženija kod neuspešnih subjekata: između indeksa preterivanja i akademskog uspeha utvrđena visoka negativna povezanost ( $\mathrm{r}=.66$, Gramzow et al., 2003); značajno je veća distorzija niskih nego visokih ocena u izveštavanju o srednjoj školi (Bahrick et al., 1993; 2008); ispitanici sa lošijim postignućem na testu su manje tačno i pristrasno izveštavali o rezultatima u poređenju sa grupom boljeg postignuća (Kruger \& Dunning, 1999). Postoje, međutim, i studije koje su dobile suprotne rezultate: $u$ istraživanju koje se bavilo iluzijom neizbežnosti, ona je bila izraženija u slučaju uspeha nego neuspeha, i to ne samo ličnih već i neuspeha nepoznatih osoba (Loui, 1999). U jednom od eksperimenata u kome se varirao kvalitet fidbeka (Gramzow \& Willard, 2009), uspešniji učesnici su više precenjivali sopstveno postignuće nego oni koji nisu dobili povratnu informaciju u koju kategoriju spadaju, a ova grupa je ipak precenjivala više od onih koji su dobili fidbek o neuspehu; razlike su bile još izraženije nakon nedelju dana (u grupi sa negativnim fidbekom u ovoj fazi registrovano je potcenjivanje, a ne precenjivanje). Istraživači su ovo tumačili rekonstruktivnim memorijskim procesima: ispitanici su se u prisećanju oslanjali na opšte uverenje o kvalitetu sopstvenog postignuća, tako da su oni koji su označeni kao neuspešni rekonstruisali niži, a oni označeni kao uspešni viši skor od zabeleženog. 
U našem ogledu je u obe grupe zabeležena greška preterivanja, s tim što je bila izraženija u grupi koja je dobila lošiji fidbek (rezultat ispod 50. percentila). Fidbek koji su ispitanici dobijali bio je isključivo numerički - nije bilo kvalitativne odrednice koja bi ispitanike kategorisala kao uspešne odnosno neuspešne, i moguće je da je upravo to ključ razlika u odnosu na pomenuti ogled Gramzova i Vilarda (Gramzow \& Wilard, 2009).

Izostao je glavni efekat javnosti situacije, iako su razlike bile u očekivanom smeru: veće memorijske distorzije zabeležene su u intervjuima. Precenjivanje postignuća je, međutim, registrovano i u pismenom upitničkom testiranju koje se odvijalo pod šifrovanim imenom. Pored toga, u našem ogledu registrovana je i značajna interakcija između javnosti situacije i uspeha/neuspeha: u slučaju privatnog izveštavanja, više je pristrasno korigovan neuspešni nego uspešni skor, dok je u slučaju javnog, više pristrasno korigovan uspešni nego neuspešni. Ovaj nalaz ide u prilog početnoj pretpostavci da je ublažavanje neuspeha samozaštitna, a precenjivanje uspeha strategija samopredstavljanja: privatna situacija u većoj meri provocira prvi, a javna drugi motiv.

Konačno, greška preterivanja i u ovom ogledu bila je izraženija u naknadnom nego $u$ direktnom retestu. Ovaj efekat se pokazuje robustnim i najsnažnijim u sva tri testiranja. U ovom ogledu, međutim, posebno je zanimljivo analizirati eventualne interakcije uspešnosti na testu i memorijske dostupnosti događaja. Ukoliko bi greška u pamćenju postignuća bila posledica rekonstruktivnog memorijskog procesa, u kome ispitanici zapravo na osnovu opšteg utiska o događaju rekonstruišu njegove pojedinačne detalje, vremensko udaljavanje od konkretnog događaja imalo bi za posledicu veći kontrast u upamćenim postignućima: neuspesi bi trebalo da se dalje umanjuju, a uspesi da se dalje povećavaju. Upravo je ovakva pravilnost registrovana u ogledu Gramzova i Vilarda (Gramzow \& Willard, 2009). Ukoliko bi greška u pamćenju postignuća bila primarno motivisana očuvanjem/unapređenjem slike o sebi ${ }^{22}$, očekivalo bi se da protok vremena ima za posledicu dalju distorziju u istom smeru i kod uspešnih i kod neuspešnih: povećavanja postignuća. Naši nalazi idu u prilog motivacionoj hipotezi, a može se navesti i nekoliko drugih empirijskih dokaza koji vode istom zaključku (vidi u Bahrick et al., 2008).

U korelacionoj i regresionoj analizi utvrdili smo da su memorijska dostupnost i pozitivnost autobiografskih sećanja jedine varijable značajno povezane sa registrovanom greškom preterivanja. Isti set prediktora koji smo koristili u prošlom ogledu (uz jednu različitu nezavisnu varijablu), u ovom objašnjava $13 \%$ varijanse greške preterivanja. Prosečna greška

\footnotetext{
${ }^{22}$ U ovom slučaju samozaštitu i samoafirmaciju tretiramo kao motivacione uzroke distorzije postignuća nasuprot kognitivnom rekonstruktivnom procesu.
} 
preterivanja $\mathrm{u}$ ovom ogledu je nešto veća nego u prethodnom, i iznosi u proseku 3.3 percentila. Skloni smo da ovo interpretiramo kao posledicu većeg potencijalnog raspona greške u nesupešnoj grupi, koja je u proseku i više grešila (u prethodnom ogledu svi ispitanici dobijali su fidbek o uspehu, sa percentilnim rangom iznad 70). Uprkos tome, raspon greške još uvek ostaje u domenu "prihvatljive amplitude", odnosno ne odstupa značajno od registrovanih rezultata. Svesni smo, svakako, da je teško operacionalizovati šta znači "prihvatljivo" odnosno "značajno" odstupanje, ali se čini da podaci ipak pružaju osnova da se zaključi da do značajnijih odstupanja nije došlo. Nije, na primer, registrovan nijedan slučaj "kvalitativnog skoka", odnosno transformacije neuspešnog skora u uspešni, za šta bi bilo potrebno korigovati skor za najmanje 20 percentilnih poena. 


\section{Eksperiment 4.1}

\section{Dizajn}

$\mathrm{U}$ ovom ogledu merila se greška preterivanja, ali u proceni uspešnosti u zadatku vizuelne percpcije i to za sebe ili drugoga. Da bismo proverili da li se i u kojoj meri javlja preuveličavanje postignuća i da li se javlja i u slučaju sopstvenog i u slučaju tuđeg postignuća, osmislili smo jednostavan jednofaktorski ogled u kome su učesnici slučajno podeljeni u dve grupe različito uključene u izvođenje zadatka: jedni su bili akteri a drugi posmatrači.

\section{Stimulus materijal}

Za potrebe ovog ogleda koristila su se dva bloka testa vizuelne percepcije, konstruisanog za prethodne oglede, i to Procena dužine linija i Procena broja tačaka. Za razliku od prethodne varijante testa, u ovoj su ispitanici nakon svakog zadatka dobijali povratnu informaciju o tačnosti odgovora (ukoliko je odgovor bio netačan, na ekranu se pojavljivao veliki crveni znak X).

\section{Procedura i učesnici}

Četrdeset studenata Fakulteta organizacionih nauka učestvovalo je u eksperimentu, i slučajno su razvrstani u jednu od eksperimentalnih grupa.m Jedna grupa radila je test vizuelne percepcije, a druga je posmatrala njihov rad i to tako da je svaki akter imao svog para (posmatrača). Posmatračima je rečeno da je neophodno da obrate pažnju na tip zadataka i odgovore njihovog laboratorijskog partnera. Parovi su radili izolovano jedni od drugih (pomoću kartonskih paravana), a eksperimentator je nadgledao da li posmatrači koncentrisano prate rešavanje testa. $U$ isto vreme radilo je tri do šest parova.

Zadatak aktera i posmatrača bio je da nakon svakog bloka daju svoju procenu uspešnosti rešavanja testa, izraženu preko procenta tačno rešenih zadataka. Smatramo da je ova procena bila zasnovana na njihovoj rekonstrukciji neposredno prethodećih dešavanja, i da se takođe može smatrati nekom vrstom memorijskog testa.

\section{Zavisna varijabla}

Zavisna varijabla bila je razlika između procene procenta tačnih odgovora date od strane aktera i procene procenta tačnih odgovora date od strane posmatrača, i to za oba subtesta. 


\section{Rezultati}

Kako je u ovom ogledu od suštinskog značaja uključenost, operacionalizovana preko statusa aktera ili posmatrača, sve analize rađene su na podgrupama, s obzirom da nije bilo osnove pretpostaviti da će akteri i posmatrači demonstrirati istu vrstu pristrasnosti.

I akteri i posmatrači imali su zadatak da nakon testa koji se sastojao iz dva dela, a u kome su dobijali povratnu informaciju o tačnosti pojedinačnih zadataka procene koliko je akter bio uspešan (koliko je procenata zadataka tačno rešio/la). Kao precenjivači označeni su akteri i posmatrači čija je procena bila veća od zabeleženog postignuća, tačni izveštači ${ }^{23}$ su oni čija je procena odgovarala zabeleženom postignuću, dok su potcenjivači oni čija je procena bila niža od zabeleženog postignuća.

Iako je u izveštavanju na oba subtesta među akterima bilo više precenjivača, a manje potcenjivača nego među posmatračima, ova disproporcija se pokazala značajnom samo na drugom subtestu $\left(\chi^{2}(2)=12.983, p=.002\right)$ (Grafikon 35). Dok su u grupi aktera najbrojniji bili precenjivači, u grupi posmatrača, najbrojniji su bili potcenjivači.

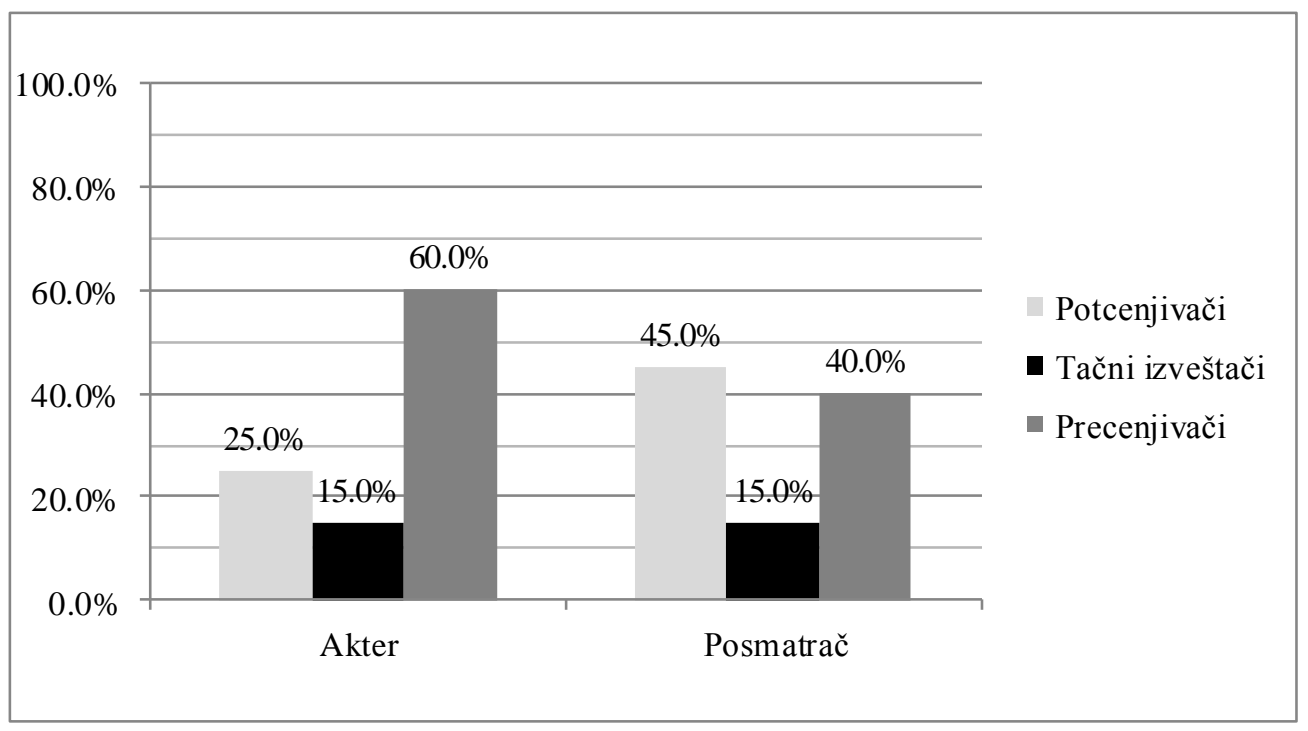

Grafikon 34. Zastupljenost potcenjivača, tačnih izveštača i precenjivača u izveštavanju o skoru na prvom subtestu u zavisnosti od uključenosti (akter ili posmatrač).

\footnotetext{
${ }^{23}$ Možda bi u ovom slučaju preciznije bilo reći "pogađači", ali je zadržana ista terminologija kao u prethodnim ogledima
} 


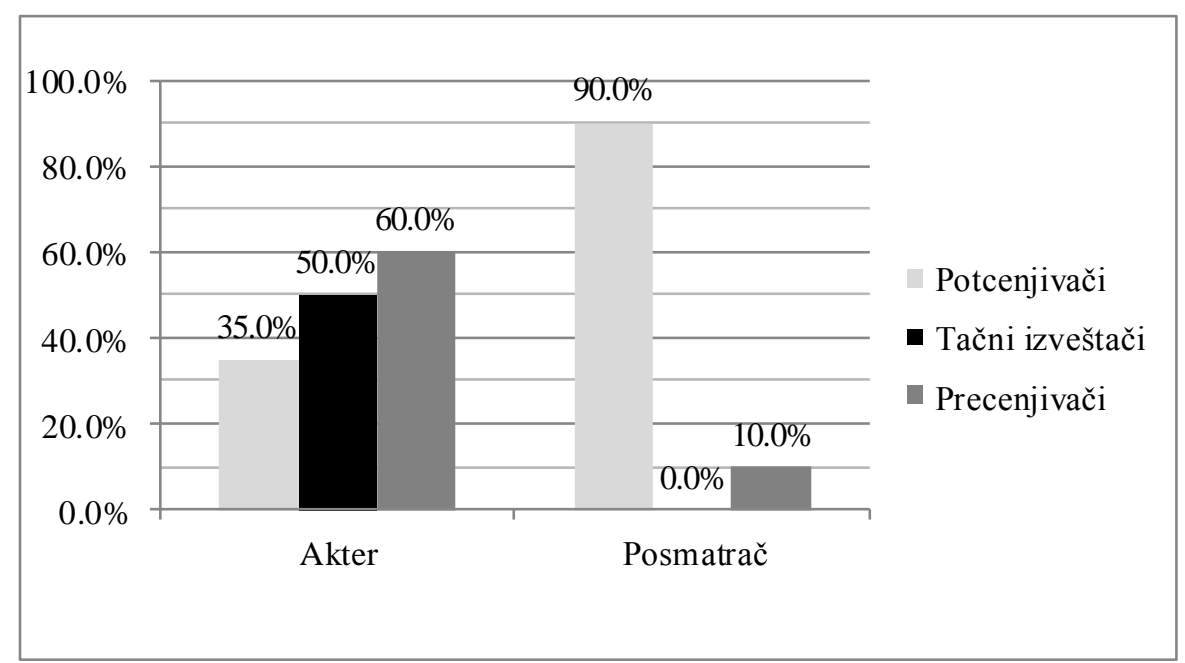

Grafikon 35. Zastupljenost potcenjivača, tačnih izveštača i precenjivača u izveštavanju o skoru na drugom subtestu u zavisnosti od uključenosti (akter ili posmatrač).

\section{Intenzitet greške u proceni postignuća}

Prvi korak u analizi bio je, kao i do sada, utvrđivanje da li se prosečna greška preterivanja na oba subtesta značajno razlikuje od nule, odvojeno za aktere i posmatrače. Greška je u tri od četiri slučaja bila značajno različita od nule, sa različitim predznacima: u slučaju aktera to je bila greška preterivanja, a u slučaju posmatrača, potcenjivanja učinka (Tabela 17).

Tabela 17

Značajnost odstupanja greške preterivanja od nule u izveštavanju na oba subtesta, za aktere $i$ posmatrače

\begin{tabular}{lcccc}
\hline & & & $\begin{array}{c}\text { Nivo } \\
\text { značajnosti }\end{array}$ & $\begin{array}{c}\text { Prosečna } \\
\text { razlika }\end{array}$ \\
\hline $\begin{array}{l}\text { Razlika procenjenog i tačnog skora na prvom } \\
\text { delu testa (akteri) }\end{array}$ & 2.46 & 19 & .024 & 3.58 \\
$\begin{array}{l}\text { Razlika procenjenog i tačnog skora na prvom } \\
\text { delu testa (posmatrači) }\end{array}$ & -.74 & 19 & .470 & -1.62 \\
$\begin{array}{l}\text { Razlika procenjenog i tačnog skora na drugom } \\
\text { delu testa (akteri) }\end{array}$ & 1.92 & 19 & .071 & 3.64 \\
$\begin{array}{l}\text { Razlika procenjenog i tačnog skora na drugom } \\
\text { delu testa (posmatrači) }\end{array}$ & -4.98 & 19 & .000 & -16.36 \\
\hline
\end{tabular}


Uticaj uključenosti. Uključenost, operacionalizovana preko izvođenja odnosno posmatranja aktivnosti, značajno je uticala na odstupanje u proceni postignuća na oba subtesta od registrovanog postignuća $(F(1,39)=3.89 ; p=.056 ; F(1,39)=27.759 ; p=.000)$ (Grafikon 36).

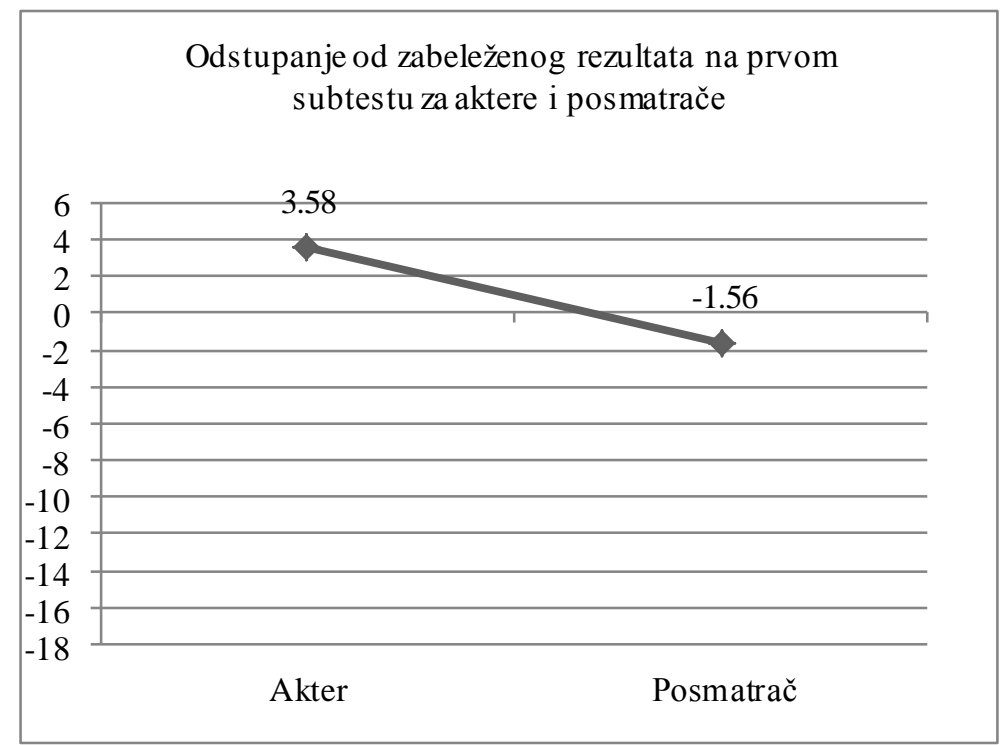

Grafikon 36. Odstupanje procene od zabeleženog rezultata na prvom subtestu, prema uključenosti.

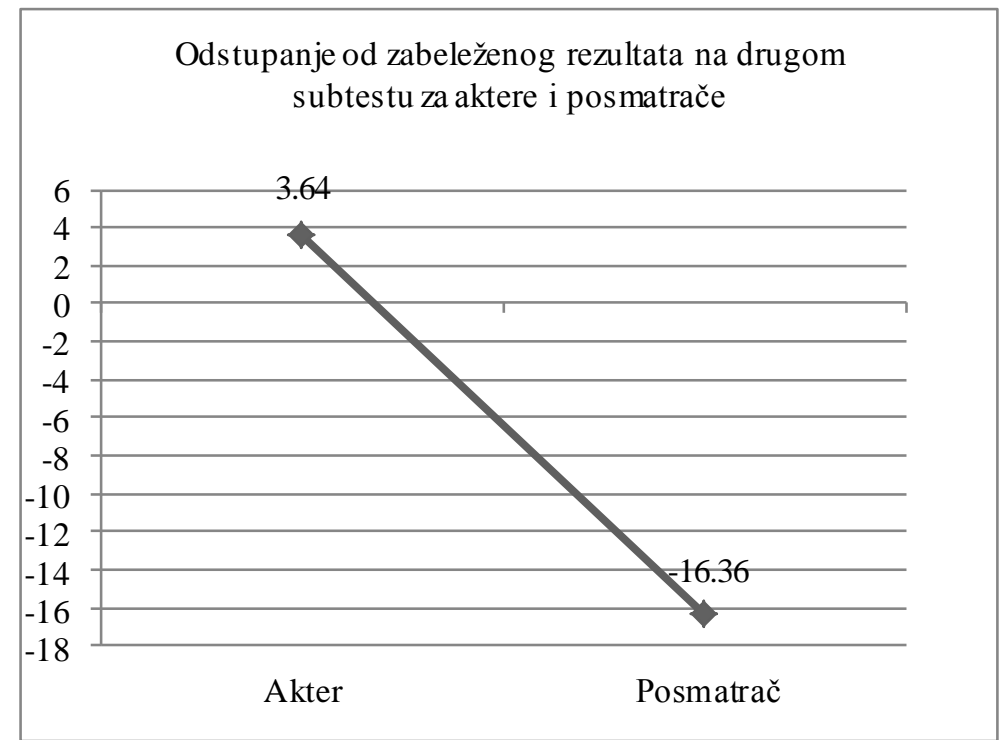

Grafikon 37. Odstupanje procene od zabeleženog rezultata na prvom subtestu, prema uključenosti. 


\section{Apsolutna greška u proceni postignuća}

Do sada smo utvrdili da akteri sistematski precenjuju, dok posmatrači sistematski potcenjuju učinak na testu. Prosečno preterivanje manje je od prosečnog potcenjivanja, kada se u računanju greške uzima u obzir predznak.

Uticaj uključenosti (akter/posmatrač). Da bismo proverili da li su akteri ili posmatrači tačniji u proceni učinka, analizirali smo razlike između ove dve grupe u apsolutnom odstupanju od registrovanog rezultata. Analiza varijanse pokazala je da su akteri tačniji u proceni od posmatrača (Grafikon 38$)$, s tim što je ova razlika značajna samo na drugom subtestu $(F(1$, 39)=26.487; $p=.000$ ). Uključenost utiče na tačniju i pozitivniju procenu; neuključeni ispitanici (posmatrači) daju nepreciznije procene i u proseku manje od stvarnog učinka.

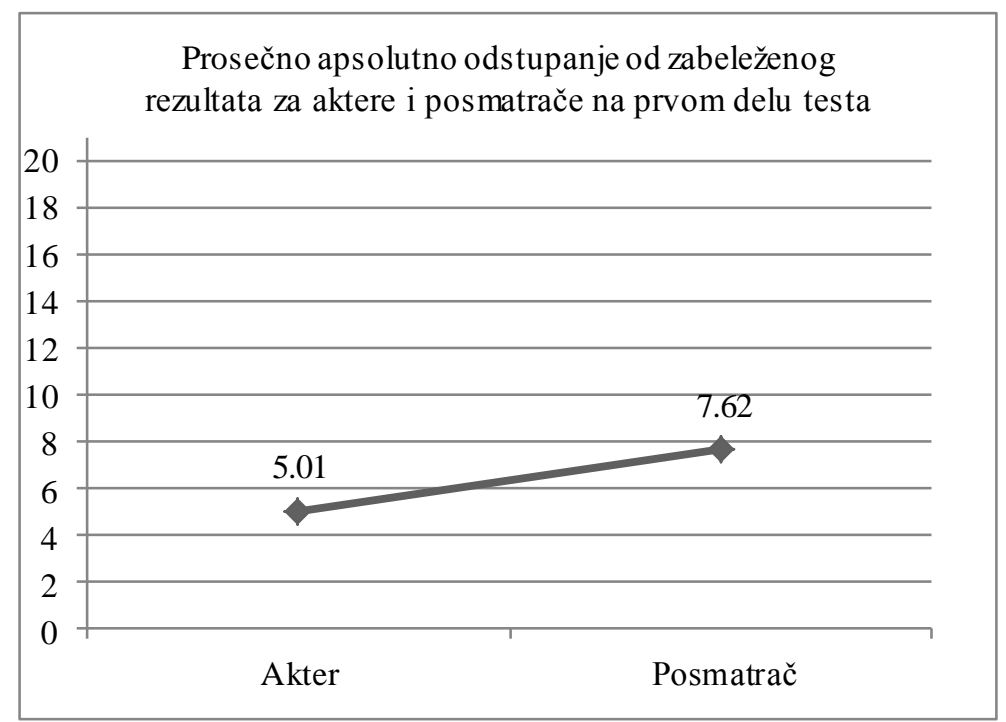

Grafikon 38. Prosečno apsolutno odstupanje procenjenog od zabeleženog rezultata na prvom subtestu. 


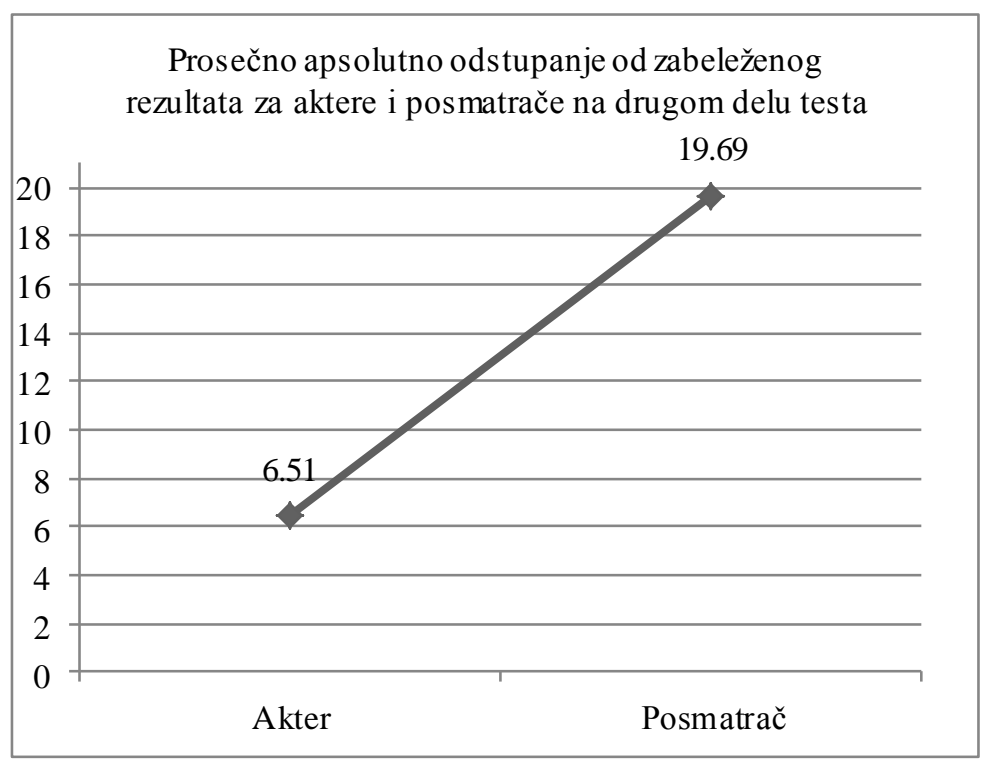

Grafikon 39. Prosečno apsolutno odstupanje procenjenog od zabeleženog rezultata na drugom subtestu.

Što se tiče korelacije greške u proceni sa indikatorima psihološke adaptiranosti, ona je bila smislena samo na uzorku "aktera" koji je bio relativno mali, tako da nijedna od utvrđenih povezanosti nije dostigla statističku značajnost (Tabela 4.7, Prilog 4).

\section{Predviđanje raspona greške preterivanja (potcenjivanja)}

Prediktorski skup objašnjava više od 20\% varijanse greške u izveštavanju na prvom subtestu, ali ova predikcija ne dostiže značajnost $\left(R^{2}=.211, F(1,39)=1.42, N s\right)$. Među prediktorima marginalno je značajna isključivo uključenost, operacionalizovana preko statusa aktera ili posmatrača (Tabela 18). Isti skup prediktora, međutim, objašnjava čak $46 \%$ varijanse greške u izveštavanju na drugom subtestu $\left(R^{2}=.459, F(1,39)=4.52, p=.002\right)$, a ponovo jedino uključenost značajno doprinosi prediviđanju (Tabela 19). 


\section{Tabela 18}

Regresiona analiza sa greškom preterivanja na prvom delu testa kao zavisnom varijablom

\begin{tabular}{|c|c|c|c|c|c|}
\hline & \multicolumn{5}{|c|}{ Standardizovani } \\
\hline & $\mathrm{B}$ & SE (B) & B & $\mathrm{t}$ & $\mathrm{p}$ \\
\hline & 38.06 & 18.77 & & 2.03 & .051 \\
\hline Akter ili posmatrac & -.98 & .53 & -.31 & -1.86 & .072 \\
\hline $\begin{array}{l}\text { Ukupan skor na Rozenbergovoj skali } \\
\text { samopostovanja }\end{array}$ & -.07 & .45 & -.04 & -.16 & .872 \\
\hline $\begin{array}{l}\text { Ukupan skor na skali Akademskih } \\
\text { ambicija }\end{array}$ & -3.79 & 2.57 & -.24 & -1.47 & .151 \\
\hline Ukupan skor na skali LOT & -.36 & .49 & -.15 & -.74 & .464 \\
\hline $\begin{array}{l}\text { Ukupan skor na skali dominantnog } \\
\text { raspoloženja }\end{array}$ & -.19 & .16 & -.24 & -1.21 & .235 \\
\hline Broj pozitivnih/ukupan broj sećanja & -8.46 & 7.56 & -.19 & -1.12 & .271 \\
\hline
\end{tabular}

Tabela 19

Regresiona analiza sa greškom preterivanja na drugom delu testa kao zavisnom varijablom

\begin{tabular}{|c|c|c|c|c|c|}
\hline & $\begin{array}{r}\text { Nestand } \\
\text { koef }\end{array}$ & $\begin{array}{l}\text { zovani } \\
\text { nti }\end{array}$ & $\begin{array}{c}\text { Standardizovani } \\
\text { koeficijenti }\end{array}$ & & \\
\hline & B & SE (B) & B & $\mathrm{t}$ & $\mathrm{p}$ \\
\hline & 10.78 & 30.77 & & .35 & .728 \\
\hline Akter ili posmatrac & -19.78 & 4.22 & -.63 & -4.68 & .000 \\
\hline $\begin{array}{l}\text { Ukupan skor na Rozenbergovoj } \\
\text { skali samopostovanja }\end{array}$ & .05 & .74 & .01 & .06 & .950 \\
\hline $\begin{array}{l}\text { Ukupan skor na skali Akademskih } \\
\text { ambicija }\end{array}$ & 1.02 & .86 & .16 & 1.18 & .246 \\
\hline Ukupan skor na skali LOT & .05 & .80 & .01 & .06 & .949 \\
\hline $\begin{array}{l}\text { Ukupan skor na skali dominantnog } \\
\text { raspoloženja }\end{array}$ & .09 & .26 & .06 & .36 & .720 \\
\hline $\begin{array}{l}\text { Broj pozitivnih/ukupan broj } \\
\text { sećanja }\end{array}$ & -7.01 & 12.40 & -.08 & -.56 & .576 \\
\hline
\end{tabular}




\section{Eksperiment 4.2}

\section{Dizajn}

U ovom jednofaktorskom ogledu takođe smo varirali uključenost preko statusa aktera odnosno posmatrača. Za razliku od prethodnog ogleda, posmatrači nisu prisustvovali samoj izradi testa, već su dobijali već popunjen test da ga ocene. Time se ovaj ogled dizajnom približio ogledima 2 i 3, s obzirom da su u njima ispitanicima saopštavana postignuća u formi percentilnog ranga.

\section{Stimulus materijal}

Na sličan način kao u prethodnom ogledu, i u ovom smo utvrđivali razlike između pamćenja sopstvenog i tuđeg postignuća. Konstruisali smo u tu svrhu test opšte kulture sa 20 pitanja (Prilog br 2). Pokušali smo da optimizujemo i težinu testa- cilj je bio da test bude umereno težak, odnosno da procenat uspešnosti varira između 20 i 60 posto tačno rešenih zadataka. $\mathrm{Na}$ odvojenom uzorku od 50 srednjoškolaca pretestom smo iz baze od 100 pitanja izdvojili 20 kod kojih je prosečan broj tačnih odgovora bio između 10\% i 50\%. Pitanja su pokrivala različite oblasti (film, književnost, istorija, hemija, biologija, astronomija) i bila različitog tipa (višestrukog izbora, kratkog odgovora ili Da-Ne tvrdnje). Uz svako pitanje postojala je kućica u koju je predviđeno uneti plus ili minus u zavisnosti od tačnosti odgovora.

\section{Procedura i učesnici}

Ispitanici su u ovom ogledu bili punoletni maturanti gimnazije Sveti Sava u Beogradu. Njih 46 je slučajnim izborom svrstano u jednu od eksperimentalnih grupa. Učešće je bilo dobrovoljno, a od ispitanika je dobijen informisani pristanak.

Polovina ispitanika radila je test, a zatim dobila ključ sa tačnim odgovorima. Njihov zadatak bio je da markiraju tačnost svakog odgovora, bez sabiranja konačnog skora. Druga polovina ispitanika dobijala je već popunjen test, uz uputstvo da ga prvo pažljivo pročitaju, a zatim ocene tačnost svakog odgovora na osnovu ključa. Obe grupe su nakon toga popunjavale bateriju testova i tek tada davale svoju procenu broja tačnih odgovora (za test koji su sami radili ili koji je radio neko drugi). Na taj način smo za isti test dobijali dva procenjena skora: od strane aktera i od strane posmatrača. Testovi su se radili pod šifrom, eksperimentalne grupe radile su u različito vreme tako da je anonimnost učesnika bila obezbeđena. 
Nakon ocenjivanja testa, ispitanici su davali svoju procenu ukupnog skora, i navodili zadatke sa testa čijeg se sadržaja sećaju (maksimalno pet). Svaki tačno reprodukovan zadatak nosio je jedan bod, tako da je raspon skora na reprodukciji bio 0-5.

\section{Zavisne varijable}

Zavisne varijable bile su (a) razlika između procene broja tačnih odgovora i stvarnog broja tačnih odgovora i (b) skor na reprodukciji sadržaja zadataka. U ovom eksperimentu uveli smo pamćenje konteksta (sadržaja zadataka) kao dodatnu zavisnu varijablu, u nameri da proverimo da li će se javiti razlike u tačnosti između aktera i posmatrača i da li će ove razlike biti istog smera kao i u slučaju pamćenja postignuća.

\section{Rezultati}

Kao i u prethodnom ogledu, više je bilo precenjivača među akterima nego među posmatračima, i više potcenjivača među posmatračima nego među akterima $\left(\chi^{2}(2)=12.6803, p=.002\right)$.

Tabela 20

Odnos potcenjivača, tačnih izveštača i precenjivača u izveštavanju o ukupnom skoru na testu, u zavisnosti od uključenosti

\begin{tabular}{lcccc}
\hline & \multicolumn{2}{c}{ Akteri } & \multicolumn{2}{c}{ Posmatrači } \\
\cline { 2 - 5 } & Frekvencije & Procenat & Frekvencije & Procenat \\
\cline { 2 - 5 } Potcenjivači & 3 & 13 & 14 & 60.9 \\
Tačni izveštači & 8 & 34.8 & 6 & 26.1 \\
Precenjivači & 12 & 52.2 & 3 & 30.4 \\
\hline
\end{tabular}

Kao što je i očekivano, akteri izveštavaju o višim skorovima, a posmatrači o nižim. Greška preterivanja kod aktera, međutim, nije statistički značajno različita od nule, dok kod posmatrača greška potcenjivanja jeste (Tabela 21). 
Tabela 21

Značajnost odstupanja greške preterivanja od nule, za aktere i posmatrače

\begin{tabular}{lcccc}
\hline & & & $\begin{array}{c}\text { Nivo } \\
\text { značajnosti }\end{array}$ & $\begin{array}{c}\text { Prosečna } \\
\text { razlika }\end{array}$ \\
\hline $\begin{array}{l}\text { Razlika procenjenog i tačnog skora na } \\
\text { prvom delu testa (akteri) }\end{array}$ & 1.39 & 22 & .179 & .44 \\
$\begin{array}{l}\text { Razlika procenjenog i tačnog skora na } \\
\text { prvom delu testa (posmatrači) }\end{array}$ & -3.44 & 22 & .002 & -1.30 \\
\hline
\end{tabular}

Razlika između aktera i posmatrača u proceni učinka pokazala se statistički značajnom $(F(1$, 44)=312.491 $p=.001)($ Grafikon 40).

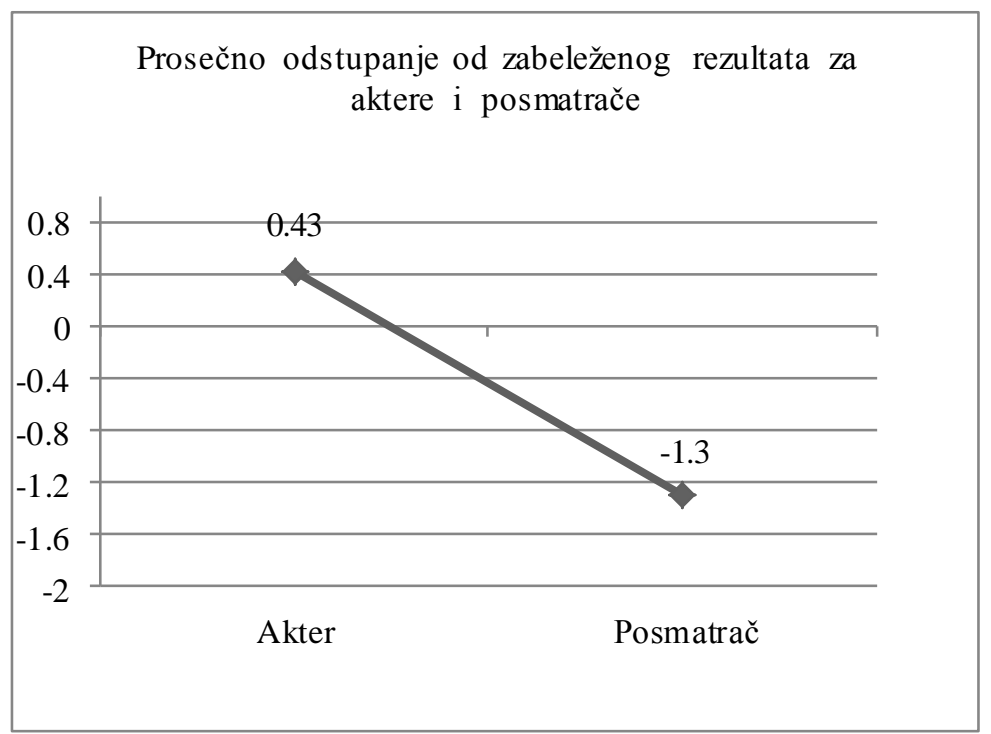

Grafikon 40. Prosečno odstupanje procenjenog od zabeleženog rezultata, u zavisnosti od uključenosti.

Akteri su i u ovom ogledu ispoljili pozitivnu pristrasnost, a posmatrači negativnu pristrasnost u proceni učinka. Da li se, međutim, razlikuju i prema tačnosti procene, odnosno prema apsolutnom iznosu greške?

Iako su akteri davali tačnije procene, analiza varijanse pokazala je da nema značajne razlike u tačnosti u zavisnosti od uključenosti $(F(1,44)=1.86 ; p=.179)$ (Grafikon 41). 


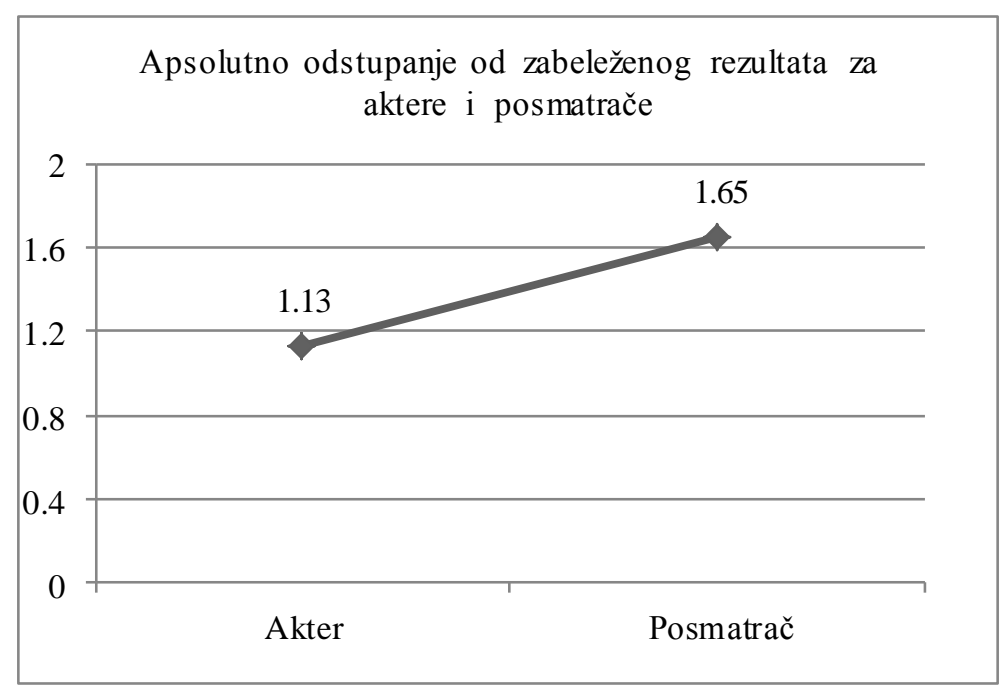

Grafikon 41. Prosečno apsolutno odstupanje procenjenog od zabeleženog rezultata, u zavisnosti od uključenosti.

Kada je u pitanju upamćenost sadržaja zadataka, akteri su u proseku upamtili 3.26 (1.63), a posmatrači 2.22 (1.56) zadataka, a ova razlika pokazala se statistički značajnom $(F(1$, 44)=4.90; $p=.032$ ). Bolje pamćenje konteksta ispitivanja od strane aktera može ukazivati na to da veća uključenost zapravo vodi dubljoj obradi informacija. Tome u prilog govori i nalaz o većoj tačnosti procena aktera u odnosu na procene posmatrača.

Ni u ovom slučaju, na poduzorku aktera, korelacije sa dispozicionim varijablama nisu se pokazale statistički značajnim (Tabela 4.7, Prilog 4). Zbog veoma malog uzorka, ovaj nalaz treba uzeti sa rezervom (ni korelacije veće od .4 nisu dostigle statističku značajnost). 


\section{Predviđanje raspona greške preterivanja (potcenjivanja)}

Skup prediktora objašnjava 33\% varijanse greške u izveštavanju $\left(R^{2}=.337, F(1,44)=3.129\right.$, $p=.014)$. Uključenost operacionalizovana preko učešća u aktivnosti u stvari je jedina varijabla koja daje značajan doprinos (Tabela 22), dok dispozicione varijable nisu značajno doprinele prediktivnoj moći modela.

Tabela 22

Regresiona analiza sa greškom preterivanja u izveštavanju o postignuću na testu opšte kulture kao zavisnom varijablom

\begin{tabular}{|c|c|c|c|c|c|}
\hline & $\begin{array}{l}\text { Nestan } \\
\text { ani koe }\end{array}$ & $\begin{array}{l}\text { ardizov } \\
\text { icijenti }\end{array}$ & $\begin{array}{c}\text { Standardizovani } \\
\text { koeficijenti }\end{array}$ & & \\
\hline & B & SE (B) & $\beta$ & $\mathrm{t}$ & $\mathrm{p}$ \\
\hline & 5.64 & 3.83 & & 1.4 & .150 \\
\hline Akter ili posmatrač & -1.87 & .52 & -.50 & -3.57 & .001 \\
\hline $\begin{array}{l}\text { Ukupan skor na Rozenbergovoj } \\
\text { skali samopoštovanja }\end{array}$ & .05 & .08 & .14 & .68 & .503 \\
\hline $\begin{array}{l}\text { Ukupan skor na skali } \\
\text { Akademskih ambicija }\end{array}$ & .06 & .11 & .08 & .52 & .605 \\
\hline Ukupan skor na skali LOT & -.18 & .11 & -.29 & -1.67 & .103 \\
\hline $\begin{array}{l}\text { Ukupan skor na skali } \\
\text { dominantnog raspoloženja }\end{array}$ & -.06 & .04 & -.31 & -1.56 & .128 \\
\hline $\begin{array}{l}\text { Broj pozitivnih/ukupan broj } \\
\text { sećanja }\end{array}$ & -.72 & 1.05 & -.10 & -.69 & .497 \\
\hline
\end{tabular}




\section{Diskusija}

Ponašanje ljudi moguće je opažati iz dve osnovne perspektive: aktera i posmatrača. Iako se služe istim procesima opažanja i zaključivanja, i to na osnovu isth izvora podataka, sadržaj onoga što opažaju akter i posmatrač, i još više, način na koji opažene događaje interpretiraju, često se dramatično razlikuju.

Većina istraživanja asimetrije akter-posmatrač sprovedena je u okviru atribucionih teorija, gde su se uglavnom ispitivale razlike u pripisivanju uzroka ponašanja (Gilbert, 1998; Jones \& Davis, 1965; Jones \& Nisbett, 1972; Kelley, 1967; Malle, 2006), uz nastojanje da se što preciznije povuku linije razgraničenja između intrapersonalne i interpersonalne atribucije (Havelka, 2008). Hajder (Heider, 1958) je prvi ukazao na to da će u većini situacija osoba svoje ponašanje pripisati uticaju sredine, a ponašanje drugog njegovim/njenim trajnim dispozicijama. Dalje, akter svoje ponašanje procenjuje kao varijabilnije nego ponašanje posmatrača; akter svoje stavove opaža kao manje usklađene nego stavove posmatrača; akter svoje ponašanje smatra manje predvidljivim od ponašanja posmatrača (Schwarz \& Wellens, 1997).

Nalazi istraživanja asimetrija akter-posmatrač u oblasti pamćenja ukazuju na efekat egoreferencije (ego involvirajući događaji, odnosno događaji u kojima smo učestvovali kao akteri, imaju povlašćen status u pamćenju), ali i preterivanja (veća je šansa da takvi događaji budu pristrasno upamćeni). Na primer, sećanje na sopstveni doprinos razgovoru često se ne podudara sa objektivnim parametrima analize razgovora: bolje se pamte sopstvene izjave nego izjave drugih učesnika, ali se i sistematski precenjuje lično učešće u razgovoru, procentualno izraženo (Miller et al., 1996). Rezultati istraživanja u kome se ispitivalo pamćenje razgovora sa partnerom ili nepoznatom osobom u slučajevima kada ta osoba iskazuje neprijateljstvo ili ne iskazuje, ukazali su na fenomen egotizma pamćenja: bolje su se pamtile sopstvene nego tuđe izjave (ego referencija), bolje se pamtio sadržaj prijatnih nego neprijatnih razgovora (hedonistička selekcija), ali su se u situacijama iskazivanja neprijateljstva bolje pamtile izjave partnera nego nepoznatih sagovornika. Autori (Samp \& Humphreys, 2007) skloni su da poslednji nalaz objasne pre svega motivaciono (kritike partnera pamte se da bi poslužile kao materijal za kontraargumentovanje), ali smatraju da je i efekat neočekivanosti značajan (partner koji iskazuje neprijateljstvo). Postoji ovde prostor i za diskusiju o pamćenju afektivno šaržiranog materijala, ali nas u ovom trenutku pre svega zanimaju razlike u sadržaju pamćenja koje su posledica statusa aktera odnosno posmatrača. U seriji zanimljivih ogleda Ginter i Alike ispitivali su kakav uticaj imaju diskreditujuće 
informacije na pamćenje sopstvenog i tuđeg uspeha (Guenther \& Alicke, 2008). Učesnici u ogledima su nakon testa i saopštavanja rezultata dobijali informaciju da su greškom upućeni na pogrešan taster za odgovore, pa se njihov rezultat ima smatrati slučajnošću. Tuđa postignuća bila su sistematski korigovana nakon što su posmatrači dobili ovu informaciju; sopstvena postignuća, međutim, ili nisu bila korigovana ili su bila korigovana u značajno manjoj meri.

Razlozi za ovakve asimetrije mogu biti saznajne prirode: dostupnost podataka, poznavanje aktera, mogućnost fokusiranja pažnje na događaje, ali i motivacione prirode (akteri mogu biti motivisani za izbegavanje ili donošenje nekih zaključaka). Neki od ovih faktora favorizuju pouzdanost zaključaka aktera (više raznovrsnih izvora informacija, informacije o prošlim ponašanjima i slično), a drugi posmatrača (oni mogu da se fokusiraju isključivo na događaje, bez faktora koji bi im remetili pažnju, i nisu posebno motivisani da donesu zaključke koji bi pogodovali slici o sebi koju ima akter). Kako je motivisano pamćenje tema našeg istraživanja, oglede smo osmislili tako da proverimo da li se i kod posmatrača, kao i kod aktera, može registrovati pozitivna memorijska distorzija ili je pak to isključiva karakteristika aktera. Ukoliko bismo utvrdili da su i posmatrači skloni grešci preterivanja, ona bi se mogla tumačiti sklonošću ljudi da u opažanju i izražavanju ističu pozitivne naspram negativnih aspekata. Ova pretpostavljena sklonost nazvana je Poliana efekat (Boucher \& Osgood, 1969; Matlin \& Stang, 1978) i predviđa dominaciju pozitivnog naspram negativnog u jeziku (veća frekvencija reči pozitivne nego negativne konotacije), pamćenju (veći broj upamćenih pozitivnih nego negativnih događaja) i mišljenju (veći broj spontano produkovanih misli pozitivne nego negativne valence). U ovom objašnjenju, dakle, ne bi bilo potrebe pozivati se na motivisane memorijske distorzije: greška preterivanja u proceni nečijeg postignuća interpretirala bi se kao posledica sklonosti ka favorizovanju pozitivnih događaja naspram negativnih. Ukoliko bi se greška preterivanja, međutim, registrovala samo kod aktera, tada bi bilo potrebno pozvati se na motivisano pamćenje, s obzirom da su i akter i posmatrač bili izloženi istom događaju, dobili o njemu identičan fidbek i retestirani nakon istog vremenskog perioda.

U našem istraživanju ispitivala se razlika između aktera i posmatrača u sadržaju upamćenog, tačnije u sklonosti ka pristrasnom iskrivljavanju događaja. Ispitanici su bili učesnici, odnosno posmatrači u testu vizuelne percepcije koji se sastojao iz dva bloka po 20 zadataka i dobijali povratnu informaciju o uspehu na svakom zadatku ali ne i na čitavom testu. U drugom ogledu ispitanici su popunjavali i ocenjivali ili čitali i ocenjivali test opšte kulture, pri čemu su takođe validirali pojedinačne odgovore ali ne i uspeh na čitavom testu. Njihov zadatak bio je da procene koliko je akter bio uspešan u oba bloka zadataka, odnosno na testu 
opšte kulture. Drugim rečima, da na osnovu parcijalnih fidbeka rekonstruišu ukupni skor. Naša je pretpostavka bila da će se prilikom rekonstrukcije i akteri i posmatrači oslanjati na pojedinačne događaje koje su upamtili, i na opšti utisak o uspešnosti koji su stekli. Dakle, iako je procena neposredno sledila samu test-situaciju, u njoj su su se prvenstveno oslanjali na memorijske procese.

Rezultati su ukazali na dve stvari: a. akteri su sistematski precenjivali, a posmatrači sistematski potcenjivali postignuća, ali i b. akteri su bili tačniji u svojoj proceni od posmatrača (u ogledu 4.2 ova razlika nije dostigla statističku značajnost, ali je razlika u broju tačno upamćenih zadataka bila značajna, u korist aktera). Uključenost, operacionalizovana preko statusa akter/posmatrač predviđala je 20\%, (nije značajno) odnosno $46 \%$ varijanse greške u ogledu 4.1, i 33\% varijanse greške u ogledu 4.2. Pre svega, kako objasniti razliku u proceni na dva subtesta vizuelne percepcije? Čini se da razlozi delimično leže u sadržaju i opaženoj težini testa. Prvi test je bio test uparivanja boja, a drugi procena broja tačaka $\mathrm{u}$ izloženoj konfiguraciji. Na drugom subtestu je ukupno uzevši, bilo mnogo više grešaka (u proseku 40\%), a zbog kratkog vremena ekspozicije tačaka i akteri i posmatrači imali su utisak da je zadatak težak i da se zasniva pre svega na pogađanju. Bilo je stoga očekivano da i jedni i drugi formiraju neki opšti utisak o uspešnosti odnosno neuspešnosti aktera, i da u skladu sa njim rekonstruišu jedan opšti skor. Verovatno su posmatrači bili spremniji da okarakterišu aktere kao neuspešne i bili stroži u proceni njihovih postignuća.

Zbog čega je značajno uporediti izveštaje aktera i posmatrača o istim događajima? Vrlo često se informacije o ispitanicima dobijaju na osnovu iskaza drugih, njima bliskih ili manje bliskih ljudi. Drugim rečima, o akterima se zaključuje na osnovu izveštaja posmatrača. U anketnim istraživanjima se, na primer, vrlo često od ispitanika traže odgovori i za članove njegove porodice. Uprkos posrednom načinu njihovog pribavljanja, pošto najčešće ostaju i jedini podaci, ovi izveštaji postaju osnovni izvor informacija o potrošačkim i zdravstvenim navikama, političkim preferencijama ne samo ispitanika već i njihovih bližnjih. Ove takozvane "proksi" mere na kraju se tretiraju kao legitimne procene učestalosti različitih ponašanja ili rasprostranjenosti stavova. U poslednje vreme se upravo zbog toga sprovode istraživanja koja mere korelaciju samoizveštaja i procena drugih (Schwarz \& Oyserman, 2001; Schwarz \& Wellens, 1997). Izmerene povezanosti većinom nisu zadivljujuće, a kreću se u velikom rasponu od .12 do .90 . Utvrđeno je da intenzitet povezanosti zavisi od čitavog niza faktora: bliskosti ukućana, poželjnosti ponašanja, učestalosti razgovora o konkretnoj temi, pri čemu lista potencijalnih moderatora ovim nipošto nije iscrpljena. Ova istraživanja nedvosmisleno ukazuju na nepodudarnost izveštaja aktera i posmatrača. Ona, međutim, ne 
govore ništa o tačnosti tih izveštaja, odnosno o tome čije procene više odgovaraju stvarnim događajima. Ogledi u našem istraživanju ukazuju na to da su izveštaji aktera, iako pozitivno pristrasni, istovremeno i tačniji od izveštaja posmatrača. Nalaz o tačnosti može biti čak i važniji nego nalaz o smeru pogrešaka, pogotovo kad se uzmu u obzir istraživanja u kojima su su rejtinzi drugih, bliskih ljudi ili nepristrasnih posmatrača, korišćeni kao kriterijum validacije samoprocene ispitanika (vidi u Colvin, Block \& Funder, 1995). U tim istraživanjima se osobe kod kojih postoji pozitivna nepodudarnost između načina na koji vide sebe i na koji ih vide drugi označavaju se kao osobe sklone samoosnaživanju; u ovakvim istraživanjima obično je ova grupa brojnija od druge dve, kod kojih se procene podudaraju ili su samoprocene negativnije od procena drugih. Naši podaci dovode u pitanje ovu vrstu "objektivnog kriterijuma". Ovim svakako ne želimo da generalizujemo i tvrdimo da su akteri uvek tačniji od nepristrasnih posmatrača, već da skrenemo pažnju na to da u nekim situacijama to može biti slučaj. U situaciji kakvu smo kreirali u ogledu, veća uključenost vodila je tačnijoj proceni postignuća. U ogledu u kome su testovi merili sposobnost manje značajnu za sliku o sebi (sposobnost vizuelne percepcije), raspon greške aktera bio je značajno veći od raspona greške posmatrača; u ogledu u kome je test merio značajniju sposobnost (znanje iz domena opšte kulture), ova razlika je bila $\mathrm{u}$ istom smeru ali ne i statistički značajna. Moguće da uticaj uključenosti na tačnost zavisi i od vrste uključenosti (Johnson \& Eagly, 1989), i da bi u situaciji u kojoj je mereno postignuće od većeg značaja za aktere ili ima stvarne posledice akteri bili manje tačni od posmatrača. 


\section{Eksperiment 5}

\section{Dizajn}

Pristrasnost ne mora nužno da se odnosi isključivo na sopstvena postignuća. Na sličan način preuveličavaju se postignuća i atributi grupa kojima pripadamo i sa kojima se identifikujemo. U ovom ogledu su eksperimentalno varirala pripadnost grupi (sopstvena i tuđa) i poredile su se greške u pamćenju u oba slučaja.

\section{Stimulus materijal}

Ispitanici su imali zadatak da pročitaju novinski članak u kome se izveštavalo u seriji navodnih studija pod pokroviteljstvom Evropske komisije u kojima su merene sposobnosti i osobine srednjoškolaca iz različitih zemalja Evrope. Članak je konstruisan po ugledu na izveštaje o rezultatima PISA testiranja u domaćoj dnevnoj štampi. Čitaocima je objašnjeno da se takva istraživanja sprovode u cilju prepoznavanja pravih potreba mladih i podsticanja saradnje u regionu, a da će materijal biti upotrebljen za unapređivanje Nacionalne strategije za mlade.

Rezultati navodnog istraživanja ukazivali su na to da se mladi iz Srbije i Rumunije razlikuju po nekim osobinama ličnosti: za jednu grupu rečeno je da su nadprosečno društveni, uporni, kreativni, skloni ljubomori ali neambiciozni i nesigurni u sebe. Za drugu grupu rečeno je da su odgovorni, staloženi, kreativni, nekomunikativni, gordi i pesimistično raspoloženi. U jednoj verziji članka prva grupa osobina pripisana je mladima iz Srbije a druga mladima iz Rumunije; u drugoj verziji članka bilo je obrnuto.

Da bi se kreirala dva uravnotežena profila (ujednačena po pozitivnosti navedenih osobina), sprovedeno je pilot istraživanje u kome je od 50 studenata psihologije traženo da navedu po pet poželjnih i pet nepoželjnih osobina ličnosti. Odabrane su zatim pozitivne odnosno negativne osobine koje su navođene sa istom učestalošću i pripisane jednoj odnosno drugoj grupi (iscrpna lista sa frekvencijama navođenih osobina data je u Prilogu 2).

Pored toga, čitaocima je saopšteno da su mladi radili i test intelektualnih sposobnosti, i data su prosečna postignuća na različitim subtestovima (verbalne, numeričke sposobnosti, prostorni odnosi, logički zadaci i ukupan skor) za obe grupe. U jednoj verziji članka jedan niz rezultata pripisan je mladima iz Srbije, $u$ drugoj su ista postignuća pripisana mladima iz Rumunije i obrnuto. 


\section{Procedura i učesnici}

U ovom ogledu učestvovalo je 63 punoletna maturanta i maturantkinje gimnazije Sveti Sava u Beogradu. Kao i u prethodnom, učešće je bilo dobrovoljno a ispitanici su dali informisani pristanak.

U prvoj fazi ispitanici su čitali jednu od verzija članka. Nakon toga popunjavali su bateriju testova, a zatim navodili osobine kojih se sećaju za jednu i drugu grupu, i popunjavali tabelu sa prosečnim postignućima za jednu i drugu grupu.

\section{Zavisne varijable}

Zavisne varijable bile su:

a. Broj atributa navedenih za svoju i tuđu grupu;

b. Indeks tačnosti atributa navedenih za svoju i tuđu grupu, izračunat kao odnos broja tačno navedenih atributa i ukupnog broja navedenih atributa. Procenu tačnosti vršila su zbog veće objektivnosti dva nezavisna procenjivača zato što su i sinonimi i atributi sličnog značenja priznavani kao tačni (npr.: društveni, socijalni, otvoreni ili kreativnimaštoviti isl.). U slučaju nepodudarnosti (javila se u manje od 5\% slučajeva), diskusijom su ustanovljavali zajednički kriterijum za priznavanje tačnih odgovora.

c. Indeks pozitivnosti atributa navedenih za svoju i tuđu grupu izračunat kao odnos broja pozitivnih atributa i ukupnog broja navedenih atributa, nezavisno od njihove tačnosti. I u ovom slučaju procene su vršila dva nezavisna procenjivača.

d. Razlika između saopštenih skorova na testu sposobnosti i skorova o kojima ispitanici izveštavaju, za sopstvenu i tuđu grupu. 


\section{Rezultati}

\section{Greška preterivanja u spontanom navođenju atributa svoje i tuđe grupe}

U ovom ogledu, prvi zadatak ispitanika bio je da spontano, bez podsećanja, navedu attribute koji su korišćeni za opis sopstvene i tuđe etničke grupe (Srba i Rumuna) u uvodnom članku. Pre svega, uporedili smo da li su ispitanici naveli različit broj atributa za svoju i tuđu grupu. Analiza varijanse sa ponovljenim merama pokazala je da je prosečan broj atributa navedenih za Srbe $(M s=2.96)$ značajno veći od prosečnog broja atributa navedenih za Rumune $(M r=2.32)(F(1,39)=16.21, p=.000)$. Konstruisali smo, zatim, indeks tačnosti atributa (odnos broja tačno navedenih atributa i ukupnog broja navedenih atributa), i ustanovili da se ne razlikuje u zavisnosti od toga da li su se ispitanici prisećali atributa svoje ili tuđe grupe. $\mathrm{Na}$ kraju, konstruisali smo i indeks pozitivnosti atributa (odnos broja pozitivnih ${ }^{24}$ i ukupnog broja navedenih atributa). Prosečan indeks pozitivnosti u prisećanju opisa Srba bio je 0.74, a Rumuna 0.41 , i ova razlika se pokazala statistički značajnom $(F(1,39)=16.21, p=.000)$.

Tabela 23

Analiza spontano navedenih atributa u prisećanju opisa sopstvene i tuđe grupe

\begin{tabular}{|c|c|c|c|c|c|c|c|c|}
\hline $\begin{array}{c}\text { Tačan } \\
\text { skor }\end{array}$ & & Min & Max & M & SD & $\mathrm{F}$ & $\mathrm{p}$ & $\mathrm{Eta}^{2}$ \\
\hline 6 & Broj navedenih atributa za Srbe $(\mathrm{N}=57)$ & 1 & 6 & 2.96 & 1.09 & & & \\
\hline & & & & & & 16.21 & .000 & .224 \\
\hline 6 & Broj navedenih atributa za Rumune $(\mathrm{N}=57)$ & 0 & 6 & 2.32 & 1.05 & & & \\
\hline $0-1$ & Indeks tacnosti atributa za Srbe $(\mathrm{N}=57)$ & 0 & 1 & 0.64 & 0.33 & & & \\
\hline & & & & & & .04 & .852 & .001 \\
\hline $0-1$ & Indeks tacnosti atributa za Rumune (N=57) & 0 & 1 & 0.65 & 0.38 & & & \\
\hline $0-1$ & Indeks pozitivnosti atributa za Srbe $(\mathrm{N}=57)$ & 0 & 1 & 0.74 & 0.26 & & & \\
\hline & & & & & & 31.78 & .000 & .362 \\
\hline $0-1$ & Indeks pozitivnosti atributa za Rumune $(\mathrm{N}=57)$ & 0 & 1 & 0.41 & 0.30 & & & \\
\hline
\end{tabular}

\footnotetext{
${ }^{24}$ Klasifikaciju atributa prema valenci vršila su dva nezavisna procenjivača. Inicijalno slaganje njihovih procena bilo je u više od 95\% slučajeva; ostali slučajevi svrstani su u kategorije nakon kratkih konsultacija.
} 


\section{Greška preterivanja u prisećanju postignuća svoje i tuđe grupe}

Drugi zadatak ispitanika bio je da se prisete skorova koje su postigli mladi Srbi i Rumuni na različitim testovima sposobnosti (verbalne, numeričke, logičke i snalaženje u prostoru) koji su saopšteni u članku koji im je prezentovan. U četiri od pet situacija, greši se pristrasno, u korist sopstvene grupe. U situacijama u kojima se izveštava o, u proseku višem skoru za obe grupe nego što je registrovan, greši se više u izveštavanju o sopstvenoj grupi; u situacijama u kojima se izveštava o nižem skoru za obe grupe, više se greši u izveštavanju o tuđoj; registrovana je i situacija u kojoj se prosečno postignuće soptsvene grupe precenjuje, a tuđe potcenjuje, ali ne i obrnuta situacija (Tabela 24).

Tabela 24

Razlike saopštenih i tačnih skorova za sopstvenu i tuđu grupu

\begin{tabular}{|c|c|c|c|c|c|c|c|c|}
\hline $\begin{array}{c}\text { Tačan } \\
\text { skor }\end{array}$ & & Min & Max & M & SD & F & $\mathrm{p}$ & $\mathrm{Eta}^{2}$ \\
\hline 45 & Razlika saopštenog i tačnog broja poena na & -31 & 24 & 2.36 & 11.07 & & & \\
\hline 55 & $\begin{array}{l}\text { prvom testu za Srbe } \\
\text { Razlika saopštenog i tačnog broja poena na } \\
\text { prvom testu za Rumune }\end{array}$ & -31 & 20 & 1.92 & 10.46 & .223 & 639 & .004 \\
\hline 67 & Razlika saopštenog i tačnog broja poena na & -32 & 2 & -13.8 & 14.24 & & & \\
\hline 65 & $\begin{array}{l}\text { drugom testu za Srbe } \\
\text { Razlika saopštenog i tačnog broja poena na } \\
\text { drugom testu za Rumune }\end{array}$ & -31 & 2 & -16.6 & 14.30 & 7.952 & .007 & .142 \\
\hline 55 & Razlika saopštenog i tačnog broja poena na & -26 & 33 & 4.08 & 12.27 & & & \\
\hline 62 & $\begin{array}{l}\text { trećem testu za Srbe } \\
\text { Razlika saopštenog i tačnog broja poena na } \\
\text { trećem testu za Rumune }\end{array}$ & -39 & 10 & -1.34 & 4.20 & 3.773 & .058 & .074 \\
\hline 49 & Razlika saopštenog i tačnog broja poena na & -26 & 33 & 4.08 & 12.27 & & & \\
\hline 36 & $\begin{array}{l}\text { četvrtom testu za Srbe } \\
\text { Razlika saopštenog i tačnog broja poena na } \\
\text { četvrtom testu za Rumune }(\mathrm{N}=48)\end{array}$ & -39 & 28 & 1.26 & 15 & 3.151 & .082 & .060 \\
\hline 56 & Razlika saopštenog i tačnog broja poena na & -8 & 12 & 0.37 & 2.57 & & & \\
\hline 59 & $\begin{array}{l}\text { četvrtom testu za Srbe } \\
\text { Razlika saopštenog i tačnog broja poena na } \\
\text { četvrtom testu za Rumune }(\mathrm{N}=57)\end{array}$ & -23 & 10 & -1.34 & 4.20 & 19.88 & .000 & .265 \\
\hline
\end{tabular}

Primeri korišćenih strategija. Prilikom unosa odgovora ispitanika, otkrili smo primere korišćenja različitih memorijskih strategija. Čini se da su se ispitanici oslanjali na opšti utisak na osnovu koga su rekonstruisali pojedinačne skorove, i da su spontano poredili skorove dve "konkurentske grupe", pamteći često samo koja je bila uspešnija (Slike 11 i 12). 


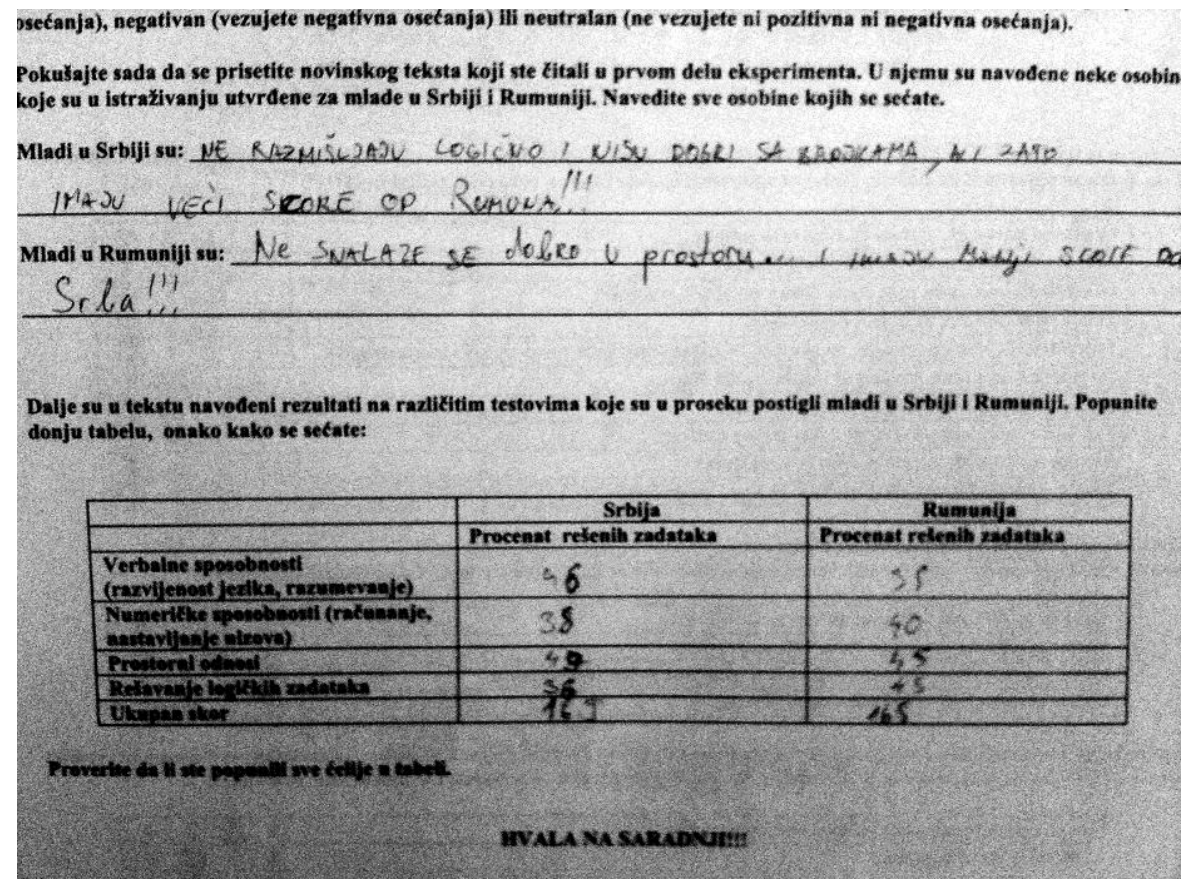

Slika 11. Primer poređenja među grupama i pamćenja opšteg tona.

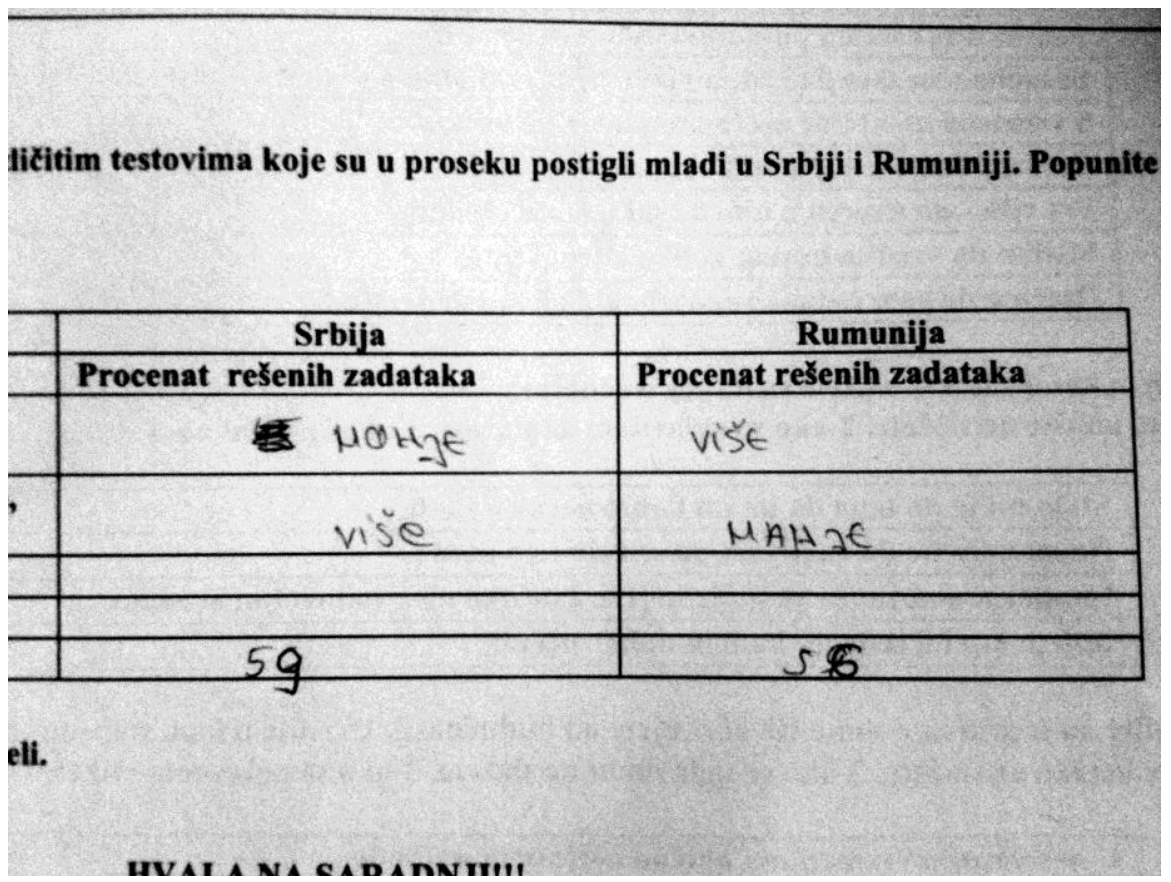

Slika 12. Primer poređenja među grupama.

Kada je reč o pamćenju konkretnih atributa, ispitanici su pravili nekoliko tipova grešaka koji su vodili pristrasnoj evaluaciji sopstvene grupe.

Izostavljanje ili ublažavanje negativnih atributa. U prisećanju opisa sopstvene grupe, često su izostavljali negativne osobine ili ih neutralisali dodavanjem kvantifikatora (pomalo, malo) (Slika 13). 


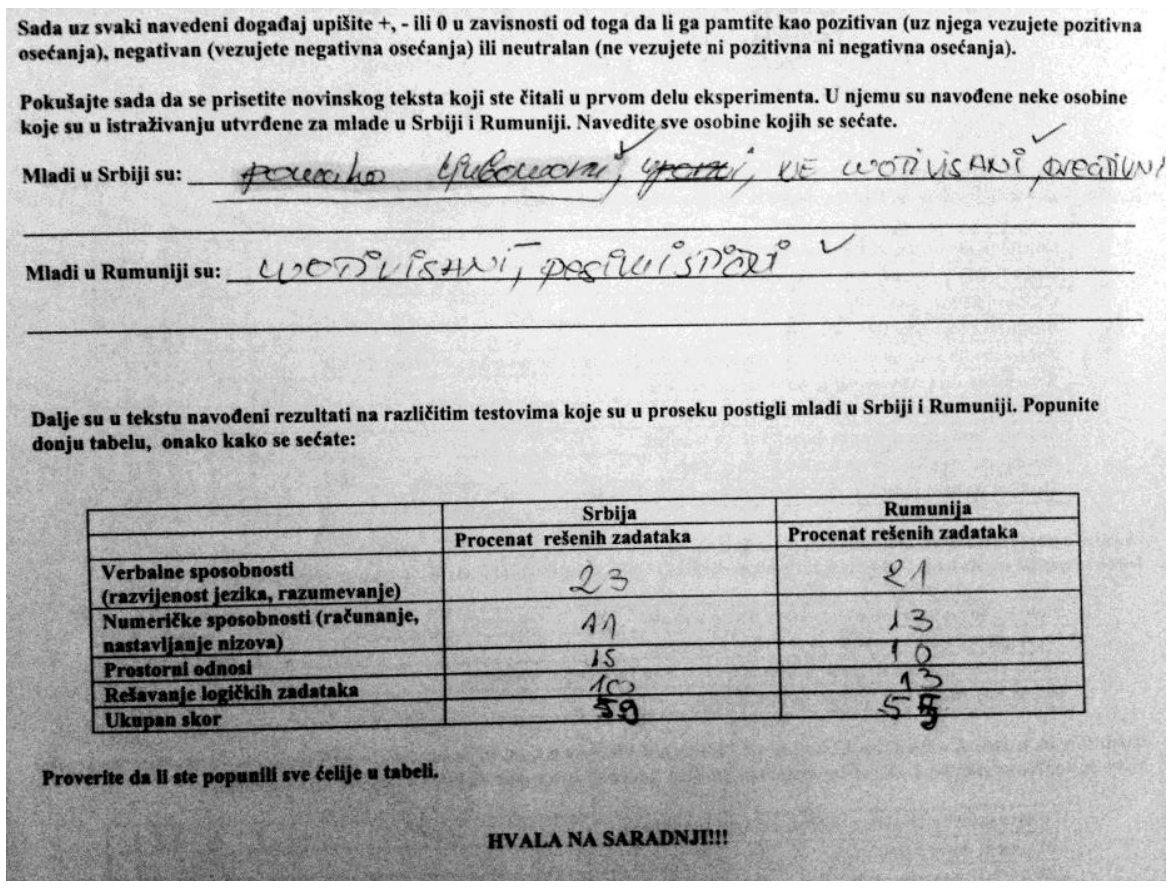

Slika 13. Primer ublažavanja negativnih osobina sopstvene grupe.

Dodavanje pozitivnih atributa. Kao komplementarnu strategiju neki su dodavali pozitivne attribute u opis sopstvene grupe. To su bili ili atributi sličnog značenja kao oni dati u osnovnom tekstu, verovatno da se ne bi narušio opšti ton (Slika 14), ili stereotipni atributi, kao deo zajedničkog znanja, koji su se "učitavali" u opise etničkih grupa (Slika 15).

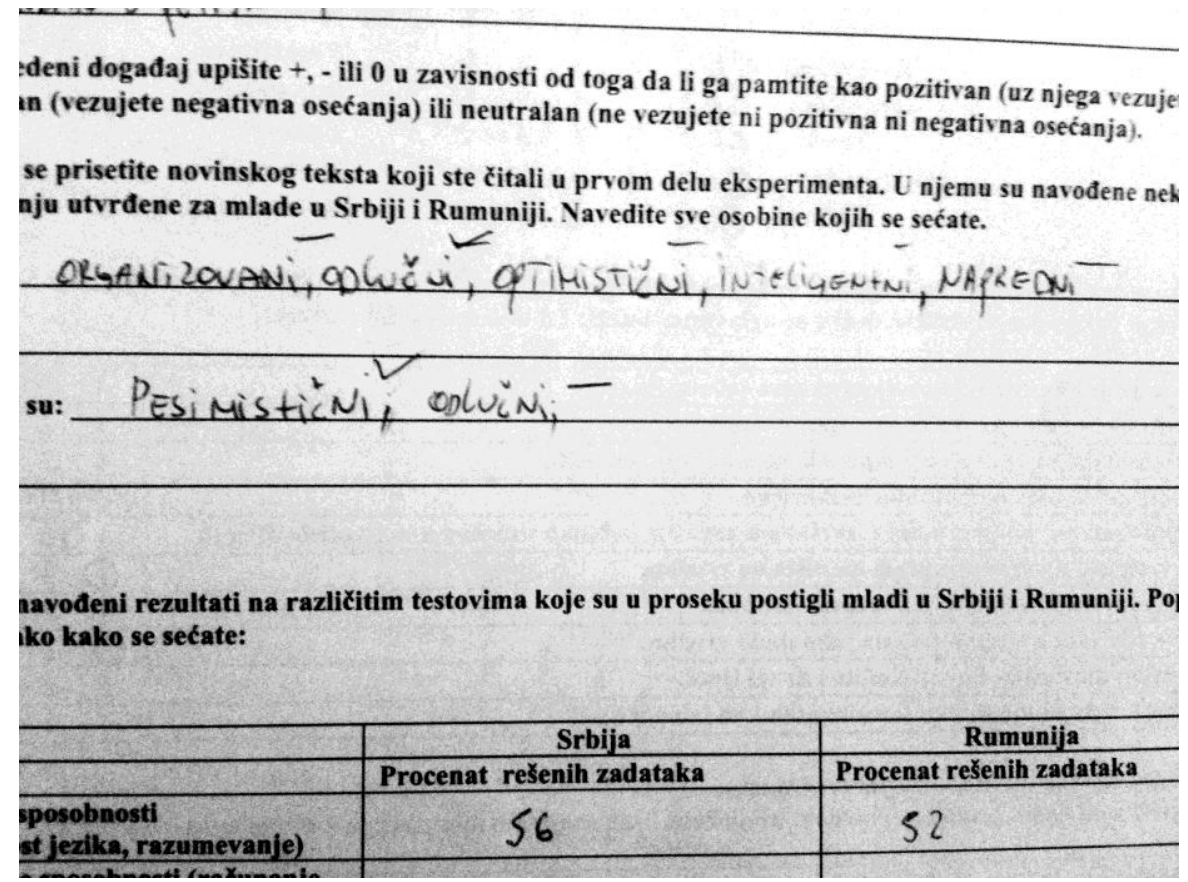

Slika 14. Dodavanje pozitivnih atributa opisu sopstvene grupe. 


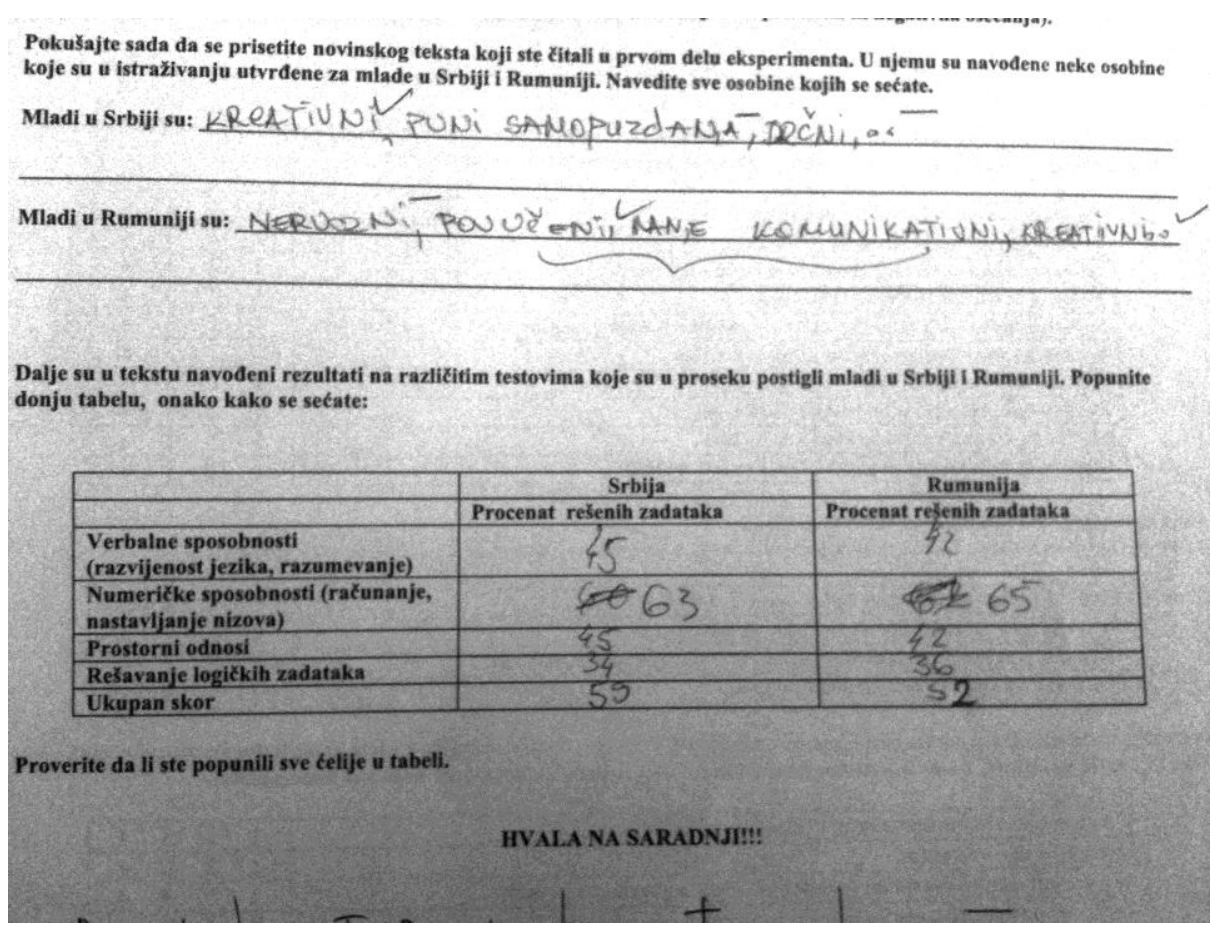

Slika 15. Dodavanje pozitivnih stereotipnih atributa opisu sopstvene grupe.

Bilo je, naravno, i drugačijih primera: dodavanja negativnih osobina (stereotipnih ili ne) opisu sopstvene grupe, i pozitivnih opisu tuđe. Ovi slučajevi su, međutim, bili značajno ređi, o čemu govori i konačni indeks pozitivnosti opisa. Zbog velikog broja različitih strategija koje su ispitanici koristili, mogućnosti da isti ispitanik koristi više od jedne strategije i/ili da se efekti različitih strategija preklapaju pa ih je teško prepoznati, u ovom radu zadržali smo se na anegdotskom prikazu pojedinih slučajeva. Buduća istraživanja mogla bi se usmeriti na detaljnije proučavanje procesa memorijskih distorzija, za šta bi bilo korisno razviti detaljan sistem kodifikacije mogućih strategija i porediti učestalost njihovog korišćenja i faktore od kojih to zavisi. 


\section{Diskusija}

U prethodnom ogledu konfrontirali smo perspektive aktera i posmatrača; dobijena je jasna pristrasnost u korist aktera. U istraživanjima koja su se bavila poređenjem načina na koji se pamte informacije o sebi i drugome (Green \& Sedikides, 2004; Sedikides \& Green, 2000, 2004) ispitanici su dobijali fidbek o tome koja ponašanja se na osnovu testa ličnosti mogu očekivati od njih, i koja se mogu očekivati od izvesne imaginarne osobe (u ovoj seriji ogleda ona je dobila ime Kris). Ponašanja su bila različite valence, prethodno procenjena kao poželjna odnosno nepoželjna. Obrazac po kome su se pamtile dobijene povratne informacije bio je začuđujuće dosledan: učesnici su se prisećali više pozitivnih nego negativnih ponašanja kada je u pitanju bio samoopis; pored toga, prisećali su se više negativnih ponašanja kada je u pitanju bio Kris, nego kada je u pitanju bio samoopis. Sedikides i Grin su ovaj fenomen interpretirali kao dejstvo takozvanog memorijskog zanemarivanja (memory neglect, Sedikides, Green \& Pinter, 2004): prilikom procesa pamćenja utvrđuje se da li su informacije ugrožavajuće za sliku o sebi ili nisu; ukoliko jesu, proces se prekida u ranoj fazi i informacije ne bivaju zapamćene (ili bivaju modifikovane tako da predstavljaju manju opasnost po sliku o sebi). U slučaju obrade negativnih informacija o drugome, one nisu ugrožavajuće i proces njihovog zapamćivanja se neometano nastavlja. Otuda se može očekivati i asimetrija kada je u pitanju odnos zapamćenih pozitivnih i negativnih informacija o sebi, ali i asimetrija $u$ količini zapamćenih negativnih informacija o sebi i o drugome. Pitanje na koje smo pokušali da odgovorimo u drugom ogledu je Da li se ovakve pravilnosti mogu očekivati i kada nije u pitanju pojedinac nasuprot drugom, nepoznatom pojedincu, već kad je u pitanju naša, nasuprot tuđoj grupi.

Prema teoriji socijalnog identiteta (Tajfel \& Turner, 1986) ljudi grade svoje identitete na osnovu pripadnosti različitim grupama: priroda članstva u grupi definiše čovekov identitet i samoprocenu. Iz ovoga sledi da ljudi prirodno žele da budu članovi grupa koje imaju viši status i pozitivniji imidž. Postoji više načina na koji ljudi održavaju sliku višeg statusa svoje grupe: porede sa grupom nižeg statusa ili biraju kategorije u kojima je poređenje povoljnije za njihovu grupu, b. ignorišu ili redefinišu negativne elemente identiteta grupe kojoj pripadaju, ili c. ignorišu ili redefinišu pozitivne elemente identiteta grupe kojoj ne pripadaju. Dve poslednje strategije odražavaju se i u motivisanom pamćenju: više se pamte informacije u vezi sa svojom grupom, selektivno se pamte pozitivne informacije o svojoj, a negativne o tuđoj grupi, odnosno uvećavaju postignuća svoje a umanjuju postignuća tuđe grupe. U jednom od retkih istraživanja koje je direktno proveravalo ovu pretpostavku (Dutta, 
Kanungo \& Freibergs, 1972) utvrđeno je da su se pozitivni atributi pripisani sopstvenoj grupi pamtili bolje od negativnih; kad je u pitanju bila tuđa grupa, međutim, negativni atributi zapamćeni su bolje od pozitivnih. Autori su ovo interpretirali kao posledicu snage afekata koji se vezuju za atribute (u slučaju sopstvene grupe veći je intenzitet afekta pripisanog pozitivnim nego negativnim atributima; u slučaju tuđe upravo je obrnuto).

Isti je obrazac identifikovan u našem istraživanju: u situaciji slobodnog prisećanja, u proseku je više atributa navedeno za sopstvenu nego za tuđu grupu. Pored toga, odnos pozitivnih naspram ukupnog broja navedenih atributa značajno je povoljniji u slučaju sopstvene naspram tuđe grupe (Tabela 24). Tako je prosečan indeks pozitivnosti za Srbe bio .71, što govori da je više od 70\% navedenih atributa bilo pozitivno. Isti indeks je za Rumune bio .41. Drugim rečima, više od polovine navedenih atributa bilo je negativno. Razliku u tačnosti reprodukcije, međutim, u ovom ogledu nismo dobili.

Moguće je da je uzrok za izostajanje razlike u tačnosti, koju smo dobili u prethodnom ogledu (akter-posmatrač) sledeći: u našim prethodnim ogledima tačnost je u stvari merena preko raspona memorijskih distorzija - što je nečiji izveštaj o postignuću više odudarao od stvarnog postignuća, tretiran je kao manje tačan. U ovom ogledu, međutim, ispitanici se u jednom zadatku slobodno prisećaju atributa, a u drugom se, analogno prethodnim, od njih traži da izveštavaju o postignućima koja su im prethodno saopštena. U procesu slobodnog prisećanja imali su više slobode u rekonstrukciji atributa, pa je tako moguće da veća uključenost, za koju pretpostavljamo da postoji prilikom prisećanja informacija o sopstvenoj grupi, zapravo vodila produkciji većeg broja atributa i većoj mogućnosti greške. 


\section{Povezanost greške preterivanja sa merama psihološke adaptiranosti na poduzorcima prema memorijskoj dostupnosti i javnosti situacije}

(na osnovu rezultata svih ogleda)

Povezanost greške preterivanja sa merama psihološke adaptiranosti na poduzorcima prema javnosti situacije (potrebi za samopredstavljanjem). Kada je reč o povezanosti greške preterivanja sa dispozicionim varijablama koje ukazuju na sliku o sebi, odnosno posredno na psihološku adaptiranost, može se pretpostaviti da će te povezanosti biti različitog intenziteta u zavisnosti od nivoa faktora kojima smo u ogledima manipulisali. Pre svega, moglo bi se očekivati da je povezanost snažnija što je događaj vremenski udaljeniji (Gramzow \& Willard, 2009). Postoji nekoliko razloga za to: memorijske distorzije postaju sve snažnije vremenom, što je potvrđeno i u našem istraživanju. Sećanja nisu samo sve manje tačna, ona su i sve više rekonstrukcija događaja i to takva da se bolje uklapaju u sliku o sebi. Rekonstrukcija događaja odvija se na osnovu naše predstave o sopstvenim sposobnostima, postignućima i osećanjima. Pored toga, moglo se očekivati i da greške preterivanja u nekoliko subtestova budu snažnije povezane što je događaj udaljeniji, s obzirom da se formira jedna opšta slika o događaju i on kao celina smešta u određen kontekst (uspeh/neuspeh, prijatan/neprijatan i slično).

Zbog toga smo sproveli analizu povezanosti greške preterivanja sa akademskim ambicijama, samopoštovanjem, dominantnim raspoloženjem i pozitivnošću autobiografskih sećanja na poduzorcima prema memorijskoj dostupnosti. U prvom ogledu to zapravo znači analiza na poduzorcima studenata prve i treće godine; u drugom i trećem ogledu to je analiza onih koji su testirani neposredno nakon događaja, i odloženo, nakon sedam do deset dana. Značajnost razlika među korelacijama proveravali smo Fišerovim Z-testom, pri čemu smo poredili parove korelacija samo ukoliko je barem jedan koeficijent iz para bio statistički značajan.

Rezultati korelacija na poduzorcima uglavnom potvrđuju početna očekivanja: registrovane povezanosti su snažnije što je događaj udaljeniji u memoriji (Tabele 25, 26, i 27). Najjasnija je ova pravilnost u prvom ogledu, u kome su i registrovane najsnažnije povezanosti greške preterivanja sa dispozicionim varijablama. 


\section{Tabela 25}

Korelacije greške preterivanja sa merama psihološke adaptiranosti, odvojeno za prvu i treću godinu, ogled 1

\begin{tabular}{|c|c|c|c|c|c|c|}
\hline & \multicolumn{2}{|c|}{ Direktan retest (prva godina) } & \multicolumn{2}{|c|}{$\begin{array}{c}\text { Naknadni retest (treća godina) } \\
\text { Naknadni retest }\end{array}$} & \multirow[b]{2}{*}{$\begin{array}{c}\text { Značajnost } \\
\text { razlika među } \\
\text { korelacijama } \\
\text { (prijemni) }\end{array}$} & \multirow[b]{2}{*}{$\begin{array}{c}\text { Značajnost } \\
\text { razlika među } \\
\text { korelacijama } \\
\text { (srednja } \\
\text { škola) }\end{array}$} \\
\hline & $\begin{array}{c}\text { Greška u } \\
\text { izveštavanju } \\
\text { o prijemnom }\end{array}$ & $\begin{array}{c}\text { Zbir } \\
\text { odstupanja za } \\
\text { ukupan prosek } \\
\text { iz srednje } \\
\text { škole }\end{array}$ & $\begin{array}{c}\text { Greška u } \\
\text { izveštavanju } \\
\text { o prijemnom }\end{array}$ & $\begin{array}{l}\text { Zbir odstupanja } \\
\text { za ukupan } \\
\text { prosek iz srednje } \\
\text { škole }\end{array}$ & & \\
\hline & & & & & $\mathrm{Z}$ & $\mathrm{Z}$ \\
\hline Akademske ambicije & $.34(* * *)$ & .20 & $.39(* * *)$ & .12 & 0.3 & \\
\hline Samopoštovanje & -.04 & .09 & -.12 & -.17 & & \\
\hline LOT & $.40(* * *)$ & .04 & $.28(*)$ & .14 & 0.94 & \\
\hline $\begin{array}{l}\text { Dominantno } \\
\text { raspoloženje }\end{array}$ & -.10 & .03 & -.20 & -.05 & & \\
\hline Pozitivnost AB sećanja & $.45(* * *)$ & $.34(* * *)$ & $.72(* * *)$ & $.58(* *)$ & $2.13(* *)$ & $1.49(* *)$ \\
\hline $\begin{array}{l}\text { Greška u izveštavanju } \\
\text { o prijemnom }\end{array}$ & - & .17 & - & $.64(* *)$ & & $2.85(* * *)$ \\
\hline
\end{tabular}

\footnotetext{
Napomena $1 . *$ Korelacija značajna na nivou $0.1 ; * *$ Korelacija značajna na nivou $0.05 ; * * *$ Korelacija značajna
} na nivou 0.01 .

Napomena 2. Značajnost razlika među korelacijama u situaciji direktnog i naknadnog retesta proveravana je samo ukoliko je bar jedna korelacija iz para statistički značajna. 


\section{Tabela 26}

Korelacije greške preterivanja sa merama psihološke adaptiranosti, odvojeno za direktan $i$ naknadan retest, ogled 2

\begin{tabular}{|c|c|c|c|c|c|c|}
\hline & \multicolumn{2}{|c|}{ Direktan retest } & \multicolumn{2}{|c|}{ Naknadni retest } & \multirow[b]{2}{*}{$\begin{array}{c}\text { Značajnost } \\
\text { razlika među } \\
\text { korelacijama } \\
\text { (ukupni skor) }\end{array}$} & \multirow[b]{2}{*}{$\begin{array}{c}\text { Značajnost } \\
\text { razlika među } \\
\text { korelacijama } \\
\text { (svi testovi) }\end{array}$} \\
\hline & $\begin{array}{c}\text { Greška u } \\
\text { izveštavanju } \\
\text { o ukupnom } \\
\text { skoru }\end{array}$ & $\begin{array}{c}\text { Zbir } \\
\text { odstupanja za } \\
\text { sve testove }\end{array}$ & $\begin{array}{c}\text { Greška u } \\
\text { izveštavanju } \\
\text { o ukupnom } \\
\text { skoru }\end{array}$ & $\begin{array}{c}\text { Zbir } \\
\text { odstupanja } \\
\text { za sve } \\
\text { testove }\end{array}$ & & \\
\hline & & & & & $\mathrm{Z}$ & $\mathrm{Z}$ \\
\hline Akademske ambicije & -.16 & -.04 & .16 & $.23(* *)$ & & $1.49(* *)$ \\
\hline Samopoštovanje & .14 & .09 & -.12 & -.08 & & \\
\hline LOT & .13 & .04 & .23 & $.22(*)$ & & 1.04 \\
\hline $\begin{array}{l}\text { Dominantno } \\
\text { raspoloženje }\end{array}$ & .05 & .06 & .08 & .08 & & \\
\hline Pozitivnost AB sećanja & .05 & $.23(*)$ & $.31(* *)$ & $.27(* *)$ & $1.50(* *)$ & 0.25 \\
\hline $\begin{array}{l}\text { Greška u izveštavanju o } \\
\text { ukupnom skoru }\end{array}$ & - & $.75(* * *)$ & - & $.91(* * *)$ & & $3.1(* * *)$ \\
\hline
\end{tabular}

Napomena $1 .{ }^{*}$ Korelacija značajna na nivou $0.1 ; * *$ Korelacija značajna na nivou $0.05 ; * * *$ Korelacija značajna na nivou 0.01 .

Napomena 2. Značajnost razlika među korelacijama u situaciji direktnog i naknadnog retesta proveravana je samo ukoliko je bar jedna korelacija iz para statistički značajna 
Tabela 27

Korelacije greške preterivanja sa merama psihološke adaptiranosti, odvojeno za direktan $i$ naknadan retest, ogled 3

\begin{tabular}{|c|c|c|c|c|c|c|}
\hline & \multicolumn{2}{|c|}{ Direktan retest } & \multicolumn{2}{|c|}{ Naknadni retest } & \multirow[b]{2}{*}{$\begin{array}{c}\text { Značajnost } \\
\text { razlika među } \\
\text { korelacijama } \\
\text { (ukupni skor) }\end{array}$} & \multirow[b]{2}{*}{$\begin{array}{r}\text { Značajnost } \\
\text { razlika među } \\
\text { korelacijama } \\
\text { (svi testovi) }\end{array}$} \\
\hline & $\begin{array}{c}\text { Greška u } \\
\text { izveštavanju } \\
\text { o ukupnom } \\
\text { skoru }\end{array}$ & $\begin{array}{c}\text { Zbir } \\
\text { odstupanja } \\
\text { za sve } \\
\text { testove }\end{array}$ & $\begin{array}{c}\text { Greška u } \\
\text { izveštavanju o } \\
\text { ukupnom skoru }\end{array}$ & $\begin{array}{c}\text { Zbir } \\
\text { odstupanja } \\
\text { za sve } \\
\text { testove }\end{array}$ & & \\
\hline & & & & & $\mathrm{Z}$ & $\mathrm{Z}$ \\
\hline Akademske ambicije & .14 & .21 & .10 & .02 & & \\
\hline Samopoštovanje & .15 & .09 & -.02 & .01 & & \\
\hline LOT & .17 & .11 & -.04 & -.14 & & \\
\hline $\begin{array}{l}\text { Dominantno } \\
\text { raspoloženje }\end{array}$ & -.07 & -.09 & .06 & .06 & & \\
\hline $\begin{array}{l}\text { Pozitivnost } \mathrm{AB} \\
\text { sećanja }\end{array}$ & .06 & .02 & $.20(*)$ & $.19(*)$ & 0.9 & 1.1 \\
\hline $\begin{array}{l}\text { Greška u izveštavanju } \\
\text { o ukupnom skoru }\end{array}$ & - & $.642(* * *)$ & - & $.76(* * *)$ & & $1.38(*)$ \\
\hline
\end{tabular}

Napomena 1. *Korelacija značajna na nivou .01; ** Korelacija značajna na nivou .05; ***Korelacija značajna na nivou .001

Napomena 2. Značajnost razlika među korelacijama u situaciji direktnog i naknadnog retesta proveravana je samo ukoliko je bar jedna korelacija iz para statistički značajna

Povezanost greške preterivanja sa merama psihološke adaptiranosti na poduzorcima prema javnosti situacije (potrebi za samopredstavljanjem). Ukoliko smatramo da je sklonost ka preterivanju adaptivna, mogli bismo očekivati i da je veza sa dispozicionim varijablama snažnija ukoliko se o postignuću izveštava u privatnoj, nego u javnoj situaciji (Willard \& Gramzow, 2003). Naime, nivo preuveličavanja sopstvenih postignuća trebalo bi da se bolje uklopi u sliku o sebi ukoliko je do preuveličavanja došlo ne usled tendencije ka samoprikazivanju, već usled želje da očuvamo koherentnu i pozitivnu sliku o sebi. Dakle ne $\mathrm{u}$ javnoj već u privatnoj situaciji. Na isti način kao u prethodnom bloku, proverili smo povezanosti greške preterivanja i dispozicionih varijabli na poduzorcima ispitanika koji su pismeno i usmeno testirani. Rezultati ne daju jasnu sliku o tome kako javnost situacije deluje na ovu povezanost. Iako je u pismenom retestu više značajnih korelacija, i one su češće većeg intenziteta, postoje i situacije u kojima važi obrnuto. U trećem ogledu na poduzorcima nije bilo značajnih povezanosti, tako da proveravanje razlika među njima nije bilo moguće. Čini se da je za sistematsku proveru ove hipoteze trebalo konstruisati niz ogleda u kojima ispitanici u ekološki validnim situacijama testiranja dobijaju fidbek o 
postignuću koje je značajno za sliku o sebi (ili iskoristiti već postojeće podatke o postignućima, na primer na studijama) a zatim na dovoljno velikom uzorku proveravati uticaj javnosti situacije saopštavanja.

Tabela 28

Korelacije greške preterivanja sa merama psihološke adaptiranosti, odvojeno za usmeni ili pismeni retest, ogled 2

\begin{tabular}{|c|c|c|c|c|c|c|}
\hline & \multicolumn{2}{|c|}{ Usmeni retest } & \multicolumn{2}{|c|}{ Pismeni retest } & \multirow[b]{2}{*}{$\begin{array}{c}\text { Značajnost } \\
\text { razlika među } \\
\text { korelacijama } \\
\text { (ukupni skor) }\end{array}$} & \multirow[b]{2}{*}{$\begin{array}{c}\text { Značajnost } \\
\text { razlika među } \\
\text { korelacijama } \\
\text { (svi testovi) }\end{array}$} \\
\hline & $\begin{array}{c}\text { Greška u } \\
\text { izveštavanju } \\
\text { o ukupnom } \\
\text { skoru }\end{array}$ & $\begin{array}{c}\text { Zbir } \\
\text { odstupanja } \\
\text { za sve } \\
\text { testove }\end{array}$ & $\begin{array}{c}\text { Greška u } \\
\text { izveštavanju } \\
\text { o ukupnom } \\
\text { skoru }\end{array}$ & $\begin{array}{c}\text { Zbir } \\
\text { odstupanja } \\
\text { za sve } \\
\text { testove }\end{array}$ & & \\
\hline & & & & & $\mathrm{Z}$ & $\mathrm{Z}$ \\
\hline Akademske ambicije & -.02 & .03 & .11 & $.21(*)$ & & 0.55 \\
\hline Samopoštovanje & -.01 & .01 & .09 & .06 & & \\
\hline LOT & .12 & .11 & $.27(* *)$ & $.22(*)$ & 0.85 & 0.6 \\
\hline $\begin{array}{l}\text { Dominantno } \\
\text { raspoloženje }\end{array}$ & .15 & .14 & -.10 & -.07 & & \\
\hline Pozitivnost $\mathrm{AB}$ sećanja & .09 & .19 & $.32(* * *)$ & $.33(* * *)$ & $1.35(*)$ & $1.13(*)$ \\
\hline $\begin{array}{l}\text { Greška u izveštavanju o } \\
\text { ukupnom skoru }\end{array}$ & - & $.93(* *)$ & - & $.83(* *)$ & & $2.68(* * *)$ \\
\hline
\end{tabular}

Napomena $1 . *$ Korelacija značajna na nivou $0.1 ; * *$ Korelacija značajna na nivou $0.05 ; * * *$ Korelacija značajna na nivou 0.01 .

Napomena 2. Značajnost razlika među korelacijama u situaciji direktnog i naknadnog retesta proveravana je samo ukoliko je bar jedna korelacija iz para statistički značajna. 


\section{Tabela 29}

Korelacije greške preterivanja sa merama psihološke adaptiranosti, odvojeno za usmeni ili pismeni retest, ogled 3

\begin{tabular}{|c|c|c|c|c|c|c|}
\hline & \multicolumn{2}{|c|}{ Usmeni retest } & \multicolumn{2}{|c|}{ Pismeni retest } & \multirow{4}{*}{$\begin{array}{l}\text { Značajnost } \\
\text { razlika među } \\
\text { korelacijama } \\
\text { (ukupni skor) }\end{array}$} & \multirow{4}{*}{$\begin{array}{c}\text { Značajnost } \\
\text { razlika među } \\
\text { korelacijama } \\
\text { (svi testovi) }\end{array}$} \\
\hline & $\begin{array}{c}\text { Greška u } \\
\text { izveštavanju }\end{array}$ & $\begin{array}{c}\text { Zbir } \\
\text { odstupanja }\end{array}$ & $\begin{array}{c}\text { Greška u } \\
\text { izveštavanju }\end{array}$ & $\begin{array}{c}\text { Zbir } \\
\text { odstupanja }\end{array}$ & & \\
\hline & o ukupnom & za sve & o ukupnom & za sve & & \\
\hline & skoru & testove & skoru & testove & & \\
\hline & & & & & $\mathrm{Z}$ & $\mathrm{Z}$ \\
\hline Akademske ambicije & .10 & .06 & .05 & .10 & & \\
\hline Samopoštovanje & .03 & .07 & .15 & .08 & & \\
\hline LOT & .08 & .02 & .07 & -.02 & & \\
\hline $\begin{array}{l}\text { Dominantno } \\
\text { raspoloženje }\end{array}$ & .01 & -.03 & -.03 & .00 & & \\
\hline Pozitivnost AB sećanja & -.07 & -.07 & -.16 & -.16 & & \\
\hline $\begin{array}{l}\text { Greška u izveštavanju o } \\
\text { ukupnom skoru }\end{array}$ & - & $.750(* * *)$ & - & $.727(* * *)$ & & 0.31 \\
\hline
\end{tabular}

Napomena 1. *Korelacija značajna na nivou $0.1 ; * *$ Korelacija značajna na nivou $0.05 ; * * *$ Korelacija značajna na nivou 0.01 .

Napomena 2. Značajnost razlika među korelacijama u situaciji direktnog i naknadnog retesta proveravana je samo ukoliko je bar jedna korelacija iz para statistički značajna. 


\section{Postoji li sklonost ka pozitivnoj samoevaluaciji?}

\section{(na osnovu rezultata svih ogleda)}

Naše istraživanje je osmišljeno tako da proveri još jednu značajnu hipotezu koja se odnosi na tendencije ljudi prilikom samoprocene, odnosno njene dve podhipoteze: prvo, da su ljudi prilikom samoprocene skloni da sebe pozicioniraju bliže pozitivnim polovima atributa procene (Brown, 1989; Baumeister, Tice \& Hutton, 1989; Sedikides et al., 2003; Sedikides \& Gregg, 2008) i drugo, da postoji veza između procena na različitim dimenzijama, odnosno "sindrom pozitivne samoevaluacije". Drugim rečima, da pozitivna samoprocena na jednoj dimenziji povećava verovatnoću pozitivne samoprocene na drugim, nezavisnim dimenzijama. Dimenzije o kojima je reč mogu biti veoma udaljene jedna od druge (jedna može biti mera sposobnosti, druga dominantnog afekta, na primer), tako da povezanost među njima nije na prvi pogled očekivana (Lucas, Diener \& Sub, 1996 ${ }^{25}$; Oishi \& Diener, 2001).

U našoj seriji ogleda kod svih ispitanika registrovani su: nivo samopoštovanja, kao evaluativna dimenzija slike o sebi, učestalost različitih pozitivnih-negativnih osećanja, kao procena dominantnog afektivnog tona, opšta životna orijentacija, odnosno mera optimizma i akademske ambicije kao mera motiva za postignućem. Postoji niz prethodnih istraživanja koja ukazuju na to da se ljudi na ovim dimenzijama pozitivno samoocenjuju. Navešćemo samo najrelevantnija za sve četiri mere.

Baumajster je sa saradnicima (Baumeister et al., 1989) utvrdio da se samopoštovanje, nezavisno od uzorka i instrumenata kojima se meri, distribuira tako da su prosečne empirijske vrednosti uvek više od teorijskih sredina skale. U opsežnom istraživanju sprovedenom u 53 zemlje na pet kontinenata (Schmidt \& Allik, 2005) ova tendencija je potvrđena na celokupnom uzorku, ali i na svakom pojedinačnom nacionalnom uzorku, uključujući i kolektivističke kulture poput Japana, u kojima se mogla očekivati suprotna tendencija, s obzirom na dominirajuće društvene norme neisticanja i skromnosti. Pored toga, visok stepen samopoštovanja registrovan je i na demografski različitim poduzorcima: ženama i muškarcima, ispitanicima različitog imovinskog, obrazovnog i profesionalnog statusa, kao i različitim uzrasnim grupama (mada sa vrhuncem u adolescenciji).

\footnotetext{
${ }^{25}$ Iako je cilj ovog konkretnog istraživanja bio da pokaže da svaka od mera blagostanja ipak ima zadovoljavajuću diskriminativnu validnost, za ovu diskusiju je od značaja da ipak dele značajan procenat varijanse da se može govoriti o opštem odnosu prema sebi
} 
U istraživanju sličnog obima, Diner i Diner (Diener \& Diener, 1996) registrovali su da li se ljudi osećaju srećno i da li je njihovo dominantno osećanje bliže prijatnom ili neprijatnom polu kontinuuma. U 38 od 43 zemlje (uz izuzetak nekoliko veoma siromašnih i politički nestabilnih zemalja) prosečan osećaj sreće je bio značajno veći od teorijske sredine skale, a indeks dominantnog osećanja ukazivao je na pozitivnost. Opšte pozitivno osećanje registrovano je i u različitim "ranjivim grupama", kao što su ljudi sa fizičkim hendikepom, nezaposleni ili veoma stari.

Nivo akademskih ambicija koji je meren u našem istraživanju odabran je kao reprezent motiva postignuća. S obzirom da su uzorak činili isključivo srednjoškolci i aktivni studenti, očekivali smo da akademsko postignuće bude primarno za sliku o sebi kod većine ispitanika i da registrovan nivo akademskih ambicija bude iznad proseka skale. Slični rezultati dobijeni su na različitim uzorcima đaka i studenata u SAD, u istraživanju u kome je korišćena višedimenzionalna skala akademske motivacije (Vallerand et al., 1992).

Životni optimizam je odabran kao mera očekivanja u odnosu na budućnost, i kao predstavnik grupe temporalnih pristrasnosti. U našem istraživanju meren je skalom u kojoj ajtemi registruju opšte tendencije (npr. "Sve u svemu, očekujem da će mi se lepe stvari desiti pre nego loše"). Istraživanja koja su koristila ovu skalu (vidi metaanalizu Anderson, 1986) ali i istraživanja u kojima su se očekivanja od budućnosti merila na drugačije načine, na primer procenjivanjem verovatnoće da će se ispitaniku desiti pozitivne odnosno negativne stvari $u$ daljem životu (Weinstein, 1980), došla su do sličnih rezultata: ljudi su većinom preterano optimistični u odnosu na budućnost i očekuju da budu srećniji od prosečne osobe.

Rezultati našeg istraživanja potvrđuju obe tendencije: na sve četiri mere odnosa prema sebi, ispitanici su u proseku davali odgovore značajno različite od teorijske sredine skale; samoprocene na svim merama značajno su međusobno povezane.

Skala dominantnog raspoloženja i indeks pozitivnosti autobiografskih sećanja imaju apsolutnu nulu (dominantno raspoloženje procenjivano je skalom sa dva opozitna pola i srednjom neutralnom vrednošću, indeks pozitivnosti sećanja zapravo predstavlja procenat navedenih sećanja), dok su Rozenbergova skala samopoštovanja, LOT skala i Skala akademskih ambicija klasične sumacione skale, sa svojim inherentnim ograničenjima od kojih je najvažnije da nemaju apsolutnu nulu. To znači da se do srednje prosečne vrednosti može stići putem različitih strategija (na primer, zaokruživanjem srednje vrednosti, ali i zaokruživanjem ekstremnih vrednosti na ponuđenim skalama). Neki metodolozi međutim, sugerišu da, ukoliko 
se potkrepe distribucijama odgovora na pojedinačnim tvrdnjama, i u ovom slučaju ima smisla analizirati značajnost razlike empirijskih i teorijskih proseka u odgovorima na skali (Harter, 1997). Pri ovakvoj analizi mora se uzeti u obzir smisao (sadržaj) svake pojedinačne tvrdnje i njihova pretpostavljena ekstremnost (intenzitet).

Empirijski prosek skale samopoštovanja se značajno razlikuje od teorijskog (25), i "pomeren" je ka pozitivnijem viđenju sebe, odnosno višem samopoštovanju $(t(557)=38.029, p=.000)$ (Grafikon 42). Distribucija odgovora na svim tvrdnjama potkrepljuje ovaj zaključak (Tabela 30).

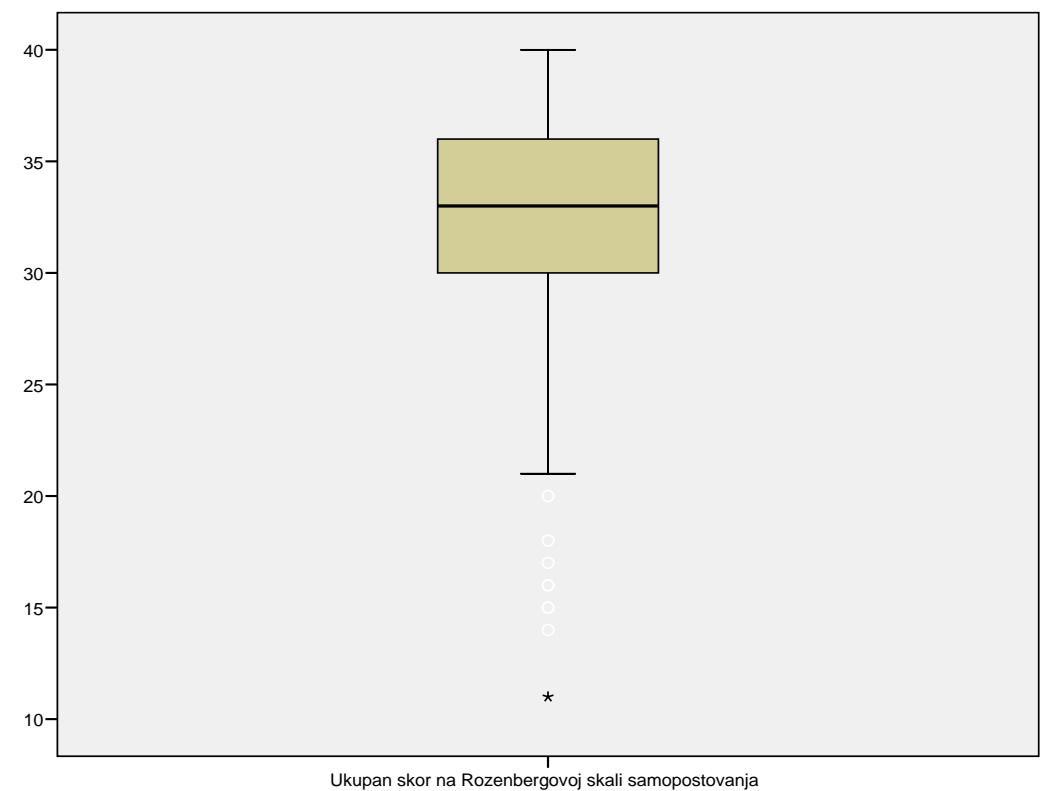

Grafikon 42. Distribucija ukupnog skora na skali samopoštovanja.

Tabela 30

Procenat prihvatanja pojedinačnih tvrdnji na skali samopoštovanja

\begin{tabular}{|c|c|c|c|c|c|c|}
\hline & \multicolumn{4}{|c|}{ Procenat prihvatanja tvrdnje } & \multirow[t]{2}{*}{$\mathrm{M}$} & \multirow[t]{2}{*}{ SD } \\
\hline & 1 & 2 & 3 & 4 & & \\
\hline Uopšteno govoreci, zadovoljan/na sam sobom. & 1.8 & 12.2 & 53.6 & 32.3 & 3.17 & 0.72 \\
\hline Želeo/la bih da imam više samopoštovanja.* & 24.2 & 29.4 & 27.8 & 18.6 & 2.41 & 1.05 \\
\hline $\begin{array}{l}\text { Osecam da ima puno toga čime bih se mogao/la } \\
\text { ponositi. }\end{array}$ & 0.9 & 12.9 & 52.2 & 34.1 & 3.19 & 0.68 \\
\hline Ponekad se osećam potpuno beskorisno.* & 38.0 & 37.6 & 15.8 & 8.6 & 1.95 & 0.94 \\
\hline $\begin{array}{l}\text { Sposoban/na sam da radim i izvršavam zadatke } \\
\text { jednako uspešno kao i većina drugih. }\end{array}$ & 2.5 & 3.0 & 34.1 & 60.4 & 3.52 & 0.68 \\
\hline S vremena na vreme osećam da ništa ne vredim.* & 52.5 & 29.2 & 12.2 & 6.1 & 1.72 & 0.90 \\
\hline Osećam da posedujem niz vrednih osobina. & 1.8 & 5.0 & 45.3 & 47.8 & 3.39 & 0.67 \\
\hline Ukupan skor & & & & & 32.72 & 4.80 \\
\hline
\end{tabular}


Prosečna procena dominirajućeg raspoloženja značajno odstupa od teorijskog proseka skale (40), i to u pravcu pozitivnijeg raspoloženja $((t(556)=-20.301, p=.000)$ (Grafikon 43 i Tabela 31).

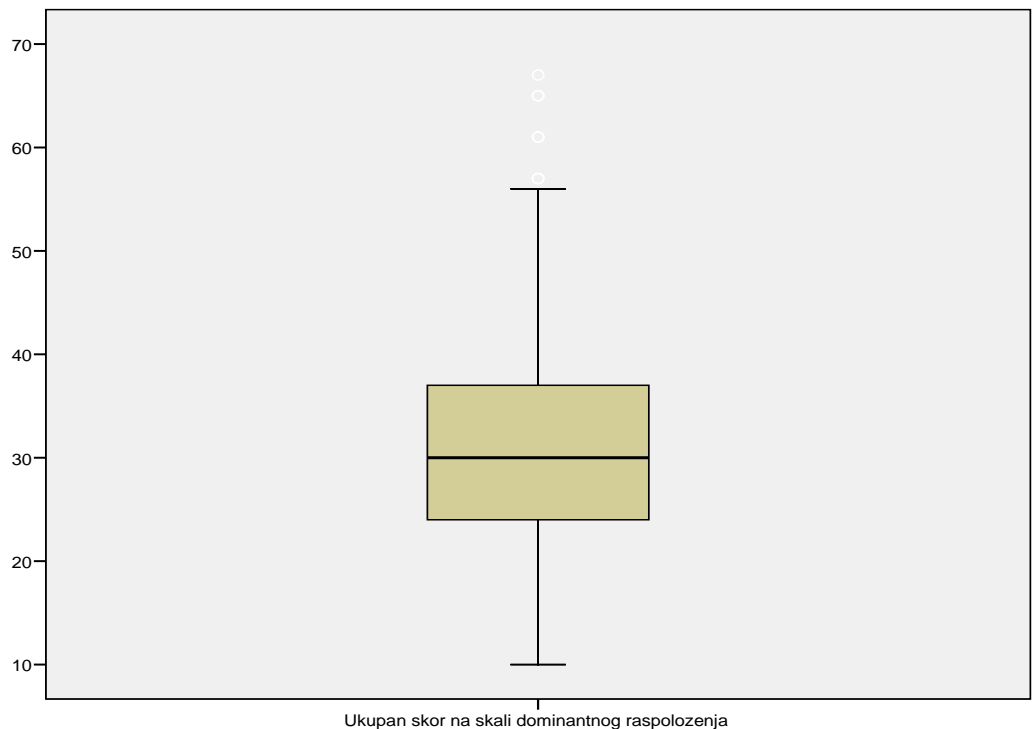

Grafikon 43. Distribucija ukupnog skora na skali dominantnog raspoloženja.

\section{Tabela 31}

Procenat prihvatanja pojedinačnih tvrdnji na skali dominantnog raspoloženja

\begin{tabular}{|c|c|c|c|c|c|c|c|c|c|}
\hline & \multicolumn{7}{|c|}{ Procenat prihvatanja } & \multirow[t]{2}{*}{ M } & \multirow[t]{2}{*}{$\mathrm{SD}$} \\
\hline & 1 & 2 & 3 & 4 & 5 & 6 & 7 & & \\
\hline Odmorno & 2.9 & 14.2 & 22.4 & 19.0 & 31.2 & 9 & 1.4 & 3.94 & 1.36 \\
\hline Srećno & 9.3 & 30.8 & 25.8 & 18.6 & 10.4 & 4.7 & 0.4 & 3.05 & 1.33 \\
\hline Uspešno & 4.3 & 23.7 & 32.6 & 21.7 & 12.7 & 4.1 & 0.9 & 3.31 & 1.25 \\
\hline Moćno & 3.9 & 15.4 & 26.9 & 31.2 & 15.2 & 5.9 & 1.4 & 3.62 & 1.27 \\
\hline Voljeno & 27.1 & 28.0 & 18.6 & 10.6 & 9.7 & 3.8 & 2.3 & 2.68 & 1.57 \\
\hline Zaštićeno & 27.2 & 25.6 & 18.1 & 14.3 & 8.1 & 4.1 & 2.5 & 2.73 & 1.59 \\
\hline Energično & 14.5 & 19.6 & 23.9 & 20.6 & 14.4 & 5.2 & 1.8 & 3.24 & 1.50 \\
\hline Veselo & 15.2 & 30.1 & 23.7 & 17.2 & 7.7 & 4.7 & 1.4 & 2.92 & 1.43 \\
\hline Optimistično & 20.4 & 25.4 & 20.6 & 17.2 & 7.9 & 5.4 & 3.0 & 2.95 & 1.59 \\
\hline Vedro & 15.9 & 28.5 & 25.4 & 16.3 & 8.2 & 3.4 & 2.2 & 2.91 & 1.44 \\
\hline Ukupan skor & & & & - & & & & 31.36 & 10.05 \\
\hline
\end{tabular}

Napomena: Niži skor znači pozitivnije opšte raspoloženje 
Odstupanje empirijskog od teorijskog proseka skale akademskih ambicija (10) značajno je, i to u smeru pozitivnije procene $(t(557)=22.272, p=.000)$ (Grafikon 44, Tabela 32).

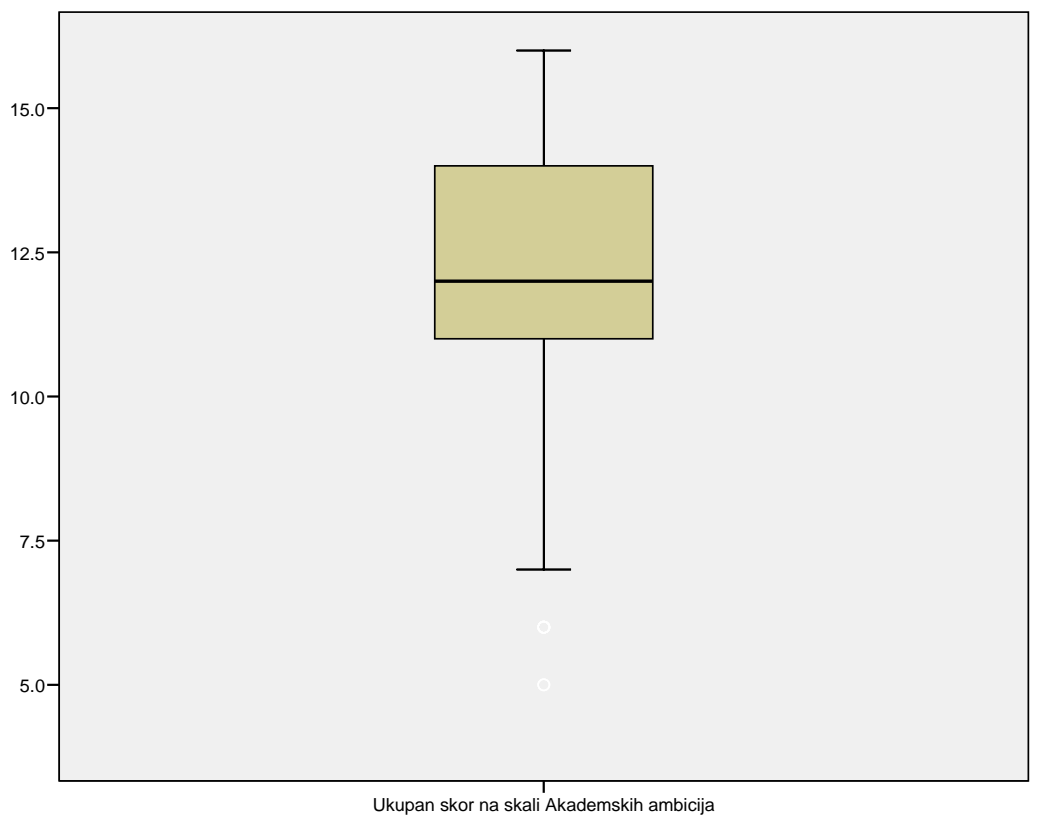

Grafikon 44. Distribucija ukupnog skora na skali akademskih ambicija.

Tabela 32

Procenat prihvatanja pojedinačnih tvrdnji na skali akademskih ambicija

\begin{tabular}{|c|c|c|c|c|c|c|}
\hline & \multicolumn{4}{|c|}{ Procenat prihvatanja tvrdnje } & \multirow[t]{2}{*}{$\mathrm{M}$} & \multirow[t]{2}{*}{$\mathrm{SD}$} \\
\hline & 1 & 2 & 3 & 4 & & \\
\hline \multicolumn{7}{|l|}{ Stalo mi je do toga da imam dobre ocene na } \\
\hline studijama. & 2.0 & 7.0 & 34.4 & 56.6 & 3.46 & 0.71 \\
\hline \multicolumn{7}{|l|}{ Ne mogu sebe da zamislim da poništavam ispitnu } \\
\hline ocenu.* & 28.9 & 26.7 & 24.2 & 20.3 & 2.36 & 1.10 \\
\hline \multicolumn{7}{|l|}{ Imam razumevanja za ljude koji se žale ako nisu } \\
\hline zadovoljni ocenom. & 3.8 & 16.3 & 38.2 & 41.8 & 3.18 & 0.84 \\
\hline Dajem sve od sebe da budem odlican student. & 7.9 & 22.6 & 38.4 & 31.2 & 2.93 & 0.92 \\
\hline Ukupan skor & \multicolumn{4}{|c|}{-} & 12.21 & 2.34 \\
\hline
\end{tabular}


I na skali opšte životne orijentacije, empirijski utvrđen optimizam pozitivno odstupa od teorijskog proseka skale (15) $(t(557)=21.28, p=.000)($ Grafikon 45, Tabela 33).

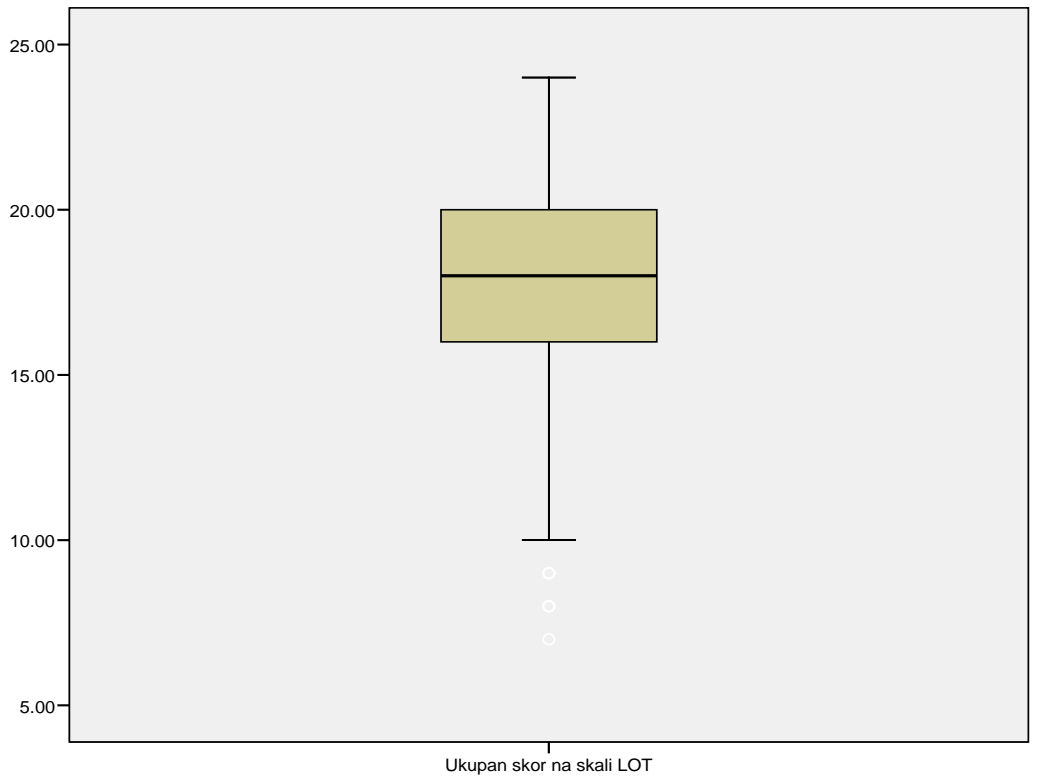

Grafikon 45. Distribucija ukupnog skora na skali životnog optimizma.

Tabela 33

Procenat prihvatanja pojedinačnih tvrdnji na skali životnog optimizma

\begin{tabular}{|c|c|c|c|c|c|c|}
\hline & \multicolumn{4}{|c|}{ Procenat prihvatanja tvrdnje } & \multirow[t]{2}{*}{ M } & \multirow[t]{2}{*}{ SD } \\
\hline & 1 & 2 & 3 & 4 & & \\
\hline \multicolumn{7}{|l|}{ U neizvesnim vremenima obično očekujem } \\
\hline najbolje. & 5.0 & 24.0 & 52.3 & 18.6 & 2.85 & 0.78 \\
\hline \multicolumn{7}{|l|}{ Ako postoji mogucnost da mi se nešto loše desi, } \\
\hline sigurno će se i desiti.* & 25.4 & 49.1 & 18.8 & 6.6 & 2.07 & 0.84 \\
\hline \multicolumn{7}{|l|}{ Uvek sam optimističan/na kada je moja budućnost u } \\
\hline pitanju. & 2.7 & 18.1 & 48.6 & 30.6 & 3.07 & 0.77 \\
\hline \multicolumn{7}{|l|}{ Gotovo nikada ne očekujem da će mi stvari "ići na } \\
\hline ruku".* & 19.4 & 36.9 & 24.7 & 18.2 & 2.52 & 1.17 \\
\hline Retko računam na to da će mi se lepe stvari desiti.* & 36.9 & 41.8 & 17.0 & 4.3 & 1.89 & 0.84 \\
\hline \multicolumn{7}{|l|}{ Na kraju krajeva, očekujem da će mi se dobre stvari } \\
\hline desiti pre nego loše. & 2.5 & 12.5 & 41.2 & 43.9 & 3.33 & 0.87 \\
\hline Ukupan skor & & & & & 18.01 & 3.34 \\
\hline
\end{tabular}


Iako su ispitanici imali mogućnost da autobiografska sećanja po valenci svrstaju u tri kategorije (uključujući i neutralna), testirali smo da li je utvrđen procenat pozitivnih značajno različit od 50\%. I prema ovom, strožem kriterijumu, indeks pozitivnosti se značajno razlikovao od $0.5(t(546)=19.05, p=.000)($ Grafikon 46$)$.

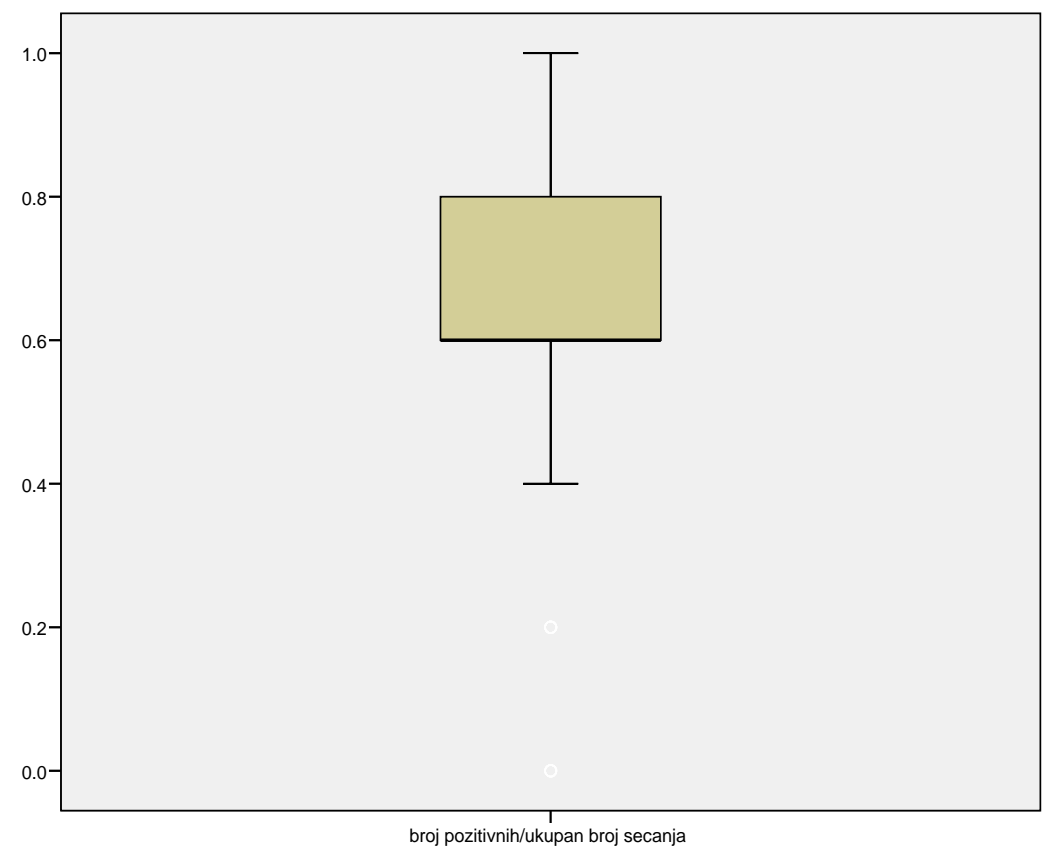

Grafikon 46. Distribucija indeksa pozitivnosti autobiografskih sećanja.

Sve mere samoopažanja međusobno su značajno povezane, i to na očekivan način: pozitivnija samoprocena na jednoj dimenziji uslovljava pozitivniju samoprocenu na drugim. Najsnažnije su povezani dominantno raspoloženje, samopoštovanje i opšti životni optimizam (korelacije su blizu .5), ali je i pozitivnost spontano evociranih autobiografskih sećanja značajno povezana sa sve četiri mere samoopažanja, uključujući, na primer, i nivo akademskih ambicija. 
Tabela 34

Matrica korelacija različitih mera samoopažanja

\begin{tabular}{|c|c|c|c|c|c|}
\hline & $\begin{array}{c}\text { Broj } \\
\text { pozitivnih } \\
\text { /ukupan } \\
\text { broj } \\
\text { secanja }\end{array}$ & $\begin{array}{c}\text { Ukupan } \\
\text { skor na } \\
\text { Rozenberg } \\
\text { ovoj skali }\end{array}$ & $\begin{array}{c}\text { Ukupan skor } \\
\text { na skali } \\
\text { Akademskih } \\
\text { ambicija }\end{array}$ & $\begin{array}{l}\text { Ukupan } \\
\text { skor na } \\
\text { skali LOT }\end{array}$ & $\begin{array}{l}\text { Ukupan skor na } \\
\text { skali } \\
\text { dominantnog } \\
\text { raspolozenja }\end{array}$ \\
\hline $\begin{array}{l}\text { Broj pozitivnih/ukupan broj } \\
\text { secanja }\end{array}$ & -- & & & & \\
\hline $\begin{array}{l}\text { Ukupan skor na Rozenbergovoj } \\
\text { skali samopoštovanja }\end{array}$ & $.19(* *)$ & -- & & & \\
\hline $\begin{array}{l}\text { Ukupan skor na skali } \\
\text { Akademskih ambicija }\end{array}$ & $.12(* *)$ & $.15(* *)$ & -- & & \\
\hline Ukupan skor na skali LOT & $.25(* *)$ & $.50(* *)$ & $.19(* *)$ & -- & \\
\hline $\begin{array}{l}\text { Ukupan skor na skali } \\
\text { dominantnog raspolozenja }\end{array}$ & $-.20(* *)$ & $-.50(* *)$ & $-.14(* *)$ & $-.48(* *)$ & -- \\
\hline
\end{tabular}

S obzirom da su merene dispozicije do te mere različite, $i$ da su merene su na različite načine, ovaj nalaz dozvoljava da zaključimo da postoji sklonost ka pozitivnom viđenju sebe na različitim dimenzijama, odnosno pozitivna procena različitih psiholoških resursa kojima pojedinac raspolaže.

Mere pozitivne distorzije $\mathrm{u}$ izveštavanju o sopstvenim postignućima dobijena $\mathrm{u}$ našem istraživanju na seriji testova specifičnog sadržaja u većini analiza bila je u pozitivnoj, iako ne substancijalnoj korelaciji sa različitim merama dobre adaptiranosti, što ukazuje na to da je bilo osnove pretpostaviti da je ova vrsta memorijske greške karakteristična za ljude koji sebe povoljno procenjuju i na drugim dimenzijama. Ne može se, međutim, reći da naši nalazi u potpunosti potkrepljuju ovu pretpostavku. 


\section{Opšta diskusija}

Pre nego što pokušamo da sintetišemo nalaze svih ogleda, daćemo i njihovu metodološku sintezu, odnosno podsetićemo početnih pretpostavki i načina na koji smo operacionalizovali nezavisne i zavisne varijable.

U Tabeli 35 dat je pregled osnovnih faktora koje smo varirali u eksperimentima i očekivanja o njihovom dejstvu.

Tabela 35

Operacionalizacija nezavisnih varijabli u ogledima (pregled)

\begin{tabular}{|c|c|c|c|c|}
\hline & $\begin{array}{c}\text { Memorijska } \\
\text { dostupnost }\end{array}$ & Uključenost & $\begin{array}{l}\text { Motivacija: tačnost } \\
\text { ili } \\
\text { samopredstavljanje }\end{array}$ & $\begin{array}{c}\text { Uspešnost u } \\
\text { zadatku }\end{array}$ \\
\hline Eksperiment 1 & $\begin{array}{l}\text { Studenti prve i } \\
\text { treće godine }\end{array}$ & -- & $\begin{array}{l}\text { Instrukcija: što } \\
\text { tačnije ili bez } \\
\text { specifikacije }\end{array}$ & \\
\hline Eksperiment 2 & $\begin{array}{c}\text { Neposredno } \\
\text { retestiranje i } \\
\text { nakon 7-10 dana }\end{array}$ & $\begin{array}{c}\text { Sadržaj testa: } \\
\text { vizuelna } \\
\text { percepcija ili } \\
\text { opšta kognitivna } \\
\text { sposobnost }\end{array}$ & $\begin{array}{c}\text { Javno ili privatno } \\
\text { saopštavanje } \\
\text { rezultata }\end{array}$ & \\
\hline Eksperiment 3 & $\begin{array}{c}\text { Neposredno } \\
\text { retestiranje i } \\
\text { nakon 7-10 dana }\end{array}$ & -- & $\begin{array}{c}\text { Javno ili privatno } \\
\text { saopštavanje } \\
\text { rezultata }\end{array}$ & $\begin{array}{c}\text { Fidbek o } \\
\text { uspehu/neuspehu }\end{array}$ \\
\hline
\end{tabular}

Eksperiment 4.1

Eksperiment 4.2

Eksperiment 5

\section{Akter ili}

posmatrač

Akter ili

posmatrač

Svoja ili tudja

grupa

Napomena. Masnim slovima su označene eksperimentalne situacije u kojima smo očekivali izraženiju grešku preterivanja.

Grešku preterivanja definisali smo kao razliku između postignuća o kome ispitanik izveštava i stvarnog postignuća (saopštenog ispitaniku). U većini ogleda, ispitanici nisu izveštavali o 
jednom, već o nekoliko rezultata (prosek iz sve četiri godine srednje škole, prijemni ispit ili postignuća na subtestovima i ukupnom testu). Tabela 36 daje pregled načina na koji je greška preterivanja operacionalizovana u svih šest ogleda.

Tabela 36

Operacionalizacija glavnih zavisnih varijabli u ogledima (pregled)

\begin{tabular}{ll}
\hline Eksperiment 1 & $\begin{array}{l}\text { Razlika između upamćenih i tačnih podataka o prosečnim ocenama tokom } 4 \text { godine } \\
\text { srednje škole i broju poena na prijemnom }\end{array}$ \\
Eksperiment 2 & $\begin{array}{l}\text { Razlika između upamćenih i tačnih podataka o skoru (u percentilima) na tri subtesta i } \\
\text { ukupnom skoru na testu }\end{array}$ \\
Eksperiment 3 & $\begin{array}{l}\text { Razlika između upamćenih i tačnih podataka o skoru (u percentilima) na tri subtesta i } \\
\text { ukupnom skoru na testu } \\
\text { Rksperiment 4.1 }\end{array}$ \\
nazlika između procene broja tačnih odgovora i registrovanog broja tačnih odgovora \\
nksperiment 4.2
\end{tabular}$\quad \begin{aligned} & \text { Razlika između upamćenog skora na testu i registrovanog skora na testu } \\
& \text { Broj upamćenih atributa za svoju i tuđu grupu, tačnost i pozitivnost upamćenih } \\
& \text { atributa za svoju ili tuđu grupu } \\
& \text { Razlika upamćenih i tačnih podataka o skoru na } 5 \text { subtestova i testu sposobnosti }\end{aligned}$

Da li rezultati ukazuju na doslednosti u efektima, odnosno na izvesne zakonitosti u pamćenju sopstvenih postignuća?

Svi osnovni rezultati ogleda sumirani su u Tabeli 37. Pre svega, greška preterivanja bila je značajno veća što je događaj o kome je reč bio vremenski udaljeniji: memorijska dostupnost pokazala se kao najznačajniji faktor koji doprinosi iskrivljavanju sopstvenih postignuća. U meta-analizi koja je uključila preko 100 istraživanja, udaljenost događaja u pamćenju pokazala se kao najznačajniji prediktor pozitivne pristrasnosti u pamćenju (Matlin \& Stang, 1978). Naši rezultati potvrđuju ovu pravilnost.

Javnost situacije nije proizvodila značajne efekte u svim eksperimentima, iako je razlika uvek bila u očekivanom smeru: ukoliko se o rezultatima izveštavalo u usmenom intervjuu, odnosno u kontekstu koji bi trebalo da provocira potrebu za samopredstavljanjem, greška preterivanja bila je izraženija nego ukoliko se o rezultatima izveštavalo pismeno i anonimno. Uključenost, koja je u seriji izvedenih ogleda operacionalizovana na različite načine, proizvodila je različito značajne efekte: kada se involviranošću manipulisalo preko sadržaja 
testa (inteligencije naspram opažanja vizuelnih draži), greška preterivanja nije se značajno razlikovala u "visoko uključujućem" kontekstu, kao što je pretpostavljeno; kada se involviranošću manipulisalo preko učešća u aktivnosti (akter naspram posmatrača), efekti su bili snažniji: u slučaju aktera registrovana je greška preterivanja, a u nekim situacijama, u slučaju posmatrača to je zapravo bila obrnuta tendencija, greška potcenjivanja.

U eksperimentu u kome je manipulisano kvalitetom postignuća, "neuspešna" značajno je više korigovala skorove u poređenju sa "uspešnom" grupom (Tabela 37).

Za predviđanje obima greške preterivanja u svakom ogledu korišćen je set prediktora sačinjen od eksperimentalnih faktora i niza mera samoizveštaja, koje su ukazivale na nivo adaptiranosti (samopoštovanje, pozitivnost dominantnog afekta, opšta životna orijentacija (optimizam) i akademske ambicije), kao i dodatne mere pozitivnosti pamćenja (indeks pozitivnosti spontano evociranih autobiografskih događaja). Procenat objašnjene varijanse kretao se od $13 \%$ do $49 \%$. O razlozima za ovaj, prilično veliki raspon u ovom trenutku možemo spekulisati: za početak, razmotrićemo problem ekološke validnosti ogleda. Najveći procenat objašnjene varijanse izmeren je u prvom ogledu, koji je bio i ekološki najvalidniji. U ovom ogledu je i najviše dispozicionih prediktora bilo značajno (opšti životni optimizam i samopoštovanje). Postignuća o kojima su ispitanici izveštavali bila su stvarna i od značaja za sliku o sebi. U eksperimentu koji je bio najartificijelniji (u kome su ispitanicima dati lažne povratne informacije o uspehu ili neuspehu na fiktivnom testu znanja), procenat objašnjene varijanse bio je najmanji. 
Tabela 37

Pregled glavnih rezultata svih ogleda ${ }^{26}$

\begin{tabular}{|c|c|c|c|c|c|c|}
\hline \multirow{3}{*}{ Eksperiment 1} & \multicolumn{2}{|c|}{ Memorijska dostupnost } & Uključenost & \multicolumn{2}{|c|}{$\begin{array}{l}\text { Motivacija: tačnost ili } \\
\text { samopredstavljanje }\end{array}$} & \multirow[t]{2}{*}{$\begin{array}{c}\text { Uspešnost u } \\
\text { zadatku }\end{array}$} \\
\hline & \multicolumn{2}{|c|}{$\begin{array}{l}\text { Studenti prve i treće } \\
\text { godine }\end{array}$} & \multirow[t]{2}{*}{-- } & \multicolumn{2}{|c|}{$\begin{array}{c}\text { Instrukcija: što tačnije ili bez } \\
\text { specifikacije }\end{array}$} & \\
\hline & $\chi^{2}$ & $(\mathrm{~F})$ & & $\chi^{2}$ & $\mathrm{~F}$ & \\
\hline Prijemni & ns. & $* * *$ & & ns. & $n s$. & \\
\hline Srednja škola & $n s$. & $n s$. & & $* * *$ & $* * *$ & \\
\hline
\end{tabular}

Značajni prediktori (srednja škola): Instrukcija za prisećanje, indeks pozitivnosti spontano navedenih autobiografskih sećanja. Procenat objašnjene varijanse: $28 \%$

Značajni prediktori (prijemni): Memorijska dostupnost događaja, indeks pozitivnosti AB sećanja, Opšti životni optimizam,

Samopoštovanje. Procenat objašnjene varijanse: $49 \%$

\begin{tabular}{lcccccc}
\hline Eksperiment 2 & \multicolumn{2}{c}{$\begin{array}{c}\text { Neposredno retestiranje i } \\
\text { nakon 7-10 dana }\end{array}$} & $\begin{array}{c}\text { Sadržaj testa: vizuelna } \\
\text { percepcija ili opšta } \\
\text { kognitivna sposobnost }\end{array}$ & \multicolumn{2}{c}{$\begin{array}{c}\text { Javno ili privatno } \\
\text { saopštavanje rezultata }\end{array}$} \\
Ukupan skor & $\chi^{2}$ & $\mathrm{~F}$ & $\chi^{2}$ & $\mathrm{~F}$ & $\chi^{2}$ & $\mathrm{~F}$ \\
Zbir odstupanja & $-* *$ & $* * *$ & $n s$. & $n s$. & $* * *$ & $* * *$ \\
\hline
\end{tabular}

Značajni prediktori (ukupan skor): Memorijska dostupnost događaja, Javnost situacije, indeks pozitivnosti AB sećanja.

Procenat objašnjene varijanse: $19 \%$

\begin{tabular}{|c|c|c|c|c|c|c|c|c|}
\hline \multirow[t]{2}{*}{ Eksperiment 3} & \multicolumn{2}{|c|}{$\begin{array}{l}\text { Neposredno retestiranje } \mathrm{i} \\
\text { nakon 7-10 dana }\end{array}$} & \multicolumn{2}{|c|}{--} & \multicolumn{2}{|c|}{$\begin{array}{c}\text { Javno ili privatno } \\
\text { saopštavanje rezultata }\end{array}$} & \multicolumn{2}{|c|}{$\begin{array}{c}\text { Fidbek o } \\
\text { uspehu/neuspehu }\end{array}$} \\
\hline & $\chi^{2}$ & $\mathrm{~F}$ & & & $\chi^{2}$ & $\mathrm{~F}$ & $\chi^{2}$ & $\mathrm{~F}$ \\
\hline Ukupan skor & $* * *$ & $* * *$ & & & $n s$. & $* * *$ & $* * *$ & $n s$. \\
\hline Zbir odstupanja & -- & $* * *$ & & & -- & $n s$. & -- & $* * *$ \\
\hline \multicolumn{9}{|c|}{ Značajni prediktori (ukupan skor): Memorijska dostupnost događaja, Procenat objašnjene varijanse: $13 \%$. } \\
\hline \multirow[t]{2}{*}{ Eksperiment 4.1} & \multicolumn{2}{|c|}{--} & \multicolumn{2}{|c|}{ Akter ili posmatrač } & \multicolumn{2}{|c|}{--} & \multicolumn{2}{|c|}{--} \\
\hline & & & $\chi^{2}$ & $\mathrm{~F}$ & & & & \\
\hline Prvi deo & & & $n s$. & $* * *$ & & & & \\
\hline Drugi deo & & & $* * *$ & $* * *$ & & & & \\
\hline
\end{tabular}

Značajni prediktori (drugi deo): Akter/posmatrač. Procenat objašnjene varijanse: $46 \%$.

\begin{tabular}{lccc}
\hline Eksperiment 4.2 & Akter ili posmatrač & -- \\
& $\chi^{2}$ & $\mathrm{~F}$ \\
& $* * *$ & $* * *$ & \\
\hline Značajni prediktori: Akter/posmatrač. Procenat objašnjene varijanse: $33 \%$. &
\end{tabular}

Značajni prediktori: Akter/posmatrač. Procenat objašnjene varijanse: $33 \%$.

\begin{tabular}{lc}
\hline Eksperiment 5 & Svoja ili tudja grupa \\
Broj atributa & $* * *$ \\
Pozitivnost & $* * *$ \\
Tačnost & $n s$. \\
Skor test 1 & $n s$. \\
Skor test 2 & $* * *$ \\
Skor test 3 & $*$ \\
Skor test 4 & $* * *$ \\
Ukupan skor & $* * *$ \\
\hline Napomena: $* * *$ značajnost na nivou $\mathrm{p}<.01 ; * *$ značajnost na nivou $\mathrm{p},<.05 ; *$ značajnost na nivou $\mathrm{p}<.1$
\end{tabular}

\footnotetext{
${ }^{26} \chi^{2}$ test odnosi se na značajnost razlika u broju precenjivača naspram tačnih izveštača, a F (analiza varijanse) na značajnost razlike u obimu greške precenjivanja.
} 
Koji je proces zapravo $u$ pitanju? Pre svega, da li je u pitanju autobiografsko pamćenje (izuzev poslednjeg eksperimenta, u kome nije ni predviđeno da bude)? Ukoliko ga definišemo kao striktno epizodičko, onda samo eksperimenti 2, 3 i 4 zapravo ispituju sećanje ispitanika na konkretne događaje (rešavali su test i dobijali informaciju o postignuću). U prvom ogledu, međutim, ispitanici teško da se prisećaju događaja u kome im je prvi put saopšten uspeh u srednjoj školi, pre će biti da se prisećaju znanja koja nemaju tako jasne prostorno-vremenske koordinate. Čitalac, dakle, treba da ima na umu da kada se u tekstu govori o autobiografskom pamćenju, govori se zapravo o obe vrste informacija o sebi: i o jedinstvenim događajima u prostoru i vremenu, ali i o apstrahovanim sećanjima na sopstvena ponašanja, mišljenja i osećanja. Glavno pitanje na koje ćemo pokušati da odgovorimo u ovom odeljku je da li se dobijeni obrazac rezultata može u potpunosti objasniti kognitivnim procesom rekonstrukcije na osnovu utiska o događaju (eng. gist). Drugim rečima, da li je moguće da je registrovana pristrasnost u stvari posledica shematizacije događaja (u kategorije "dobar rezultat", "bolji od većine", "uspešno" i slično) i naknadne rekonstrukcije specifičnih činjenica na osnovu aktivirane sheme. Čini se, pre svega, da je doslednost u pozitivnosti distorzije teško objašnjiva na ovaj način; kako su, međutim, povratne informacije i u prvom i u drugom ogledu zapravo označavale uspeh, o čemu je već bilo reči, samo je treći ogled "kritičan" za proveru ove hipoteze. Da je u pitanju rekonstrukcija, neuspešna grupa bi umanjivala, a ne uvećavala svoje rezultate. Uz to distorzije bi se "razilazile" sa vremenom, pa bi razlika između uspešne i neuspešne grupe u kasnijem izveštaju trebalo da bude veća, a ne manja, kao što je dobijeno u našem ogledu. U ogledu koji metodološki najviše odgovara našem (Gramzow \& Willard, 2009) obrazac rezultata ukazivao je upravo na rekonstruktivne procese: uspešna grupa je povećavala, a neuspešna nije povećavala svoje rezultate; razlika među njima rasla je u naknadnom retestu. Jedina značajna razlika (pored kulturoloških, a za zaključivanje o kulturološkim razlikama uzorak nije ni adekvatan ni reprezentativan) na koju možemo ukazati je da su u njihovom ogledu događaji interpretirani od strane istraživača, pa je rezultat odmah svrstavan u kategoriju uspeh ili neuspeh, dok u našem ogledu nije bilo kvalitativne interpretacije, već je ispitanicima samo saopšten njihov percentilni rang. U seriji ogleda Daninga i saradnika (Dunning et al., 2004) ubedljivo je pokazano kako deficit u informacijama vodi precenjivanju sopstvenih postignuća. U većini njihovih ogleda, međutim, ispitanici nisu dobijali direktan fidbek o uspehu (nekada su dobijali povratne informacije o tačnosti pojedinačnih odgovora, a nekada ni to), već su pretpostavljali koji bi mogao biti njihov skor (nekada u procentima rešenih zadataka, a nekada u percentilnom rangu, dakle poređenju sa 
drugima). U nekim od naših ogleda, studenti su dobijali fidbek o uspehu. Da bi fidbek bio manje jednoznačan, i davao im izvesnu amplitudu greške, dobijali su informacije o postignuću na tri subtesta i ukupnom testu. Pored toga, polovina ispitanika retestirana je nakon nedelju i više dana, što im je takođe dozvoljavalo da transformišu zapamćen materijal. U ogledima akter-posmatrač, ispitanici su dobijali parcijalni fidbek o uspehu na pojedinim zadacima. U Daningovim, kao i u našim ogledima utvrđeno je da se - kada ispitanici nemaju pristup tačnim rezultatima - njihove procene postignuća "pomeraju" naviše.

Da bismo dobili definitivan odgovor na pitanje da li je u pitanju rekonstrukcija na osnovu opšteg utiska ili motivisana distorzija, čini se da je potrebno detaljnije istraživati proces transformisanja informacije o sopstvenom postignuću, pre svega interpretacije skora.

Funkcije memorijskih pristrasnosti. Zbog čega dolazi do pozitivnih pristrasnosti u memoriji? U uvodnoj diskusiji kao dve moguće funkcije naveli smo regulaciju afekta i očuvanje pozitivne slike o sebi. Pamćenje nam, dakle, "vraća" sliku prošlih događaja koja je retuširana tako da nam ugodi. Da li se mogu naći primeri retuširanja memorije koji nemaju direktne, ili čak ni pozitivne posledice za sliku o sebi? Neka istraživanja afektivnog tona kao organizatora autobiografske memorije (Charles, Mether \& Carstensen, 2003; Kennedy, Mather \& Carstensen, 2004) utvrđuju razlike u broju i kvalitetu upamćenosti prijatnih naspram neprijatnih događaja, a da pritom prijatni događaji nisu nužno vezani za sliku o sebi niti za sopstvene kompetencije. Neke empirijski utvrđene pravilnosti u kolektivnom pamćenju, takođe bi se mogle svrstati u ovu grupu: sećanja ljudi na prethodne istorijske periode često su pozitivno pristrasna ("dobra stara vremena"). Tako, na primer, veliki broj socijalnopsiholoških i socioloških istraživanja u istočnoevropskim i balkanskim zemljama otkriva da su ljudi nostalgični za periodom socijalizma odnosno komunizma (Boym 2001; Bach 2002; Jakobi, 2010). Analitičari su skloni da ovu pojavu objasne realnim razlikama u svakodnevnom životu: bržim tempom življenja, niskim standardom, surovijim zakonima tržišta, osećajem napuštenosti i nezaštićenosti. Kada se uporede objektivni parametri životnog standarda, pa čak i izveštaji o nivou zadovoljstva sopstvenom materijalnom situacijom i životnom perspektivom, ne dobijaju se podaci koji u potpunosti potvrđuju tezu o stvarnim razlikama. Čini se da nostalgiji u mnogome doprinosi upravo mehanizam selektivnog pamćenja i retuširanja prošlih događaja koji deluje nezavisno od drugih okolnosti. Istorijske su činjenice da se, nakon ozbiljnih i dugotrajnih ratnih sukoba, ljudi mire, opraštaju jedni drugima i nastavljaju da sarađuju. Zalečenje zapravo predstavlja ustupanje mesta pozitivnim sećanjima i zaboravljanje ili distorziju, ublažavanje drugih. 
S druge strane, postoje autori koji tvrde da ne postoji generalna pristrasnost prema prijatnim dešavanjima, već prema onim koji su od značaja za sliku o sebi. Prema njihovom mišljenju, bolje i detaljnije pamćenje autobiografskih događaja važi isključivo za samoreferentne autobiografske događaje, ali ne i za sve prijatne događaje, odnosno one koji, na primer, uključuju druge ljude (D'Argembebau \& Van der Linden, 2008). Može se pretpostaviti, međutim, da evociranje upravo ovih događaja izaziva najveću prijatnost, pa da i rukovodeći se pretpostavkom o regulaciji afekta možemo očekivati da oni imaju primat u zapamćivanju. Neki eksperimentalni nalazi na prvi pogled nisu objašnjivi hipotezom o regulaciji afekta: već smo pominjali situacije u kojima se ljudi sećaju pređašnjih neuspeha, koje smo interpretirali kao posledicu potrebe da se potvrdi predstava o sebi kao osobi koja napreduje, usavršava se, pozitivno menja (Ross \& Willson, 2009). Evociranje neprijatnih prošlih događaja ne donosi direktno osećaj prijatnosti. Može se, međutim, pretpostaviti da onaj koji se priseća nalazi sekundarno zadovoljstvo u potvrđivanju aktuelne pozitivne slike o sebi.

Čini se da je teško konceptualno i operacionalno razmrsiti efekte ova dva motiva; za diskusiju o motivisanom pamćenju, međutim, važnije je konfrontirati njihove zajedničke efekte sa motivom za tačnošću, za objektivnim registrovanjem autobiografskih događaja.

Ograničenja u obimu precenjivanja. Iako je procenat precenjivača u svim ogledima između $60 \%$ i $70 \%$, obim distorzije je relativno mali i ne prelazi $10 \%$ od inicijalnih rezultata. To govori u prilog pretpostavci da intervencije na zapamćenom materijalu ne smeju da dovedu do kvalitativne izmene događaja, da treba da budu uverljive onome kome se saopštava, a i samom akteru. O ovom, nazovimo ga, ograničenju realnosti (eng. reality constraint) bilo je reči u vezi sa motivisanim rezonovanjem. Kunda je u svom uticajnom preglednom članku "Motivisano rezonovanje" pretpostavila da ukoliko osoba želi da dođe do određenog zaključka, odnosno da ima određeno uverenje koje odgovara slici o sebi, oseća se obaveznom da konstruiše opravdanje za taj zaključak/uverenje koje bi bilo plauzibilno za nepristrasnog posmatrača (Kunda, 1990). U procesu potkrepljivanja željenog zaključka/slike o sebi, osoba evocira pristrasan uzorak relevantnih verovanja i pravila, pristrasan uzorak autobiografskih događaja, odnosno koriguje verovanja, pravila i događaje u meri u kojoj joj to dozvoljava aktuelni sistem uverenja koji poseduje. Najveća prosečna promena registrovana u našem ogledu bila je 4.5 na skali od 100 percentila. Slični rezultati dobijeni su u ogledu u kome su ispitanici učestvovali $\mathrm{u}$ treningu $\mathrm{u}$ kome su promovisane vrednosti socijalnih veština, a umanjivan značaj prethodnog znanja za uspeh u biznisu; ispitanici su nakon toga uvećavali procenu sopstvenih socijalnih veština, a umanjivali procenu prethodnog znanja (Dunning, Story \& Tan, 1989). U grupi kojoj su na treningu date suprotne informacije, i promene su 
bile u suprotnom smeru. Magnituda promene je ipak bila relativno mala i iznenađujuće podudarna sa onom u našem ogledu (4.3 na skali od 100 percentila), što ukazuje na to da su promene bile ograničene prethodnim samoprocenama.

Da bi se kognitivne pristrasnosti nazvale adaptivnim, moraju biti u optimalnim marginama. Postoje empirijski nalazi o tome da je samoprocena koja se podudara sa procenama drugih (izostanak samoprecenjivanja) karakteristična za ljude sa višom depresivnošću, pasivne, nesklone riziku i preuzimanju odgovornosti (Baumeister, 1989; McAllister et al., 2002). S druge strane, preterano distortirana izmenjena slika o sebi može dovesti do ignorisanja stvarnog rizika (Kunda, 1990), neuspeha u socijalnim interakcijama (Colvin \& Block, 1994) ili odustajanja od zadataka (deca koja imaju sindrom hiperaktiviteta često imaju nerealistično pozitivnu sliku o sopstvenim sposobnostima, a da je ne bi ugrozili oni se zapravo povlače iz situacija koje im predstavljaju izazov, Hoza et al., 2004).

Rašireno je uverenje da pogrešna procena vodi manjoj efikasnosti. Naravno, ogromne greške u proceni mogu napraviti probleme. Međutim, optimistične samoprocene sposobnosti koje ne odudaraju previše od onoga što je moguće, mogu zapravo biti prednost, dok tačne procene mogu biti samohendikepirajuće. Kada ljudi greše u samoproceni, oni najčešće precenjuju sopstvene sposobnosti. Ovo je prednost a ne greška koju treba korigovati. Kada bi uverenja o sopstvenoj efikasnosti uvek odražavala ono što ljudi mogu da urade rutinski, retko bi grešili ali bi isto tako retko ulagali dodatni napor da prevaziđu svoj standardni nivo postignuća (Bandura, 1989, str. 1177).

Kao jedan opštiji zaključak, može se reći da su motivisane distorzije u pamćenju ograničene potrebom za tačnošću, odnosno da primarna funkcija pamćenja (registrovanje prošlih događaja) ostaje dominantna, iako su zapamćeni događaji donekle "hedonistički editovani". Obmanjivanje ili samoobmanjivanje. Rezultati do kojih smo došli ne daju jasnu potvrdu nijednoj od dve konkurentske hipoteze: ukoliko zauzmemo stanovište da su registrovane greške zapravo greške u izveštavanju a ne pamćenju i da su posledica želje za samopredstavljanjem, treba objasniti činjenicu da se javljaju u anonimnoj situaciji, pod šifrovanim imenom. Svakako se može pretpostaviti da se i u toj situaciji, iako u manjoj meri, javlja potreba za samopredstavljanjem, i reći da je nepotrebno pozivati se na složenije kognitivne procese. S druge strane, može se pretpostaviti, a neke od teorija koje smo predstavili u uvodu to i čine (npr. teorija nejasnog traga, Brainerd \& Rayna, 1995; 2001) da ljudi paralelno pohranjuju dve vrste informacija u memoriju: doslovna i suštinska sećanja, te da su distorzije o kojima je reč posledica pristupu suštinskim sećanjima, gde je u ovom slučaju pohranjen kontekst događaja uz neki opseg postignuća. Ovome je doprineo i eksperimentalni dizajn u kome je svakom ispitaniku saopštavan niz skorova (najčešće četiri), 
pa se može pretpostaviti da je i ta varijablnost "dozvoljavala" ispitanicima da se ne oslone na doslovne tragove, već na opseg postignuća.

Sklonost ka temporalnim pristrasnostima. Iako u našem nacrtu nisu predviđena ponovljena merenja greške preterivanja, ipak su za svakog ispitanika izmerene tri mere odnosa prema sopstvenoj prošlosti i budućnosti: (a) sklonost ka preuveličavanju prošlih postignuća, (b) proporcija pozitivno valentnih autobiografskih sećanja $\mathrm{u}$ bloku spontano navedenih autobiografskih sećanja (AB) i (c) optimizam, odnosno stav prema budućnosti (LOT). U većini ogleda utvrđena je korelacija između (a) i (b), a naše je mišljenje da ovom nalazu treba posvetiti dodatnu pažnju. Za to postoji nekoliko važnih razloga: ova dva parametra nemaju zajedničku metodsku varijansu, ispitanici ne pokušavaju da budu dosledni u izveštavanju o autobiografskim sećanjima (to donekle garantuje i dvofazna struktura samog zadatka u kome se o afektivnoj valenci pitaju tek nakon što navedu događaje), ne postoji pritisak ka socijalnoj poželjnosti kada je u pitanju $\mathrm{AB}$ mera, niti implicitne pretpostavke o tome sa čime bi ona trebalo da bude povezana. Zahvaljujući tome, može se zaključiti da je utvrđena korelacija više konceptualna, nego metodska (Podsakoff et al., 2003). Iako se LOT povremeno priključuje ovoj grupi, u mnogim ogledima ova povezanost nije značajna, tako da u ovom trenutku ne možemo reći da čine homogenu skupinu koja se odnosi na hedonističko prekrajanje prošlih i optimističko viđenje budućih događaja.

Adaptivnost greške preterivanja. Naši nalazi svakako ne daju snažno potkrepljenje pretpostavci o adaptivnosti greške preterivanja: korelacije mere preterivanja sa indikatorima adaptiranosti su nedosledne i ne previše visoke. $\mathrm{S}$ druge strane, greška preterivanja registrovana je u jednoj specifičnoj situaciji, na testu konkretnog sadržaja, kod polovine ispitanika neposredno nakon testa. Ovaj niz ograničenja nas zapravo onemogućava da govorimo o sklonosti ka grešci preterivanja i umanjuje šanse da se utvrdi značajna povezanost sa dispozicionim varijablama. Pored toga, korelacije su računate odvojeno za svaki eksperiment, a u okviru poduzoraka postojale su grupe izložene različitim eksperimentalnim tretmanima, što je na kraju značilo relativno malo ispitanika po grupi. U ekološki najvalidnijem eksperimentu utvrđen je i najveći broj značajnih povezanosti. Matrica korelacija među samim indikatorima ukazala je na njihovu međusobnu povezanost $\mathrm{i}, \mathrm{u}$ najmanju ruku, na opštu sklonost ka pozitivnoj samoevaluaciji. Svi ovi rezultati ohrabruju da se adaptivnost greške preterivanja dalje istražuje, u eksperimentalnim nacrtima koji bi omogućili višestruko registrovanje pristrasnosti (da se može govoriti o sklonosti) i sa više indikatora fizičkog, socijalnog i psihičkog zdravlja. 


\section{Praktične implikacije rezultata istraživanja}

Pokušaćemo da ilustrujemo praktične implikacije rezultata ove studije u oblastima delovanja psihologa u kojima se oslanjamo na retrospektivne izveštaje aktera.

Naše istraživanje ukazuje na to da protok vremena, pored toga što umanjuje tačnost izveštaja zapravo otvara prostor za rekonstrukciju događaja u skladu sa motivima aktera. Događaji se mogu rekonstruisati tako da se očuva pozitivna slika o sebi, ili da odgovaraju slici o sebi koju trenutno imamo (Ross \& Wilson, 2003). Iako ova dva motiva najčešće deluju u istom smeru, može se zamisliti i situacija u kojoj je upravo suprotno. Ukoliko se osoba, na primer, priseća zlostavljanja u ranom detinjstvu, a razvila je sindrom žrtve i ima spoljni lokus kontrole, verovatno je da će se zlostavljanja prisećati kao intenzivnijeg i brutalnijeg nego što je ono zaista bilo. S druge strane, ako osoba sebe vidi kao kompetentnu i prilagođenu, biće sklona umanjivanju značaja prethodnih trauma, i smatraće socijalno nepoželjnim da evocira uspomene o dramatičnom zlostavljanju: u tom slučaju, verovatno je da će se događaja prisećati kao manje intenzivnog nego što je bio. Slično, ukoliko osoba treba da izveštava o tome koliko često se upuštala u neku socijalno nepoželjnu aktivnost (kockanje, konzumacija alkohola ili droga), naše istraživanje sugeriše da se mora se registrovati slika koju ispitanici u tom trenutku imaju o sebi (da li sebe vide kao izlečene ili naprotiv kao osobe koje su tek sada odlučile da se ozbiljno posvete borbi sa zavisnošću). Tek tada se može adekvatno interpretirati retrospektivni izveštaj ispitanika koji zapravo može biti precenjivanje ili potcenjivanje učestalosti nepoželjne aktivnosti.

Dalje, u našoj studiji memorijske distorzije su registrovane i u u privatnoj i sasvim anonimnoj situaciji, koja bi trebalo da bude oslobođena dejstva motiva za samopredstavljanjem. Drugim rečima, teško je uvek pripisati grešku u izveštavanju nameri ispitanika da obmane (eksperimentatora, lekara, psihologa). Verovatno je da je barem određen procenat retrospektivnih izveštaja nenamerno, automatski modifikovan što dodatno narušava njihovu pretpostavljenu validnost.

S druge strane, iako ovakva i slična istraživanja ukazuju na relativnu nepouzdanost mera samoizveštaja, ona nipošto ne sugerišu da ovaj način registrovanja prošlih ponašanja, osećanja i mišljenja ispitanika treba izostaviti ili zameniti drugim, objektivnijim. Pre svega, samoizveštaj je najekonomičniji način prikupljanja podataka, a često i jedini izvor podataka o prošlosti koji imamo. Uprkos velikim šansama da je zapamćen materijal donekle izmenjen, navedena, a i naše istraživanje ukazuju na to da su izmene ograničenog obima i da su 
registrovane razlike retko kvalitativne, suštinske. Pored toga, naši podaci takođe sugerišu da se tačnost dobijenih podataka može povećati ako u instrukciji za prisećanje na tome insistira. Da bi se razumeli motivi koji leže u osnovi mogućih distorzija trebalo bi takođe ispitati kako se ishodi događaja o kojima od njih tražimo da izveštavaju uklapaju u sliku koju ispitanici imaju o sebi. S obzirom na to da tačnost izveštaja opada, a pristrasnost raste s vremenom, $\mathrm{u}$ longitudinalnim nacrtima treba predvideti alternativne izvore podataka (dnevnički unosi, izveštaji drugih), koji bi služili kao kriterijumi za validaciju. 


\section{Ograničenja istraživanja i predlozi za buduća}

Realizacija ogleda i interpretacija rezultata omogućili su nam da uočimo kako bi se eksperimentalni dizajn mogao unaprediti i kako bi rezultati mogli da posluže kao osnova za buduća istraživanja u ovoj oblasti.

Pre svega, da bi se moglo govoriti o sklonosti ka grešci preterivanja, ona bi trebalo da bude registrovana u više domena (npr. testovi raznovrsnih sposobnosti) ili barem na većem broju situacija (npr. prisećanje svih ocena sa studija). Pri tom, treba voditi računa o ekološkoj validnosti eksperimenta: naši rezultati sugerišu da su mere preterivanja valjanije ukoliko je reč o značajnom postignuću, koje ima realne životne posledice.

Što se tiče pretpostavke o postojanju generalne sklonosti ka temporalnim pristrasnostima, iako se nije potvrdila u našem istraživanju (utvrđene su, naime, povezanosti između greške preterivanja i pozitivnosti $u$ autobiografskom sećanju, ali ne i povezanost sa životnim optimizmom kao odnosom prema budućim događajima), po našem mišljenju trebalo bi uključiti i druge operacionalizacije ovih konstrukata (Zimbardovu skalu Vremenske perspektive, skalu Nerealističnog optimizma i slično).

Dalje, da bi se sistematski ispitao efekat memorijske dostupnosti, koji se pokazao najrobustnijim u našoj seriji ogleda, bilo bi dobro predvideti longitudinalno istraživanje, sa višekratnim retestiranjem tokom dužeg vremenskog perioda, kako bi se registrovalo da li pristrasnosti konstantno nastavljaju da rastu sa vremenom ili postoji "plato", odnosno ograničenje obima distorzije.

Naši rezultati ukazali su na činjenicu da do greške preterivanja dolazi i u situacijama $u$ kojima je eliminisan motiv za samopredstavljanjem: u pismenom i anonimnom izveštavanju. Buduća istraživanja bi mogla da budu osmišljena tako da se finije graduira motiv za samopredstavljanjem (umesto dihotomno, kao u našim ogledima) i proveri pretpostavka o njegovom efektu na fenomen greške preterivanja. U konstruisanju eksperimentalnih situacija mogao bi se pokriti kontinuum omeđen sa dve kontrastne situacije: potpune anonimnosti (npr. izjašnjavanje preko interneta pod šifrovanim imenom) i potpune javnosti (npr. usmeno izveštavanje pred poznatom publikom).

Efekat instrukcije se u jednom od ogleda pokazao značajnim: ispitanici kojima je naloženo da se što tačnije prisete postignuća, manje su ih pozitivno modifikovali nego oni kojima to nije sugerisano. Sadržaj instrukcije bi mogao biti glavna nezavisna varijabla u nekom budućem istraživanju, i mogao bi navoditi ispitanike da se prisete što tačnije ili da što slobodnije 
rekonstruišu sećanje. Moglo bi se manipulisati i potkrepljenjem u jednom ili drugom slučaju. Ukoliko bi se kreirala eksperimentalna situacija u kojoj bi samoizveštaji više obavezivali ispitanike: na primer, od njih se tražilo da se ponašaju u skladu sa sopstvenim izveštajima, to bi moglo doprineti rasvetljavanju dileme o zavaravanju i samozavaravanju.

Iako smo u delu posvećenom metodološkim problemima u merenju tačnosti samoevaluacije zaključili da je dizajn u kome se ispitanicima saopštava konkretno postignuće, a zatim od njih traži da o tom postignuću izveštavaju "najčistiji" u smislu objektivnosti mere preterivanja, takav nas dizajn u ipak izvesnoj meri ograničava. Ukoliko bismo se ipak, uz rizik da ispitanici dodaju različita konotativna značenja različitim osobinama, odlučili da fidbek bude opštiji, mogli bismo da izučavamo da li je sklonost samoprecenjivanju izraženija ukoliko su osobine nejasnije, apstraktnije ili ukoliko su centralnije za sliku o sebi; sadržaji koji ispitanici pripisuju različitim osobinama, u zavisnosti od toga da li je vide kao poželjnu ili nepoželjnu i kao svoju ili tuđu takođe bi mogli da budu od interesa za buduće istraživače. Test slobodnog prisećanja atributa, koji smo koristili samo u Ogledu 6 pokazao se pogodnim za izučavanje mehanizama rekonstrukcije pamćenja, tako da bi se ovaj zadatak mogao koristiti kao osnovni zadatak u istraživanju koje bi za cilj imalo upravo opis procesa rekonstrukcije i njihovu tipologizaciju. Jedan od nalaza našeg istraživanja koji bi mogao imati snažne teorijske i praktične implikacije je veća tačnost aktera koja je registrovana u izveštavanju o postignuću. Kako se izveštaji posmatrača, za koje se smatra da su nepristrasni i stoga tačniji, često koriste kao kriterijum validacije izveštaja aktera, bilo bi veoma važno ispitati u kojim situacijama su tačniji jedni, a u kojim drugi, i to upravo u ovom domenu: izveštavanje o konkretnim rezultatima na konkretnoj aktivnosti. ${ }^{27}$

$\mathrm{Na}$ kraju, hipoteza o adaptivnosti greške preterivanja mogla bi se ekstenzivnije ispitivati uključivanjem većeg broja indikatora fizičkog i psihičkog zdravlja. Zanimljivo bi bilo utvrditi i eventualne povezanosti ove sklonosti sa opštom sklonošću ka socijalno poželjnom odgovaranju (Paulhus, 2002, 2003), mada se ove generalne mere ne pokazuju u dovoljnoj meri prediktivno valjanim.

\footnotetext{
${ }^{27}$ Svesni smo, naravno, da postoji čitav niz istraživanja koja se bave asimetrijama u socijalnoj percepciji između aktera i posmatrača (veliki broj smo i navodili u diskusiji), ali nismo pronašli nijedno koje bi sistematski ispitivalo razlike u tačnosti u okviru ovog eksperimentalnog dizajna.
} 


\section{Zaključna razmatranja}

Na kraju ćemo pokušati da nalaze ove studije smestimo u kontekst istraživanja pamćenja i uže, pristrasnosti u procesu pamćenja. Preciziraćemo pritom doprinos istraživanja, ali i glavne probleme na koje je ono ukazalo.

Ljudsko pamćenje u većini slučajeva predstavlja dovoljno veran zapis prošlih događaja. Moguće je kreirati eksperimentalne uslove u kojima se registruje impresivan kapacitet pamćenja: ljudi su nekada u stanju da reprodukuju na stotine prethodno viđenih reči ili prepoznaju na hiljade slika (Mantyla, 1986). S druge strane, veliki je broj dokaza da se memorijski "output" vrlo često značajno razlikuje od "input"-a. Ovo ne samo zbog toga što se neke informacije vremenom zaboravljaju, već i zbog toga što bivaju izmenjene, modifikovane. Izučavanje grešaka u pamćenju značajno je pomoglo osvetljavanju procesa kodiranja, skladištenja i pristupa informacijama pohranjenim u memoriji (Schachter, 1995). Greške u pamćenju nisu zanimljive samo zbog toga što ukazuju na netačnost memorijskih zapisa, već i zbog toga što ukazuju na to da je ta netačnost često motivisana ličnom koristi. Socijalne psihologe upravo zanima ova kategorija grešaka u pamćenju, greške motivisane potrebom za samoosnaživanjem, koje smo nazvali egotizmom pamćenja. Ovaj fenomen moguće je izučavati na molekularnom, individualnom nivou, kao pozitivnu distorziju lične prošlosti, ali i na molarnijim nivoima: kao pristrasnosti koje pojedinac ispoljava u interpretaciji postignuća grupe kojoj pripada, ili pak pristrasnosti koje čitavo društvo ili grupa (npr. etnička, religijska) ispoljavaju u interpretaciji sopstvene istorije.

Greška preterivanja, koju smo empirijski izučavali u većini ogleda, predstavlja poseban slučaj egotizma pamćenja: u pitanju je sklonost precenjivanju sopstvenih prošlih postignuća. Ovako precizna operacionalizacija greške u pamćenju opravdana je potrebom da se kreira kriterijum precenjivanja koji će biti objektivan i nezavistan od procena drugih, kao i dovoljno jasan da ne dozvoljava različite interpretacije. S druge strane, ovakav eksperimentalni dizajn otvorio je pitanje procesa modifikacije zapamćenog - kako modifikovati rezultat a da ga prethodno ne znamo, kako ga modifikovati tako da ostane dovoljno uverljiv, da ostane u optimalnim marginama greške. Najjednostavnije objašnjenje koje smo ponudili svodi ovu grešku na netačno izveštavanje, motivisano pre svega potrebom za samopredstavljanjem. U alternativnom objašnjenju pozivamo se na činjenicu da je do greške došlo i u situacijama u 
kojima je potreba za samopredstavljanjem verovatno eliminisana ili umanjena, i pretpostavljamo mehanizam skladištenja tačnih, ali i nejasnih tragova $u$ memoriji, i mogućnost nezavisnog pristupa jednim i drugim tragovima. Naše istraživanje je osmišljeno da ispita da li se i pod kojim uslovima javlja precenjivanje prošlih postignuća, što je obično prva i druga faza istraživanja fenomena; buduća istraživanja mogla bi proveriti koji proces mu leži u osnovi.

U nekim od ogleda izlagali smo ispitanike seriji situacija (pojedinačnih zadataka koje su rešavali uspešno ili neuspešno) i od njih zahtevali da apstrahuju jedinstvenu informaciju o postignuću. U ovom slučaju nije bilo potrebno postulirati postojanje dva odvojena memorijska zapisa- dovoljno je bilo pretpostaviti da pozitivne informacije imaju prioritet $\mathrm{u}$ kodiranju, skladištenju i izvlačenju iz memorije.

U ogledu u kome se ispitivala pristrasnost u pamćenju informacija o grupi, zadatak ispitanika bio je kombinovan: od njih se tražilo da reprodukuju liste atributa u opisu grupa (gde je moguće napraviti pristrasnu selekciju) i reprodukuju postignuća grupa na seriji testova (gde je potrebno osloniti se na informaciju o postignuću kao "kotvu").

Pretpostavka o dualnoj prirodi pamćenja daje moguće objašnjenje za obim u kome sećanja ispitanika odstupaju od realnosti. Ne daje, međutim, objašnjenje za sistematsko pozitivno odstupanje rezultata o kojima ispitanici izveštavaju od onih koji su im saopšteni. Ova se pravilnost može objasniti potrebom da se konkretni prošli događaji rekonstruišu tako da se bolje uklope u sliku o sebi, a kod većine ljudi globalna slika o sebi je pozitivna, i potrebom da evociranje prošlih događaja bude u što manjoj meri ugrožavajuće.

Ustanovili smo da su ljudi većinom skloni egotizmu pamćenja, odnosno da precenjuju sopstvena postignuća i postignuća grupe kojoj pripadaju, ali da to čine $u$ optimalnim marginama koje im dozvoljavaju da suština događaja, onako kako je upamćen, bude sačuvana. Činili su to u javnoj i u privatnoj situaciji, neposredno nakon i odloženo nakon postignuća, u situaciji uspeha i neuspeha, u ego uključujućem i manje ego uključujućem kontekstu, iako uvek više u situacijama koje a. provociraju motiv samoosnaživanja, i b. koje su manje jasne, u ovom slučaju, vremenski udaljenije. Pri tom je obim precenjivanja bio je iznenađujuće sličan onome registrovanom u slično dizajniranim istraživanjima. Serija ogleda koju smo izveli potvrdila da je u pitanju prilično robustan fenomen, i omogućila da preciznije opišemo situacije koje podstiču precenjivanje, ali i koje ispodstiču tačno odgovaranje. Pitanja odnosa motiva za tačnošću i samoprecenjivanjem, efekata aktivacije motiva za samoafirmacijom i samozaštitom, pitanja zavaravanja i samozavaravanja nisu pitanja na koja jedna studija može dati odgovore. To su zapravo važna pitanja psihologije pamćenja, 
socijalne psihologije i psihologije ličnosti. Ova pitanja nisu samo teorijski, već i metodološki relevantna, jer se sve ove psihološke discipline uglavnom oslanjaju na retrospektivne izveštaje pojedinaca. Verujemo da dalje istraživanje egotizma pamćenja može doprineti da se osvetle važna pitanja odnosa motivacije i kognicije, ali i biti koristan izvor informacija o tome kako povećati pouzdanost najčešće korišćenih mernih tehnika u psihološkoj nauci. 


\section{Reference}

Addis, D. R., \& Tippett, L. J. (2004). Memory for myself: Autobiographical memory and identity in Alzheimer's disease. Memory, 12, 56-74.

Alicke, M., \& Sedikides, C. (2009). Self-enhancement and self-protection: What they are and what they do. European Review of Social Psychology, 20, 1-48.

Anderson, J. R. (1976). Language, Memory, and Thought. Hillsdale, NJ: Lawrence Erlbaum.

Andresson, G. (1986). The benefits of optimism: A meta-analytic review of the Life Orientation Test. Personality and Individual Differeces, 21, 719-725.

Arendt, H. (1998). Izvori totalitarizma. Beograd: Feministička izdavačka kuća 94.

Arkes, H. R., Wortmann, R. C., Saville, P. D., \& Harkness, A. R. (1981). Hindsight bias among physicians weighing the likelihood of diagnosis. Journal of Applied Psychology, 66, 584 588.

Armor, D.A., \& Taylor, S.E. (1998). Situated optimism: Specific outcome expectancies and self-regulation. U M. P. Zanna (Ur.), Advances in experimental social psychology, 30 (str 309-379). New York: Academic Press.

Armor, D.A., \& Taylor, S.E. (2002). When predictions fail: The dilemma of unrealistic optimism. U T. Gilovich, D. Griffin, \& D. Kahneman (Ur.) Heuristics and Biases: The Psychology of Intuitive Judgment (str. 334-347). New York, NY: Cambridge University Press.

Aspinwall, L. G., \& Brunhart, S. M. (1996). Distinguishing optimism from denial: Optimistic beliefs predict attention to health threats. Personality and Social Psychology Bulletin, 22, 993-1003.

Bach J. (2002). 'The taste remains': consumption, (n)ostalgia, and the production of East Germany. Public Culture, 14, 545-56.

Baddeley, A. D. (1988). But what the hell is it for? U M. M. Gruneberg, P. E. Morris, \& R. N. Sykes (Ur.), Practical aspects of memory: Current research and issues: Vol. 1: Memory in everyday life (str. 3-18). Chichester, England: Wiley.

Baddeley, A.D. (2009) Foreword. What's it for? Why ask? Applied Cognitive Psychology, 23, 1045-1049. 
Bahrick, H.P., Hall, L.K., \& Berger, S.A. (1996). Accuracy and distortion in memory for high school grades. Psychological Science, 7, 265-271.

Bandura, A. (1989). Human agency in social cognitive theory. American Psychologist, 44, 1175-1184.

Barclay, C.R. (1986). Schematization of autobio- graphical memory. U Rubin D. C. (Ur.), Autobiographical Memory (str. 82- 99). New York: Cambridge Univ. Press.

Barclay, C.R. (1993). Remembering ourselves. U G.M. Davies, \& R. H. Logie (Ur.) Memory in Everyday Life (str. 285-309). Amsterdam, Elsevier.

Barclay, C.R., \& Wellman, H. M. (1986). Accuracies and inaccuracies in autobiographical memories. Journal of Memory and Language, 25, 93-103.

Bartlett, F. C. (1932). Remembering: A study in experimental and social psychology. Cambridge: Cambridge University Press.

Baumeister, R.F. (1986). Predgovor, u : R.F. Baumeister (Ur.), Public self and private self. New York: Springer Verlag.

Baumeister, R. F. (1989). The optimal margin of illusion. Journal of Social and Clinical Psychology, 8, 176-189.

Baumeister, R.F. (1998). The self. U D.T. Gilbert, S.T. Fiske, \& G. Lindzey (Ur.), Handbook of social psychology (str. 680-740). New York: McGraw-Hill.

Baumeister, R. F. (2003). Ego Depletion and Self-Regulation Failure: A Resource Model of Self-Control. Alcoholism: Clinical and Experimental Research, 27(2), 1-4.

Baumeister, R. F., Bratslavsky, E., Finkenauer, C., \& Vohs, K. D. (2001). Bad is stronger than good. Review of General Psychology, 5, 323-370.

Baumeister, R.F., Campbell, J.D., Krueger, J.I., \& Vohs, K.D. (2003). Does High Self-esteem Cause Better Performance, Interpersonal Success, Happiness, or Healthier Lifestyles? Psychological Science in the Public Interest, 4, 1-44.

Baumeister, R. F., Tice, D. M., \& Hutton, D. G. (1989). Self-presentation motivations and personality differences in self-esteem. Journal of Personality, 57, 547-579.

Beck, R.S. (2003). Motivacija: teorija i načela. Jastrebarsko: Naklada Slap.

Berntsen, D. (1996). Involuntary autobiographical memories. Applied Cognitive Psychology, $10,435-454$.

Berscheid, E., Graziano, W., Monson, T., \& Dermer, M. (1976). Outcome dependency: Attention, attribution, and attraction. Journal of Personality and Social Psychology, 34, 978-989. 
Bluck, S. (2009). Baddeley revisited: The functional approach to autobiographical memory. Applied Cognitive Psychology, 23, 1050-1058.

Bluck, S., Alea, N., Habermas, T., \& Rubin, D.C. (2005). A tale of three functions: The selfreported uses of autobiographical memory. Social Cognition 23, 91-117.

Bodroža, B. (2009). Samopoštovanje kao prediktor reagovanja na povratnu informaciju o sposobnostima (neobjavljena magistarska teza). Filozofski fakultet, Beograd.

Boucher, J., \& Osgood, C. E. (1969). The polyanna hypothesis. Journal of Verbal Learning and Verbal Behavior, 8, 1-8.

Boym S. (2001). The future of nostalgia. Basic Books, New York.

Brecker, S.J., \& Greenwald, A.G. (1981, Maj). Favorable self-referent judgments are made faster than nonfavorable ones. Rad prezentovan na 53 skupu Midwestern Psychological Association, u Detroitu.

Brewer WF. 1986. What is autobiographical memory? U D. C. Rubin (Ur.), Autobiographical Memory (str. 25-49). New York: Cambridge Univ. Press.

Briere, J., \& Conte, J. (1993). Self-reported amnesia for abuse in adults molested as children. Journal of Traumatic Stress, 6, 21-31.

Brown, J. D. (1986). Evaluations of self and others: Self-enhancement biases in social judgments. Social Cognition, 4, 353-376.

Brown, J. D. (1998). The self. Boston: McGraw-Hill.

Brown, R., \& Kulik, J. (1977). Flashbulb memories. Cognition, 5, 73-99.

Bruce, D. (1989). Functional explanations of memory. U L. W. Poon, D. C. Rubin, \& B. A. Wilson (Ur.), Everyday cognition in adulthood and late life (str. 44-58). Cambridge: Cambridge University Press.

Bruck, M., \& Ceci, S. J. (1999). The suggestibility of children's memory. Annual Review of Psychology, 50, 419-439.

Bruner, J.S., \& Tagiuri, R. (1954). The perception of people. U G. Lindzey (Ur.), The handbook of social psychology (Vol 2, str. 634-654). Reading, MA: Addison-Wesley.

Buehler, R., Griffin, D., \& MacDonald, H. (1997). The role of motivated reasoning in optimistic time predictions. Personality and social psychology bulletin, 23, 238-254.

Burton, S., \& Blair, E. (1991). Task conditions, response formulation processes, and response accuracy for behavioral frequency questions in surveys. Public Opinion Quarterly, 55, 50-79.

Burušić, J. (2007). Samopredstavljanje: taktike i stilovi. Jastrebarsko:Naklada Slap 
Campbell, J. D., \& Tesser, A. (1983). Motivational interpretations of the hindsight bias: An individual difference analysis. Journal of Personality, 51, 605-641.

Ceci, S. J., Loftus, E. F., Leichtman, M. D., \& Bruck, M. (1994). The possible role of source misattributions in the creation of false beliefs among preschoolers. International Journal of Clinical and Experimental Psychology, 42, 304-20.

Chang, E. C., Sanna, L. J., \& Yang, K. (2003). Optimism, pessimism, affectivity, and psychological adjustments in U.S. and Korea: A test of a mediation model. Personality and Individual Differences, 34, 1195-1208.

Charles, S. T., Mather, M., \& Carstensen, L. L. (2003). Aging and emotional memory: The forgettable nature of negative images for older adults. Journal of Experimental Psychology: General, 132, 310-324.

Christianson, S. (1992). Emotional stress and eyewitness memory: A critical review. Psychological Bulletin, 112, 284-309.

Chwalisz, K., Diener, E., \& Gallagher, D. (1988). Autonomic arousal feedback and emotional expe- rience: Evidence from the spinal cord injured. Journal of Personality and Social Psychology, 54, $820-828$.

Colvin, C. R., \& Block, J. (1994). Do positive illusions foster mental health? An examination of the Taylor and Brown formulation. Psychological Bulletin, 116, 3-20

Colvin, C.R., Block, J., \& Funder, D.C. (1995). Overly positive self-evaluations and personality: Negative implications for mental health. Journal of Personality and Social Psychology, 68, 1152-1162.

Colvin, C.R., Block, J. \& Funder, D.C. (1996). Psychometric truths in the absence of psychological meaning: A reply to Zuckerman and Knee. Journal of Personality and Social Psychology, 70, 1252-1255.

Conway, M. A., \& Holmes, A. (2004). Psychosocial stages and the accessibility of autobiographical memories across the life cycle. Journal of Personality, 72, 461-480.

Conway, M. A., \& Pleydell-Pearce, C. W. (2000). The construction of autobiographical memories in the self-memory system. Psychological Review, 107, 261-288.

Corenblum, B., \& Meissner, C. (2006). Recognition of faces of ingroup and outgroup children and adults. Journal of Experimental Child Psychology, 93, 187-206.

Crary, W. G. (1966). Reactions to incongruent self-experiences. Journal of Consulting Psychology, 30, 246-252. 
Crocker, J., Luhtanen, R. K., Cooper, M. L., \& Bouvrette, A. (2003). Contingencies of selfworth in college students: Theory and measurement. Journal of Personality and Social Psychology, 85, 894-908.

Crocker, J., Thompson, L. L., \& McGraw, K. M. (1987). Downward comparison, prejudice, and evaluations of others: Effects of self-esteem and threat. Journal of Psychological Review, 52, 907-916.

Cronbach, L. J. (1955). Processes affecting scores on "understanding of others" and "assumed similarity." Psychological Bulletin, 52, 177-193.

Cronbach, L. J., \& Furby, L. (1970). How should we measure "change"—Or should we? Psychological Bulletin, 74, 68-80

Cronbag, H. F. M., Wagenaar, W. A., \& Van Koppen, P. J. (1996). Crashing memories and the problem of "source monitoring". Applied Cognitive Psychology, 10, 95-104.

D'Argembeau, A., Comblain, C., \& Van der Linden, M. (2005). Affective valence and the selfreference effect: Influence of retrieval conditions. British Journal of Psychology, 96, 457-466.

Dawson, E., Gilovich, T., \& Regan, D.T. (2002). Motivated reasoning and performance on the Wason Selection Task. Personality and social psychology buletin, 28, 1379-1399.

Del Boca, F.K., \& Darkes, J. (2003). The validity of self-reports of alcohol consumption: State of the science and challenges for research. Addiction, 98, 1-12.

Della Femina, D., Yeager, C. A., \& Lewis, D. O. (1990). Child abuse: Adolescent records vs. adult recall. Child Abuse and Neglect, 14, 227-231.

Diener, E., \& Diener, C. (1996). Most people are happy. Psychological Science, 7, 181-185.

Dunning D., Heath C., \& Suls J.M. (2004). Flawed self-assessment: Implications for health, education, and the workplace. Psychological Science in the Public Interest, 5, 69- 106.

Dunning, D., Leuenberger, A., \& Sherman, D. (1995). A new look at motivated inference: Are self-serving theories of success a product of motivational forces? Journal of Personality and Social Psychology, 69, 58-68.

Dunning, D., \& McElwee, R. O. (1995). Idiosyncratic trait definitions: Implications for selfdescription and social judgment. Journal of Personality and Social Psychology, 68, 936946.

Dunning, D., Story, A. L., \& Tan, P. L. (1989). The self as model of excellence in social evaluation. Neobjavljeni rad, Cornell University.

Dutta, S., Kanungo, R. N., \& Freibergs, V. (1972). Retention of affective material: Effects of intensity of affect on retrieval. Journal of personality and social psychology, 23, 64-80. 
Dutton, K., \& Brown, J. (1997). Global self-esteem and specific self views as determinants of people's reactions to success and failure. Journal of Personality and Social Psychology, 73, 139-148.

Đerić, G. (2009). Označeno i neoznačeno u narativima društvenog pamćenja: jugoslovenski slučaj. U Bosto, S., \& Cipek, T. (Ur). Kultura sjećanja 1945. Povjesni lomovi i savladavanje prošlosti (str. 83-92). Zagreb, Disput.

Eagly, A.H., Chen, S., Chaiken, S., \& Shaw-Barnes, K. (1999). The impact of attitudes on memory: An affair to remember. Psychological Bulletin, 125, 64-89.

Eagly, A.H., Kulesa, P., Brannon, L.A., Shaw, K., \& Hutson-Comeaux, S.(2000). Why counterattitudinal messages are as memorable as proattitudinal messages: The importance of active defense against attack. Personality and Social Psychology Bulletin, 26, 1392-1408.

Eagly, A., Kulesa, P., Chen, S.,\& Chaiken, S. (2001). Do attitudes affect memory? Tests of the congeniality hypothesis. Current Directions in Psychological Science, 10, 5-9.

Ebbinghaus H. (1895/1964). Memory: A Contribution to Experimental Psychology. NewYork: Dover.

Ecco, U. (1996). From Internet to Gutenberg. Predavanje održano na Universitetu Kolumbija, preuzeto aprila 2011 sa http://www.umbertoeco.com/en/from-internet-to-gutenberg1996.html)

Efran, T. (1963). Some personality determinants of memory for success and failure (Neobjavljena doktorska disertacija). Ohio State University.

Elkind, D. (1967). Egocentrism in adolescence. Child Development, 38,1025-33.

Festinger, L. (1957). A theory of cognitive dissonance. Evanston, IL: Row \& Peterson.

Fischhoff, B. (1982). For those condemned to study the past:Heuristics and biases in hindsight. U D. Kahneman, P. Slovic, \& A. Tversky (Ur.), Judgment under uncertainty: Heuristics and biases (str. 332-351). New York: Cambridge University Press.

Fischhoff, B., \& Beyth, R. (1975). I knew it would happen. Remembered probabilities of once future things. Organizational Behavior and Human Performance, 13, 1-16.

Fiske, S. T. (2004). Social beings: A core motives approach to social psychology. New York: Wiley.

Fiske, S. T., \& Taylor, S. E. (2008). Social Cognition: From Brains to Culture. Boston, McGraw-Hill.

Freud, S. (1920/1952). A general introduction to psycho- analysis. New York: Washington Square Press. 
Freud, S. (1922). Introductory lectures on psychoanalysis. First edition,. George Allen \& Unwin Ltd, London.

Gana, K., Alaphilippe, D., \& Bailly, N. (2004). Positive illusions and mental and physical health in later life. Aging and Mental Health, 8, 58-64.

Gebauer, J. E., Broemer, P., Haddock, G., \& von Hecker, U. (2008). Inclusion-exclusion of positive and negative past selves: Mood congruence as information. Journal of Personality and Social Psychology, 95, 470-487.

Gibbons, F. X. (1986). Social comparison and depression: Company's effect on misery. Journal of Personality and Social Psychology, 51, 149-149.

Gilbert, D. T. (1998). Ordinary personology. U D. T. Gilbert, S. T. Fiske, \& G. Lindzey (Ur). The handbook of social psychology (Vol. 2, 4. Izdanje, str. 89-150). Boston: McGraw- Hill.

Gilbert, D. T., Pinel, E. C., Wilson, T. D., Blumberg, S. J., \& Wheatley, T. P. (2002). Durability bias in affective forecasting. U Gilovich, T., Griffin, D., \& Kahneman, D. (Ur.), Heuristics and biases: The psychology of intuitive judgment (str. 292-312). Cambridge: Cambridge University Press.

Gilovich, T. (1983). Biased evaluation and persistence in gambling. Journal of Personality and Social Psychology, 44, 1110-1126.

Gilovich, T. (1991). How we know what isn't so: The fallibility of human reason in everyday life. New York: The Free Press.

Gilovich, T., Griffin, D. W., \& Kahneman, D. (2002). Heuristics and biases: The psychology of intuitive judgment. New York: Cambridge University Press.

Gilovich, T., Kerr, M., \& Husted-Medvec, V. (1993). Effect of temporal perspective on subjective confidence. Journal of Personality and Social Psychology, 64, 552-560.

Gramzow, R.H., Gaertner, L., Sedikides, C. (2001). Memory for ingroup and outgroup information in a minimal group context: The self as an informational base. Journal of Personality and Social Psychology 80, 188-205.

Gramzow, R.H., Elliot, A.J., Asher, E., \& McGregor, H. (2003). Self- evaluation bias and academic performance: Some ways and some reasons why. Journal of Research in Personality, 37, 41-61.

Gramzow, R. H., \& Willard, G. (2006). Exaggerating current and past performance: Motivated self-enhancement versus reconstructive memory. Personality and Social Psychology Bulletin, 32, 1114-1125.

Green, J. A., \& Sedikides, C. (2004). Retrieval selectivity in the processing of self-referent information: Testing the boundaries of self-protection. Self and identity, 3, 69-80. 
Greenwald, A. G. (1980). The totalitarian ego: Fabrication and revision of personal history. American Psychologist, 35, 603-618.

Greenwald, A. G. (1981). Self and memory. U G. H. Bower (Ur.), The psychology of learning and motivation (Vol. 15, str. 201-236). New York: Academic Press.

Greenwald, A. G. (1997). Self-knowledge and self-deception: Further consideration. U M. S. Myslobodsky (Ur.), The mythomanias: An inquiry into the nature of deception and selfdeception (str. 51-71). Mahwah, NJ: Erlbaum.

Groeger, J. A., \& Grande, G. E. (1996). Self-preserving assessments of skill? British Journal of Psychology, 87, 61-79.

Guenther, C. L. \& Alicke, M. D. (2008) Self-enhancement and belief perseverance. Journal of Experimental Social Psychology, 44, 706-12.

Halbwachs, M. (1992). On collective memory. Chicago: University Press.

Hancock, J. T., Toma, C., \& Ellison, N. (2007). The truth about lying in online dating profiles. Zbornik radova sa konferencije SIGCHI On Human Factors in Computing Systems (str. 449-452). New York: ACM Press.

Hansford, B. C., \& Hattie, J. A. (1982). The relationship between self and achievement/ performance measures. Review of Educational Research, 52, 123-142.

Harring, K.E. \& Gaertner, L. (1992, April). Social categorization affects recall for ingroup and outgroup members' attitudes. Rad prikazan na 63 godišnjem sastanku Eastern Psychological Assotiation, Boston, MA.

Harter, J. K. (1997). The psychometric utility of the midpoint on a Likert scale (Neobjavljena doktorska disertacija). University of Nebraska - Lincoln. Preuzeto maja 2011 sa http://digitalcommons.unl.edu/dissertations/AAI9730273

Havelka, N. (2008). Socijalna percepcija. Zavod za udžbenike i nastavna sredstva, Beograd.

Hawkins, S. A., \& Hastie, R. (1990). Hindsight: Biased judgment of past events after the outcomes are known. Psychological Bulletin, 107, 311-327.

Heider, F. (1958). The psychology of interpersonal relations. New York: Wiley.

Herman, J., \& Schatzow, E. (1987). Recovery and verification of memories of childhood sexual trauma. Psychoanalytic Psychology, 4, 1-14.

Higgins, E. T. (1997). Beyond pleasure and pain. American Psychologist, 52, 1280-1300.

Hilgard, E.R, \& Loftus, E.F. (1979). Effective interrogation of the eyewitness. International Journal of Clinical and Experimental Psychology, 27, 342-357.

Himmelweit, H., Biberian, M. J., \& Stockdale, J. (1978). Memory for past vote: Implications of a study of bias in recall. British Journal of Political Science, 8, 365-384. 
Hodgins, D. C., \& Makarchuk, K. (2003). Trusting problem gamblers: reliability and validity of self-reported gambling behaviour. Psychology of Addictive Behaviors, 17, 244-248.

Howard, T., \& Rothbart, M. (1980). Social categorization and memory for in group and outgroup behavior. Journal of Personality and Social Psychology, 38, 301-310.

Hunter, M., Philips, C., \& Rachman, S. (1979). Memory for pain. Pain, 6, 35-46.

Hyman, I. E. Jr. (1994). Conversational remembering: Story recall with a peer versus for an experimenter. Applied Cognitive Psychology, 8, 49-66.

Hyman, I. E. Jr. (1999). Creating false autobiographical memories: Why people believe their memory errors. U E.Winograd, R. Fivush, \& W. Hirst (Ur.), Ecological approaches to cognition: Essays in honor of Ulric Neisser (str. 229-252). Hillsdale, NJ: Erlbaum.

Hyman I.E. Jr., \& Billings, F.J. (1998). Individual differences and the creation of false childhood memories. Memory, 6, 1-20.

Hyman, I. E. Jr., \& Kleinknecht, E. (1999). False childhood memories: Research, theory, and applications. U L. M. Williams \& V. L. Banyard (Ur.), Trauma and memory (str. 175188). Thousand Oaks, CA: Sage.

Hyman, I. E. Jr., \& Loftus, E. F. (1998). Errors in autobiographical memory. Clinical Psychology Review, 18, 933-947.

Hyman, I.E. Jr., \& Pentland, J. (1996). The role of mental imagery in the creation of false childhood memories. Journal of Memory and Language, 35, 101-17.

Isen, A. M., Shalker, T., \& Clark, M. (1978). Affect, accessibility of material in memory and behavior: a cognitive loop? Journal of Personality and Social Psychology, 36, 1-12.

Jahoda, M. (1958). Current concepts of positive mental health. New York: Basic Books.

Jakobi, T. (2010). Životni standard: neodređeno nezadovoljni ili dezorijentisani? U Mihajlović, S. (Ur.). Kako građani Srbije vide tranziciju iz socijalizma u kapitalizam (str. 47-59). Friedrich Ebert Stiefung, Beograd.

James, W. (1890/1950). Principles of psychology. New York: Dover (Prvo izdanje 1890).

Johnson, B. T., \& Eagly, A. H. (1989). The effects of involvement on persuasion: A metaanalysis. Psychological Bulletin, 106, 290-314.

Johnson, M. K., \& Sherman, S. J. (1990). Constructing and reconstructing the past and the future in the present. U E. T. Higgins, \& R. N. Sorrentino (Ur.), Handbook of motivation and cognition: Foundations of social behavior (Vol. 2, str. 482-526). New York: The Guilford Press.

Johnson, M. K. (2006). Memory and reality. American Psychologist, 61, 760-771. 
Jones, E. E., \& Davis, K. E. (1965). From acts to dispositions: The attribution process in person perception. U L. Berkowitz (Ur.), Advances in Experimental Social Psychology (Vol. 2, str. 219-266). New York: Academic Press.

Jones, E. E., \& Nisbett, R. E. (1972). The actor and the observer: Divergent perceptions of the causes of behavior. U E. E. Jones, D. Kanouse, H. H. Kelley, R. E. Nisbett, S. Valins, \& B. Weiner (Ur.), Attribution: Perceiving the causes of behavior (str. 79 -94). Morristown, NJ: General Learning Press.

Jovanović, K., \& Žeželj, I. (in press). The effects of framing and ego involvement on performance on the Wason selection task. Psihologija.

Judd, C.M., \& Park, B. (1988). Out-group homogeneity: Judgments of variability at the individual and group levels. Journal of Personality and Social Psychology, 54, 778-788.

Kahneman, D. Tversky, A. (1979). Prospect Theory: An Analysis of Decision under Risk. Econometrica, 97, 263-291.

Kahneman, D., \& Tversky, A. (1984). Choices, values and frames. American Psychologist, 39, $341-350$

Kamin, K. A., \& Rachlinski, J. J. (1995). Ex post L'ex ante: Determining liability in hindsight. Law and Human Behavior, 19, 89-104.

Karr, J. W. (1990). Assessing the accuracy of conflicting memories for the same event (Neobjavljena master teza). University of Waterloo, Ontario, Canada.

Kass, L.R. (Januar, 2003). Beyond therapy: Biotechnology and the pursuit of human improvement. Diskusija na sastanku President's Council on Bioethics.

Kelley, H. H. (1967). Attribution theory in social psychology. U D. Levine (Ur.), Nebraska Symposium on Motivation (Vol. 15, str. 129-238). Lincoln: University of Nebraska Press.

Kennedy, Q., Mather, M., \& Carstensen, L. L. (2004). The role of motivation in the age-related positivity effect in autobiographical memory. Psychological Science, 15, 208-214.

Kenny, D.A. (1994). Interpersonal perception A social relations analysis. New York: The Guilford Press.

Kihlstrom, J. F. (2002). Memory, autobiography, history. Proteus: A Journal of Ideas, 19 [special issue on memory], 1-6.

Kihlstrom, J. F. (2009). "So that we might have roses in December": The functions of autobiographical memory. Applied Cognitive Psychology, 23, 1179-1192.

Koren, S. (2011). "Korisna prošlost?" Ratovi devedesetih u deklaracijama Hrvatskog sabora. U Cipek, T. (Ur.). Kultura sjećanja 1991. Povjesni lomovi i savladavanje prošlosti (str. 123149). Zagreb, Disput 
Koriat, A., Goldsmith, M., \& Pansky, A. (2000). Toward a psychology of memory accuracy. Annual Review of Psychology, 51, 481-537.

Kruglanski, A. W. (1996). Motivated social cognition: Principles of the interface. U E. T. Higgins, \& A. W. Kruglanski (Ur.), Social Psychology: A Handbook of Basic Principles (str. 493- 522). New York: Guilford.

Kruttschnitt, C., \& Dornfeld, M. (1992). Will they tell? Journal of Research in Crime \& Delinquency, 29, 136-147.

Kulesa, P. (1999). The effects of expectancies on cognitive processes mediating memory for attitude relevant material (Neobjavljena doktorska disertacija). Northwestern University, Evanston, IL.

Kunda, Z. (1987). Motivation and inference: Self-serving generation and evaluation of evidence. Journal of Personality and Social Psychology, 53, 636-647.

Kunda, Z. (1990). The case for motivated reasoning. Psychological Bulletin, 108, 480-498.

Kunda, Z. (1999). Social cognition: Making sense of people. Cambridge, MA: The MIT Press.

Kunda, Z., \& Sanitioso, R. (1988). Motivated changes in the self concept. Journal of Experimental Social Psychology, 25, (272-285).

Kunda, Z., \& Sanitioso, R. (1991). Motivational versus cognitive accounts: Response to Pitz. Journal of Behavioral Decision Making, 4, 177-178.

Landau, M., Greenberg, J., \& Sullivan, D. (2009). Defending a coherent autobiography: When past events appear incoherent, mortality salience prompts compensatory bolstering of the past's significance and the future's orderliness. Personality and Social Psychology Bulletin, 35, 1012-1020.

Langer, E. J. (1975). The illusion of control. Journal of Personality and Social Psychology, 32, 311-328.

Leary, M. R. (1982). Hindsight distortion and the 1980 Presidential election. Personality and Social Psychological Bulletin, 8, 257-263.

Leary, M.R. \& Kowalski, R.M. (1990). Impression management: A literature review and two component model. Psychological Bulletin, 107, 34-47.

LeDoux, J. (2002). Synaptic self: how our brains become who we are. New York, Viking Penguin.

Leszczynska, A. (2011). Motivational and reconstructive memory distorsions on information important for the self (Neobjavljena doktorska teza). Jagiellonian University, Kraków, Poland. 
Levine, J. M., \& Murphy, G. (1943). The learning and forgetting of controversial material. Journal of Abnormal and Social Psychology, 38, 507-517.

Levine, L. J., Lench, H. C., \& Safer, M. A. (2009). Persistence, fading, and bias in memory for emotion. Applied Cognitive Psychology, 23.

Lewandowsky, S., Stritzke, W. G. K., Oberauer, K., \& Morales, M. (2005). Memory for fact, fiction, and misinformation. Psychological Science, 16, 190-195.

Liao, S.M., \& Sandberg, A. (2008), The Normativity of Memory Modification. Neuroethics, 1, 85-99.

Lindsay, D. S., \& Read, J. D. (2006). Adults' memories of long-past events. U G.-G. Nilson, \& N. Ohta (Ur.), Memory and Society: Psychological Perspectives (str. 51-72). Hove, UK: Psychology Press.

Linton, S. J., \& Melin, L. (1982). The accuracy of remembering chronic pain. Pain, 13, 281-285.

Loftus, E. F. (1993). The reality of repressed memories. American Psychologist, 48, 518-537.

Loftus, E. F. (1997a). Memories of the past that never was. Current Directions in Psychological Science, 6(3), 60-65.

Loftus, E. F. (1997b). Creating false memories. Scientific American, 277, 70-75.

Loftus, E. F. (1999). Lost in Mall-Misrepresentations and Misunderstandings. Ethics and behavior, 9(1), 51-60.

Loftus, E. F. (2004). Memories of things unseen. Current directions in psychological science, 13(4), 145-147.

Loftus, E. F., \& Bernstein, D. M. (2005). Rich False Memories: The Royal Rode to Success. U A. F. Healy (Ur.), Experimental Cognitive Psychology and its Applications (str. 101-113). Washington DC: American Psychological Association.

Loftus, E. F., \& Pickrell, J. (1995). The formation of false memories. Psychiatric Annals, 25, $720-724$.

London, K., \& Kulkofsky, S. (2010). Factors affecting the reliability of children's forensic reports. U G. Davies \& D. B. Wright (Ur.), Current issues in applied memory research (str. 119-141). Hove: Psychology Press.

Lord, C. G., Ross, L., \& Lepper, M. R. (1979). Biased assimilation and attitude polarization: The effects of prior theories on subsequently considered evidence. Journal of Personality and Social Psychology, 37, 2098-2109.

Louie, T.A. (1999). Decision makers' hindsight bias after receiving favorable and unfavorable feedback. Journal of Applied Psychology, 84,29-41. 
Louie, T. A., Curren, M. T., \& Harich, K. R. (2000). “I knew we would win”: Hindsight bias for favorable and unfavorable team decision outcomes. Journal of Applied Psychology, $85,264-272$.

Lucas, R. E., Diener, E., \& Sub, E. (1996). Discriminant validity of well-being measures. Journal of Personality and Social Psychology, 71, 616 -628.

Luhtanen, R., \& Crocker, J. (1992). A collective self-esteem scale: Self-evaluation of one's social identity. Personality and Social Psychology Bulletin, 18, 302-318.

Lyubomirsky, S., Caldwell, N. D., \& Nolen-Hoeksema, S. (1998). Effects of ruminative and distracting responses to depressed mood on retrieval of autobiographical memories. Journal of Personality and Social Psychology, 75, 166-177.

Malle, B. F. (2006). The actor- observer asymmetry in causal attribution: A (surprising) metaanalysis. Psychological Bulletin, 132, 895-919.

Manojlović Pintar, O. (2011). Rat i nemir: o viđenjima socijalističke Jugoslavije, Drugog svetskog rata u kome je nastala i ratova u kojima se raspala. U Dimitrijević, V. (Ur.). Novosti iz prošlosti (znanje, neznanje, upotrebe i zloupotreba istorije) (str. 83-106). Beograd, Beogradski centar za ljudska prava.

Mantyla, T. (1986). Optimizing cue effectiveness: Recall of 500 and 600 incidentally learned words. Journal of Experimental Psychology: Learning, Memory and Cognition, 12, 66-71.

Mark, M. M., \& Mellor, S. (1991). Effect of self-relevance of an event on the hindsight bias: The foreseeability of a layoff. Journal of Applied Psychology, 76, 569-577.

Mather, M. (2004). Aging and emotional memory. U D. Reisberg \& P. Hertel (Ur.), Memory and emotion (str. 272-307). London: Oxford University Press.

Mather, M. (2007). Emotional arousal and memory binding: An object-based framework. Perspectives on Psychological Science 2, 33-52.

Matlin, M. W., \& Stang, D. J. (1978). The polyanna principle. Selectivity in language, memory, and thought. Cambridge, MA: Schenkman.

McAdams, D. P. (2003). Identity and the life story. U R. Fivush, \& C. A. Haden (Ur.), Autobiographical memory and the construction of a narrative self (str. 187-207). Nahwah, NJ: Lawrence Erlbaum.

McAllister, H.A., Baker, J., Mannes, C., Stewart, H., \& Sutherland, A. (2002). The optimal margin of illusion hypothesis: Evidence from the self-serving bias and personality disorders. Journal of Clinical Psychology. 21, 414-426.

McGregor, H. A., \& Elliot, A. J. (2005). The shame of failure: Examining the link between fear of failure and shame. Personality and Social Psychology Bulletin, 31, 218-231. 
Mead, G. H. (1964). Selected writings. Indianapolis: Bobbs-Merrill.

Menon, G. (1994). Judgments of behavioral frequencies: Memory search and retrieval strategies. U N. Schwarz \& S. Sudman (Ur.), Autobiographical memory and the validity of retrospective reports (str. 161-172). New York: Springer Verlag.

Mihić. Lj,, Krstić, K. \& Ignjatović, I. (2009). Autobiografska memorija i Eriksonovi stadijumi psihosocijalnog razvoja. Primenjena psihologija, 2, 307-326.

Milgrom H., Bender B., Ackerson L., Bowry P., Smith B., \& Rand C. (1996). Noncompliance and treatment failure in children with asthma. Journal of Allergy and Clinical Immunology, 98, 1051-1057.

Miller, D. T., \& Ross, M. (1975). Self-serving biases in the attribution of causality: Fact or fiction? Psychological Bulletin, 82, 213-225

Miller, J. B., DeWinstanley, P., \& Carey, P. (1996). Memory for conversation. Memory, 4, 615-631.

Mineka, S., \& Nugent, K. (1995). Mood-congruent memory biases in anxiety and depression. U D. L.Schacter (Ur.), Memory distortions: How minds, brains, and societies reconstruct the past (str. 173-193). Cambridge: Harvard University Press.

Moskowitz, G.B. (2005). Social cognition: Understanding self and others. New York: The Guilford Press.

Murray, S. L., Holmes, J. G., \& Griffin, D. W. (1996). The benefits of positive illusions: Idealization and the construction of satisfaction in close relationships. Journal of Personality and Social Psychology, 70, 79-98.

Neisser, U. (1978). Memory: What are the important questions? U M. M. Gruneberg, P.E. Morris, \& R.N. Sykes ( Ur.), Practical aspects of memory (str.3-19). London, England: Academic Press.

Neisser U. (1982). Snapshots or benchmarks. U U. Neisser (Ur.), Memory Observed: Remembering in Natural Contexts (str. 43-48). San Francisco: Freeman.

Neisser, U. (1988). What is ordinary memory the memory of? U U. Neisser \& E. Winograd (Ur.), Remembering reconsidered: Ecological and traditional approaches to the study of memory. Emory symposia in cognition, 2 (str. 356-373). New York: Cambridge University Press.

Neisser, U. (1996). Remembering as doing. Behavioral and Brain Sciences, 19, 203-204. 
Neisser U, Harsch N. (1992). Phantom flash- bulbs: false recollections of hearing the news about Challenger. U U. Neisser \& E. Winograd (Ur.), Affect and Accuracy in Recall: Studies of “Flashbulb Memories", (str. 9-31). Cambridge, UK: Cambridge University Press.

Nelson, K. (1993a). The psychological and social origins of autobiographical memory. Psychological Science, 4, 7-14.

Nelson, K. (1993b). The psychological and social origins of autobiographical memory. Psychological Science, 4, 1-8.

Nelson, K. (2003). Self and social functions: Individual, autobiographical memory and collective narrative. Memory, 11,125-136.

Nelson, K., \& Fivush, R. (2004). The emergence of autobiographical memory: A social cultural developmental theory. Psychological Review, 111, 486-511.

Neter, J., \& Waksberg, J. (1964). A study of response errors in expenditures data from household interviews. Journal of American Statistical Association 59, 18-22.

Niče, F. (1873/1986). O koristi i šteti istorije za život. Grafos, Beograd.

Nisbett, R. E., \& Ross, L. D. (1980). Human Inference: Strategies and Shortcomings of Social Judgment. Englewood Cliffs, NJ: Prentice-Hall.

Norvell, K.T., Gaston-Johansson, F., \& Fridh, G. (1987). Remembrance of labor pain: how valid are retrospective pain measurements? Pain 31, 77-86.

Oishi, S., \& Diener, E.F. (2001). Goals, culture, and subjective well-being. Personality and Social Psychology Bulletin, 27, 1674-1682.

Orwell, G. (1964). Hiljadu devetsto osamdeset četvrta. Beograd: Matica Srpska.

Ostrom, T. M., \& Sedikides, C. (1992). Out-group homogeneity effects in natural and minimal groups. Psychological Bulletin, 112, 536-552.

Owens, J. S., Goldfine, M. E., Evangelista, N. M., Hoza, B., \& Kaiser, N. M. (2007). A Critical review of self-perceptions and the positive illusory bias in children with ADHD. Clinical Child and Family Psychology Review, 10, 335-351.

Owens, J. S., \& Hoza, B. (2003). The role of inattention and hyperactivity/impulsivity in the positive illusory bias. Journal of Consulting and Clinical Psychology, 71, 680-691.

Park, B. \& Rothbart, M. (1982). Perception of out-group homogeneity and levels of social categorization: Memory for the subordinate attributes of in-group and out-group members. Journal of Personality and Social Psychology, 42, 1051-1068.

Paulhus, D. L. (1988). Interpersonal and intrapsychic adaptiveness of trait self-enhancement: A mixed blessing? Journal of Personality and Social Psychology, 74, 1197-1208. 
Paulhus, D. L. (2002): Socially Desirable Responding: The Evolution of a Constuct. U H. I. Braun, D. N. Jackson, \& D. D. Wiley (Ur.), The role of constructs in psychological and educational measurement (str. 49-69). Erlbaum, Mahwah NJ.

Paulhus, D. L. (2003): Self-presentation Measurement. U Fernandez-Ballesteros, R. (Ur.) Encyclopedia of psychological assesment (str. 858-861), Sage, Thousand Oaks, CA.

Paulhus, D. L., \& John, O. P. (1988). Egoistic and moralistic biases in self-perception: The interplay of self-deceptive styles with basic traits and motives. Journal of Personality, 66, 1025-1060.

Payne, D. G., Neuschatz, J. S., Lampinen, J. M., \& Jay, L. S. (1997). Compelling memory illusions: the qualitative characteristics of false memories. Current Directions in Psychological Science, 6, 56-60.

Peetz, J., Gunn, G. R., \& Wilson, A. E. (2010). Crimes of the past: Temporal distancing and defensiveness in the face of past in-group wrongdoing. Personality and Social Psychology Bulletin 36, 598-611

Pezzo, M. V. (2003). Surprise, defense or making sense: What removes hindsight bias?. Memory, 11, 421-441.

Pillemer, D. B. (1992). Remembering personal circumstances: A functional analysis. U E. Winograd \& U. Neisser (Ur.), Affect and accuracy in recall: Studies of "flash- bulb" memories (str. 236-264). New York: Cambridge University Press.

Pillemer, D. B. (2003). Directive functions of autobiographical memory: The guide power of the specific episode. Memory, 11, 193-202.

Pinker, S. (1990). Natural language and natural selection. Behavioral and Brain Sciences 13, 713-783.

Plaks, J. E., \& Stecher, K. (2007). Unexpected improvement, decline, and stasis: A prediction confidence perspective on achievement success and failure. Journal of Personality and Social Psychology, 93, 667-684.

Podsakoff, P. M., MacKenzie, S. B., Lee, J. Y., \& Podsakoff, N. P. (2003). Common method biases in behavioral research: A critical review of the literature and recommended remedies. Journal of Applied Psychology, 88, 879-903.

Poikoainen, K., \& Karkkainen, P. (1983). Diary gives more accurate information about alcohol consumption than questionnaire. Drug and Alcohol Dependence, 11, 209-216. 
Pontari, B. A., \& Schlenker, B. R. (2000). The influence of cognitive load on self-presentation: Can cognitive busyness help as well as harm social performance? Journal of Personality and Social Psychology, 78, 1092-1108.

Pronin, E., Gilovich, T., \& Ross, L. (2004). Objectivity in the eye of the beholder: Divergent perceptions of bias in self versus others. Psychological Review, 111, 781-799.

Pyszczynski, T., \& Greenberg, J. (1987). Toward an integration of cognitive and motivational perspectives on social inference: A biased hypothesis-testing model. U L. Berkowitz (Ur.), Advances in Experimental Social Psychology (str. 297-340). New York: Academic Press.

Reyna, V. F., Mills, B., Estrada, S., \& Brainerd, C. J. (2007). False memory in children: Data, theory, and legal implications. U M. P. Toglia, J. D. Read, D. F. Ross, \& R. C. L. Lindsay (Ur.), Handbook of eyewitness psychology (str. 479-507). Mahwah, NJ: Erlbaum.

Riess, M., Rosenfeld, P., Melburg, B. \& Tedeschi, J. T. (1981). Self-serving attributions: Biased private perceptions and distorted public descriptions. Journal of Personality and Social Psychology, 41, 224-231.

Robins, L. N. (1966). Deviant children grown up. Baltimore: Williams \& Wilkins.

Robins, R. W., \& Beer, J. S. (2001). Positive illusions about the self: short-term benefits and long-term costs. Journal of Personality and Social Psychology, 80, 340-352.

Robins, R. W., \& John, O. P. (1977). The quest for self-insight: Theory and research on the accuracy of self-perceptions. U R. Hogan, J. Johnson, \& S.R. Briggs (Ur.), Handbook of personality psychology (str. 649-679). New York: Academic Press.

Robinson, J. A., \& Swanson, K. L. (1990). Autobiographical memory: The next phase. Applied Cognitive Psychology, 4, 321-335.

Roediger, H. L. (1980). Memory metaphors in cognitive psychology. Memory and Cognition, $8,231-46$.

Roediger, H. L., \& McDermott, K. B. (1995). Creating false memories: remembering words not presented in lists. Journal of Experimental Psychology: Learning, Memory, Cognition, $21,803-814$.

Rogers, C. R. (1951). Client-centered therapy: Its current practice, implications and theory. Boston: Houghton Mifflin.

Rogers, T. B., Kuiper, N. A., \& Kirker, W. S. (1977). Self-reference and the encoding of personal information. Journal of Personality and Social Psychology, 35, 677-688.

Rohner, R.P. (1975). They love me, they love me not: A worldwide study of the effects of parental acceptance-rejection. New Haven, CT: HRAF Press. 
Rohner, R.P. (2004). The Parental "Acceptance-rejection syndrome": Universal correlates of perceived rejection. American Psychologist, 59, 827-840.

Rosenberg, M. (1965). Society and the adolescent self-image. Princeton, NJ: Princeton University Press.

Ross, M. (1989). The relation of implicit theories to the construction of personal histories. Psychological Review, 96, 341-357.

Ross, M., \& Buehler, R. (1994a). On authenticating and using personal recollections. U N. Schwarz \& S. Sudman (Ur.), Autobiographical memory and the validity of retrospective reports (str. 55-69). New York: Springer-Verlag.

Ross, M., \& Buehler, R. (1994b). Creative remembering. U U. Neisser \& R. Fivush (Ur.), The remembering self: Construction and accuracy in the self-narrative (str. 205-235). New York: Cambridge University Press.

Ross, M., McFarland, C. \& Fletcher, G. J. O. (1981). The effect of attitude on recall of past histories. Journal of Personality and Social Psychology, 10, 627-634.

Ross, M. \& Wilson, A. E. (2000). Constructing and appraising past selves. U D. L. Schachter \& E. Scarry (Ur.), Memory, brain and belief (str. 231-258). Cambridge, MA: Harvard University Press.

Ross, M., \& Wilson, A. E. (2002). It feels like yesterday: Self-esteem, valence of personal past experiences, and judgements of subjective distance. Journal of Personality and Social Psychology, 82, 792-803.

Ross, M., \& Wilson, A. E. (2003). Autobiographical memory and conceptions of the self: Getting better all the time. Current Directions in Psychological Science, 12, 66-69.

Rozin, P., \& Royzman, E. B. (2001). Negativity bias, negativity dominance, and contagion. Personality and Social Psychology Review, 5, 296-320.

Sagar, S. S., \& Stoeber, J. (2009). Perfectionism, fear of failure, and affective responses to success and failure: The central role of fear of experiencing shame and embarrassment. Journal of Sport \& Exercise Psychology, 31, 602-627.

Salovey, P., Sieber, W. J., Jobe, J. B., \& Willis, G. B. (1994). The recall of physical pain. U N. Schwarz \& S. Sudman (Ur.), Autobiographical memory and the validity of retrospective reports (str. 89-106). New York: Springer-Verlag.

Samp, J. A. \& Humphreys, L. R. (2007). "I Said What?" Partner Familiarity, Resistance, and the Accuracy of Conversational Recall. Communication Monographs, 74, 561-581.

Sanitioso, R., Kunda, Z. \& Fong, G.T. (1990). Motivated recruitment of autobiographical memories. Journal of Personality and Social Psychology, 53, 229-241. 
Sanna, L. J. \& Chang, E. C. (2003) The past is not what it used to be: Optimists' use of retroactive pessimism to diminish the sting of failure, Journal of Research in Personality, $37,388-404$.

Sanna, L. J., \& Chang, E. C. (Ur.). (2006). Judgments over time: The interplay of thoughts, feelings, and behaviors. New York: Oxford University Press.

Sanna, L. J., Chang, E. C., \& Carter, S. E. (2004). All our troubles seem so far away: Temporal pattern to accessible alternatives and retrospective team appraisals. Personality and Social Psychology Bulletin, 30, 1359-1371.

Sanna, L. J., \& Schwarz, N. (2003). Debiasing the hindsight bias: The role of accessibility experiences and (mis)attributions. Journal of Experimental Social Psychology, 39, 287-295.

Sanna, L. J., \& Schwarz, N. (2004). Integrating temporal biases: The interplay of focal thoughts and accessibility experiences. Psychological Science, 15, 474-481.

Sanna, L. J., \& Schwarz, N. (2006). Metacognitive experiences and human judgment: The case of hindsight bias and its debiasing. Current Directions in Psychological Science, 15, 172-176.

Sanna, L. J., Schwarz, N., \& Small, E. M. (2002). Accessibility experiences and the hindsight bias: I knew it all along versus it could never have happened. Memory \& Cognition, 30, 1288-1296.

Schachter, D. L. (1999). The seven sins of memory. Insights from psychology and cognitive neuroscience. American Psychologist, 54, 182-203.

Schacter, D. L, Chiao, J. Y., \& Mitchell, J. P. (2003). The seven sins of memory: implications for self. Annals of NY Academy of Science, 1001, 226-239.

Schachter, D. L. \& Tulving, E. (1994). What are the memory systems of 1994? U D. L. Schachter \& E. Tulving (Ur.), Memory systems 1994 (str 1-38). Cambridge, MA, MIT Press.

Scheier, M. F., \& Carver, C. S. (1985). Optimism, coping, and health: assessment and implications of generalized outcome expectancies. Health Psychology, 4, 219-247.

Scheier, M. F., Carver, C. S., \& Bridges, M. W. (1994). Distinguishing optimism from neuroticism (and trait anxiety,self-mastery, and self-esteem): a reevaluation of the Life Orientation Test. Journal of Personality and Social Psychology, 67, 1063-1078.

Scheier, M. F., Matthews, K. A., Owens, J. F., Magovern, G. L., Lefebvre, R. C., Abbott, R. A., \& Carver, C. S. (1989). Dispositional optimism and recovery from coronary artery bypass surgery: The beneficial effects on physical and psychological well-being. Journal of Personality and Social Psychology, 57, 1024-1040.

Schlenker, B. R. (2009). Self-presentation. U H. T. Reis \& S. Sprecher (Ur.), Encyclopedia of Human Relationship (str. 108-134). Thousand Oaks, CA: Sage. 
Schlenker, B. R., \& Pontari, B. A. (2000). The strategic control of information: Impression management and self-presentation in daily life. U A. Tesser, R. Felson, and J. Suls (Ur.), Perspectives on self and identity (str. 199-232). Washington, D.C.: American Psychological Association.

Schmela., M. (1993). Abiturienten errinern sich an ihre alten Zeugnisnoten - Qualitaet leistungbezogener autobiographisher Erinnerungen [Učenici se prisećaju završnih ocenaKvalitet pamćenja autobiografskih događaja u vezi sa postignućem]. Zeitschrift fur Paedagogische Psychologie, 7, 475-478.

Schmitt, D. P., \& Allik, J. (2005). Simultaneous administration of the Rosenberg self-esteem scale in 53 nations: Exploring the universal and culture-specific features of global selfesteem. Journal of Personality and Social Psychology, 89, 623-642.

Schmolck, H., Buffalo, E. A., \& Squire, L. R. (2000). Memory distortions develop over time: Recollections of the O. J. Simpson trial verdict after 15 and 32 months. Psychological Science, 11, 39-45.

Schwarz, N. (1999). Self-reports: How the questions shape the answers. American Psychologist, 54, 93-105.

Schwarz, N., \& Oyserman, D. (2001). Asking questions about behavior: Cognition, communication, and questionnaire construction. American Journal of Evaluation, 22, $127-160$.

Schwarz, N., \& Sudman, S. (1994). Autobiographical memory and the validity of retrospective reports. New York: Springer Verlag.

Schwarz, N., \& Wellens, T. (1997). Cognitive dynamics of proxy responding: The diverging perspectives of actors and observers. Journal of Official Statistics, 13, 159-179.

Sedikides, C. (1993). Assessment, enhancement, and verification determinants of the selfevaluation process. Journal of Personality and Social Psychology, 65, 317-338.

Sedikides, C., Gaertner, L., \& Toguchi, Y. (2003). Pancultural self-enhancement. Journal of Personality and Social Psychology, 84, 60-79.

Sedikides, C., \& Green, J. D. (2000). On the self-protective nature of inconsistency/ negativity management: Using the person memory paradigm to examine self-referent memory. Journal of personality and social psychology, 79, 906-922.

Sedikides, C., \& Green, J. D. (2004). What I don't recall can't hurt me: Information negativity versus information inconsistency as determinants of memorial self- defense. Social cognition, 22, 4-29. 
Sedikides, C., Green, J. D., \& Pinter, B. (2004). Self-protective memory. U D. R. Beike, J. M. Lampinen, \& D. A. Behrend (Ur.), The self and memory (str. 161-179). Philadelphia, PA: Psychology Press.

Sedikides, C., \& Gregg, A. P. (2003). Portraits of the self. U M. A. Hogg \& J. Cooper (Ur.), Sage handbook of social psychology (str. 110-138). London: Sage Publications.

Sedikides, C., \& Gregg, A. P. (2008). Self-enhancement: Food for thought. Perspectives on Psychological Science, 3, 102-116.

Sherman, B. R. \& Kunda, Z. (1989, Jun). Motivated evaluation of scientific evidence. Rad prezentovan na konferenciji Američkog psihološkog društva, u Arlingtonu.

Sherman, J. W., Gawronski, B., Gonsalkorale, K., Hugenberg, K., Allen, T. J., \& Groom, C. J. (2008). The self-regulation of automatic associations and behavioral impulses. Psychological Review, 115, 314-335.

Singer, J. A., \& Salovey, P. (1993). The remembered self: Emotion and memory in personality. Toronto: Maxwell Macmillan International.

Skog, O. J. (1992). The validity of self-reported drug use. British Journal of Addiction, 87, 539-548.

Skowronski, J. J., Walker, W. R., \& Betz, A. L. (2004). Who was I when that happened? The timekeeping self in autobiographical memory. U D. R. Beike, J. M. Lampinen, \& D. A. Behrend (Ur.), The self and memory (str. 183-206). New York, NY: Psychology Press.

Snyder, M. L. \& Uranowitz, S. (1978). Reconstructing the past: Some cognitive consequences of person perception. Journal of Personality and Social Psychology, 36, 941-950.

Spencer, S., Fein, S., Zanna, M. \& Olson, J. (Ur.) (2003). Motivated social perception. The Ontario sympozium Vol9. Lawrence Erlbaum Associates, London.

Sporer, S. L. (1993). Eyewitness identification accuracy, confidence, and decision times in simultaneous and sequential lineups. Journal of Applied Psychology, 78, 22-33.

Steblay, N. M. (1997). Social influence in eyewitness recall: a meta-analytic review of lineup instruction effects. Law and Human Behavior, 21, 283-297.

Stojanović, D. (2011). U ogledalu drugih. U V. Dimitrijević (Ur.), Novosti iz prošlosti (znanje, neznanje, upotrebe i zloupotreba istorije) (str. 13-31). Beograd, Beogradski centar za ljudska prava.

Strube, M. J., Yost, J. H., \& Bailey, J. R. (1992). William James and contemporary research on the self: The influence of pragmatism, reality, and truth. U M. E. Donnelley (Ur.), Reinterpreting the legacy of William James (str. 189-207). Washington, D.C.: American Psychological Association. 
Suedfeld, P., \& Eich, E. (1995). Autobiographical memory and affect under conditions of reduced environmental stimulation. Journal of Environ- mental Psychology, 15, 321-326.

Tajfel, H., \& Turner, J. C. (1986). The social identity theory of inter-group behavior. U S.

Worchel \& L.W.Austin (Ur.), Psychology of intergroup relations. Chicago: Nelson-Hall.

Taylor, S. E. (1991). Asymmetrical effects of positive and negative events: The mobilizationminimization hypothesis. Psychological Bulletin, 110, 67- 85.

Taylor, S.E., \& Brown, J. D. (1988). Illusion and well-being: A social psychological perspective on mental health. Psychological Bulletin, 103, 193-210.

Taylor, S. E., \& Brown, J. D. (1994). Positive illusions and well-being revisited: Separating fact from fiction. Psychological Bulletin, 116, 21-27.

Taylor, S.E., Kemeny, M.E., Reed, G.M., Bower, J.E., \& Greenwald, T.L. (2000). Psychological resources, positive illusions, and health. American Psychologist, 55, 99-109.

Taylor, S. E., Lerner, J. S., Sherman, D. K., Sage, R. M., \& McDowell, N. K. (2003a). Portrait of the self-enhancer: well-adjusted and well-liked or maladjusted and friendless? Journal of Personality and Social Psychology, 84, 165-176.

Taylor, S. E., Lerner, J. S., Sherman, D. K., Sage, R. M., \& McDowell, N. K. (2003b). Are self-enhancing cognitions associated with healthy or unhealthy biological profiles? Journal of Personality and Social Psychology, 85, 605-615.

Tetlock, P. E. \& Levi, A. (1982). Attribution bias: On the inconclusiveness of the cognitionmotivation debate. Journal of Experimental Social Psychology, 18, 68-88.

Thompson, C. P., Skowronski, J. J., Larsen, S., \& Betz, A. (1996). Autobiographical memory: Re-membering what and remembering when. New York: Erlbaum.

Thorne, A. (2000). Personal memory telling and personality development. Personality and Social Psychology Review, 4, 45-56.

Trope, Y. (1986). Self-enhancement and self-assessment in achievement behavior. U R. M. Sorrentino, \& E. T. Higgins (Ur.), Handbook of motivation and cognition: Foundations of social behavior (Vol. 1, str. 350-378). New York: Guilford Press.

Trope, Y., \& Liberman, N. (2003). Temporal construal. Psychological Review, 110, 403-421.

Tulving, E. (1983). Elements of episodic memory. Oxford, U.K.: Oxford University Press.

Tulving, E. (1985). Memory and consciousness. Canadian Psychologist, 26, 1-12.

Tversky, A., \& Kahneman, D. (1981). The framing of decisions and the psychology of choice. Science, 211, 453-458.

Tykocinski, O. E. (2001). I never had a chance: Using hindsight tactics to mitigate disappointments. Personality and Social Psychology Bulletin, 27, 376-382. 
Tykocinski, O. E., Pick, D., \& Kedmi, D. (2002). Retroactive pessimism: A different kind of hindsight bias. European Journal of Social Psychology, 32, 577-588.

Updegraff, J. A., \& Taylor, S. E. (2000). From vulnerability to growth: The positive and negative effects of stressful life events. U J. Harvey \& E. Miller (Ur.), Loss and trauma: General and close relationship perspectives (str. 3-28). Philadelphia, PA.

Vallerand, R. J., Pelletier, L. G., Blais, M. R., Briere, N. M., Senecal, C., \& Valleres, E. F. (1992). The Academic Motivation Scale: A measure of intrinsic, extrinsic and amotivation in education. Educational and Psychological Measurement, 52, 1003-1017.

Van Yperen, N. W. (1992). Self-enhancement among major league soccer players: The role of importance and ambiguity on social comparison behavior. Journal of Applied Social Psychology, 22, 1186-1198.

Wagenaar, W. A., \& Groeneweg, J. (1990). The memory of concentration camp survivors. Applied Cognitive Psychology, 4, 77-87.

Waldfogel, S. (1948). The frequency and affective character of childhood memories. Psychological Monographs, 62, 291-295.

Walker, W. R., \& Skowronski, J. J. (2009). The Fading Affect Bias....But What the Hell is it For?. Applied Cognitive Psychology 23, 1122-1136.

Walker, W. R., Skowronski, J. J., \& Thompson, C. P. (2003). Life is pleasant-and memory helps to keep it that way!. Review of General Psychology, 7, 203-210.

Wason, P. C. (1966). Reasoning. Harmondsworth, UK: Penguin.

Weary, G. (1978). Self-serving biases in attribution process: A re-examination of the fact or fiction question. Journal of Personality and Social Psychology, 36, 56-71.

Weaver, C. A. (1993). Do you need a "flash" to form a flashbulb memory? Journal of Experimental Psychology: General, 122, 39-46.

Weingardt, K. R., Toland, H. K., \& Loftus, E. F. (1994). Reports of suggested memories: Do people truly believe them? U D. F. Ross \& J. D. Read (Ur.), Adult eyewitness testimony: Current trends and developments (str. 3-26). New Tork: Cambridge University Press.

Weinstein, N.D. (1980). Unrealistic optimism about future life events. Journal of Personality and Social Psychology, 39, 806-820.

Wells, G. L, Small, M., Penrod, S., Malpass, R. S., Fulero, S. M., \& Brimacombe, C. A. E. (1998). Eye- witness identification procedures: recommendations for lineups and photospreads. Law and Human Behavior, 22, 603-647. 
Wheeler, D., Brunson, C., \& Walker, W. R. (2009, Maj). Individual differences in time perspective predict differences in the fading affect bias. Prezentovano na 81st Annual Meeting of the Midwestern Psychological Association, Chicago, IL.

Wheeler, S. C., DeMarree, K. G., \& Petty, R. E. (2007). Understanding the role of the self in prime-to-behavior effects: The active self account. Personality and Social Psychology Review, 11, 234-261.

Wildom, C., Spatz, S. \& Robin, L. (1996). Accuracy of adult recollections of childhood victimization. Childhood physical abuse. Psychological Assessment, 8, 412-421.

Willard, G., \& Gramzow, R. H. (2008). Exaggeration in memory: Systematic distortion of selfevaluative information under reduced accessibility. Journal of Experimental Social Psychology, 44, 246-259.

Willard, G., \& Gramzow, R. H. (2009). Beyond oversights, lies, and pies in the sky: Exaggeration as goal projection. Personality and Social Psychology Bulletin, 35, 477-492.

Williams, J. M., \& Scott, J. (1988). Autobiographical memory in depression. Psychological Medicine, 18, 689-695.

Williams, L. M. (1994). Recall of childhood trauma: A prospective study of women's memories of child sexual abuse. Journal of Consulting \& Clinical Psychology, 62, 1167-1176.

Wilson, A. E., Gunn, G. R., \& Ross, M. (2009). The role of subjective time in identify regulation. Applied Cognitive Psychology, 23, 1164-1178.

Wilson, A. E., \& Ross, M. (2003). The identity function of autobiographical memory: Time is on our side. Memory, 11, 137-149.

Ybarra, O. (1999). Misanthropic person memory when the need to self-enhance is absent. Personality and Social Psychology Bulletin, 25, 261-269.

Ybarra, O., \& Stephan, W. G. (1996). Misanthropic person memory. Journal of Personality and Social Psychology, 70, 691-700.

Ybarra, O., Stephan, W.G., \& Schaberg, L.A. (2000). Misanthropic memory for the behavior of group members. Personality and Social Psychology Bulletin, 26, 1516-1525.

Zaragoza, M. S., \& Mitchell, K. J. (1996). Repeated exposure to suggestion and the creation of false memories. Psychological Science. 7, 294-300.

Zimbardo, P. G., \& Boyd, J. N. (1999). Putting time in perspective: A valid, reliable individualdifferences metric. Journal of Personality and Social Psychology, 6, 1271-1288.

Žeželj, I. (2006) Uticaj kvaliteta argumenata, značaja teme i uključenosti primaoca na promenu stava (neobjavljena magistarska teza). Beograd, Filozofski fakultet. 
Žeželj, I., Pajić, S., Omanović, N., Ninković, J., \& Grčić. J. (2009). The impact of egoinvolvement in the creation of false childhood memories. Psihologija, 42, 289-305. 


\section{Prilozi}


- PRILOG 1 -

\author{
Instrumenti
}




\section{Baterija korišćena u Eksperimentu 1}

Za početak nam je potrebno da nam date nekoliko osnovnih informacija o sebi. Podaci se prikupljaju za naučno istraživanje, imate našu garanciju da vaša imena neće nigde biti objavljena i da će podaci biti obrađivani grupno.

Vaši podaci biće šifrirani od strane jednog, a uneti od strane drugog istraživača.

Pristajete li na učešće u eksperimentu? DA NE

Ime i prezime:

Godina studija:

Odeljenje:

Pokušajte da se prisetite i sledećih podataka. Ukoliko se ne sećate tačnog broja, upišite približan. Veoma je važno da odgovorite na sva pitanja. Svrha istraživanja biće vam detaljno objašnjena naknadno.

Prosečna ocena (upišite broj sa decimalama) u prvom razredu srednje škole:

Prosečna ocena (upišite broj sa decimalama) u drugom razredu srednje škole:

Prosečna ocena (upišite broj sa decimalama) u trećem razredu srednje škole:

Prosečna ocena (upišite broj sa decimalama) u četvrtom razredu srednje škole:

Broj poena na prijemom ispitu (upišite broj sa decimalama):

Rang na prijemnom ispitu (mesto na rang-listi): 
Molimo Vas da odvojite malo vremena i popunite list koji je pred vama.

U pitanju je naučno istraživanje, i svi podaci biće korišćeni isključivo u naučne svrhe. Nemojte previše razmišljati, odgovarajte u skladu sa onim što je vaš prvi osećaj.

Razmislite o sebi i svojim uobičajenim osećanjima.

(Zaokružite podeok na skali koji odražava vaše uobičajeno raspoloženje. Na primer, ako se nešto češće osećate umorno nego odmorno, zaokružite 5. Ako se uvek osećate veoma odmorno, zaokružite 1)

$\begin{array}{rllllllll}\text { Odmorno } & 1 & 2 & 3 & 4 & 5 & 6 & 7 & \text { Umorno } \\ \text { Srećno } & 1 & 2 & 3 & 4 & 5 & 6 & 7 & \text { Nesrećno } \\ \text { Uspešno } & 1 & 2 & 3 & 4 & 5 & 6 & 7 & \text { Neuspešno } \\ \text { Moćno } & 1 & 2 & 3 & 4 & 5 & 6 & 7 & \text { Nemoćno } \\ \text { Voljeno } & 1 & 2 & 3 & 4 & 5 & 6 & 7 & \text { Nevoljeno } \\ \text { Zaštićeno } & 1 & 2 & 3 & 4 & 5 & 6 & 7 & \text { Nezaštićeno } \\ \text { Energično } & 1 & 2 & 3 & 4 & 5 & 6 & 7 & \text { Bez energije } \\ \text { Veselo } & 1 & 2 & 3 & 4 & 5 & 6 & 7 & \text { Tužno } \\ \text { Optimistično } & 1 & 2 & 3 & 4 & 5 & 6 & 7 & \text { Pesimistično } \\ \text { Vedro } & 1 & 2 & 3 & 4 & 5 & 6 & 7 & \text { Neraspoloženo }\end{array}$

Pred vama se nalazi niz tvrdnji koje opisuju kako sebe doživljavate. Pročitajte svaku tvrdnju, i zaokružite 1-ako se uopšte ne slažete, 2-ako se uglavnom ne slažete, 3-ako se uglavnom slažete i 4-ako se sasvim slažete:

\begin{tabular}{|l|c|}
\hline Uopšteno govoreći, zadovoljan/na sam sobom. & 1234 \\
\hline Želeo/la bih da imam više samopoštovanja. & 1234 \\
\hline Osećam da ima puno toga čime bih se mogao/la ponositi. & 1234 \\
\hline Ponekad se osećam potpuno beskorisno. & 1234 \\
\hline Sposoban/na sam da radim i izvršavam zadatke jednako uspešno kao i većina drugih. & 1234 \\
\hline S vremena na vreme osećam da ništa ne vredim. & 1234 \\
\hline Osećam da posedujem niz vrednih osobina. & 1234 \\
\hline Sve više sam uveren/a u to da jako malo vredim. & 1234 \\
\hline Mislim da vredim barem koliko i drugi ljudi. & 1234 \\
\hline Osećam da sam jednako sposoban/na kao i drugi ljudi & 1234 \\
\hline
\end{tabular}


Ocenite u kojoj meri se slažete sa datim tvrdnjama:

1-ako se uopšte ne slažete, 2 -ako se uglavnom ne slažete, 3 -ako se uglavnom slažete i 4 -ako se sasvim slažete:

\begin{tabular}{|l|r|}
\hline Stalo mi je do toga da imam dobre ocene na studijama. & 1234 \\
\hline Ne mogu sebe da zamislim da poništavam ispitnu ocenu. & 1234 \\
\hline Imam razumevanja za ljude koji se žale ako nisu zadovoljni ocenom. & 1234 \\
\hline Dajem sve od sebe da budem odličan student. & 1234 \\
\hline
\end{tabular}

Razmislite na trenutak o tome šta očekujete od budućnosti. Ocenite u kom stepenu se slažete sa sledećim tvrdnjama: zaokružite 1-ako se uopšte ne slažete, 2-ako se uglavnom ne slažete, 3-ako se uglavnom slažete i 4 -ako se sasvim slažete:

\begin{tabular}{|l|c|c|}
\hline U neizvesnim vremenima obično očekujem najbolje. & 134 \\
\hline Lako mi je da se opustim. & 1234 \\
\hline Ako postoji mogućnost da mi se nešto loše desi, sigurno će se i desiti. & 1234 \\
\hline Uvek sam optimističan/na kada je moja budućnost u pitanju. & 1234 \\
\hline Veoma uživam sa svojim prijateljima. & 1234 \\
\hline Važno mi je da stalno nešto radim. & 1234 \\
\hline Gotovo nikada ne očekujem da će mi stvari „ići na ruku". & 1234 \\
\hline Ne uznemirim se tako lako. & 1234 \\
\hline Retko računam na to da će mi se lepe stvari desiti. & 2 & 2 \\
\hline Na kraju krajeva, očekujem da će mi se dobre stvari desiti pre nego loše. & 1234 \\
\hline
\end{tabular}




\section{Baterija korišćena u Eksperimentima 2 i 3}

Ime i prezime (染ra) :

Ogled br : Računar br:

Molimo Vas da odvojite malo vremena i popunite list koji je pred vama.

U pitanju je naučno istraživanje, i svi podaci biće korišćeni isključivo u naučne svrhe. Nemojte previše razmišljati, odgovarajte u skladu sa onim što je vaš prvi osećaj.

Razmislite o sebi i svojim uobičajenim osećanjima.

(Zaokružite podeok na skali koji odražava vaše uobičajeno raspoloženje. Na primer, ako se nešto češće osećate umorno nego odmorno, zaokružite 5. Ako se uvek osećate veoma odmorno, zaokružite 1)

$\begin{array}{rllllllll}\text { Odmorno } & 1 & 2 & 3 & 4 & 5 & 6 & 7 & \text { Umorno } \\ \text { Srećno } & 1 & 2 & 3 & 4 & 5 & 6 & 7 & \text { Nesrećno } \\ \text { Uspešno } & 1 & 2 & 3 & 4 & 5 & 6 & 7 & \text { Neuspešno } \\ \text { Moćno } & 1 & 2 & 3 & 4 & 5 & 6 & 7 & \text { Nemoćno } \\ \text { Voljeno } & 1 & 2 & 3 & 4 & 5 & 6 & 7 & \text { Nevoljeno } \\ \text { Zaštićeno } & 1 & 2 & 3 & 4 & 5 & 6 & 7 & \text { Nezaštićeno } \\ \text { Energično } & 1 & 2 & 3 & 4 & 5 & 6 & 7 & \text { Bez energije } \\ \text { Veselo } & 1 & 2 & 3 & 4 & 5 & 6 & 7 & \text { Tužno } \\ \text { Optimistično } & 1 & 2 & 3 & 4 & 5 & 6 & 7 & \text { Pesimistično } \\ \text { Vedro } & 1 & 2 & 3 & 4 & 5 & 6 & 7 & \text { Neraspoloženo }\end{array}$

Pred vama se nalazi niz tvrdnji koje opisuju kako sebe doživljavate. Pročitajte svaku tvrdnju, i zaokružite 1-ako se uopšte ne slažete, 2-ako se uglavnom ne slažete, 3-ako se uglavnom slažete i 4-ako se sasvim slažete:

\begin{tabular}{|l|c|}
\hline Uopšteno govoreći, zadovoljan/na sam sobom. & 1234 \\
\hline Želeo/la bih da imam više samopoštovanja. & 1234 \\
\hline Osećam da ima puno toga čime bih se mogao/la ponositi. & 1234 \\
\hline Ponekad se osećam potpuno beskorisno. & 1234 \\
\hline Sposoban/na sam da radim i izvršavam zadatke jednako uspešno kao i većina drugih. & 1234 \\
\hline S vremena na vreme osećam da ništa ne vredim. & 1234 \\
\hline Osećam da posedujem niz vrednih osobina. & 1234 \\
\hline Sve više sam uveren/a u to da jako malo vredim. & 1234 \\
\hline Mislim da vredim barem koliko i drugi ljudi. & 1234 \\
\hline Osećam da sam jednako sposoban/na kao i drugi ljudi & 1234 \\
\hline
\end{tabular}


Ocenite u kojoj meri se slažete sa datim tvrdnjama:

1-ako se uopšte ne slažete, 2 -ako se uglavnom ne slažete, 3 -ako se uglavnom slažete i 4 -ako se sasvim slažete:

\begin{tabular}{|l|r|}
\hline Stalo mi je do toga da imam dobre ocene na studijama. & 1234 \\
\hline Ne mogu sebe da zamislim da poništavam ispitnu ocenu. & 1234 \\
\hline Imam razumevanja za ljude koji se žale ako nisu zadovoljni ocenom. & 1234 \\
\hline Dajem sve od sebe da budem odličan student. & 1234 \\
\hline
\end{tabular}

Razmislite na trenutak o tome šta očekujete od budućnosti. Ocenite u kom stepenu se slažete sa sledećim tvrdnjama: zaokružite 1-ako se uopšte ne slažete, 2-ako se uglavnom ne slažete, 3-ako se uglavnom slažete i 4 -ako se sasvim slažete:

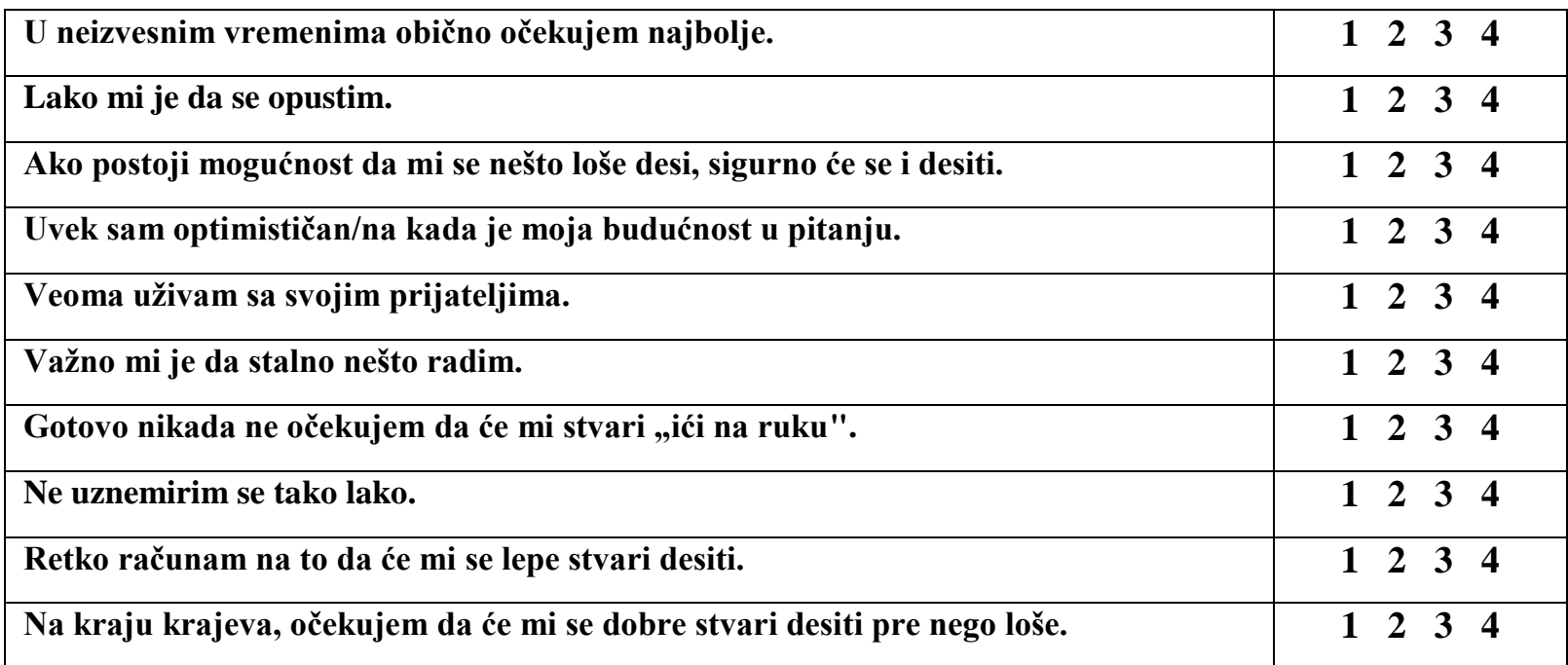


Molimo vas da navedete pet događaja iz VAŠE LIČNE PROŠLOSTI (autobiografskih događaja) koji vam PRVO PADNU NAPAMET. Nemojte mnogo razmišljati, navedite događaje kojih se prvo setite u ovom trenutku, bez selekcije. Navedite ih u formi teza, ne duže od jedne rečenice:

1.

2.

3.

4.

Sada uz svaki navedeni događaj upišite + , - ili 0 u zavisnosti od toga da li ga pamtite kao pozitivan (uz njega vezujete pozitivna osećanja), negativan (vezujete negativna osećanja) ili neutralan (ne vezujete ni pozitivna ni negativna osećanja).

Sledećih nekoliko pitanja popunjavate sami ili u saradnji sa eksperimentatorom (dobićete usmeno uputstvo). Pitanja se odnosi na test koji ste elektronski popunjavali u prvoj fazi eksperimenta. Molimo vas da odgovorite na sva pitanja, onako kako se sećate.

Vaš skor na prvom delu testa bio je :

Vaš skor na drugom delu testa bio je :

Vaš skor na trećem delu testa bio je :

Vaš ukupan skor na testu bio je :

HVALA NA SARADNJI! 


\section{Baterija korišćena u Eksperimentu 4}

(druga strana, pošto je prva identična)

Molimo vas da navedete pet događaja iz VAŠE LIČNE PROŠLOSTI (autobiografskih događaja) koji vam PRVO PADNU NAPAMET. Nemojte mnogo razmišljati, navedite događaje kojih se prvo setite u ovom trenutku, bez selekcije. Navedite ih u formi teza, ne duže od jedne rečenice:

1.

2.

3.

4.

5.

Sada uz svaki navedeni događaj upišite +, - ili 0 u zavisnosti od toga da li ga pamtite kao pozitivan (uz njega vezujete pozitivna osećanja), negativan (vezujete negativna osećanja) ili neutralan (ne vezujete ni pozitivna ni negativna osećanja).

Setite se sada testa opšte kulture koji ste popunjavali (ili pregledali) u prvom delu ispitivanja.

Koliko je u njemu otprilike bilo tačnih odgovora? Upišite broj, onako kako se vi sećate:

Molim vas navedite barem tri zadatka iz tog testa, onako kako se sećate:

a.

b.

c.

d.

e. 


\section{Baterija korišćena u Eksperimentu 5}

Molimo Vas da odvojite malo vremena i popunite list koji je pred vama.

U pitanju je naučno istraživanje, i svi podaci biće korišćeni isključivo u naučne svrhe. Nemojte previše razmišljati, odgovarajte u skladu sa onim što je vaš prvi osećaj.

Razmislite o sebi i svojim uobičajenim osećanjima.

(Zaokružite podeok na skali koji odražava vaše uobičajeno raspoloženje. Na primer, ako se nešto češće osećate umorno nego odmorno, zaokružite 5. Ako se uvek osećate veoma odmorno, zaokružite 1).

Procenite na svakoj od skala:

$\begin{array}{rllllllll}\text { Odmorno } & 1 & 2 & 3 & 4 & 5 & 6 & 7 & \text { Umorno } \\ \text { Srećno } & 1 & 2 & 3 & 4 & 5 & 6 & 7 & \text { Nesrećno } \\ \text { Uspešno } & 1 & 2 & 3 & 4 & 5 & 6 & 7 & \text { Neuspešno } \\ \text { Moćno } & 1 & 2 & 3 & 4 & 5 & 6 & 7 & \text { Nemoćno } \\ \text { Voljeno } & 1 & 2 & 3 & 4 & 5 & 6 & 7 & \text { Nevoljeno } \\ \text { Zaštićeno } & 1 & 2 & 3 & 4 & 5 & 6 & 7 & \text { Nezaštićeno } \\ \text { Energično } & 1 & 2 & 3 & 4 & 5 & 6 & 7 & \text { Bez energije } \\ \text { Veselo } & 1 & 2 & 3 & 4 & 5 & 6 & 7 & \text { Tužno } \\ \text { Optimistično } & 1 & 2 & 3 & 4 & 5 & 6 & 7 & \text { Pesimistično } \\ \text { Vedro } & 1 & 2 & 3 & 4 & 5 & 6 & 7 & \text { Neraspoloženo }\end{array}$

Pred vama se nalazi niz tvrdnji koje opisuju kako sebe doživljavate. Pročitajte svaku tvrdnju, i zaokružite 1-ako se uopšte ne slažete, 2-ako se uglavnom ne slažete, 3-ako se uglavnom slažete i 4-ako se sasvim slažete:

\begin{tabular}{|l|c|}
\hline Uopšteno govoreći, zadovoljan/na sam sobom. & 1234 \\
\hline Želeo/la bih da imam više samopoštovanja. & 1234 \\
\hline Osećam da ima puno toga čime bih se mogao/la ponositi. & 1234 \\
\hline Ponekad se osećam potpuno beskorisno. & 1234 \\
\hline Sposoban/na sam da radim i izvršavam zadatke jednako uspešno kao i većina drugih. & 1234 \\
\hline S vremena na vreme osećam da ništa ne vredim. & 1234 \\
\hline Osećam da posedujem niz vrednih osobina. & 1234 \\
\hline Sve više sam uveren/a u to da jako malo vredim. & 1234 \\
\hline Mislim da vredim barem koliko i drugi ljudi. & 1234 \\
\hline Osećam da sam jednako sposoban/na kao i drugi ljudi & 1234 \\
\hline
\end{tabular}


Ocenite u kojoj meri se slažete sa datim tvrdnjama:

1-ako se uopšte ne slažete, 2 -ako se uglavnom ne slažete, 3 -ako se uglavnom slažete i 4 -ako se sasvim slažete:

\begin{tabular}{|l|r|}
\hline Stalo mi je do toga da imam dobre ocene u školi. & 1234 \\
\hline Ne mogu sebe da zamislim da se žalim na ocenu. & 1234 \\
\hline Imam razumevanja za ljude koji se žale ako nisu zadovoljni ocenom. & 1234 \\
\hline Dajem sve od sebe da budem dobar učenik. & 1234 \\
\hline
\end{tabular}

Razmislite na trenutak o tome šta očekujete od budućnosti. Ocenite u kom stepenu se slažete sa sledećim tvrdnjama: zaokružite 1-ako se uopšte ne slažete, 2-ako se uglavnom ne slažete, 3-ako se uglavnom slažete i 4 -ako se sasvim slažete:

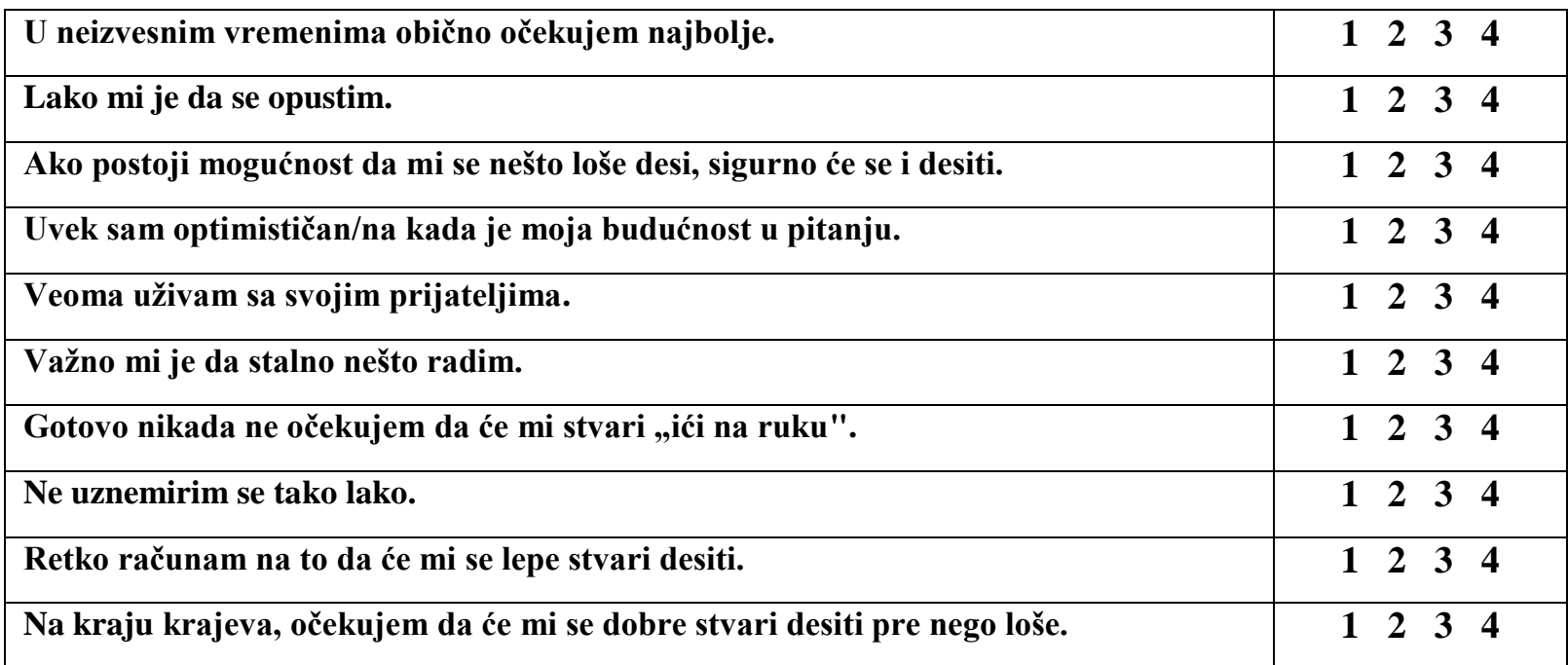


Molimo vas da navedete pet događaja iz VAŠE LIČNE PROŠLOSTI (autobiografskih događaja) koji vam PRVO PADNU NAPAMET. Nemojte mnogo razmišljati, navedite događaje kojih se prvo setite u ovom trenutku, bez selekcije. Navedite ih u formi teza, ne duže od jedne rečenice:
f.
g.
h.
i.
j.

Sada uz svaki navedeni događaj upišite +, - ili 0 u zavisnosti od toga da li ga pamtite kao pozitivan (uz njega vezujete pozitivna osećanja), negativan (vezujete negativna osećanja) ili neutralan (ne vezujete ni pozitivna ni negativna osećanja).

Pokušajte sada da se prisetite novinskog teksta koji ste čitali u prvom delu eksperimenta. U njemu su navođene neke osobine koje su u istraživanju utvrđene za mlade u Srbiji i Rumuniji. Navedite sve osobine kojih se sećate.

Mladi u Srbiji su:

Mladi u Rumuniji su:

Dalje su u tekstu navođeni rezultati na različitim testovima koje su u proseku postigli mladi u Srbiji i Rumuniji. Popunite donju tabelu, onako kako se sećate:

\begin{tabular}{|l|l|l|}
\hline & \multicolumn{1}{|c|}{ Srbija } & \multicolumn{1}{c|}{ Rumunija } \\
\hline $\begin{array}{l}\text { Verbalne sposobnosti } \\
\text { (razvijenost jezika, razumevanje) }\end{array}$ & Procenat rešenih zadataka & Procenat rešenih zadataka \\
\hline $\begin{array}{l}\text { Numeričke sposobnosti (računanje, } \\
\text { nastavljanje nizova) }\end{array}$ & & \\
\hline Prostorni odnosi & & \\
\hline Rešavanje logičkih zadataka & & \\
\hline Ukupan skor & & \\
\hline
\end{tabular}

Proverite da li ste popunili sve ćelije u tabeli.

HVALA NA SARADNJI!!! 
- PRILOG 2 -

\section{Rezultati pretestiranja}


Tabela 2.1

Procena značaja različitih sposobnosti

\begin{tabular}{lll}
\hline Sposobnosti & $\mathrm{M}$ & $\mathrm{SD}$ \\
\hline Opšta intelektualna sposobnost, inteligencija & 8.7 & 1.2 \\
Verbalna sposobnost & 8.1 & 2.4 \\
Numerička sposobnost & 7.8 & 1.8 \\
Sposobnost snalaženja u prostoru & 6.8 & 2.2 \\
Koordinacija pokreta & 6.1 & 2.5 \\
Fine motoričke sposobnosti & 5.8 & 2.4 \\
Vizuelno-perceptivna sposobnost & 5.2 & 2.6 \\
Dobra kratkoročna memorija & 5.1 & 1.8 \\
Osetljivo čulo ukusa & 4.2 & 2.3 \\
Talenat za ples & 3.8 & 2.2 \\
Osetljivo čulo mirisa & 3.6 & 2.5 \\
\hline
\end{tabular}


Tabela 2.2

Učestalost navođenja poželjnih i nepoželjnih osobina ličnosti

\begin{tabular}{|c|c|c|c|}
\hline Poželjne osobine ličnosti & $\mathrm{f}$ & Nepoželjne osobine ličnosti & $\mathrm{f}$ \\
\hline iskrenost & 37 & neiskrenost & 30 \\
\hline društvenost, komunikativnost & 33 & sebičluk & 27 \\
\hline duhovitost & 25 & ljubomora, zavist & 26 \\
\hline poštenje & 20 & agresivnost & 25 \\
\hline vernost, lojalnost, privrženost & 17 & lenjost & 25 \\
\hline tolerantnost & 17 & licemerje, dvoličnost & 24 \\
\hline empatičnost & 16 & pohlepa & 19 \\
\hline inteligencija & 16 & nekomunikativnost & 17 \\
\hline ambicioznost & 16 & egocentričnost & 17 \\
\hline odgovornost & 15 & tvrdoglavost & 16 \\
\hline vrednoća & 15 & neodgovornost & 16 \\
\hline hrabrost & 14 & netolerantnost & 15 \\
\hline pristojnost, ljubaznost & 14 & bahatost & 15 \\
\hline požrtvovanost & 13 & prevrtljivost & 14 \\
\hline posvećenost & 12 & ljubomora & 13 \\
\hline fleksibilnost & 12 & gordost & 11 \\
\hline upornost & 11 & pesimizam & 11 \\
\hline snalažljivost & 11 & nesigurnost & 11 \\
\hline humanost & 10 & škrtost & 10 \\
\hline staloženost, smirenost & 10 & nedostatak ambicije & 10 \\
\hline kreativnost & 10 & nepouzdanost & 10 \\
\hline optimizam & 10 & kukavičluk & 9 \\
\hline brižnost & 9 & razmaženost & 9 \\
\hline samostalnost & 9 & sujeta & 9 \\
\hline
\end{tabular}




\section{-PRILOG 3-}

Stimulus materijal 


\section{Test sposobnosti korišćen u Ogledu 2}
a)
b)
d)

c)

3
a) 3
b) 3
c) 3
d)

a)

b)

c)

d)

e)

Bure je 27 puno. Koliko

a)

b)

c)

d)

a)

b)

c)

d) 
a)

b)

c)

d)

a) $1 / 5$

b) $1 / 20$

c) $1 / 25$

d) $1 / 50$

e) $1 / 200$

a)

b)

c)

d)

e)

a)

b)

c)

d)

e) 
a)

b)

c)

d)

a)

b)

c)

d)

a)

b)

c)

d)

a)

b)

c)

d)

a)

b)

c)

d) 

a)
b)
c)
d)

200100300150450
a) 350
b) 75
c) 225
d) 250

Sta od navedenog najbolje simbolizuje niz:

a)

b)

c)

d)

e)

Šta od navedenog najbolje simbolizuje niz:

a)

b)

c)

d)

e)

Šta od navedenog najbolje simbolizuje niz:

a)

b)

c)

d)

e) 
Šta od navedenog najbolje simbolizuje niz:

a)

b)

c)

d)

e)

Šta od navedenog najbolje simbolizuje niz:

A.

B.

C.

D.

E. 


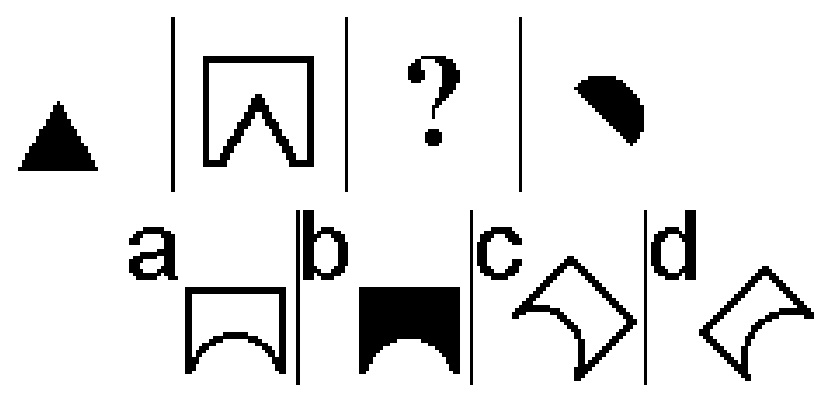

(ㅇ) ? 回

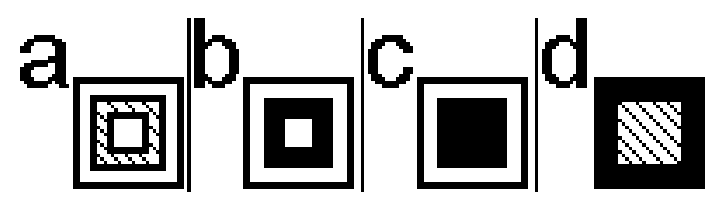

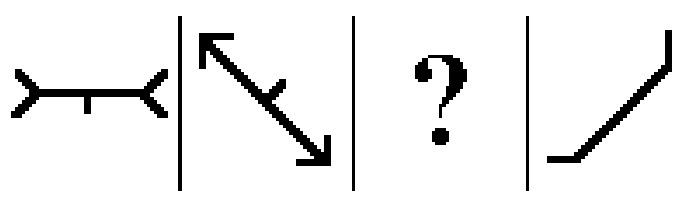

$a /\left.\left.r^{b}\right|^{c}\right|^{d} u$

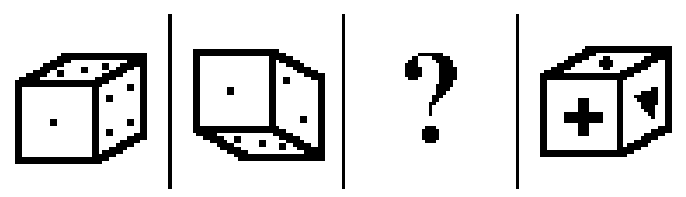

$\left.\left.\stackrel{a}{b}\right|_{+\infty} ^{c}\right|^{d}$ 

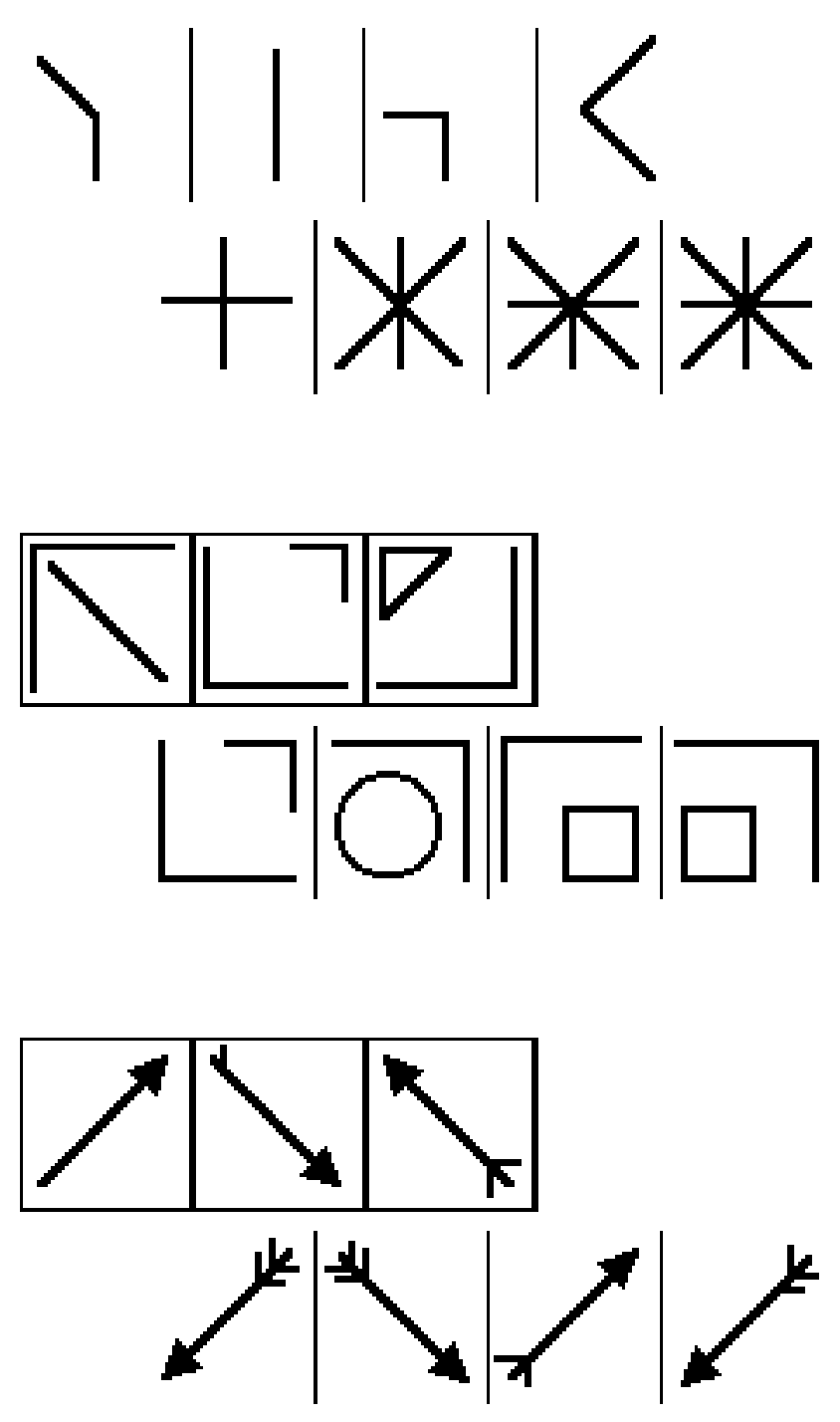


\section{Test "socijalno-kognitivnih" sposobnosti korišćen u Ogledu 3}

Pred vama se nalazi test socijalne kognicije, koji procenjuje sposobnost prepoznavanja emocionalnog stanja drugih ljudi, osetljivost na socijalni kontekst i sposobnost predviđanja reakcija pojedinaca ili socijalnih grupa.

Test se sastoji iz tri bloka pitanja i pre svakog od njih će biti prikazano uputstvo. Molimo Vas da pažljivo pročitate uputstva i odgovorite na svako pitanje. Radite brzo - najbolje je da ne razmišljate puno, već da se oslonite na prvi osećaj.

Uputstvo za prvi blok:

U sledećem bloku pitanja biće vam izloženi nalazi različitih istraživanja sa ponuđenim odgovorima od kojih je samo jedan tačan. Vaš zadatak je da, na osnovu osećaja (podrazumeva se da ne znate tačne nalaze) procenite koji bi odgovor mogao biti tačan. Odgovarajte pritiskom na taster $a, b, c, d$, ili $e$. Radite brzo.

Koliko puta je veći prosečan broj razvoda među parovima različite veroispovesti u poređenju sa brojem razvoda parova iste veroispovesti?
a. Nema razlike
b. 2 puta veći
c. 3 puta veći
d. 4 puta veći

Koliko procenata muškaraca homoseksualne orijentacije javno saopšti (roditeljima, prijateljima) tu činjenicu?
a. Manje od $10 \%$
b. $10 \%-20 \%$
c. $21 \%-30 \%$
d. Preko $30 \%$

Koliko puta je prosečan broj partnera među LGBT populacijom veći nego među heteroseksualnom populacijom?
a. Nema razlike
b. 2 puta veći
c. 3 puta veći
d. 4 puta veći 
Koliko adolescenata u Srbiji tvrdi da je ozbiljno razmišljalo o samoubistvu?
a. Manje od $10 \%$
b. $10 \%-20 \%$
c. $21-30 \%$
d. Preko $30 \%$

Koji je prosečan uzrast u kome mladi u Srbiji postaju seksualno aktivni, na osnovu podataka iz 2008. godine?
a. 13 godina
b. 14 godina
c. 15 godina
d. 16 godina
e. 17 godina

Koji je procenat bračnih parova u kome jedan od partnera ne prevari drugog tokom prvih 5 godina braka?
a. Manje od $10 \%$
b. $10 \%-20 \%$
c. $21 \%-30 \%$
d. $31 \%-40 \%$
e. Preko $50 \%$

Najveći je broj recidivista (ponovnih prestupnika) među zatvorenicima optuženim za krivično delo:
a. Silovanja
b. Krađe
c. Prevare
d. Nanošenja teških telesnih povreda

Koji broj odraslih osoba pati od neke vrste bezrazložnog straha (fobije)?
a. Svaka treća
b. Svaka četvrta
c. Svaka deseta
d. Svaka dvadeseta 


\section{Uputstvo za drugi blok:}

Ova sekcija testa sastoji se iz 8 sažetih profila po jednog mladića i devojke koji su u vezi, koji se zasnivaju na stvarnim podacima iz psihološke procene. Pročitajte svaki par opisa i onda procenite na osnovu datih informacija da li je par ostao u vezi duže od jedne godine ili ne.

Odgovore dajete pritiskom na tastere E (za DA) i I (za NE).

Radite brzo.

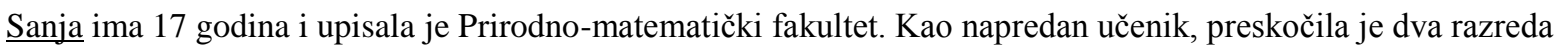
u osnovnoj školi, a za sobom ima već dve nagrade sa matematičkih olimpijada. Izuzetno je savesna i stroga, pre svega prema sebi. Na fakultetu je najmlađa od svih studenata, i uz to prilično sitne građe. Sanja godinama pati od socijalnih fobija, pa joj ovakvo okruženje deluje gotovo zastrašujuće. Rešava ovu situaciju povlačenjem iz socijalnih kontakata i u potpunosti se posvećuje svom radu.

Dragan ima 22 godine i najstariji je sin u petočlanoj porodici. Oba roditelja su izgubila posao, pa on još od srednje škole radi dva posla. Radi kao računovođa u banci preko dana, dok uveče radi za šankom u jednom kafiću. Trudi se da što skromnije živi i da bude oslonac roditeljima. Slobodno vreme provodi igrajući košarku sa drugarima iz naselja i u druženju sa kolegama sa posla. Dragan je veoma emotivno receptivan i brine za dobrobit drugih: pravi prijatelj na koga se uvek može osloniti.

\section{Da li je par ostao u vezi duže od jedne godine ili ne?}

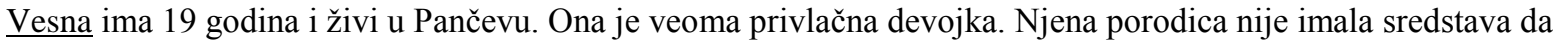
joj plaća školarinu na fakultetu, pa je Vesna počela da radi u restoranu. Iako to smatra pomalo ponižavajućim poslom, želi sama da se izdržava. Veoma je samosvesna i ima potrebu da bude nezavisna. U slobodno vreme traga za intelektualnom stimulacijom - čita knjige, posećuje muzeje i ide na časove pisanja. Vesna je uzdržana u kontaktu sa ljudima - ne oseća se dobro u velikim grupama ljudi i više voli prisnije odnose sa odabranima.

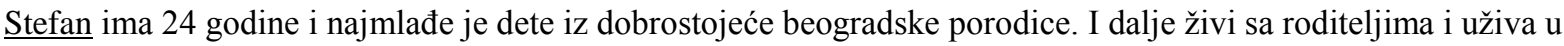
njihovoj pažnji. Ne mari suviše za ljude, već od njih očekuje da ispune njegove potrebe. Stefan redovno vežba i veoma brine o utisku koji ostavlja. Ranije je svoje slobodno vreme posvećivao bavljenju raznim sportovima. Međutim, od skora je upisao master studije i počeo ozbiljno da razmišlja o budućoj karijeri. Stefanove sposobnosti nisu u potpunom skladu sa aspiracijama, pa je shvatio da će morati jako da se potrudi ako želi da uspe.

Da li je par ostao u vezi duže od jedne godine ili ne?

Dijana dolazi iz Herceg-Novog i na drugoj je godini fakulteta. Krupne je građe, ali uvek veoma doterana i Ženstveno obučena. Ona je prilično opitmistična i ekstravertna osoba, koja sa lakoćom sklapa prijateljstva. Studira ekonomiju i planira da jednog dana postane menadžer u nekoj velikoj firmi. Znajući da je to ambiciozan plan, veoma je savesna u vezi sa fakultetskim obavezama. Dijana ima veoma jasnu listu prioriteta u svom životu i živi u skladu sa njima: na prvom mestu joj je porodica, zatim prijatelji i fakultet.

Dejan je 24-godišnji student master studija psihologije. On je srednje dete iz jedne novosadske porodice. Veoma je energičan i posvećen svemu što radi. Izuzetno je promišljen i organizovan - pridržava se preciznog dnevnog 
rasporeda: svakog dana trenira, sprema zdravke obroke i intenzivno uči, pošto ima visoke akademske aspiracije. Kako mu ovakav raspored oduzima gotovo sve raspoloživo vreme, njegov društveni život često trpi.
Da li je par ostao u vezi duže od jedne godine ili ne?
DA NE

Biljana ima 23 godine i dolazi iz Niša. Veoma je aktivna, energična i ima visoko samopouzdanje. Od kada je završila srednju školu radi kao sekretarica u advokatskoj kancelariji. Iako je veoma inteligentna, nikada nije imala visok nivo aspiracija. Ne interesuje je da ostvaruje svoje intelektualne potencijale, već svu svoju energiju usmerava na druženje, šoping i organizovanje velikih žurki. Izrazito je ekstravertna - ima ogroman broj prijatelja i u svakom društvu je u centru pažnje. Asertivna je i dominantna u bliskim odnosima sa ljudima.

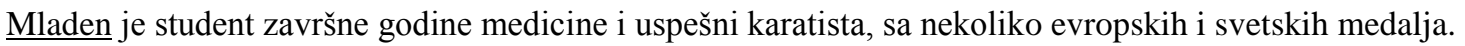
Zadovoljan je svojim fizičkim izgledom a i devojke smatraju da je vrlo privlačan. On je spontana i ležerna osoba, hedonistički nastrojena: uvek je raspoložen za druženje i zabavu. Međutim, imidž sportiste i lepotana je počeo da ga frustrira - želi da ljudi počnu da ga doživljavaju kao inteligentnog i sposobnog. Sprema se da postane doktor i želi da se posveti svojoj profesiji.

\section{Da li je par ostao u vezi duže od jedne godine ili ne?}

Tara ima 22 godine i dolazi iz Novog Sada. Jedino je dete iz bogate porodice. Njena akademska postignuća su zadivljujuća. Proglašena je za studenta generacije na molekularnoj biologiji i već je objavila nekoliko radova u vrhunskim časopisima. Međutim, njeno funkcionisanje na socijalnom planu nije jednako dobro. Njen odnos sa ljudima je obojen ambivalentnim osećanjima. Više voli da sama organizuje svoje vreme, jer se teško uklapa u aktivnosti grupe ljudi. U grupi se lako zbuni i ostavlja utisak nekompetentne osobe.

Filip ima 30 godina i živi u Novom Sadu. Iako je prilično zgodan, često je neobrijan i izgleda neuredno. Roditelji su insistirali da završi prava, ali on oseća da ga taj poziv sputava. Sklon je imaginaciji, nekonvencionalnom i eksperimentisanju sa novim idejama. Ima izraženu potrebu za nezavisnošću. Zato je napustio očevu advokatsku kancelariju i odlučio da se sprema za studije slikarstva. Nema stalnu devojku, a njegove veze obično ne traju duže od mesec dana.

\section{Da li je par ostao u vezi duže od jedne godine ili ne? $\quad$ DA NE}

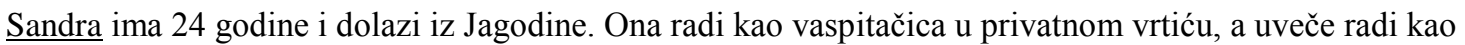
instruktorka aerobika. Oba posla je ispunjavaju i ona je zadovoljna sobom. Međutim, ona ima i pomalo potisnute potrebe za doživljavanjem novog i nepoznatog. Kada je bila mlađa, jedno vreme je živela kod tetke $u$ Francuskoj; to je iskustvo za koje kaže da ga nikada neće zaboraviti. Sandra je veoma empatična - ume da se sasluša ljude i da se saživi sa njihovim problemima. Koliko god obaveza imala, uvek nađe vremena za prijatelje.

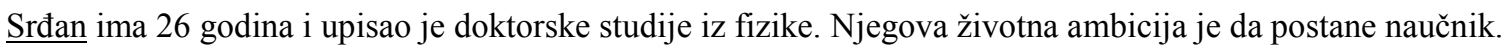
Ipak, nimalo ne liči na stereotipnu predstavu o naučniku sa debelim naočarima - prilično je privlačan - ima dugu kosu i moderno se oblači. Prezire konzervativne društvene norme i ideje. Odlikuje ga intelektualna radoznalost: kada ne sprovodi eksperimente u laboratoriji i ne proučava teoriju relativiteta, rado odlazi u neki muzej, pozorište ili gleda strane filmove. Ne voli velika društva, već teži da ostvari prisniji kontakt sa ljudima.
Da li je par ostao u vezi duže od jedne godine ili ne?
DA NE 


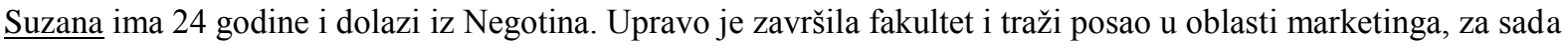
bezuspešno. Suzana je vrlo spontana i neposredna osoba, koja voli da se zabavlja. Nikada nije bila suviše dobar student i drago joj je da je završila fakultet. Nije preterano privlačna i ima višak kilograma, ali to ne smeta njenom samopouzdanju. Smatra da ima šta da ponudi i da ne treba gubiti vreme na ljude koji ne umeju da vide dublje od površine.

Bojan ima 22 godine i student je Vojne akademije. Jedva je položio prijemni iz matematike, ali je izvrstan sportista: juniorski šampion Evrope u džudou. Sada prilično teško izlazi na kraj sa zahtevima nekih predmeta. Bojan je okrenut ljudima i ima potrebu da je uvek okružen velikim brojem prijatelja. Pre nego što je upisao akademiju, plašio se da će njegove kolege biti isuviše konzervativne i da će njegov socijalni život utihnuti. Međutim, Bojan je shvatio da je njegov strah bio neopravdan. Shvatio je da veliki grad pruža mnogo mogućnosti za upoznavanje novih ljudi.

Da li je par ostao u vezi duže od jedne godine ili ne?

DA $\quad \mathrm{NE}$

Lena ima 22 godine i na završnoj je godini studija književnosti. Trenutno živi u Beogradu, ali se njena porodica puno selila po čitavoj Evropi. Živela je u Češkoj i Nemačkoj i tečno govori tri jezika. Izuzetno je privlačna, ali ne želi da se oslanja na svoj izgled. Veoma je inteligentna i analitična i želi da ove osobine istakne u prvi plan, a ne da bude viđena kao površna lepotica. Međutim, ona nije posebno savesna - redovno doživljava konflikte između želje da se druži i zabavlja i obaveze da se posveti učenju.

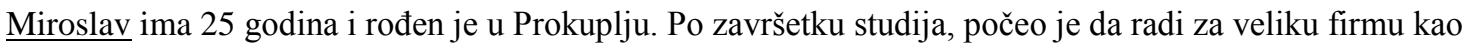
građevinski inženjer. Iako već godinama živi u Beogradu, oseća da se nikada nije u potpunosti prilagodio. Veliki grad čini da se oseća nesigurnim u sebe i ponekad čezne za zaštićenom porodičnom sredinom. Nije uspeo da pronađe puno prijatelja i oseća se prilično usamljeno. Pošto ne podnosi lenčarenje, trudi se da se bori sa usamljenošću raznim hobijima - svakog dana ide na trčanje i puno čita. Sve češće odlazi u crkvu i interesuje se za religiju

Da li je par ostao u vezi duže od jedne godine ili ne?

DA NE 


\section{Uputstvo za treći blok:}

U poslednjem bloku pitanja princip odgovaranja je kao u prvom: biće vam izloženi nalazi različitih istraživanja sa ponuđenim odgovorima od kojih je samo jedan tačan. Vaš zadatak je da, na osnovu osećaja (podrazumeva se da ne znate tačne nalaze) procenite koji bi odgovor mogao biti tačan. Odgovarajte pritiskom na taster $a, b, c, d$, ili $e$. Radite brzo.

Koji je procenat osoba koje svakoga dana barem jednom slažu?
a. $10 \%$
b. $30 \%$
c. $50 \%$
d. $80 \%$

Koliko je ljudi koji su u svom životu ukrali nešto iz prodavnice?
a. 2 od 10
b. 3 od 10
c. 5 od 10
d. 9 od 10

Koliko u proseku dnevno kalorija unese osoba obolela od anoreksije?
a. Manje od 100
b. $100-500$
c. 501-1000
d. Preko 1000

Koji procenat mladih (15-20 godina) u Srbiji planira da ima decu u budućnosti?
a. $10 \%$
b. $30 \%$
c. $70 \%$
d. $90 \%$ 
Koji procenat mladića u Srbiji odobrava fizičko nasilje nad partnerkom "ako ona to zasluži"?
a. $10 \%$
b. $30 \%$
c. $70 \%$
d. $90 \%$

Koliko se ljudi u proseku odaziva direktnim apelima za dobrovoljno davanje krvi?
a. Svaki petstoti
b. Svaki stoti
c. Svaki pedeseti
d. Svaki deseti

Koliki je procenat ljudi starijih od 18 godina koji se, prema istraživanjima, u celom životu nijednom nisu napili?
a. Manje od $1 \%$
b. $1 \%-5 \%$
c. $6-10 \%$
d. Više od $10 \%$

Koliko je među heteroseksualnom populacijom osoba koje su imale barem jedno homoseksualno iskustvo?
a) Manje od 5\%
b) $6 \%-10 \%$
c) $11 \%-20 \%$
d) Više od $20 \%$ 


\section{Test opšte kulture korišćen u Ogledu 4.2}

Pažljivo pročitaj pitanja pa zaokruži ili upiši tačan odgovor.

1. Evropsku Uniju čini:
a. 18 zemalja
b. 22 zemlje
c. 25 zemalja
d. 27 zemalja
e. 28 zemalja

2. Ko je autor knjige "Ispovesti varalice Feliksa Krula"?
a. Robert Ladlam
b. Džon LeKare
c. Tomas Man
d. Paolo Kueljo
e. Niko od navedenih

3. Dau Džons je:
a. korejski akcioni glumac
b. berzanski indeks
c. vrh u Andima
d. oboljenje tiroidne žlezde
e. ništa od navedenog

4. Generičko ime za aspirin je:
a. askorbinska kiselina
b. acetil salicilna kiselina
c. ibuprofen
d. paracetamol
e. ništa od navedenog

5. Kohov bacil je izazivač:
a. tetanusa
b. tuberkuloze
c. multiple skleroze
d. kuge
e. nijedne od navedenih bolesti

6. Beta karoten je izvor vitamina:
a. A
b. B
c. C
d. D 
7. Jozef Hajdn je:
a. pisac
b. kompozitor
c. naučnik
d. geografski istraživač
e. ništa od navedenog

8. Ben Kingsli je 1982 osvojio Oskara za film:

1. Odiseja u svemiru

2. Šindlerova lista

3. Vozeći gospođicu Dejzi

4. Gandi

5. Nijedan od navedenih

9. Koje svemirsko telo se više ne smatra planetom nakon 2006 ?

10. Na kog američkog predsednika je izvršen atentat 1865 ?

11. Ko je napisao "Životinjsku farmu"?

12. Koja planeta u Sunčevom sistemu je nazvana po rimskom bogu rata?

13. Sauna je poreklom iz:

14. Koje kontinente razdvaja Beringov moreuz?

\begin{tabular}{|l|c|}
\hline 15. Artful Dodžer je lik iz romana Čarlsa Dikensa. & DA NE \\
\hline 16. SIDA je akronim za "stečena bolest imunodeficijencije". & DA NE \\
\hline 17. Nikola Tesla je izumeo jednosmernu struju. & DA NE \\
\hline 18. Mont Erebus je aktivan vulkan. & DA NE \\
\hline 19. Geta je deo tradicionalne japanske odeće. & DA NE \\
\hline 20. Srebro je teže od zlata. & DA NE \\
\hline
\end{tabular}


Ključ za ocenjivanje
a. d
b. c
c. b
d. b
e. b
f. a
g. b
h. d

i. Pluton

j. Abrahama Linkolna

k. Džordž Orvel

1. Mars

m. Finske

n. Aziju i Severnu Ameriku

o. Da

p. Da

q. $\mathrm{Ne}$

r. Da

s. Da

t. $\mathrm{Ne}$ 


\section{Članci korišćeni u Ogledu 5, obe verzije}

Adolescenti na zapadnom Balkanu- gde se nalazi Srbija?

06.Apr.2010, Izvor: Mondo

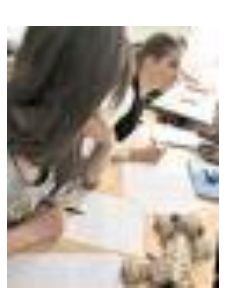

U najnovijoj studiji Evropske omladinske fondacije istraživane su sposobnosti i osobine ličnosti srednjoškolaca na Zapadnom Balkanu. U ovom istraživanju učestvovalo je 20000 šesnaestogodišnjaka, a u Srbiji ga je sprovodio Institut za psihologiju. U periodu od 12. aprila do 6. maja 2009, u Srbiji su ukupno testirana 3402 učenika iz 168 škola, a metodom slučajnog uzorka u svakoj školi je u proseku izabrano 34 učenika koji su pristupili testiranju. Pravila testiranja bila su jednaka u svim zemljama učesnicama: test je trajao dva sata, a učenici su morali da ostanu u učionici do samog kraja nezavisno od toga kada su ispunili test. Istraživanje "Mladi u Evropi" se u Evropskoj Uniji sprovodi svake tri godine, počevši od 2000, a ovo je prvi put da je studija uključila i zemlje Zapadnog Balkana (Hrvatsku, BiH, Makedoniju, Srbiju, Rumuniju i Bugarsku).

Studija je sprovedena sa ciljem da se upoznaju specifičnosti mladih iz ovog regiona, kako bi se obrazovni sistem i medijska komunikacija bolje prilagodili njihovim potrebama. Do sada su analizirani rezultati iz dve susedne zemlje: Srbije i Rumunije. Istraživači koji su sprovodili studiju ističu da podaci ne treba da služe za upoređivanje među zemljama, već za pronalaženje sličnosti, zajedničkih interesovanja i mogućnosti za regionalne akcije. Za mlade iz Srbije testovi ličnosti utvrdili su da su društveni, uporni, kreativni, skloni ljubomori, neambiciozni i nesigurni u sebe. Mladi Rumuni i Rumunke su odgovorni, staloženi I kreativni, nekomunikativni, gordi i pesimistično raspoloženi (u ovom odeljku navedeni su samo rezultati koji značajno odstupaju od prosečnih). Što se tiče testova intelektualnih sposobnosti, rezultati studije pokazali su sledeće specificnosti (prikaz u tabeli):

\section{Srbija}

Albanija

Procenat rešenih zadataka

Procenat rešenih zadataka

Verbalne sposobnosti

54

45

(razvijenost jezika, razumevanje)

Numeričke sposobnosti

65

67

(računanje, nastavljanje nizova)

Prostorni odnosi

62

55

Rešavanje logičkih zadataka

36

49

Ukupan skor

59

56

Za celokupne rezultate istraživanja moraćemo da čekamo još gotovo šest meseci, jer pravila nalažu da se rezultati šalju u Brisel na kompletnu obradu, a rezutati za sve države se zatim istovremeno objavljuju u čitavoj Evropi. Zvaničnici u Ministarstvu omladine i sporta ističu da će im rezultati ove studije biti od neprocenjive važnosti u unapredjivanju Nacionalne strategije za mlade, dokumenta usvojenog krajem 2008 godine. Ciljevi strategije su da odredi ulogu države prema mladima ohrabri ih u učešću u društvu, izgradi sistem informisanja mladih na svim nivoima, obezbedi prava na jednake šanse i podstiče izuzetna dostignuća mladih u svim oblastima. 
Adolescenti na zapadnom Balkanu- gde se nalazi Srbija?

06.Apr.2010, Izvor: Mondo

U najnovijoj studiji Evropske omladinske fondacije istraživane su sposobnosti i osobine ličnosti srednjoškolaca na Zapadnom Balkanu. U ovom istraživanju učestvovalo je 20000 šesnaestogodišnjaka, a u Srbiji ga je sprovodio Institut za psihologiju. U periodu od 12. aprila do 6. maja 2009, u Srbiji su ukupno testirana 3402 učenika iz 168 škola, a metodom slučajnog uzorka u svakoj školi je u proseku izabrano 34 učenika koji su pristupili testiranju. Pravila testiranja bila su jednaka u svim zemljama učesnicama: test je trajao dva sata, a učenici su morali da ostanu u učionici do samog kraja nezavisno od toga kada su ispunili test. Istraživanje "Mladi u Evropi" se u Evropskoj Uniji sprovodi svake tri godine, počevši od 2000, a ovo je prvi put da je studija uključila i zemlje Zapadnog Balkana (Hrvatsku, BiH, Makedoniju, Srbiju, Rumuniju i Bugarsku).

Studija je sprovedena sa ciljem da se upoznaju specifičnosti mladih iz ovog regiona, kako bi se obrazovni sistem i medijska komunikacija bolje prilagodili njihovim potrebama. Do sada su analizirani rezultati iz dve susedne zemlje: Srbije i Rumunije. Istraživači koji su sprovodili studiju ističu da podaci ne treba da služe za upoređivanje među zemljama, već za pronalaženje sličnosti, zajedničkih interesovanja i mogućnosti za regionalne akcije. Za mlade iz Srbije testovi ličnosti utvrdili su da su odgovorni, staloženi, kreativni, nekomunikativni, gordi i pesimistično raspoloženi . Mladi Rumuni i Rumunke su društveni, uporni, kreativni, skloni ljubomori, neambiciozni i nesigurni u sebe.

(u ovom odeljku navedeni su samo rezultati koji značajno odstupaju od prosečnih). Što se tiče testova intelektualnih sposobnosti, rezultati studije pokazali su sledeće specificnosti (prikaz u tabeli):

\begin{tabular}{lcc} 
& Srbija & Albanija \\
\hline & Procenat rešenih zadataka & Procenat rešenih zadataka \\
Verbalne sposobnosti & 45 & 54 \\
(razvijenost jezika, razumevanje) & & \\
Numeričke sposobnosti & 67 & 65 \\
(računanje, nastavljanje nizova) & & 62 \\
Prostorni odnosi & 55 & 36 \\
Rešavanje logičkih zadataka & 49 & 59 \\
Ukupan skor & 56 & \\
\hline
\end{tabular}

Za celokupne rezultate istraživanja moraćemo da čekamo još gotovo šest meseci, jer pravila nalažu da se rezultati šalju u Brisel na kompletnu obradu, a rezutati za sve države se zatim istovremeno objavljuju u čitavoj Evropi. Zvaničnici u Ministarstvu omladine i sporta ističu da će im rezultati ove studije biti od neprocenjive važnosti u unapredjivanju Nacionalne strategije za mlade, dokumenta usvojenog krajem 2008 godine. Ciljevi strategije su da odredi ulogu države prema mladima ohrabri ih u učešću u društvu, izgradi sistem informisanja mladih na svim nivoima, obezbedi prava na jednake šanse i podstiče izuzetna dostignuća mladih u svim oblastima. 
-PRILOG 4- 
Tabela 4.1

Raspored ispitanika po eksperimentalnim grupama u Ogledu 1

\begin{tabular}{|c|c|c|c|}
\hline \multirow{4}{*}{$\begin{array}{l}\text { Godina studija } \\
\text { (memorijska dostupnost } \\
\text { dogadjaja) }\end{array}$} & \multirow{4}{*}{$\begin{array}{l}\text { Direktna (prva godina) } \\
\text { Naknadna (treća godina) }\end{array}$} & \multicolumn{2}{|c|}{ Instrukcija data za prisecanje } \\
\hline & & Bez instrukcije & "Što tačnije" \\
\hline & & 30 & 29 \\
\hline & & 25 & 21 \\
\hline
\end{tabular}

Tabela 4.2

Raspored ispitanika po eksperimentalnim grupama u Ogledu 2

\begin{tabular}{|c|c|c|c|c|c|}
\hline & & \multicolumn{4}{|c|}{ Usmeni ili pismeni retest (samopredstavljanje) } \\
\hline & & \multicolumn{2}{|c|}{ Usmeni } & \multicolumn{2}{|c|}{ Pismeni } \\
\hline & & Direktan ili & nadni retest & Direktan ili & nadni retest \\
\hline & & Direktan & Naknadni & Direktan & Naknadni \\
\hline \multirow{2}{*}{$\begin{array}{l}\text { Test vizuelne } \\
\text { percepcije ili } \\
\text { inteligencije } \\
\text { (uključenost) }\end{array}$} & $\begin{array}{l}\text { Test vizuelne percepcije } \\
\text { (slabije involvirajući) }\end{array}$ & 16 & 12 & 17 & 18 \\
\hline & $\begin{array}{l}\text { Test opštih kognitivnih } \\
\text { sposobnosti } \\
\text { (jače involvirajući) }\end{array}$ & 18 & 17 & 19 & 18 \\
\hline
\end{tabular}

Tabela 4.3

Raspored ispitanika po eksperimentalnim grupama u Ogledu 3

Usmeni ili pismeni retest (samopredstavljanje)

\begin{tabular}{lcccc} 
& \multicolumn{2}{c}{ Usmeni } & \multicolumn{2}{c}{ Pismeni } \\
\cline { 2 - 5 } & \multicolumn{2}{c}{ Direktan ili naknadni retest } & Direktan ili naknadni retest \\
\cline { 2 - 5 } Fidbek o uspehu & Direktan & Naknadni & Direktan & Naknadni \\
\cline { 2 - 5 } Fidbek o neuspehu & 20 & 22 & 19 & 18 \\
& 16 & 20 & 22 & 20
\end{tabular}


Tabela 4.4

ANOVA sa ponovljenim merama, standardizovani reziduali za grešku u izveštavanju o prijemnom i srednjoj školi kao zavisna varijabla

\begin{tabular}{|c|c|c|c|c|c|c|}
\hline & Zavisna varijabla & Suma kvadrata & df & AS kvadrata & $\mathrm{F}$ & $\mathrm{p}$ \\
\hline \multirow[t]{5}{*}{ Model } & St. rezidualza prvu godinu srednje škole & $3.84(\mathrm{a})$ & 3 & 1.28 & 1.304 & .277 \\
\hline & St. rezidualza drugu godinu srednje škole & 4.39(b) & 3 & 1.46 & 1.500 & .219 \\
\hline & St. rezidualza trecu godinu srednje škole & $8.18(\mathrm{c})$ & 3 & 2.73 & 2.905 & .038 \\
\hline & St. rezidualza cetvrtu godinu srednje škole & 7.13(d) & 3 & 2.38 & 2.504 & .063 \\
\hline & St. rezidualza broj poena na prijemnom & 12.93(e) & 3 & 4.31 & 4.832 & .003 \\
\hline \multirow[t]{5}{*}{ Isećak } & St. rezidualza prvu godinu srednje škole & .16 & 1 & .16 & .163 & 687 \\
\hline & St. rezidualza drugu godinu srednje škole & .18 & 1 & .18 & .185 & .668 \\
\hline & St. rezidualza trecu godinu srednje škole & .45 & 1 & .45 & .478 & .491 \\
\hline & St. rezidualza cetvrtu godinu srednje škole & .56 & 1 & .56 & .591 & .444 \\
\hline & St. rezidualza broj poena na prijemnom & 4.72E-005 & 1 & 4.72E-005 & .000 & .994 \\
\hline \multirow{5}{*}{$\begin{array}{l}\text { Memorijska } \\
\text { dostupnost }\end{array}$} & St. rezidualza prvu godinu srednje škole & .51 & 1 & .51 & .520 & .473 \\
\hline & St. rezidualza drugu godinu srednje škole & .09 & 1 & .09 & .091 & .763 \\
\hline & St. rezidualza trecu godinu srednje škole & .34 & 1 & .34 & .360 & .550 \\
\hline & St. rezidualza cetvrtu godinu srednje škole & .05 & 1 & .05 & .053 & .819 \\
\hline & St. rezidualza broj poena na prijemnom & 5.43 & 1 & 5.44 & 6.086 & .015 \\
\hline \multirow[t]{5}{*}{ Instrukcija } & St. rezidualza prvu godinu srednje škole & 3.14 & 1 & 3.14 & 3.200 & .077 \\
\hline & St. rezidualza drugu godinu srednje škole & 1.85 & 1 & 1.85 & 1.897 & .172 \\
\hline & St. rezidualza trecu godinu srednje škole & 4.49 & 1 & 4.49 & 4.779 & .031 \\
\hline & St. rezidualza cetvrtu godinu srednje škole & 6.78 & 1 & 6.78 & 7.148 & .009 \\
\hline & St. rezidualza broj poena na prijemnom & 1.28 & 1 & 1.28 & 1.435 & .234 \\
\hline \multirow[t]{5}{*}{ Godina * Instrukcija } & St. rezidualza prvu godinu srednje škole & .02 & 1 & .02 & .015 & .902 \\
\hline & St. rezidualza drugu godinu srednje škole & 1.58 & 1 & 1.58 & 1.618 & .206 \\
\hline & St. rezidualza trecu godinu srednje škole & 1.86 & 1 & 1.86 & 1.977 & .163 \\
\hline & St. rezidualza cetvrtu godinu srednje škole & .03 & 1 & .03 & .034 & .854 \\
\hline & St. rezidualza broj poena na prijemnom & 3.24 & 1 & 3.24 & 3.629 & .060 \\
\hline \multirow[t]{5}{*}{ Greška } & St. rezidualza prvu godinu srednje škole & 99.16 & 10 & .98 & & \\
\hline & St. rezidualza drugu godinu srednje škole & 98.61 & 10 & .98 & & \\
\hline & St. rezidualza trecu godinu srednje škole & 94.82 & 10 & .94 & & \\
\hline & St. rezidualza cetvrtu godinu srednje škole & 95.87 & 10 & .95 & & \\
\hline & St. rezidualza broj poena na prijemnom & 90.07 & 10 & .89 & & \\
\hline \multirow[t]{5}{*}{ Total } & St. rezidualza prvu godinu srednje škole & 103.00 & 10 & & & \\
\hline & St. rezidualza drugu godinu srednje škole & 103.00 & 10 & & & \\
\hline & St. rezidualza trecu godinu srednje škole & 103.00 & 10 & & & \\
\hline & St. rezidualza cetvrtu godinu srednje škole & 103.00 & 10 & & & \\
\hline & St. rezidualza broj poena na prijemnom & 103.00 & 10 & & & \\
\hline
\end{tabular}




\section{Tabela 4.5}

Korelacije greške preterivanja sa indikatorima psihološke adaptiranosti za uspešnu grupu Uspešna grupa, pozitivni fidbek

$\begin{array}{cccccc}\text { Zbir } & \text { Razlika } & & \text { Broj } & \text { Ukupan skor } & \text { Ukupan skor na } \\ \text { odstupanja za } & \text { saopstenog i } & \text { Ukupan skor na } & \text { pozitivnih/ } & \text { na skali } & \text { Rozenbergovoj } \\ \text { sve testove u } & \text { tacnog ukupnog } & \text { skali LOT } & \text { ukupan } & \text { Akademskih } & \text { skali } \\ \text { ogledima 2 i 3 } & \text { skora na testu u } & & \text { broj } & \text { ambicija } & \text { samopostovanja }\end{array}$

\begin{tabular}{|c|c|c|c|c|c|c|}
\hline $\begin{array}{l}\text { Zbir odstupanja za sve testove u } \\
\text { ogledima } 2 \text { i } 3\end{array}$ & - & & & & & \\
\hline $\begin{array}{l}\text { Razlika saopstenog i tacnog } \\
\text { ukupnog skora na testu u } \\
\text { ogledima } 2 \text { i } 3\end{array}$ & $.66(* *)$ & - & & & & \\
\hline Ukupan skor na skali LOT & .05 & .03 & - & & & \\
\hline $\begin{array}{l}\text { Broj pozitivnih/ukupan broj } \\
\text { secanja }\end{array}$ & -.18 & -.17 & $.28(*)$ & - & & \\
\hline $\begin{array}{l}\text { Ukupan skor na skali } \\
\text { Akademskih ambicija }\end{array}$ & .15 & .18 & $.31(* *)$ & .03 & - & \\
\hline $\begin{array}{l}\text { Ukupan skor na Rozenbergovoj } \\
\text { skali samopostovanja }\end{array}$ & .06 & -.01 & $.59(* *)$ & $.26(*)$ & .18 & - \\
\hline
\end{tabular}

\section{Tabela 4.6}

Korelacije greške preterivanja sa indikatorima psihološke adaptiranosti za neuspešnu grupu Neuspešna grupa, negativni fidbek

\begin{tabular}{|c|c|c|c|c|c|c|}
\hline & $\begin{array}{c}\text { Zbir odstupanja } \\
\text { za sve testove u } \\
\text { ogledima } 2 \text { i } 3\end{array}$ & $\begin{array}{c}\text { Razlika } \\
\text { saopstenog i } \\
\text { tacnog ukupnog } \\
\text { skora na testu u } \\
\text { ogledima } 2 \text { i } 3\end{array}$ & $\begin{array}{l}\text { Ukupan skor } \\
\text { na skali LOT }\end{array}$ & $\begin{array}{c}\text { Broj } \\
\text { pozitivnih/ } \\
\text { ukupan } \\
\text { broj } \\
\text { secanja }\end{array}$ & $\begin{array}{c}\text { Ukupan skor } \\
\text { na skali } \\
\text { Akademskih } \\
\text { ambicija }\end{array}$ & $\begin{array}{c}\text { Ukupan skor na } \\
\text { Rozenbergovoj } \\
\text { skali } \\
\text { samopostovanja }\end{array}$ \\
\hline $\begin{array}{l}\text { Zbir odstupanja za sve testove u } \\
\text { ogledima } 2 \text { i } 3\end{array}$ & - & & & & & \\
\hline $\begin{array}{l}\text { Razlika saopstenog i tacnog } \\
\text { ukupnog skora na testu u } \\
\text { ogledima } 2 \text { i } 3\end{array}$ & $.77(* *)$ & - & & & & \\
\hline Ukupan skor na skali LOT & .01 & .15 & - & & & \\
\hline $\begin{array}{l}\text { Broj pozitivnih/ukupan broj } \\
\text { secanja }\end{array}$ & -.06 & -.07 & $.42(* *)$ & - & & \\
\hline $\begin{array}{l}\text { Ukupan skor na skali } \\
\text { Akademskih ambicija }\end{array}$ & .04 & .03 & .14 & .02 & - & \\
\hline $\begin{array}{l}\text { Ukupan skor na Rozenbergovoj } \\
\text { skali samopostovanja }\end{array}$ & .12 & .19 & $.61(* *)$ & $.42(* *)$ & .07 & - \\
\hline
\end{tabular}


Tabela 4.7

Korelacije greške preterivanja sa indikatorima psihološke adaptiranosti, samo za aktere (Ogled 4.1)

$\begin{array}{ccccc}\text { Razlika } & \text { Ukupan skor na } & & \text { Broj } & \text { Ukupan skor na } \\ \text { saopstenog i } & \text { skali } & \text { Ukupan skor } & \text { pozitivnih/ } & \text { Rozenbergovoj } \\ \text { tacnog skora na } & \text { Akademskih } & \text { na skali LOT } & \text { ukupan } & \text { broj } \\ \text { prvom delu } & \text { ambicija } & & \text { secanja } & \text { samopostovanja } \\ \text { testa } & & & \text { secal }\end{array}$

\begin{tabular}{|c|c|c|c|c|c|}
\hline $\begin{array}{l}\text { Razlika saopstenog i tacnog } \\
\text { skora na prvom delu testa }\end{array}$ & - & & & & \\
\hline $\begin{array}{l}\text { Ukupan skor na skali } \\
\text { Akademskih ambicija }\end{array}$ & -.11 & - & & & \\
\hline Ukupan skor na skali LOT & .16 & -.21 & - & & \\
\hline $\begin{array}{l}\text { Broj pozitivnih/ukupan broj } \\
\text { secanja }\end{array}$ & -.26 & -.02 & -.01 & - & \\
\hline Ukupan skor na & & & & & \\
\hline $\begin{array}{l}\text { Rozenbergovoj skali } \\
\text { samopostovanja }\end{array}$ & -.06 & .05 & .28 & .09 & - \\
\hline
\end{tabular}

\begin{tabular}{|c|c|c|c|c|c|}
\hline & $\begin{array}{c}\text { Razlika } \\
\text { saopstenog i } \\
\text { tacnog skora } \\
\text { na drugom } \\
\text { delu testa }\end{array}$ & $\begin{array}{c}\text { Ukupan skor } \\
\text { na skali } \\
\text { Akademskih } \\
\text { ambicija }\end{array}$ & $\begin{array}{l}\text { Ukupan skor } \\
\text { na skali LOT }\end{array}$ & $\begin{array}{c}\text { Broj } \\
\text { pozitivnih/ } \\
\text { ukupan } \\
\text { broj } \\
\text { secanja }\end{array}$ & $\begin{array}{c}\text { Ukupan skor na } \\
\text { Rozenbergovoj } \\
\text { skali } \\
\text { samopostovanja }\end{array}$ \\
\hline $\begin{array}{l}\text { Razlika saopstenog i tacnog } \\
\text { skora na drugom delu testa }\end{array}$ & - & & & & \\
\hline $\begin{array}{l}\text { Ukupan skor na skali } \\
\text { Akademskih ambicija }\end{array}$ & .20 & - & & & \\
\hline Ukupan skor na skali LOT & -.04 & -.21 & - & & \\
\hline $\begin{array}{l}\text { Broj pozitivnih/ukupan broj } \\
\text { secanja }\end{array}$ & -.12 & -.02 & -.01 & - & \\
\hline $\begin{array}{l}\text { Ukupan skor na Rozenbergovoj } \\
\text { skali samopostovanja }\end{array}$ & -.26 & .05 & .28 & .09 & - \\
\hline
\end{tabular}


Tabela 4.8

Korelacije greške preterivanja sa indikatorima psihološke adaptiranosti, samo za aktere (Ogled 4.2)

\begin{tabular}{|c|c|c|c|c|c|}
\hline & $\begin{array}{c}\text { Razlika } \\
\text { saopstenog i } \\
\text { tacnog skora }\end{array}$ & $\begin{array}{c}\text { Ukupan skor } \\
\text { na skali } \\
\text { Akademskih } \\
\text { ambicija }\end{array}$ & $\begin{array}{l}\text { Ukupan skor } \\
\text { na skali LOT }\end{array}$ & $\begin{array}{c}\text { Broj } \\
\text { pozitivnih/ } \\
\text { ukupan } \\
\text { broj } \\
\text { secanja }\end{array}$ & $\begin{array}{c}\text { Ukupan skor na } \\
\text { Rozenbergovoj } \\
\text { skali } \\
\text { samopostovanja }\end{array}$ \\
\hline $\begin{array}{l}\text { Razlika saopstenog i } \\
\text { tacnog skora }\end{array}$ & - & & & & \\
\hline $\begin{array}{l}\text { Ukupan skor na skali } \\
\text { Akademskih ambicija }\end{array}$ & .23 & - & & & \\
\hline Ukupan skor na skali LOT & .08 & .21 & - & & \\
\hline $\begin{array}{l}\text { Broj pozitivnih/ukupan } \\
\text { broj secanja }\end{array}$ & .12 & .30 & .15 & - & \\
\hline Ukupan skor na & & & & & \\
\hline $\begin{array}{l}\text { Rozenbergovoj skali } \\
\text { samopostovanja }\end{array}$ & .27 & .23 & $.69(* *)$ & .20 & - \\
\hline
\end{tabular}


Faktorska analiza instrumenata

\section{Skala dominantnog raspoloženja}

Tabela 4.9

Ukupna objašnjena varijansa

\begin{tabular}{ccccccc}
\hline Komponenta & \multicolumn{5}{c}{ Svojstvene vrednosti } & \\
\hline & Total & \% varijanse & Kumulativni \% & Total & \% varijanse & Kumulativni \% \\
\hline 1 & 5.01 & 50.13 & 50.13 & 5.01 & 50.13 & 50.13 \\
2 & 1.09 & 10.88 & 61.01 & 1.09 & 10.88 & 61.01 \\
3 & .92 & 9.25 & 70.27 & & & \\
4 & .72 & 7.21 & 77.48 & & & \\
5 & .57 & 5.66 & 83.14 & & & \\
6 & .46 & 4.60 & 87.74 & & & \\
7 & .41 & 4.05 & 91.79 & & & \\
8 & .34 & 3.44 & 95.23 & & & \\
9 & .27 & 2.65 & 97.89 & & & \\
10 & .21 & 2.11 & 100.00 & & & \\
\hline
\end{tabular}

Metod ekstrakcije: analiza glavnih komponenata

Tabela 4.10

Matrica komponenata

\begin{tabular}{lcc}
\hline & \multicolumn{2}{c}{ Komponenta } \\
\cline { 2 - 3 } Odmorno & 1 & 2 \\
\cline { 2 - 3 } Srecno & .51 & .55 \\
Uspešno & .83 & -.08 \\
Mocno & .63 & .05 \\
Voljeno & .56 & .04 \\
Zašticeno & .63 & -.59 \\
Energicno & .63 & -.55 \\
Veselo & .73 & .30 \\
Optimisticno & .86 & .05 \\
Vedro & .76 & .15 \\
& .84 & .09
\end{tabular}

Metod ekstrakcije: analiza glavnih komponenata 


\section{Rozenbergova skala samopoštovanja}

Tabela 4.11

Ukupna objašnjena varijansa

\begin{tabular}{lrrrrrrrrr}
\hline Komponenta & \multicolumn{9}{c}{ Svojstvene vrednosti } \\
\hline & \multicolumn{1}{c}{$\%$} & \multicolumn{1}{c}{ Kumulativni } & & $\%$ & Kumulativni & & $\%$ & Kumulativni \\
& Total & varijanse & $\%$ & Total & varijanse & $\%$ & Total & varijanse & $\%$ \\
\hline 1 & 3.71 & 37.13 & 37.13 & 3.713 & 37.13 & 37.13 & 2.74 & 27.40 & 27.404 \\
2 & 1.33 & 13.34 & 50.47 & 1.334 & 13.34 & 50.47 & 2.32 & 23.06 & 50.467 \\
3 & .96 & 9.65 & 60.12 & & & & & & \\
4 & .78 & 7.76 & 67.88 & & & & & & \\
5 & .70 & 7.03 & 74.91 & & & & & & \\
6 & .62 & 6.22 & 81.13 & & & & & & \\
7 & .61 & 6.06 & 87.19 & & & & & & \\
8 & .55 & 5.52 & 92.70 & & & & & & \\
9 & .42 & 4.15 & 96.85 & & & & & & \\
10 & .32 & 3.15 & 100.00 & & & & & & \\
\hline
\end{tabular}

Metod ekstrakcije: analiza glavnih komponenata

Tabela 4.12

Matrica komponenata

Uopšteno govoreci, zadovoljan/na sam sobom.

\begin{tabular}{cc}
\multicolumn{2}{c}{ Komponenta } \\
\hline 1 & 2 \\
\hline .63 & -.02 \\
-.54 & .43 \\
.61 & .03 \\
-.61 & .39 \\
.61 & .36 \\
-.73 & .41 \\
.57 & .07 \\
-.67 & .21 \\
.52 & .55 \\
.59 & .59
\end{tabular}

Želeo/la bih da imam više samopoštovanja.

Osecam da ima puno toga cime bih se mogao/la ponositi.

Ponekad se osecam potpuno beskorisno.

Sposoban/na sam da radim i izvršavam zadatke jednako uspešno kao i vecina drugih.

$\mathrm{S}$ vremena na vreme osecam da ništa ne vredim.

Osecam da posedujem niz vrednih osobina.

Sve više sam uveren/a u to da jako malo vredim.

Mislim da vredim barem koliko i drugi ljudi.

59

Metod ekstrakcije: analiza glavnih komponenata 


\section{Skala akademskih ambicija}

Tabela 4.13

Ukupna objašnjena varijansa

\begin{tabular}{ccccccc}
\hline Komponenta & \multicolumn{5}{c}{ Svojstvene vrednosti } \\
\cline { 2 - 6 } & Total & \% varijanse & Kumulativni \% & Total & \% varijanse & Kumulativni \% \\
\hline 1 & 1.76 & 44.04 & 44.03 & 1.76 & 44.04 & 44.04 \\
2 & .10 & 24.97 & 69.01 & & & \\
3 & .77 & 19.21 & 88.22 & & & \\
4 & .47 & 11.78 & 100.00 & & & \\
& & &
\end{tabular}

Metod ekstrakcije: analiza glavnih komponenata

Tabela 4.14

Matrica komponenata

\begin{tabular}{lc}
\hline & Komponenta \\
\cline { 2 - 2 } Stalo mi je do toga da imam dobre ocene na studijama. & 1 \\
\cline { 2 - 2 } Ne mogu sebe da zamislim da poništavam ispitnu ocenu. & .83 \\
Imam razumevanja za ljude koji se žale ako nisu zadovoljni ocenom. & -.60 \\
Dajem sve od sebe da budem odlican student. & .51 \\
\hline
\end{tabular}

Metod ekstrakcije: analiza glavnih komponenata 
Skala životnog optimizma (LOT)

Tabela 4.15

Ukupna objašnjena varijansa

\begin{tabular}{|c|c|c|c|c|c|c|c|c|c|}
\hline \multirow[t]{3}{*}{ Komponenta } & \multicolumn{6}{|c|}{ Svojstvene vrednosti } & \multirow[b]{3}{*}{ Total } & \multirow[b]{3}{*}{$\%$ varijanse } & \multirow[b]{3}{*}{ Kumulativni \% } \\
\hline & & $\%$ & & & $\%$ & & & & \\
\hline & Total & varijanse & Kumulativni \% & Total & varijanse & Kumulativni \% & & & \\
\hline 1 & 2.51 & 41.91 & 41.91 & 2.52 & 41.91 & 41.91 & 2.26 & 37.66 & 37.66 \\
\hline 2 & 1.14 & 19.03 & 60.94 & 1.14 & 19.03 & 60.94 & 1.40 & 23.28 & 60.94 \\
\hline 3 & .88 & 14.61 & 75.55 & & & & & & \\
\hline 4 & .55 & 9.22 & 84.78 & & & & & & \\
\hline 5 & .53 & 8.88 & 93.66 & & & & & & \\
\hline 6 & .38 & 6.35 & 100.00 & & & & & & \\
\hline
\end{tabular}

Metod ekstrakcije: analiza glavnih komponenata

Tabela 4.16

Matrica komponenata

\begin{tabular}{lcc}
\hline & \multicolumn{2}{c}{ Komponenta } \\
\cline { 2 - 3 } U neizvesnim vremenima obicno ocekujem najbolje. & 1 & 2 \\
\cline { 2 - 3 } Ako postoji mogucnost da mi se nešto loše desi, sigurno ce se i desiti. & .62 & .17 \\
Uvek sam optimistican/na kada je moja buducnost u pitanju. & -.67 & .20 \\
Gotovo nikada ne ocekujem da ce mi stvari "ici na ruku". & .73 & .12 \\
Retko racunam na to da ce mi se lepe stvari desiti. & -.38 & .84 \\
Na kraju krajeva, ocekujem da ce mi se dobre stvari desiti pre nego loše. & -.76 & .14
\end{tabular}

Metod ekstrakcije: analiza glavnih komponenata 